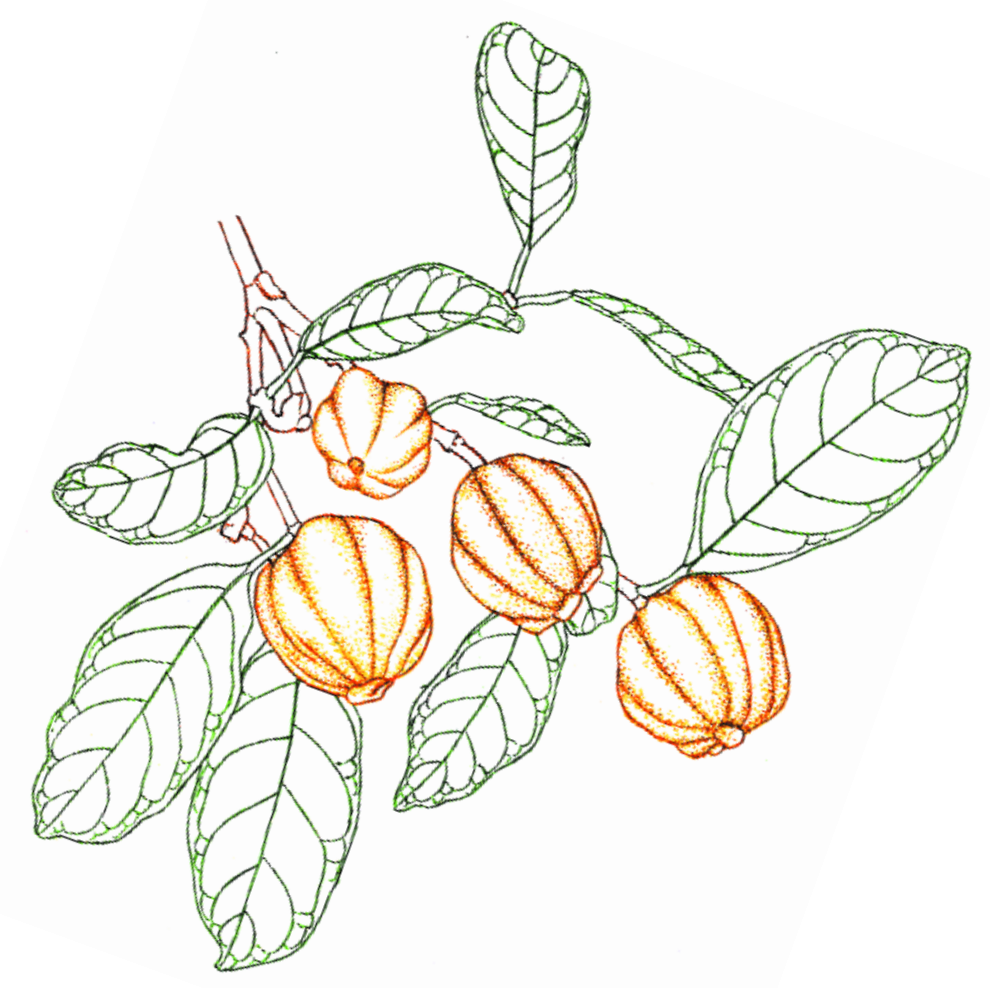

Riches of the forest:

Food, spices, crafts

and resins of Asia

Editors

Citlalli López

Patricia Shanley

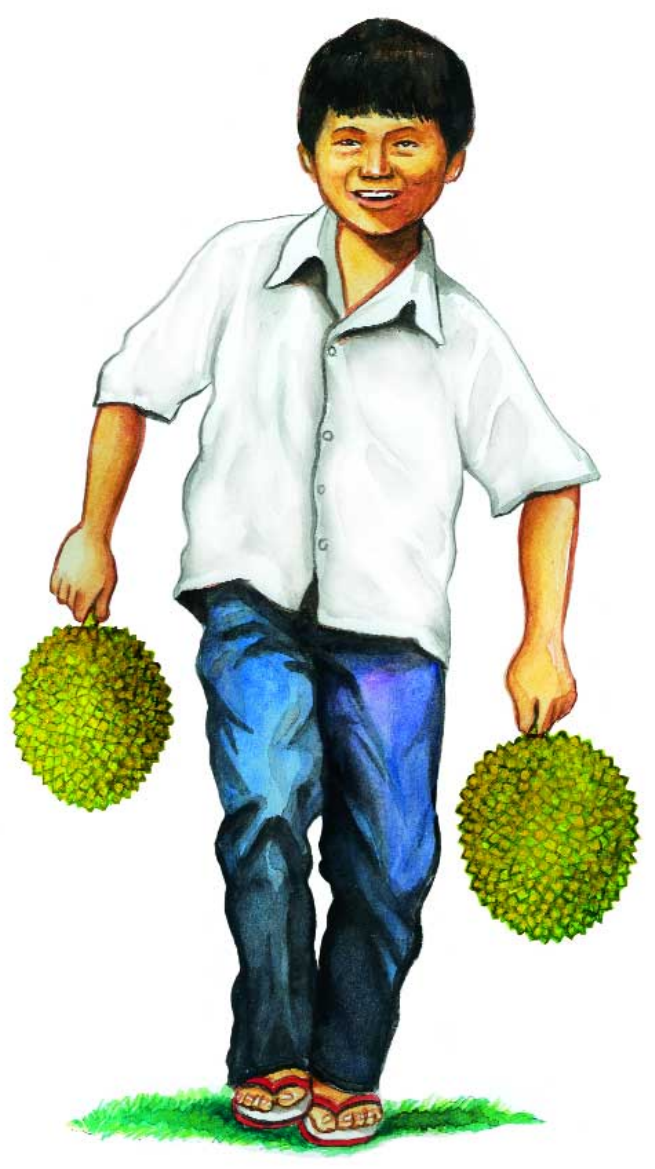




\author{
Riches of the forest: \\ Food, spices, crafts and resins of Asia
}





\title{
Riches of the forest: \\ Food, spices, crafts and resins of Asia
}

\author{
Editors
}

Citlalli López

Patricia Shanley
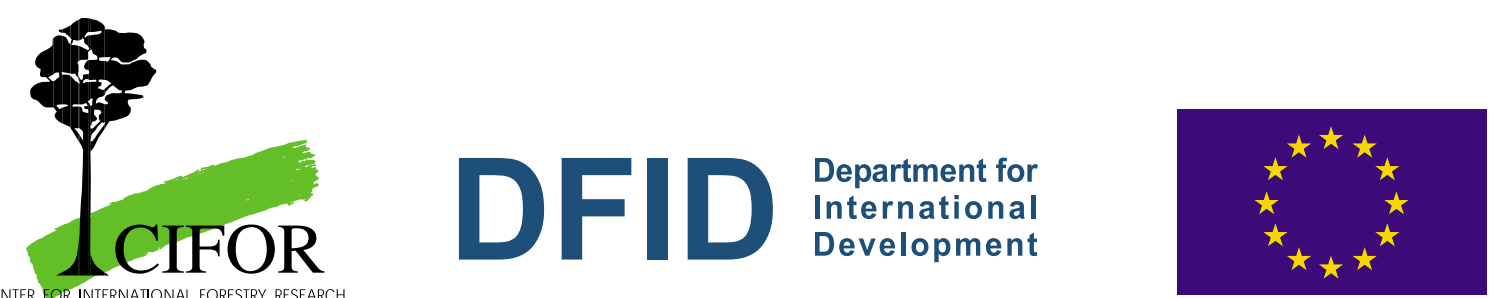
Scientific reviewer: Jenne de Beer

Reviewer and copy editor: Tess Holderness

Case study illustrations: Dadi Sungkowo

Botanical illustrations: Ishak Syamsudin

Lay-out design: Yani Saloh

Lay-out: Eko Prianto

(C) 2004 by Center for International Forestry Research

All rights reserved. Published in 2004

Printed in Desa Putra, Indonesia

ISBN 979-3361-18-2

Office address:

Jalan CIFOR, Situ Gede

Sindang Barang, Bogor Barat 16680, Indonesia

Mailing address:

P.O. Box 6596 JKPWB, Jakarta 10065, Indonesia

tel: $+62(251) 622622$

fax: $+62(251) 622100$

e-mail: cifor@cgiar.org

website: www.cifor.cgiar.org 


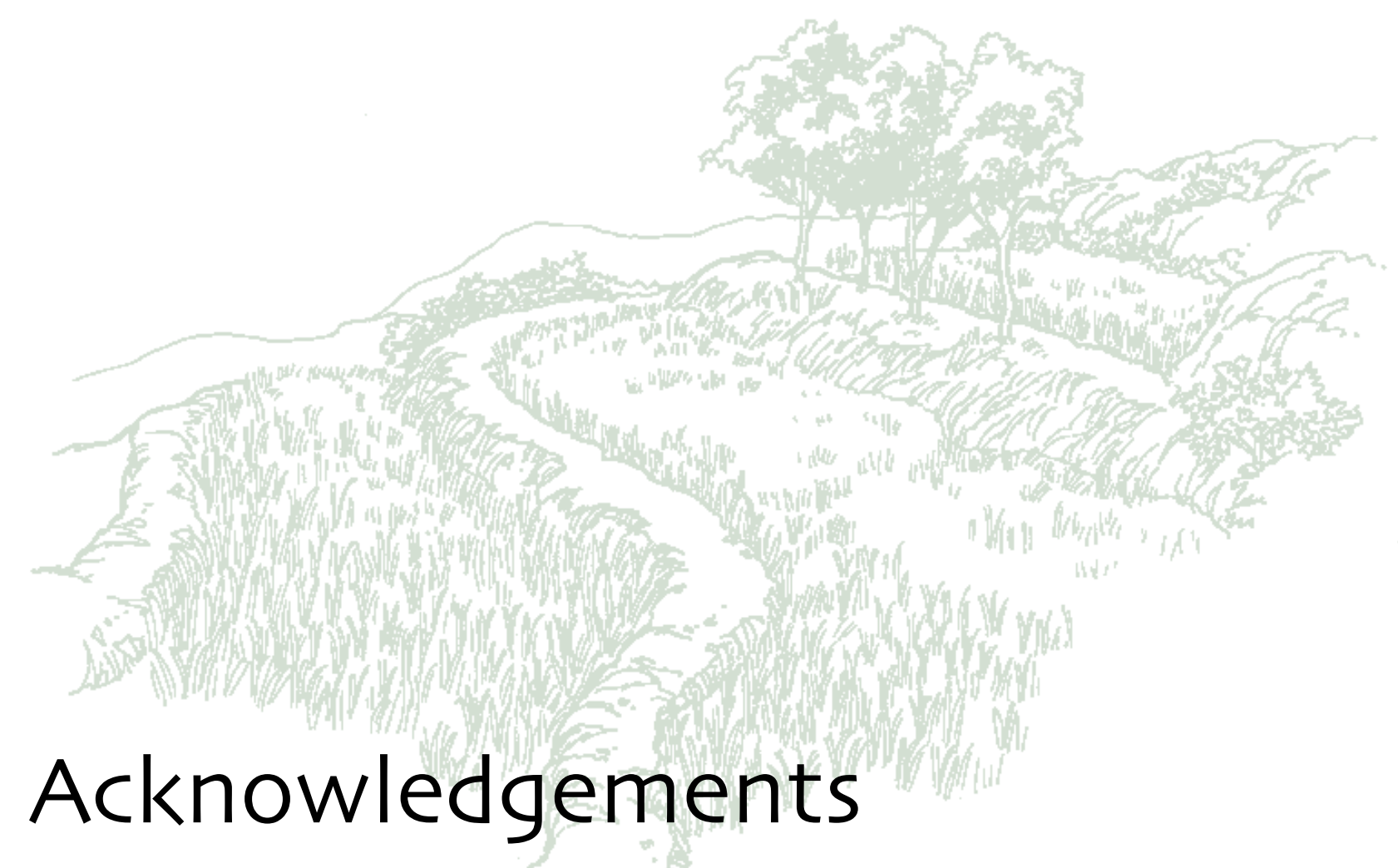

We would like to thank the restitution thematic working group, especially Alfredo Fantini, Rocío Alarcón Gallegos, Paul Hersch-Martínez and Mariana Ciavatta-Pantoja, for their catalysing role and dedication to this project. Marina Goloubinoff, Jenne De Beer, Koen Kusters, Nicolas Césard, Titin Suhartini and Ramadhani Achdiawan offered valuable assistance during the compilation of this volume. The CIFOR-Communications Unit, Information Services Group, especially Michael Hailu, Yani Saloh and Eko Prianto, also offered technical assistance and support. This book was developed as part of CIFOR's broader NTFP Case Comparison Project, led by Manuel Ruiz-Pérez and Brian Belcher, who supported this publication throughout its development. This book would not have been possible without the generous support from the UK Department for International Development (DFID) and the European Commission (EC). 


\section{Foreword}

The richness of Asia's forests is reflected in the manifold products derived from these forests for human use. To serve as a first introduction to this plethora of products is the primary objective of the book at hand.

The reader may be a city dweller, but nevertheless is likely to have first hand experience with some of the products presented in the following cases. Forest products are part of our daily lives - in the form of ingredients that we may use in our kitchens when preparing fine food, fibres and different materials in furniture and craft items around the living room, or in components of the paint and varnish on window frames and doors. If none of the former, check the cosmetics on bathroom shelves! The source of these everyday goods and the stories that go with them however, are less well known.

In the stories that are woven around forest products the following issues are covered:

- The key role which non-timber forest products (NTFPs) play in forest dependent communities

- The organisation of the trade and benefit sharing through the trade chain

- The sustainable (or unsustainable) management of resources and the link with forest conservation

Meanwhile, forest-based communities, as the primary producers, are getting increasingly organised with the aim of:

- Securing a sustainable harvest

- Improving the quality of raw or semi-processed produce

- Becoming more successful in marketing

To enhance the latter, efforts are underway to make community-based and sustainably produced NTFPs more recognisable as such, both in domestic markets, as well as overseas.

This publication, Riches of the forest: Food, spices, crafts and resins of Asia, apart from being entertaining to read, may help you as a demanding consumer, to make more informed choices while shopping around next time.

\section{Jenne de Beer}

Field Coordinator

NTFP Exchange Programme

South and Southeast Asia (EP) 


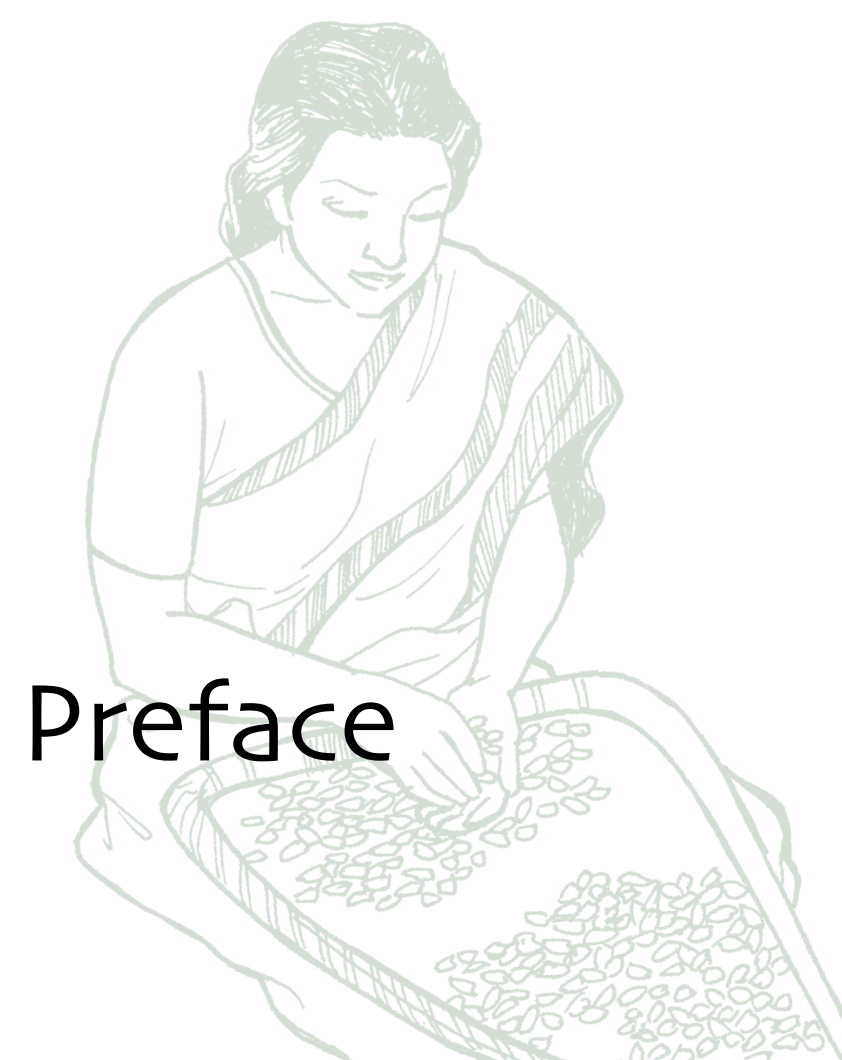

Did you ever wonder where the raw material used for manufacturing incense sticks comes from, the bark pulp used to make handmade paper, or the ingredients of certain luxury botanical products like cardamom oil and the fragrances of elegant perfumes? Within this small volume you will find the stories of various products that are linked to the forests and will learn more about the people who gather and process the raw materials to make them, in many different parts of South East Asia. The natural bounty of trees, shrubs and even insects is harvested within forests, on farmlands, in caves or along river banks. These raw materials - like fruits, nuts, bark and wood, just to name a few - are then processed and traded both locally, and to various places around the world.

South East Asia has a long history of trade in resins, oils and condiments - products that have enchanted the senses of people in Europe for generations and have enriched the lives of those both within and outside of Asia. In many cases, such trade began centuries ago and has continued until the present day, although over time, the use of some products has changed. For example, originally used for its captivating fragrance, damar resin is now used as a natural gum for industrial products such as paint. The fruit rind of uppage trees in India, traditionally used as a condiment, has found a new use as an active component in weight loss pills. Other luxury forest goods, such as sandalwood and birds' nest soup, traditionally used only by the elite classes, are nowadays enjoyed by many people throughout the world. 
Not only have the uses and users changed, but also the ways of managing, transporting and trading forest goods. Some plant and animal products such as durian, benzoin, damar and honey are now not only collected in forests but are also managed in home gardens, farms and in agroforestry systems. The modes of transporting products to market have also changed. Centuries ago, many months and years would elapse while traveling across the seas from Asia to Europe and back again. By contrast today, mushrooms collected in the morning from Chinese forests can be eaten in Japanese restaurants later that same evening. Birds' nests collected in dark, slippery caves in the far reaches of Indonesia are sold in China, and bark collected in Laos from tout tiang shrubs is found on incense sticks marketed in London shops.

The trade in various South East Asian forest products includes stories of both growth and decline. During the last two decades, steadily increasing demand for some products, such as mushrooms and woodcarvings, has been a catalyst for over-harvesting. A healthy response on the part of some collectors has been to begin planting useful species and to better manage naturally occurring populations. This is the case in Laos, for the paper mulberry tree, and in India, for cardamom and also, tendu leaves for wrapping cigarettes. In such instances, harvesters are working to ensure that there will be a constant and secure supply to meet future needs.

From their point of collection until their arrival in shops, where consumers buy them, forest goods pass through many hard-working hands. Of all the beneficiaries, the harvesters of forest resources usually obtain the least financial return. However, for many people living in or near the forests, the cash return is only one of a wide range of benefits obtained from forests. Many of the products that they gather on a regular basis for their families (such as forest fruits, honey and rattan), also provide essential sources of food, medicine and shelter. In spite of modern marketing and processing, many people throughout the world continue to collect plants directly from nature for free.

The next time you taste a spicy dish, sip aromatic tea or whiff the smoke of a kretak cigarette, recall the people and the forests which have helped to make these products and pleasures a possibility. 


\section{Table of contents}

Acknowledgements

Foreword

Preface

Map of Asian cases and locations

\section{Introduction: Setting the scene}

\section{Fruits / Seeds}

Uppage, fruit rind - Nitin Rai

Lapsi, fruit snacks - Krishna H. Gautam

Cardamom spice - T.K. Raghavan Nair \& M. Govindan Kutty

Cardamom seeds - Catherine Aubertin

Durian - Marina Goloubinoff \& Renni S. Hoshi

\section{Mushrooms}

Song rong mushroom - Ying Long Chen 


\section{Birds / Insects}

Swiftlets, edible birds' nests - Marina Goloubinoff

Kroto, ant larvae and pupae - Nicolas Césard \& Irdez Azhar

Honey bee, honey and related products - Jenne de Beer 41

\section{Shoots / Culms / Stems}

Bamboo, various products - Fu Maoyi \& An Van Bay

\section{Leaves / Wood / Bark}

Tendu, leaves for cigarettes - Arvind A. Boaz

\section{Resin / Oil}

Benzoin resin - Carmen García Fernández

Sandalwood, oil and handicrafts - Dede Rohadi \& Retno Maryani 81

Damar resin - Hubert de Foresta \& Geneviève Michon $\quad 85$

Conclusions: The lessons learned 89

References $\quad 96$

Glossary $\quad 104$

$\begin{array}{ll}\text { Authors' contact details } & 109\end{array}$

$\begin{array}{ll}\text { Source material used for the illustrations } & 115\end{array}$ 


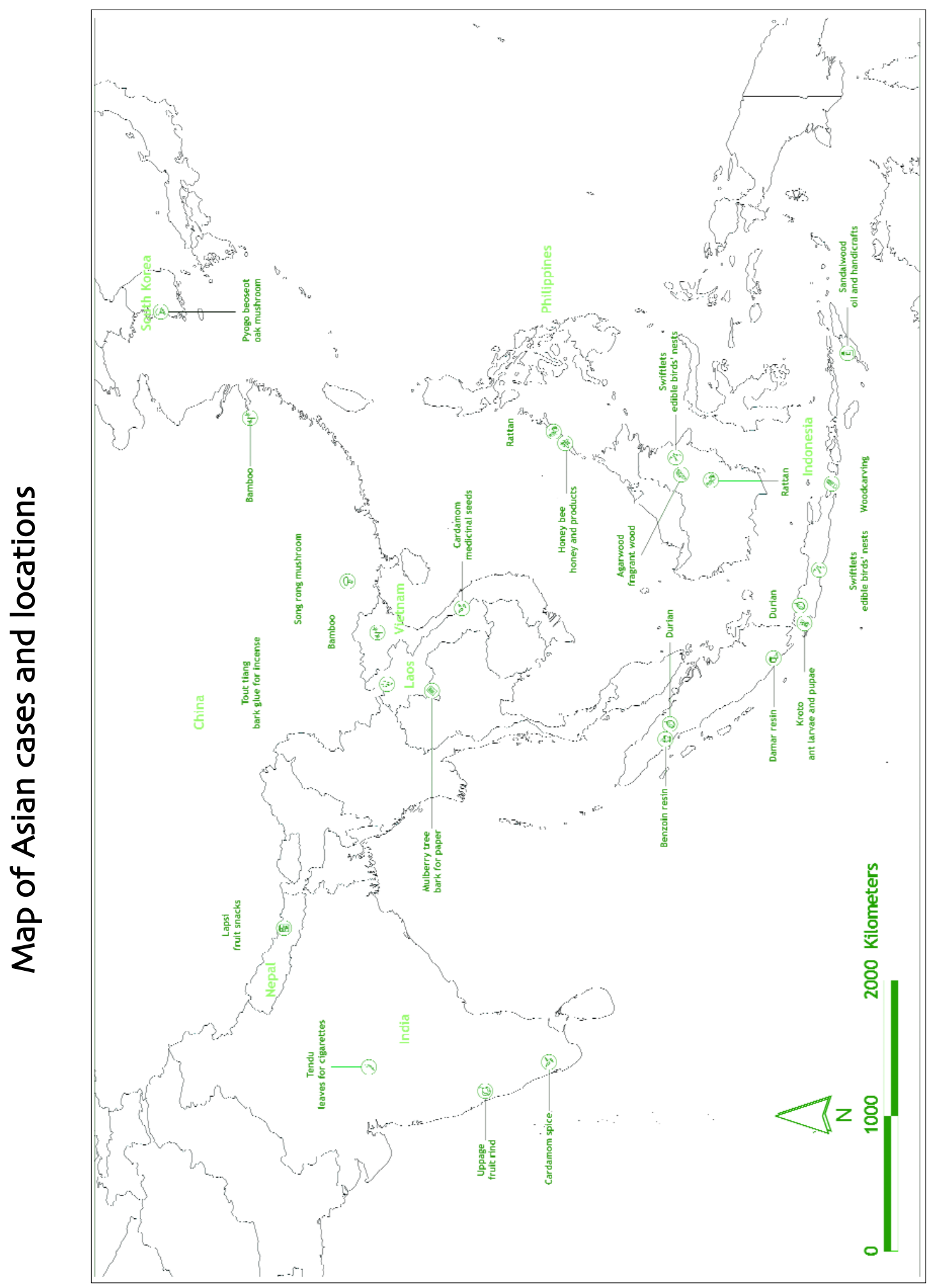

xii 


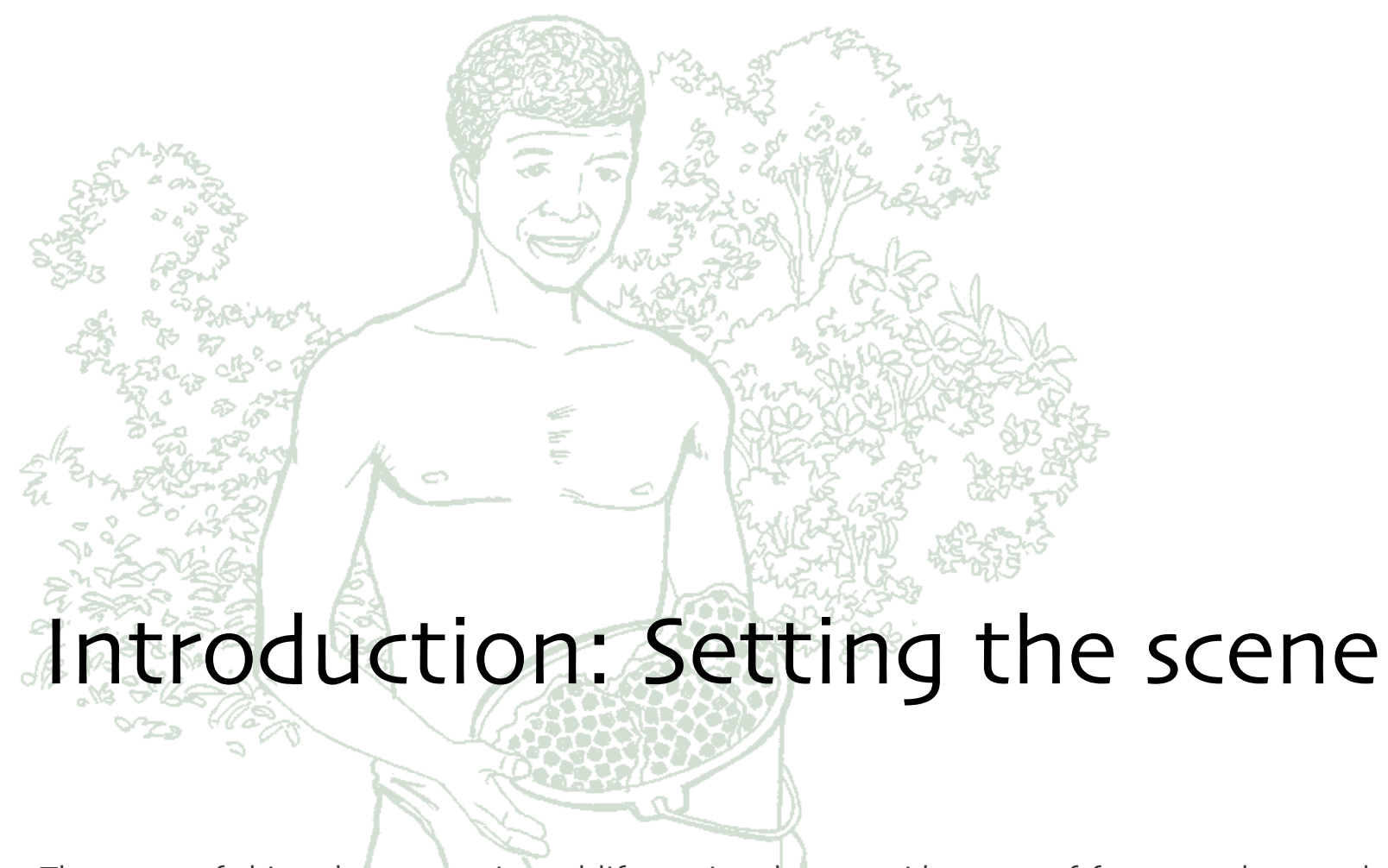

The pages of this volume contain real life stories about a wide range of forest products and the people who use and manage them. The individual chapters illustrate how different forest foods, fibres, medicines and resins are grown, harvested, processed and traded. Through these stories, we learn about the history of such products - some of which have been used and traded for centuries and some of which are relatively new. We also find out about the various opportunities and problems that collectors and traders face, and the way they respond to change.

The group of goods called non-timber forest products (NTFPs) includes a great variety of forest resources, used for both domestic and commercial purposes. Centuries ago, Chinese and middleeastern traders would cross seas, mountains and deserts in search of forest spices and resins. Later, during the colonial period, there was great interest in Europe in the many valuable foods and spices that can be sourced from forests. Voyages of exploration, sometimes lasting a year or more, were launched to seek new flavourings and preservatives for European markets. After the Second World War however, a shift occurred and forests began to be valued principally for their timber resources and for wood fibre for paper-making. At the same time, commercial and scientific interest in other forest products waned.

Beginning in the 1980s, recognition of the rapid rates of deforestation, and a newfound appreciation of the difficulties facing people living in rural areas, led to a renewed focus on forest products other than timber. Researchers began assessing both the commercial and subsistence roles of these products. Studies carried out in Latin America compared potential income from a variety of forest products (like fruits, medicinal plants and fibres) with the possible income from logging 
and other land uses, concluding that over the long term, NTFPs could potentially provide more value. Some aspects of the early studies have since been criticised on economic grounds, however the research has served to create a wave of interest in NTFPs, and this has led to an increased appreciation of their overall importance for people in both forest communities and cities.

During the last 15 years, governmental and non-governmental organisations (NGOs) have given their attention and support to various NTFP-related activities, with the aim of improving the livelihoods of families living in and near forests. Some of these initiatives have been effective in achieving social, economic or conservation goals. However, overall results have been mixed, partly due to the great diversity of conditions and the different circumstances in which forest resources are harvested, processed and traded.

\section{Sharing knowledge about forest products}

Many researchers have studied forest products in different parts of the world, using methods from various disciplines, including biology, economics and anthropology. While these studies have increased our knowledge about forest resources, they have also raised important new questions. Due to the widely differing methods used however, it has been difficult to compare the studies and draw general lessons. To overcome this problem, a group of researchers from around the world recently combined efforts to compare and contrast individual case studies. This collaborative research project, coordinated by the Center for International Forestry Research (CIFOR), with major funding from the UK Department for International Development (DFID), included 61 different cases of forest product commercialisation from Asia, Africa and Latin America. CIFOR worked with small teams and individual researchers, representing 47 NGOs, universities and government research agencies, from 27 different countries. The researchers - which included ecologists, foresters, agronomists and anthropologists - wanted to gain a better understanding about the wide range of conditions that influence whether NTFP trade benefits rural people and helps to conserve forests and natural resources, and if so, how. With improved knowledge about the impacts of commercial trade on forest products and people, the researchers now hope to share this information about rural development and natural resource conservation with decision makers in government and development agencies.

An in-depth, three volume set of scientific reports has been published, focusing on the three regions of Asia, Africa and Latin America - Forest products, livelihoods and conservation: Case-studies of NTFP systems. The researchers were also keen to share their knowledge about forest resources with a more general audience, beyond scientists and donors, using simpler language and an illustrated, briefer format. To achieve this goal, three supplementary volumes have been produced: Riches of the forest - Food, spices, crafts and resins of Asia; Riches of the forest - For health, life and spirit in Africa; and Riches of the forest - Fruits, oils, remedies and handicrafts in Latin America. 
The volume in your hands is one of the products of the researchers' collaborative efforts. The 26 researchers involved in the Asian case studies explain how a selection of forest resources are harvested, processed and traded. Consumers generally go to markets, stores and bazaars, choosing and buying food and goods like decorative or beauty products without knowing much, if anything, about the history of these products or the people involved in their collection and sale. This comes at a time when forest cover worldwide is decreasing rapidly, and forest-reliant communities are having to respond to enormous changes. What can we learn from people who carve out a living harvesting forest products? And how can our buying patterns affect or assist them?

\section{The case studies}

This volume brings to life 20 case studies featuring forest plants, animals and fungi. The botanical cases are presented according to the main part of the plant being used - the fruit, bark or resin. Sometimes the plants have multiple uses, or different cultures may use the same part of a particular plant in different ways. Animals and animal products that require forest habitat are also critical for rural livelihoods, and are represented in this volume by edible birds' nests and insect larvae. In each case, the contributors describe the main characteristics of the forest product, its historical usage, harvesting and management, and how it is processed and traded. In closing, each author comments briefly on trends and current issues regarding the resource. The final chapter reviews common themes and lessons that can be drawn from these cases.

* Throughout the following cases, the symbol * denotes words for which definitions can be found in the glossary, at the end of the book.

* At the start of each case, you will notice the scientific names of the different forest plants (and animals) that are profiled. A full explanation about the use of botanical and scientific names can also be found in the glossary. 



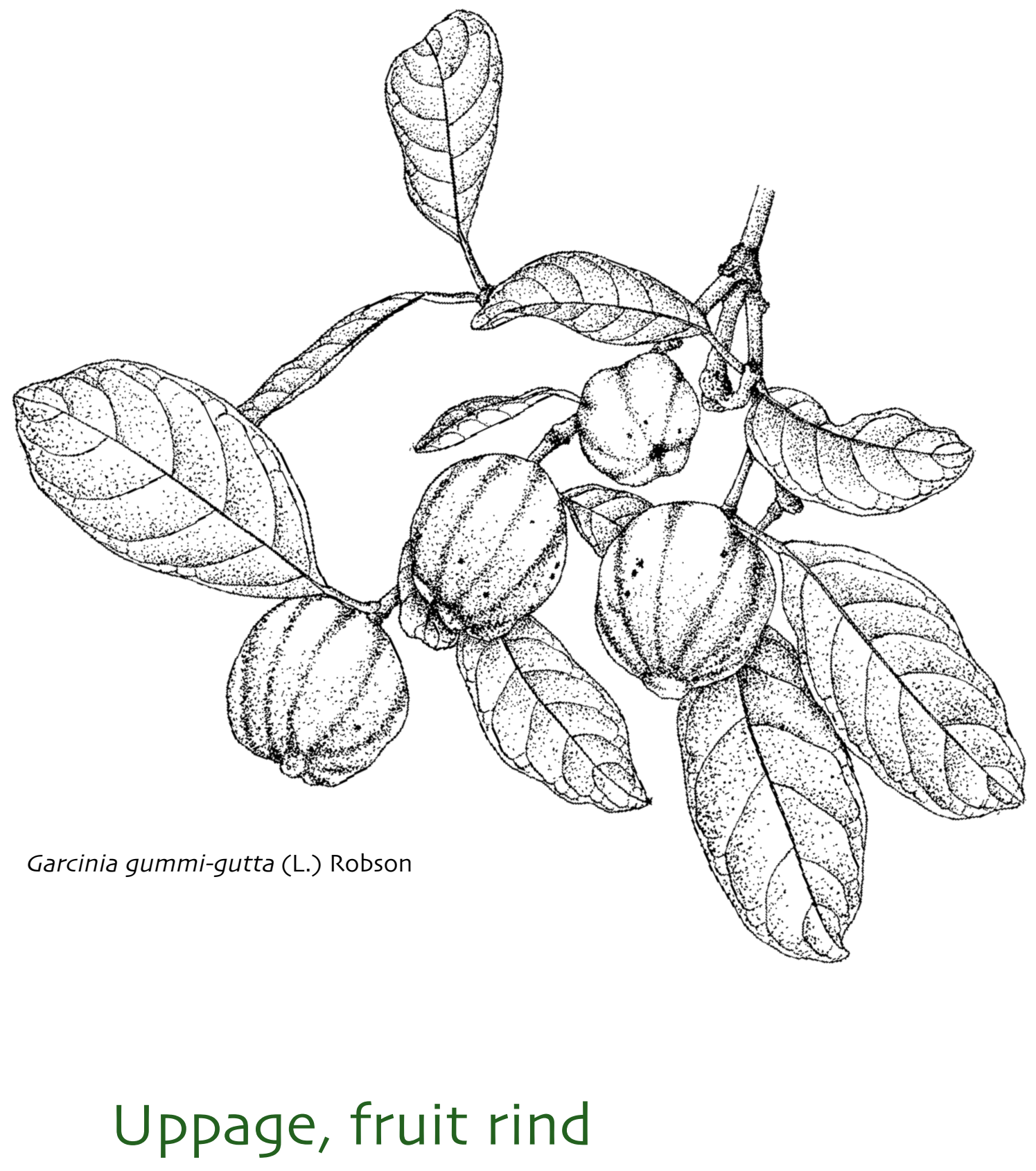

Indian case by Nitin Rai 


\section{Uppage: A fruit for forest animals, savoury dishes and weight loss programmes}

'Uppage' (Garcinia gummi-gutta) is the Kannada name for a rain forest tree that grows in the Western Ghats of South India and in Sri Lanka. For hundreds of years the rind obtained from the fruit has been used to flavour fish and pork dishes in India and Sri Lanka. In the late 1980s, scientists discovered that the rind contains a compound called Hydroxy-citric acid (HCA), which was widely believed to facilitate weight loss in humans. The product soon found a market in Europe and the United States of America, resulting in a steep rise in the price of the rind from its main source area, the Uttara Kannada district of India. However, the joy of increased profits for collectors and traders was short lived. In 1998, it was revealed that the drug was not as effective in reducing weight as first claimed. As a

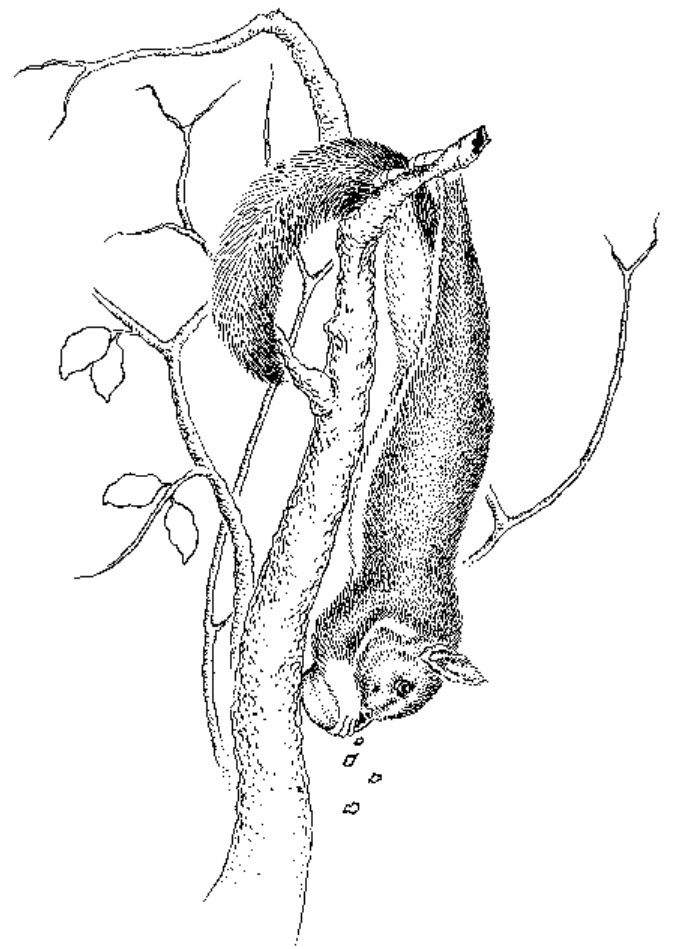

result, demand steadily fell and with it fell the price of rind, to around US\$ 0.59, where it has remained for some time. The principal market for uppage shifted back to the state of Kerala in southern India, where it has long been sold as a traditional spice.

\section{Uppage - fruit of the forest}

Uppage trees grow to about $18 \mathrm{~m}$ in height, and often occur beneath the forest canopy*. The aromatic flowers, which open at dusk, are pollinated by weevils. Only the female trees produce fruit, bearing an average of 1500 fruits, with each fist-sized fruit weighing about $75 \mathrm{gm}$ when fully ripened. The density of trees varies considerably. While some forest patches might have no uppage trees, others might have as many as 120 trees over a 1 hectare area.

Local farmers observe that some squirrels (like the Malabar giant squirrel) are unusually fat after the rains, having feasted on the uppage seeds. As few other tree species are fruiting at this time, monkeys, squirrels and civets are quite dependent upon this resource. 


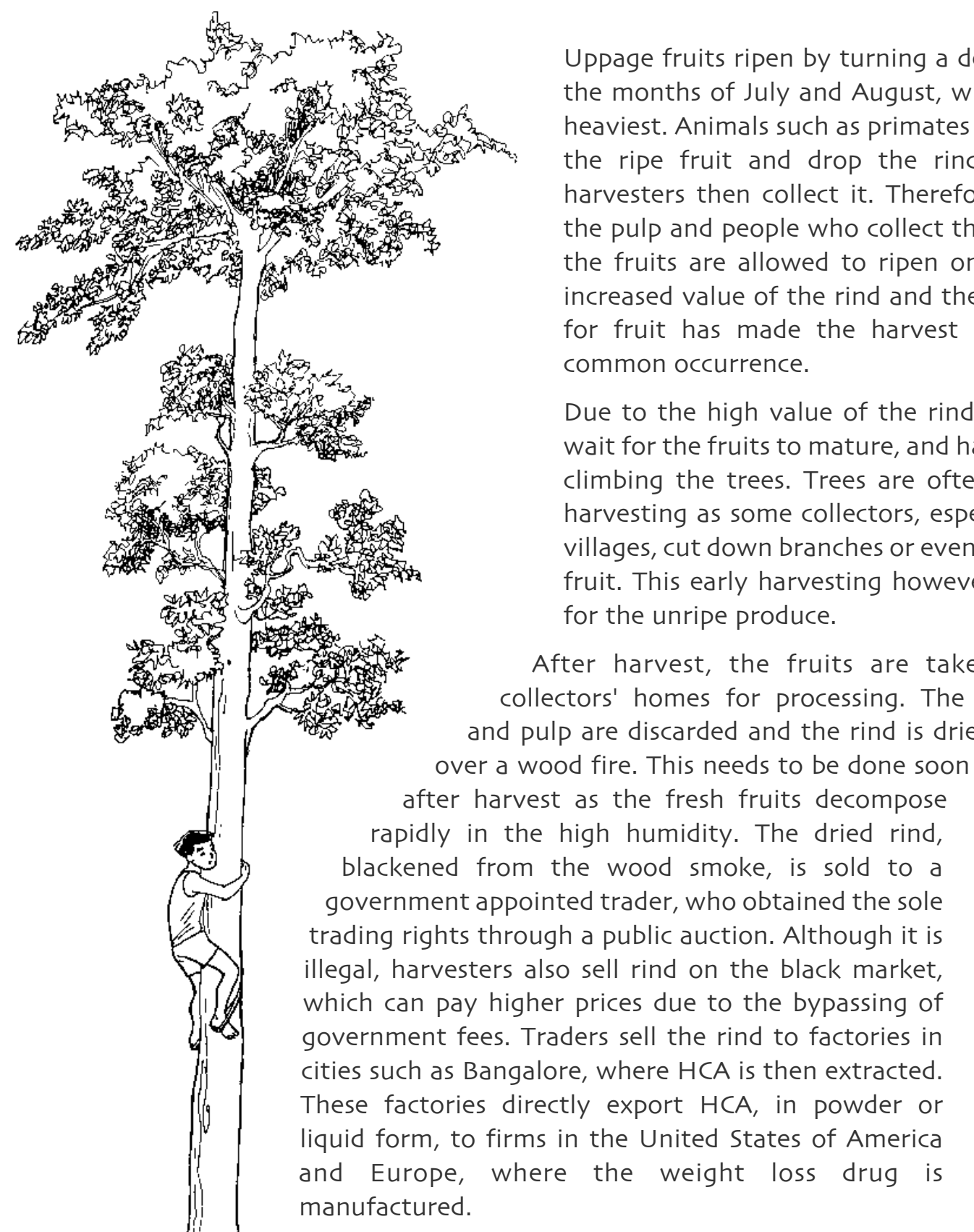
and pulp are discarded and the rind is dried over a wood fire. This needs to be done soon after harvest as the fresh fruits decompose rapidly in the high humidity. The dried rind, government appointed trader, who obtained the sole trading rights through a public auction. Although it is illegal, harvesters also sell rind on the black market, which can pay higher prices due to the bypassing of government fees. Traders sell the rind to factories in cities such as Bangalore, where HCA is then extracted. These factories directly export HCA, in powder or liquid form, to firms in the United States of America and Europe, where the weight loss drug is

Uppage fruits ripen by turning a deep yellow colour, during the months of July and August, when the rains are at their heaviest. Animals such as primates and civets eat the pulp of the ripe fruit and drop the rind to the ground, where harvesters then collect it. Therefore, animals that feed on the pulp and people who collect the rind can both benefit if the fruits are allowed to ripen on the tree. However, the increased value of the rind and the subsequent competition for fruit has made the harvest of unripe fruits a more

Due to the high value of the rind, most harvesters do not harvest the unripe fruits by fruit. This early harvesting however, results in lower prices

After harvest, the fruits are taken to the

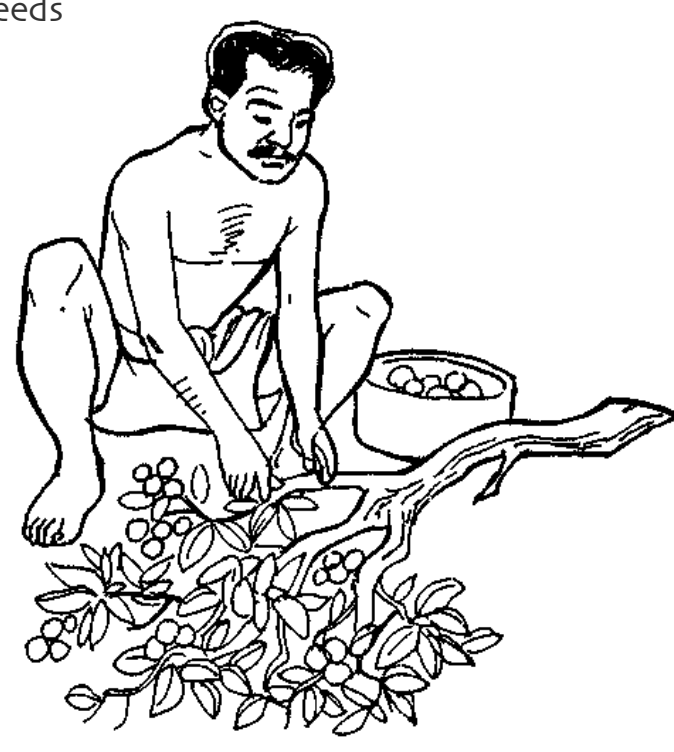

Sometimes branches or even entire trees are cut down to collect the fruit. 


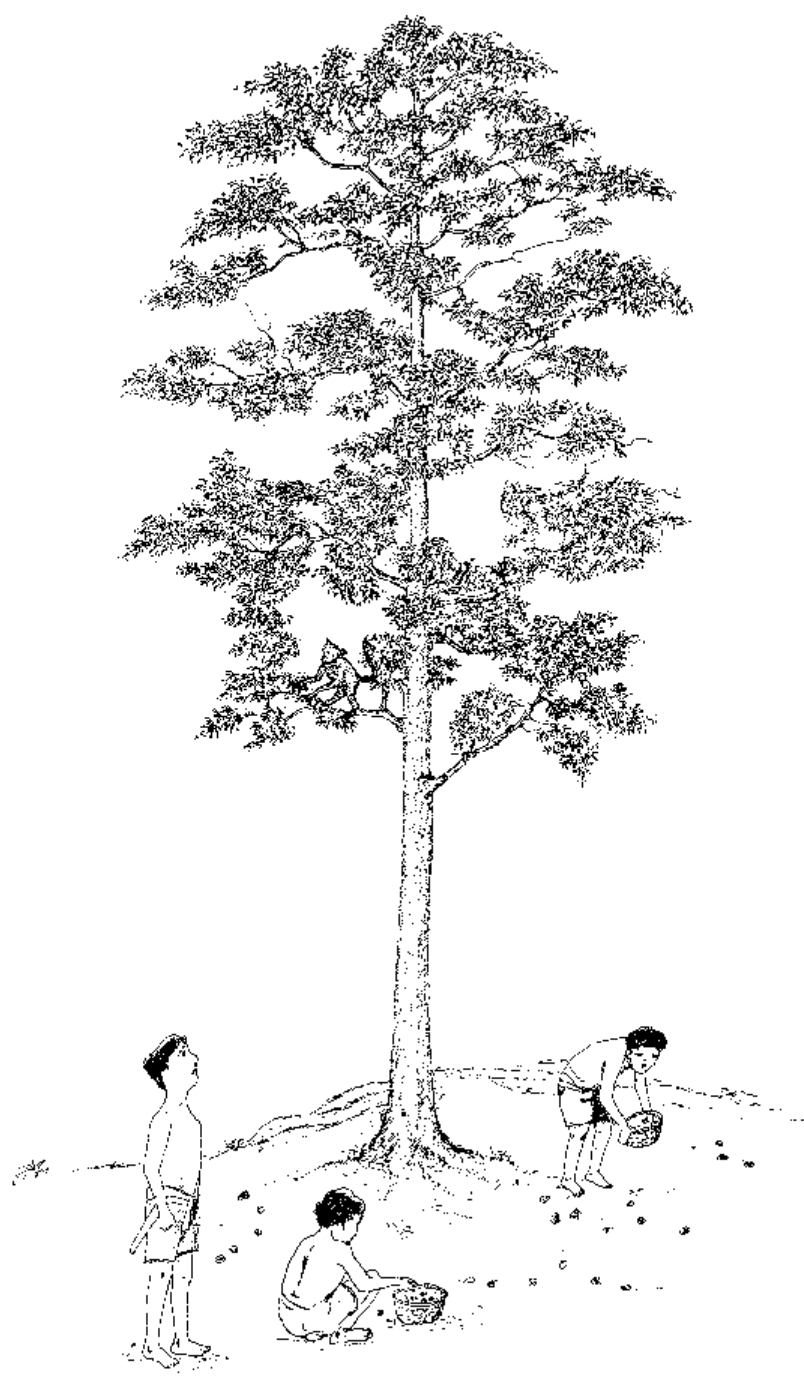

Trees, animals and people all have quite distinct usages for the seeds, pulp and rind of uppage fruits. When people respect these varying biological uses, all needs can be fulfilled compatibly.

\section{Trade fluctuations and ecological effects}

The uppage case reflects such issues as the 'green wave' in natural medicine, the obsession with looking slimmer, and the ecological effects of the lack of local control over forest resources. Transitory international markets can have a big impact on the local economy of harvesters and processors of forest products. The international market for HCA catalysed the over-harvesting of uppage fruits. As uppage trees occur in government controlled forests, harvesters show little concern for the trees during harvest, especially if collectors come from distant villages.

Where harvesters have security of access to uppage trees, fruits are generally harvested after they ripen. Thus, giving local people some level of control and security of access over forest trees will provide an incentive for harvesters to wait for the fruits to ripen. This in turn, will increase income and reduce destructive harvesting practices. With some management and monitoring, the species could be sustainably harvested". For example, delaying the date of fruit harvest will ensure that monkeys consume the fruit and disperse the seeds. This allows for the continued regeneration of the species without sacrificing income. Monkeys and people could thus work in tandem to ensure that uppage trees persist in the forest for the benefit of all. 


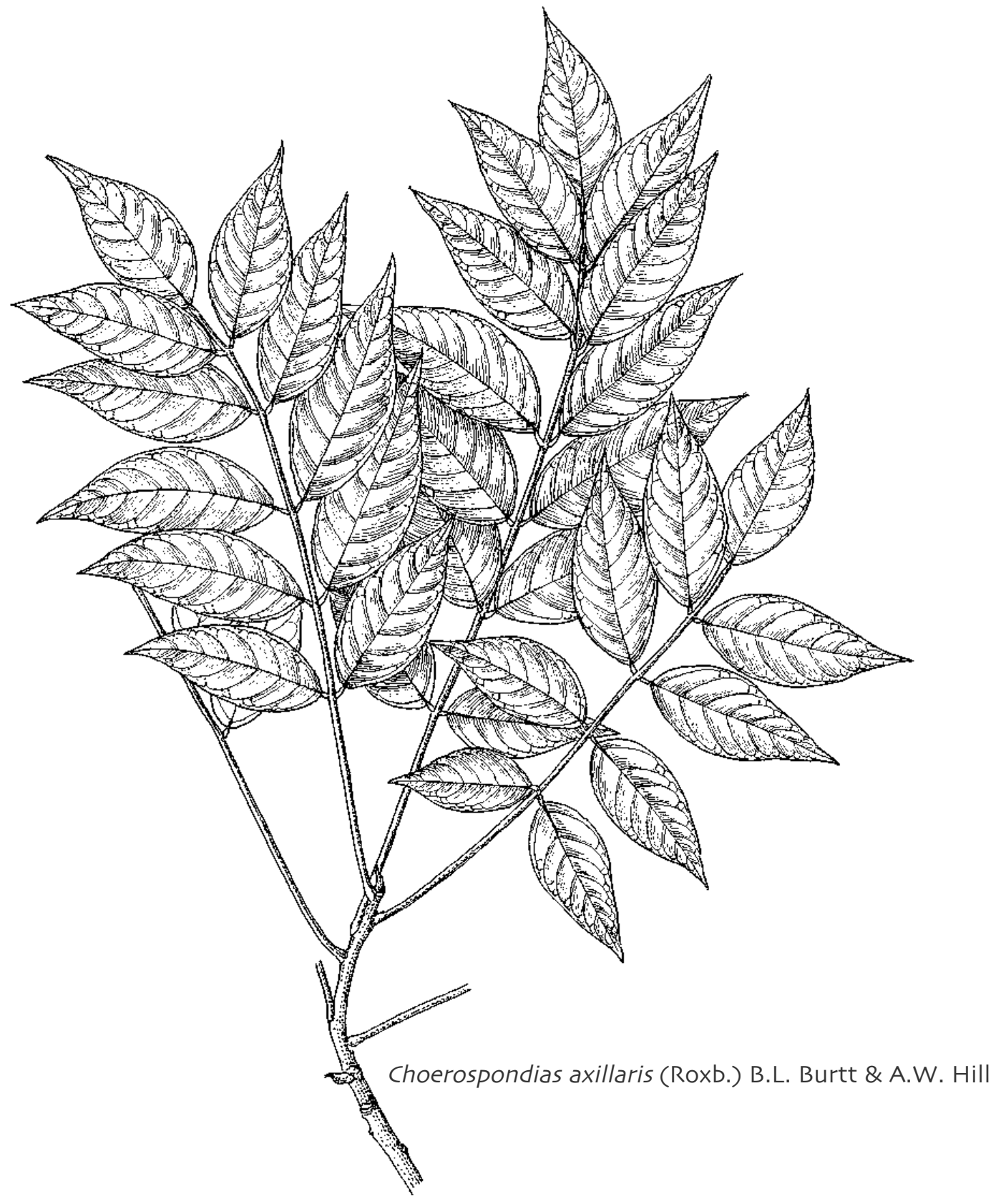

\section{Lapsi, fruit snacks}

Nepalese case by Krishna H. Gautam 


\section{Lapsi: From sour pickles to sweet 'trekker's candy'}

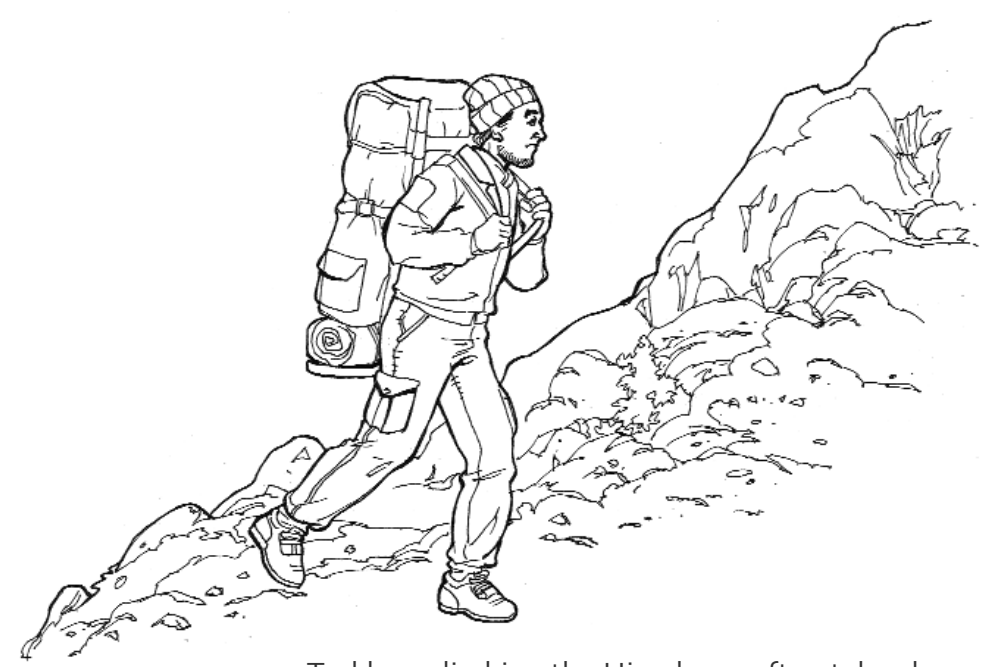

Trekkers climbing the Himalayas often take along lapsi sweets as a good source of energy - hence the name 'trekker's candy'. Meanwhile, in the hotels and restaurants of Kathmandu, tourists discover another use for the fruit, with the dried and ground skin being used as a sour topping in a range of dishes.
The sweet and sour tale of 'lapsi', as it is known in Nepal, is the tale of a versatile fruit tree - the source of products ranging from fresh fruits, to pickles, timber, 'trekker's candy' and even a type of fuel, derived from the seeds. Choerospondias axillaris, as it is known scientifically, is a tree native to the middle hills of $\mathrm{Nepal}$, in the Himalayan range (and also found in Thailand, Vietnam and (hina). Traditionally popular in rural areas for its timber and pickled fruit, it has found a new market over the past few decades amongst urban populations, tourists and foreigners. The broadening of this humble fruit's appeal has resulted in a growing local market for lapsi products and steps are now underway to further its domestication* and commercialisation*. Samples have also been trialled in Germany and Denmark to assess their export potential, which appears quite promising.

Lapsi is mentioned in various Hindu documents and its fruits are used in many rituals, for example, as an offering to the Gods. Lapsi trees are maintained in the grounds of many temples in the Kathmandu valley, where their fruits are particularly important to the survival of local monkeys and birds. These fairly large fruit trees are also found growing naturally within forests and across Nepalese farmland. In recent years, as the demand for lapsi products has grown, so too has the demand for seedlings to increase farmland stocks.

\section{Fresh produce and value added products}

Fruiting normally starts in the seventh year after planting and can still be observed in trees more than a century old. The trees fruit each year, although the quantity can vary, with harvesting taking place from September through to January. Although unripe fruits are used for some products, only the fully ripened ones are picked for making candy. 
Some people harvest the fruits from public forests to trade but many families grow lapsi on their own land, with the sale of fruit providing one of their main sources of regular cash income. The average annual earnings from the sale of lapsi fruit in 1996 were around US\$ 14.30 per tree or US\$ 0.06 per $\mathrm{kg}$. Normally, local porters are engaged to transport the fruits from growers to the main road, where trucks then carry the goods further on to processing units or markets.

Some of the growers also undertake small scale processing activities, which are fairly simple, have high returns and do not demand large investments. Boiling the fruit is the first step in making either candy or 'manda' (a dried mixture of lapsi pulp and salt, which is used as a snack or to make pickles). After boiling, manda producers remove the seeds, mixing the remaining pulp and fruit skin together and adding salt in the final stage to produce the sour manda. Preparation of the pulp is often done by hand although a few producers use machines. As the pulp can be stored for quite a long time in underground pits or polythene drums, processing can continue well beyond the fruiting season.

The producers of lapsi candy manually separate the skin and seeds, using only the pulp to create this special treat. The leftover skin can be sold separately for processing into ground powder, while the seeds can be sold as a type of fuel, mainly used in brick kilns. In the final stages of processing, sugar is added to the pulp to make it sweet and this mixture is then spread out in the sun to dry and harden. Tempted to try

some? In Kathmandu, lapsi products can be found in many grocery stores and sweet shops but if you want to sample the fresh fruit, the best place to look is the outdoor food markets.

Lapsi can be found growing in forests, around religious sites and on farms. It is common in hilly landscapes, on both slopes and terraces and in addition to supplying fruit, serves as a source of timber and a good natural barrier to combat landslides.

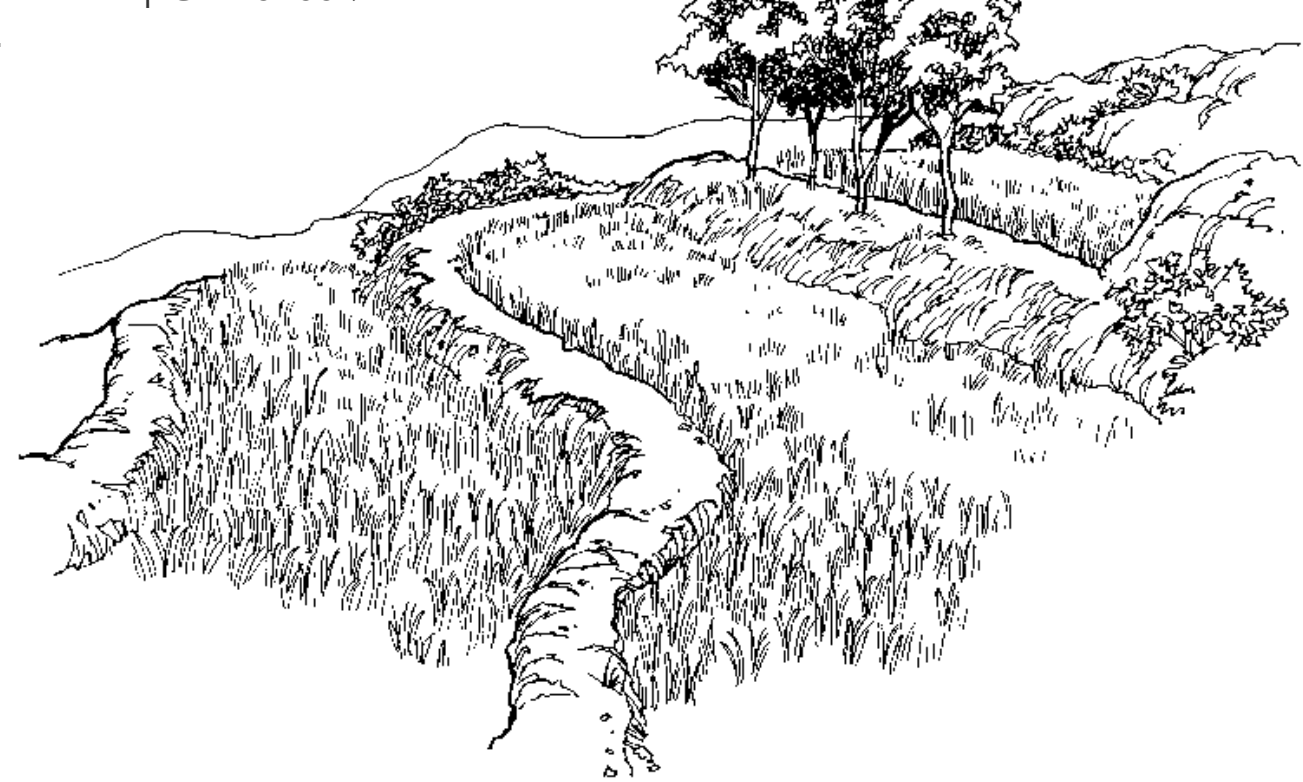




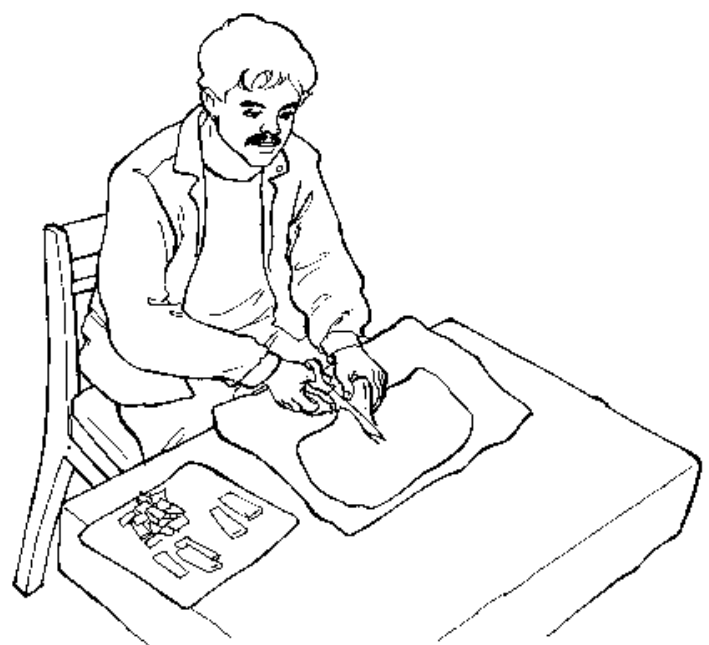

After drying in the sun, the lapsi candy is cut into square pieces before being packed in preparation for trading.

\section{Trends and issues}

The commercialisation of lapsi in the rapidly expanding Kathmandu valley has motivated people in adjoining districts to manage and harvest their own trees and to plant more. Growing lapsi involves protecting new plants, which arise from natural regeneration, or planting nursery seedlings, raised from seed. Given the growing market for products and the significant rise in plantings on private land, the forestry department in Nepal is producing seedlings for both private plantations and community forestry initiatives. The leasehold and community forest plantings ensure that poorer farmers are not excluded from the business opportunities that surround lapsi growing and harvesting.

Lapsi trees have quite an important role in agroforestry*, and in watershed conservation. One of the main challenges for farmers though, is how to best select female or fruit bearing trees. Growers have developed their own techniques for identifying male and female trees but they normally have to wait until the females start to flower - which can take seven years or so! The recognition and documentation of farmers' knowledge, combined with further study, could help address this and other issues. Earlier identification could provide more investment security for farmers, particularly since a long term perspective is required. Another issue is that the traders currently gain the largest share of profits. If farmers were to join forces and establish co-operatives and associations, they might well improve their share of the profits from this promising tree. 


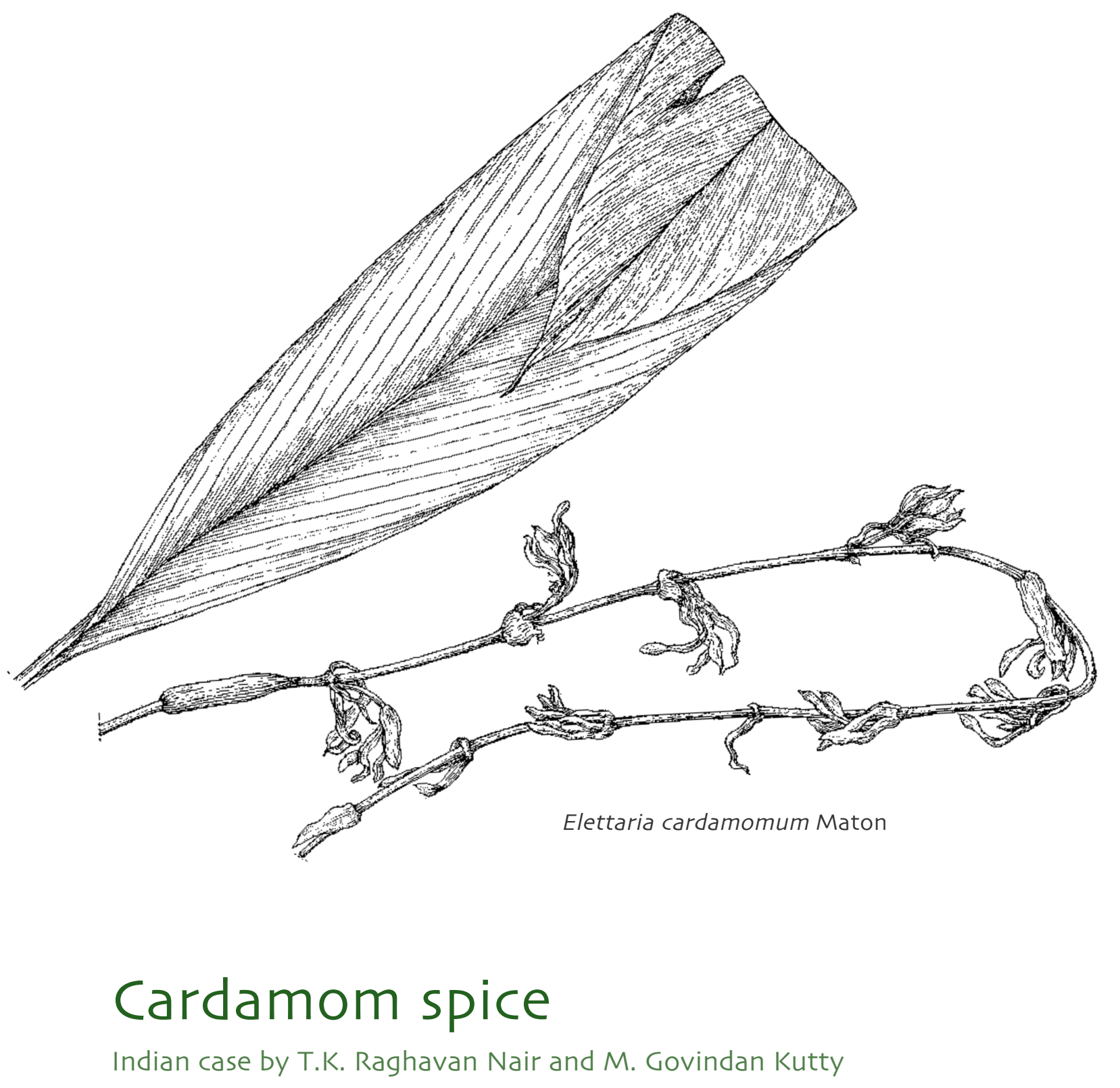




\section{Cardamom: 'Queen of Spices'}

Ahh ... Its aroma is inviting!

Mmm ... A wonderful taste, with a hint of spice!

Yes - This is tea flavoured with cardamom from India, the 'Home of Spices'.

For over 3000 years, the fruits of small cardamom (Elettaria cardamomum) have lent their special flavour and spicy taste to beverages, sweets and a whole host of foods. Throughout the world, cardamom oils and powders are also widely used in medicine and perfumery, making cardamom one of the most successful products to ever come out of the forests. A relatively eco-friendly product, cardamom requires high financial and labour inputs but it does offer good productivity and lucrative net returns.

In terms of production and trade, cardamom is India's most important spice, valued at more than US\$ 100 million in 1998. At that time, $1 \mathrm{~kg}$ of cardamom fetched US\$ 12.28 but by 2002 , the price had climbed to an impressive US\$ 18.78 per $\mathrm{kg}$. Few other forest products command such a price. Almost $90 \%$ of the harvest is consumed within India and the remainder is exported as fruits, seeds and oil to more than 40 countries, with the United Arab Emirates and Saudi Arabia being the two main destinations.

Cardamom, known as the 'Queen of Spices', is native to India (Western Ghats) and Sri Lanka, growing in moist tropical forests at elevations of $600-1500 \mathrm{~m}$. Commercial cardamom is planted in disturbed primary forests*, where it grows well in fertile soils, under a cover of filtered light from the forest canopy*, and in more intensive plantations. The main 'cardamom zone' lies across the Indian states of Kerala, Karnataka and Tamil Nadu. Market opportunities and suitable growing conditions have also led to the introduction of this cardamom species into Guatemala (the biggest producer outside India), Tanzania, El Salvador, Vietnam, Cambodia, Papua New Guinea and Laos.

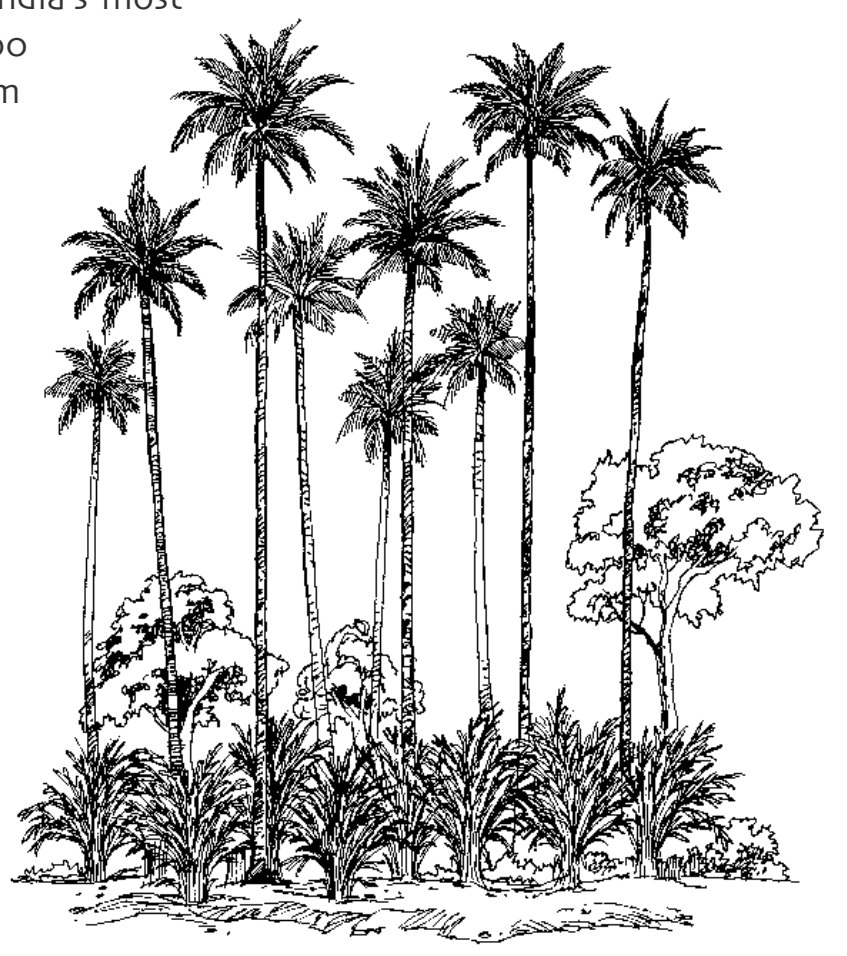

Cardamom is a perennial* plant that grows $3-5 \mathrm{~m}$ tall, in clumps, and has long, narrow leaves. Individual plants can be harvested commercially for $10-12$ years and in private plantations, can often be found under areca nut palms or rubber trees, or mixed in with coffee and pepper vines. 


\section{From planting to processing}

The easiest and most effective cultivation method is via tillers (underground stems with aerial shoots) collected from mother plants with desirable qualities. In preparation, the men dig pits while the women do the planting, during the monsoon season. These plants must then be kept free from weeds, pests and diseases. Applying manure ensures a better yield and although fertilisers, fungicides and pesticides are often used in production, organic" cardamom obtains a better price.

Annually, a number of slender flowering stalks (spikes) appear from March to April, each more than $1 \mathrm{~m}$ long and bearing 80-120 white and violet striped flowers. With bees as the pollinators, farmers can often earn additional income from beekeeping and the sale of honey and related products. After flowering, small, ovoid fruits or berries appear, containing many little, round dark seeds, covered by a thin layer of pulp and a

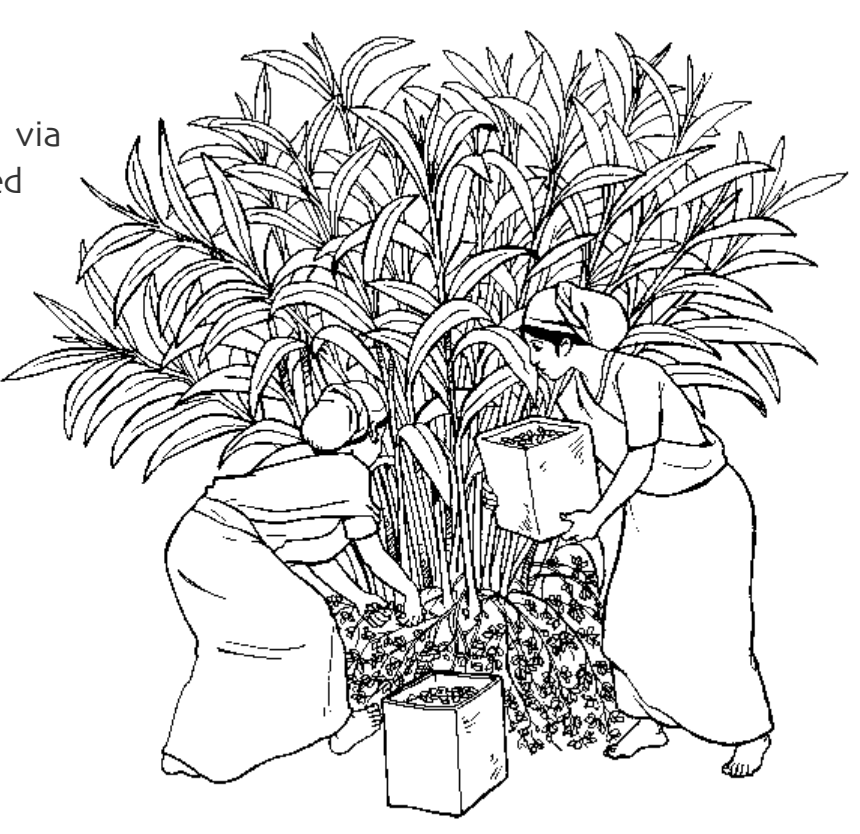

With women taking charge of most of the work, except for trimming branches and pitting and scrubbing the seeds, the 'Queen of Spices' is appropriately named!

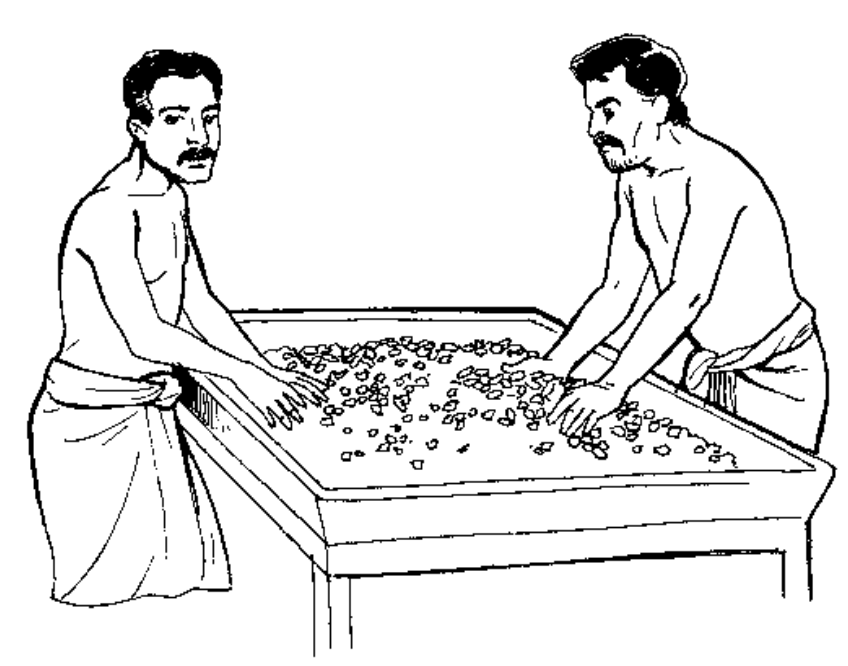

Cardamom production calls for significant financial investment and is very labour intensive. It involves trimming overhanging tree branches (to regulate the shade under which the plants grow), collecting high quality tillers, planting, applying manure and pesticides, weeding, forking (raking the soil to promote better root growth) and in intensively managed areas, irrigation.

Green berries are collected continuously as they mature, from May to December and are cured or dried before they deteriorate. This is done in multi-chambered dryers (using firewood or more environmentally friendly electric dryers), taking 1-5 days. It is the men who then scrub the dried fruits to make them smooth and separate the chaff by winnowing. 


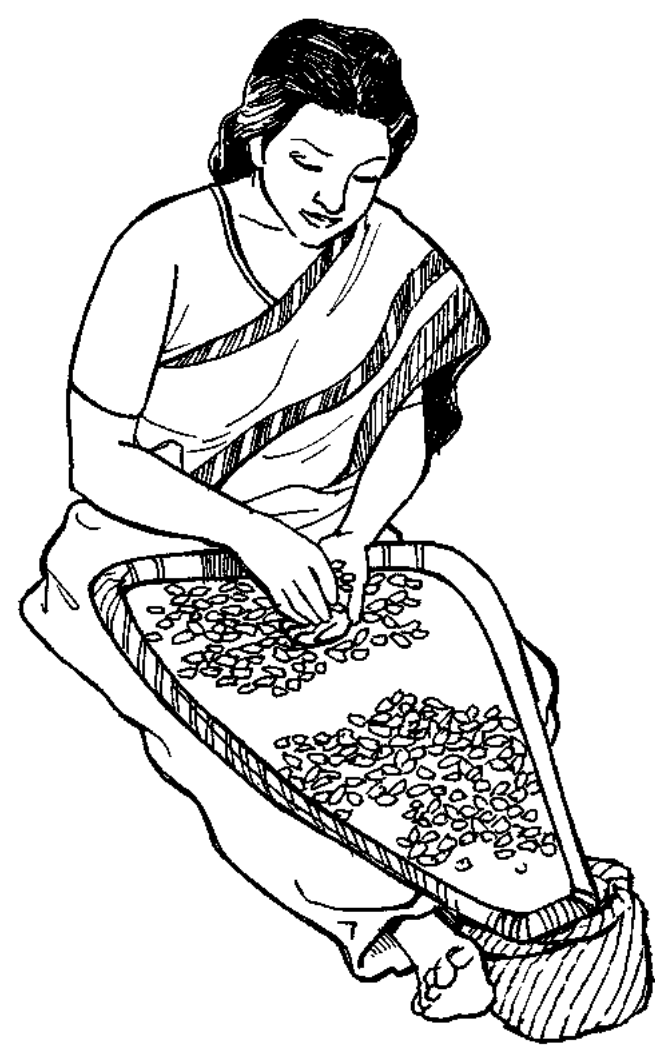

To maintain quality and in keeping with modern developments in the standardisation of agricultural products, the Government of India has prescribed 30 grades for cardamom fruit, three for seeds and one for powder. After grading, the fruits are packed into gunny sacks*, with a polythene lining, and are sent off to trade centres.
The berries are hand picked and then dried, graded, packed and transported to a trade centre. There, they are finally graded according to the 'Agmark Grade Specification Rules for Spices' and are sold at public auction. This is a highly transparent process, with the producers, auctioneers and traders all having strong representative organisations, some of which are more than a century old. For those involved in the various aspects of cardamom production and trade, assitance is also available in the form of technological and financial support from private research and government bodies, and financial institutions.

\section{The rise of the cardamom trade}

Prior to the twentieth century, cardamom was purely a natural forest product, which tribal forest communities collected, dried and traded. A high demand and value has led to commercial cultivation and crop improvements and today, wild cardamom can rarely be found within the marketplace. In recent decades, the demand for cardamom has increased significantly, a trend that is continuing. This is having positive flow-on benefits for farmers, traders and communities living near the cardamom tracts.

Compared to alternative land uses, cardamom cultivation is less environmentally destructive and more lucrative, providing incomes for producers and workers that are higher than for other crops or the national per capita average. Cardamom is a gift from the forests that offers good potential for financial success and is associated with a high social status. Profits from the harvest and trade of cardamom have supported the upbringing of many a statesman, educator and professional. In fact, the producers and traders of the 'Queen of Spices' have come to wield substantial social and political influence. 


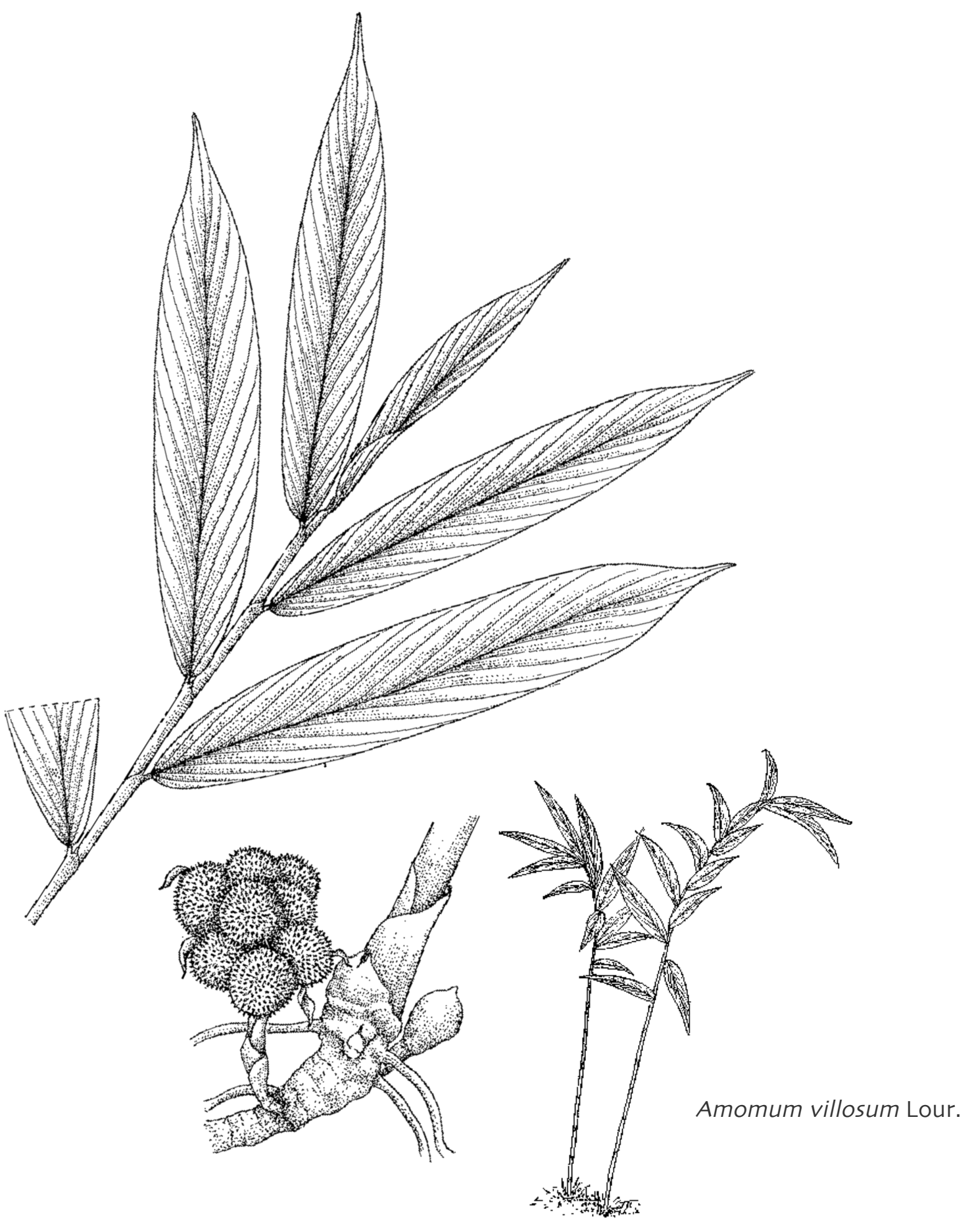

\section{Cardamom seeds}

Lao case by Catherine Aubertin 


\section{Drifting cardamom: From Lao fields to Chinese medicine markets}

Medicinal cardamom is highly sought after and widely used in the traditional Chinese pharmacopoeia. It is a different genus and species and quite different from common cardamom, the source of the well known Indian cooking spice of the same name (see previous chapter). The exportation of Lao cardamom into China for medicinal purposes dates back perhaps a millennium and the trade has grown to represent Laos' largest agricultural export, after coffee. In today's market, the key destination for medicinal cardamom remains China, where the seeds are processed into essential oils. Later imported back into Laos, this value added product is sometimes found on the shelves of Lao markets as vials or gelatine pills, believed to have curative properties for the treatment of stomach pains and digestive disorders. Most cardamom harvesters however, have little idea about how the cardamom they gather is either processed or used.

Around $80 \%$ of the Lao people are rural based and for upland populations the harvesting of forest resources is a traditional way of life. Forest products are used on a daily basis and are also traded to generate income. The harvesting of cardamom, locally known as 'mac

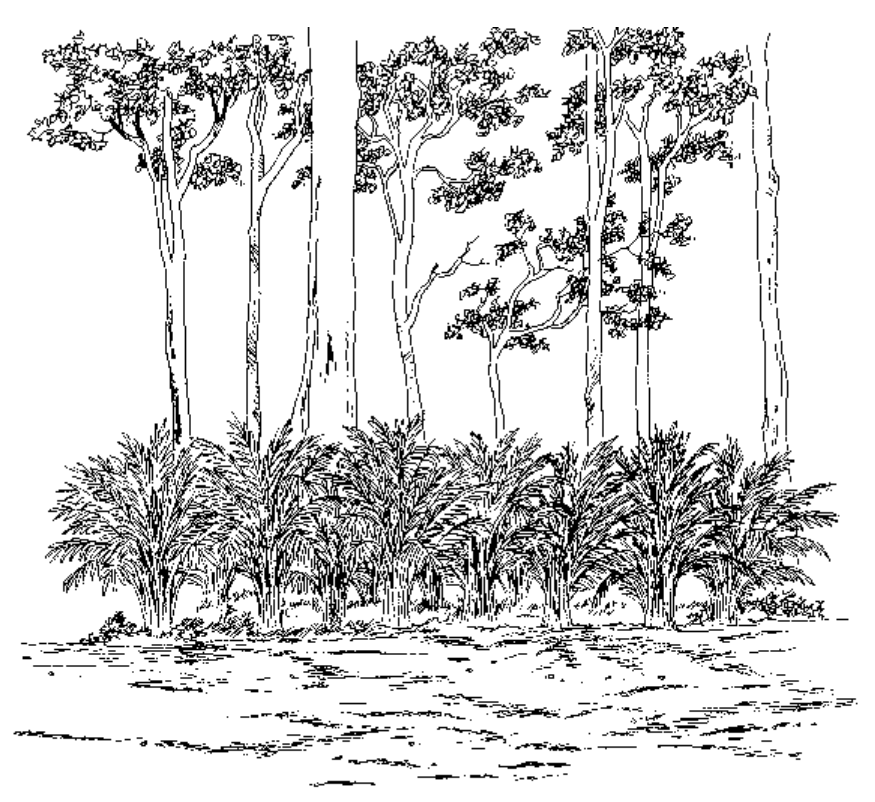
neng', is a key example. Thoroughly integrated into the cycle of upland rice production, it represents the main source of cash income for a majority of families from forested areas. Wild stocks are drawn upon but also, cultivated cardamom is planted at the same time as rice, producing satisfactory yields for many years during the long fallow: period required to restore soil fertility. These cardamom plantings facilitate preparation of the soil while also choking out invasive weeds.

\section{The domestication of cardamom}

Cardamom is a non-woody plant, which has large pointed leaves and reaches the height of a man (1.5$2 \mathrm{~m}$ ) when mature. It can be found throughout Laos (and other parts of South East Asia) and grows most 
readily in regenerating secondary forests*, particularly near water courses and at an altitude range of $700-1400 \mathrm{~m}$. The people of Laos manage cardamom in three different ways. They favour the growth of wild cardamom, which spontaneously sprouts* under the cover of the forest canopy. They also plant domesticated* cardamom in the forest themselves or alternatively, plant seedlings out in newly established rice fields.

Cardamom flowers from April to June, with the young plants producing their first fruits in the third year of growth. These fruits can then be collected annually,

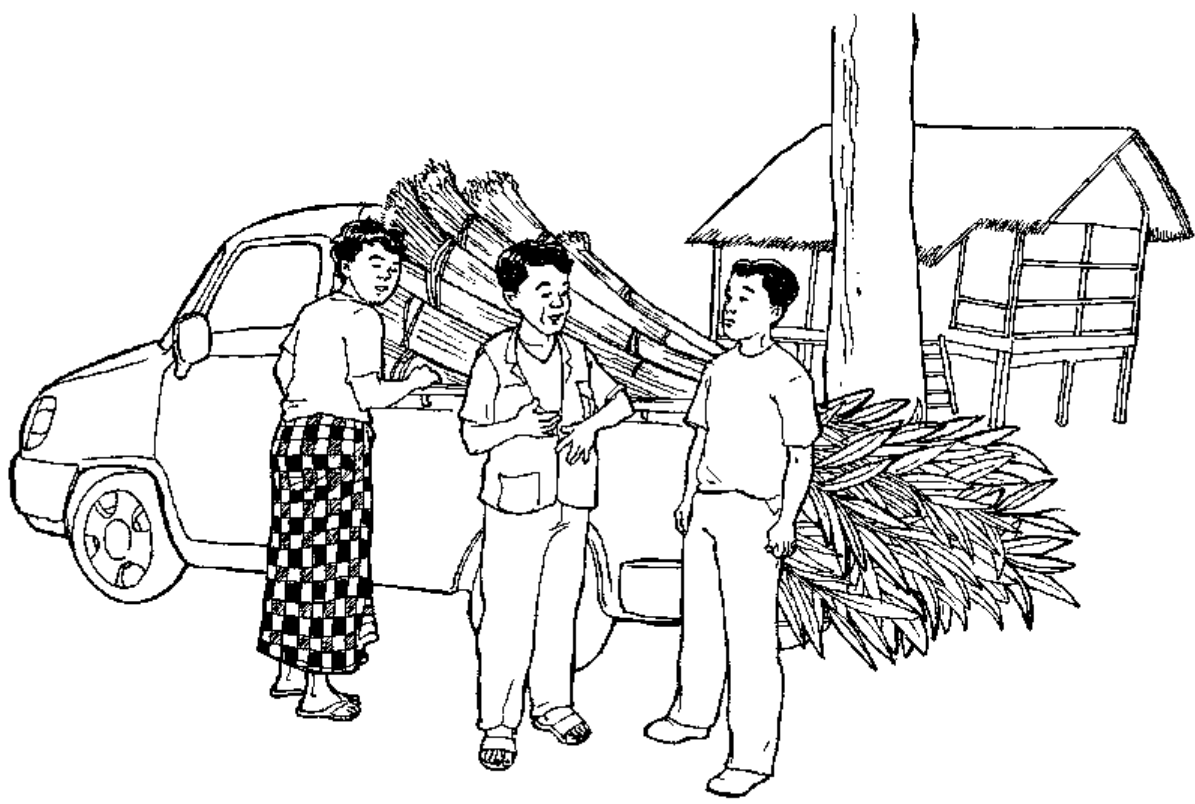

Nursery seedlings (grown from seed or cuttings) and even mature plants are transported for planting in rice paddies or newly cleared fields. sometimes for a period of more than 30 years. A simple knife is used to detach the fruits, which are around $2 \mathrm{~cm}$ in diameter and are borne on the roots as eg shaped capsules containing the little cardamom seeds. These capsules are carefully picked off the stolons (stems that run along the ground just below the soil surface).

Cardamom is one of those unusual plants for which harvesting tends to not only maintain the plant but to even increase its yield, particularly where the immature fruits are left to ripen and the plant is not uprooted during harvesting. Managing cardamom is not very labour intensive, involving planting and a little weeding. Chemicals are not needed and the local environment remains unharmed throughout the harvesting process.

A single plant yields approximately 50 capsules or $10-50 \mathrm{gm}$ per year. Plantation harvests account for around $100 \mathrm{~kg} /$ hectare/year. Nowadays, the medicinal cardamom grown in Laos, rather than coming from local varieties, is often from standardised, imported varieties (mainly Amomum villosum), brought into cultivation through various development projects. With these plantings becoming productive, it is likely that two thirds of the total harvest is currently being produced in plantations. 


\section{Trading the harvest}

At the end of the rainy season, an entire village may participate in the collection of wild and cultivated cardamom, just prior to the harvesting of rice. This fills an important seasonal gap in the availability of food and income and benefits even the poorest of families. After collection, the cardamom capsules are dried (a process which can take around 15 days), before being bagged for sale. The capsules are simply spread out on the ground in the sun, or when smoke dried, are placed onto a metal sheet or bamboo platform. It is the women who negotiate with middlemen regarding the sale of cardamom, with the buying price for whole, dried capsules ranging from US\$ 1 per $\mathrm{kg}$ (in the north, far from communications and transport routes), to about US\$ 3 per $\mathrm{kg}$ (for cultivated cardamom from less remote regions). The traders re-sell to wholesalers in town, who further dry the capsules and export them in $60 \mathrm{~kg}$ sacks, at around US\$ 5 per $\mathrm{kg}$. The Chinese market

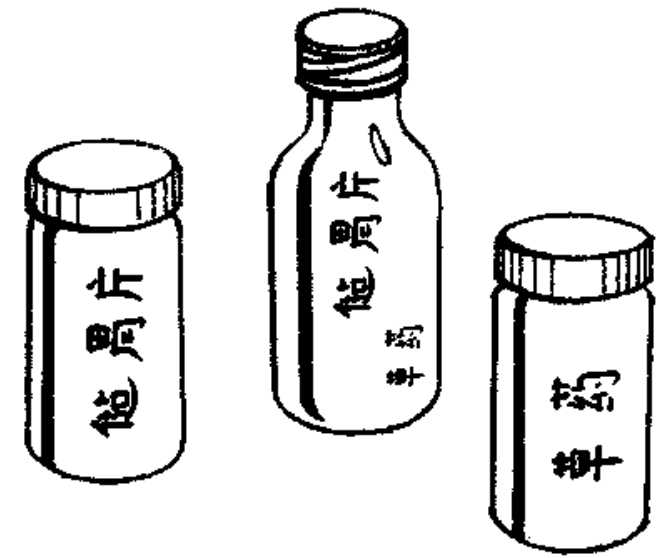

Cardamom that leaves Laos as a raw material sometimes reappears in the Lao markets, in the form of Chinese medicinal remedies. Although curiously, cardamom is not used in Laos' own herbal medicine. imports more than 1,500 tonnes of this produce each year.

One problem the cardamom harvesters face is the Government's land use and tenure policies threatening the agroforestry* and shifting cultivation* activities that support traditional cardamom production. Within the current system of forest zoning peasants no longer have rights to seek and collect wild cardamom in protected forests. Moreover, the prohibition of slash and burn* does not allow for the clearing that is required for establishing young cardamom plants in older, degraded forests. Also, the land allocation program, which makes long fallow periods impossible, is incompatible with the life cycle of cardamom. Studying cardamom in Laos brings into question some of the existing environmental policy goals and highlights the constraints these are having on the country's production of cardamom. Yet, despite such unfavourable factors, the commercialisation of this forest product is continuing to grow. 


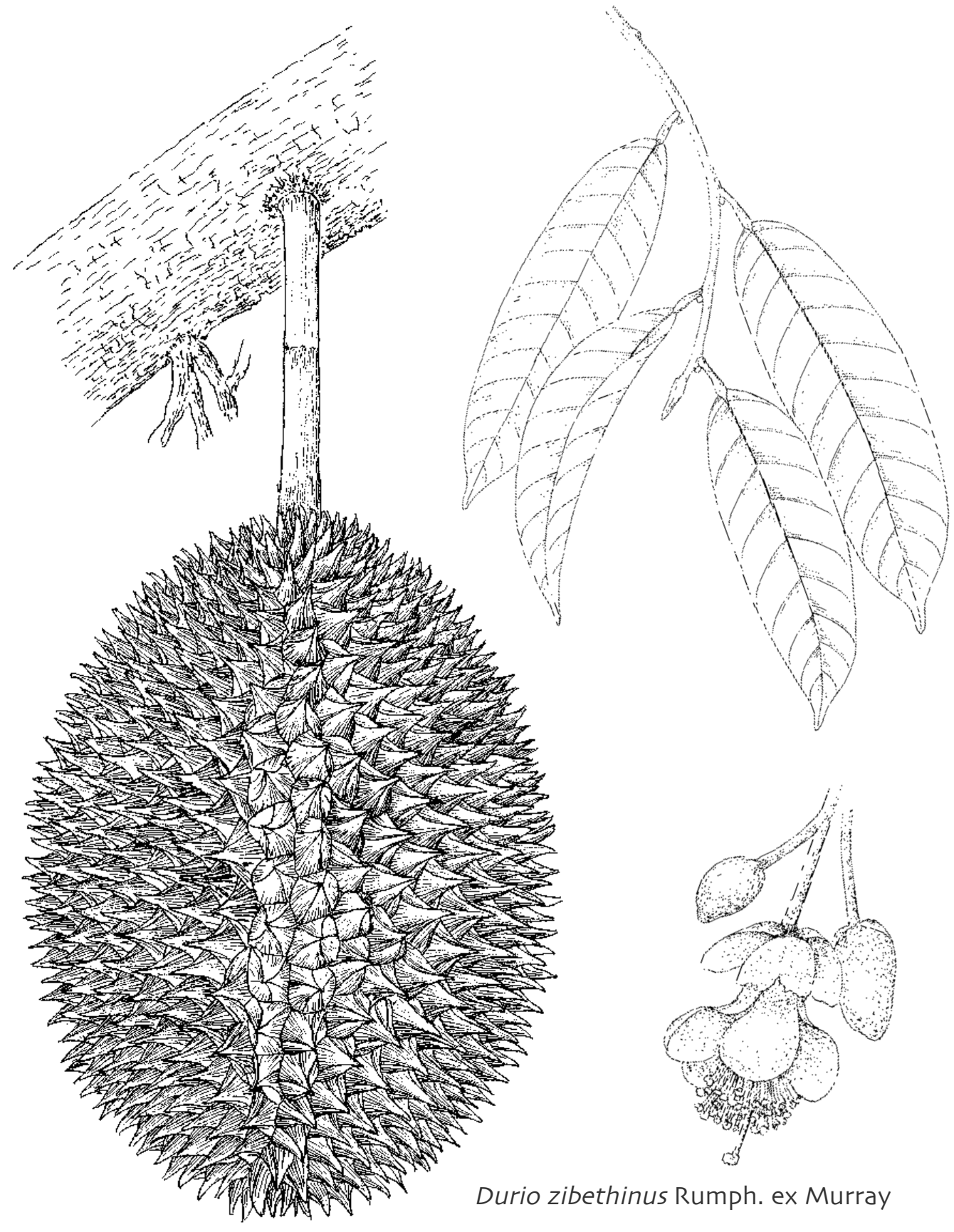

\section{Durian}

Indonesian case by Marina Goloubinoff and Renni S. Hoshi 


\section{Durian: Smells like hell but tastes like paradise}

Sleeping in Tarutung, in Indonesia's North Sumatra, a loud noise startles us in the middle of the night. Looking outside, we see our neighbour's daughters searching for something in their garden. "Here it is!" calls the youngest one, pointing at the spiny monster with her torch - a lovely $3 \mathrm{~kg}$ durian. The fruit had just fallen from the tree overhanging the girls' hut, noisily bumping and rolling off its metal roof and alerting them that their precious fruit was now ready for the taking. Luckily it was not a durian tree that Sir Isaac Newton was standing under when he discovered the Law of Gravity - he might have been knocked unconscious!

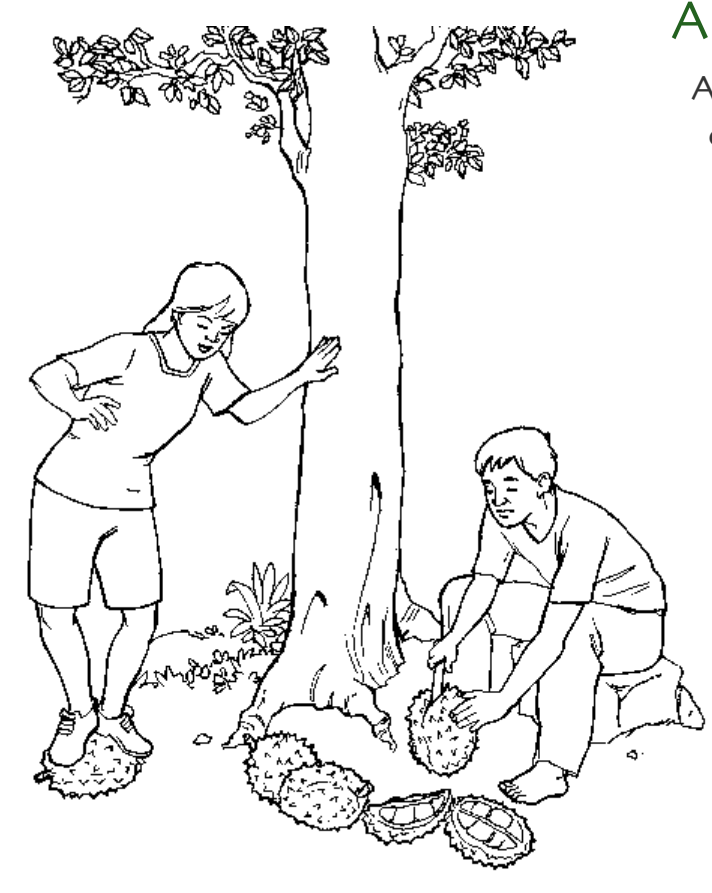

Durians are usually opened with a machete but people in East Java use a more acrobatic method - standing on the spiny fruit with all their weight!

\section{A matter of taste}

According to British naturalist, Richard Wallace, "To eat a durian is a new sensation, worth a voyage to the east to experience". If you are in South East Asia during the durian season, don't let the fruit's offensive odour discourage you. Find a skilled person to open the fruit and after tasting its creamy flesh, see if you agree with the following description from Wallace: "Consistence and flavour are indescribable. A rich butter-like custard highly flavoured with almonds gives the best idea of it but intermingled ... comes wafts of flavours that call to mind cream-cheese, onion sauce, brown sherry, and other incongruities."

The best way to eat durian is by the roadside, purchased fresh from farmers. Don't take it into your car though because its infamous smell is truly terrible! This is why durian is forbidden in cabin luggage and hotels. The fruit itself is highly nutritious, containing proteins, carbohydrates and vitamins like $B, C$ and beta-carotene. It is sometimes used to flavour foods, from chili sauces, to cakes and ice cream - and in recent times, even condoms! The Malays, believing durian is an aphrodisiac, have a special saying: "When durian falls down, sarong goes up!" 


\section{A valuable tree}

Durian trees are easily recognised by their conic shape and bronze coloured leaves. In the forest, they often grow taller than other fruit trees, up to $40 \mathrm{~m}$, although the cultivated varieties are much shorter. The genus* Durio includes about 30 species in Asia, six of which are edible. The most popular is Durio zibethinus, (meaning 'civet cat durian' in Latin). This particular species has long been domesticated" and includes hundreds of varieties. Durian is believed to be native* to Sumatra and Borneo but its distribution now extends from India to New Guinea. This fruit tree is particularly important in Thailand, Malaysia and Indonesia and certain regions of Vietnam, Myanmar and Cambodia. Durian's popular and unique taste has also led to its cultivation in Australia and its experimental introduction into places like Zanzibar and North America.

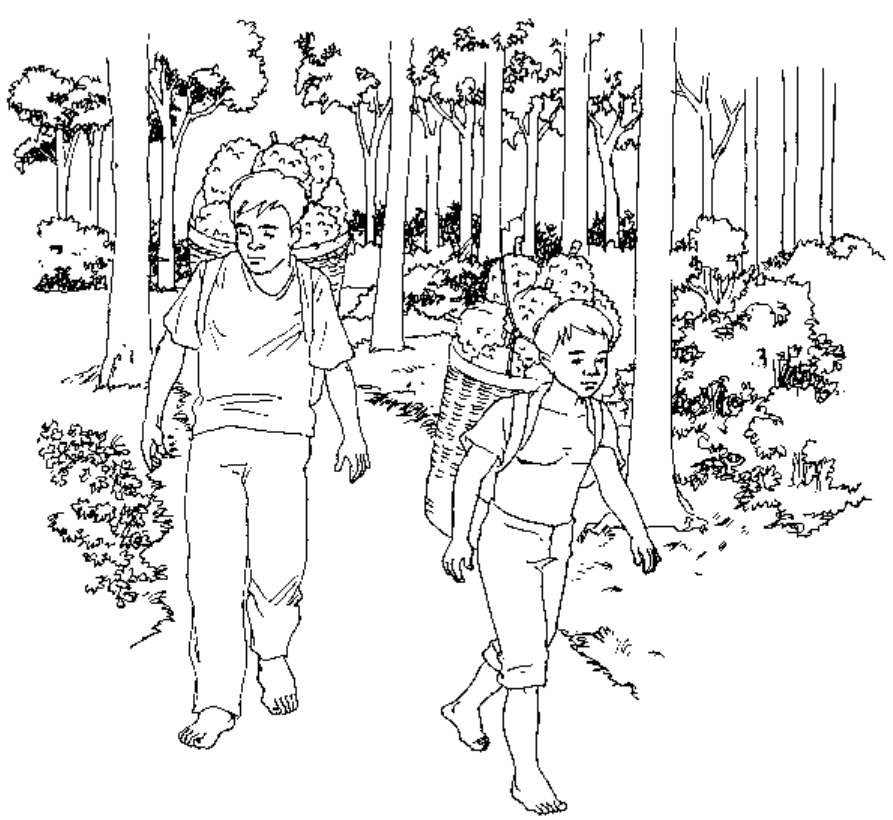

Durian is often harvested from agroforests, where Durio trees are cultivated along with other useful species which yield products like damar and benzoin resin, rubber and cinnamon.

In Indonesia, durian is often cultivated in home

gardens or agroforests*. Today's groves of durian are a legacy of the management practices of Sumatran and Javanese farmers who, over centuries, selected the tastiest varieties. The farmers' knowledge has paid off, as durian has become one of the region's most profitable fruit trees. A mature tree can produce $200-800$ fruits a year. Even when they are sold for only US\$ 0.25 per unit, this still provides a good income for a rural family - and an income source that can be passed on for up to four generations. Because of its high value and long productive life, several families sometime manage durian on a rotation basis. During the harvesting season, each family stays in the garden on certain days to guard and collect the ripened fruits that fall from the trees.

Throughout the harvesting season in North Sumatra, durian tree owners find themselves surrounded by friends and relatives. They are obliged to give away some of their fruit, believing that otherwise a spell will befall them, making them sick or killing their durian tree. In West Java, when a farmer needs to borrow money, these valuable trees can serve as security. Instead of charging interest, which Islamic Law doesn't allow, the lender receives profits from the durian harvest until the loan is paid back. 


\section{Petruk versus golden pillow}

In Javanese shadow theatre, Petruk is not a good looking man but he is simple and has a good heart. The same could be said of the Indonesian durian that bears his name, along with some of the country's other varieties. Their quality may be irregular but connoisseurs love them. 'Mon thong' or 'golden pillow', the popular Thai durian is different. It is large and nicely shaped, with a lot of flesh and a mild taste. Improved Thai varieties such as this can now be harvested before maturity and exported throughout the region and beyond. Indonesian varieties on the other hand, are poorly known, except in Singapore, Malaysia and Holland (Indonesia's former coloniser, where people still remember the taste). Thailand leads international production with 950,000 tonnes per year, followed by Malaysia. Indonesia comes third, producing 200,000 tonnes. National production is insufficient to meet the desire of Indonesians for durian, so additional supplies are imported from Thailand.

Indonesian businessmen blame the lack of greater production on insufficient interest from investors and government and some dream of orchards full of cloned* durians. Greater production might also be stimulated through the expansion and intensification of sophisticated local systems of management. To optimise local durian and access new venues for sale, such as supermarkets, better packaging and transportation conditions

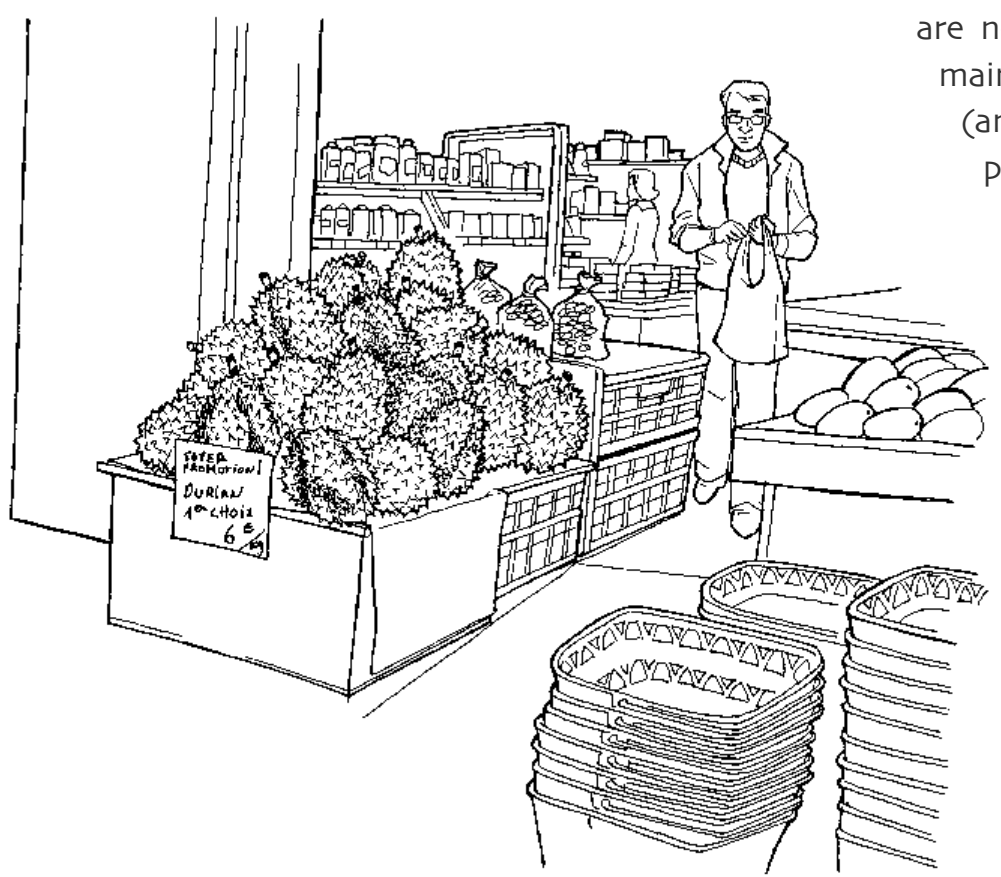

Certain Thai varieties can be harvested before they ripen, facilitating export. This means durians found in places like Paris' Chinese quarter can still be bought fresh. 


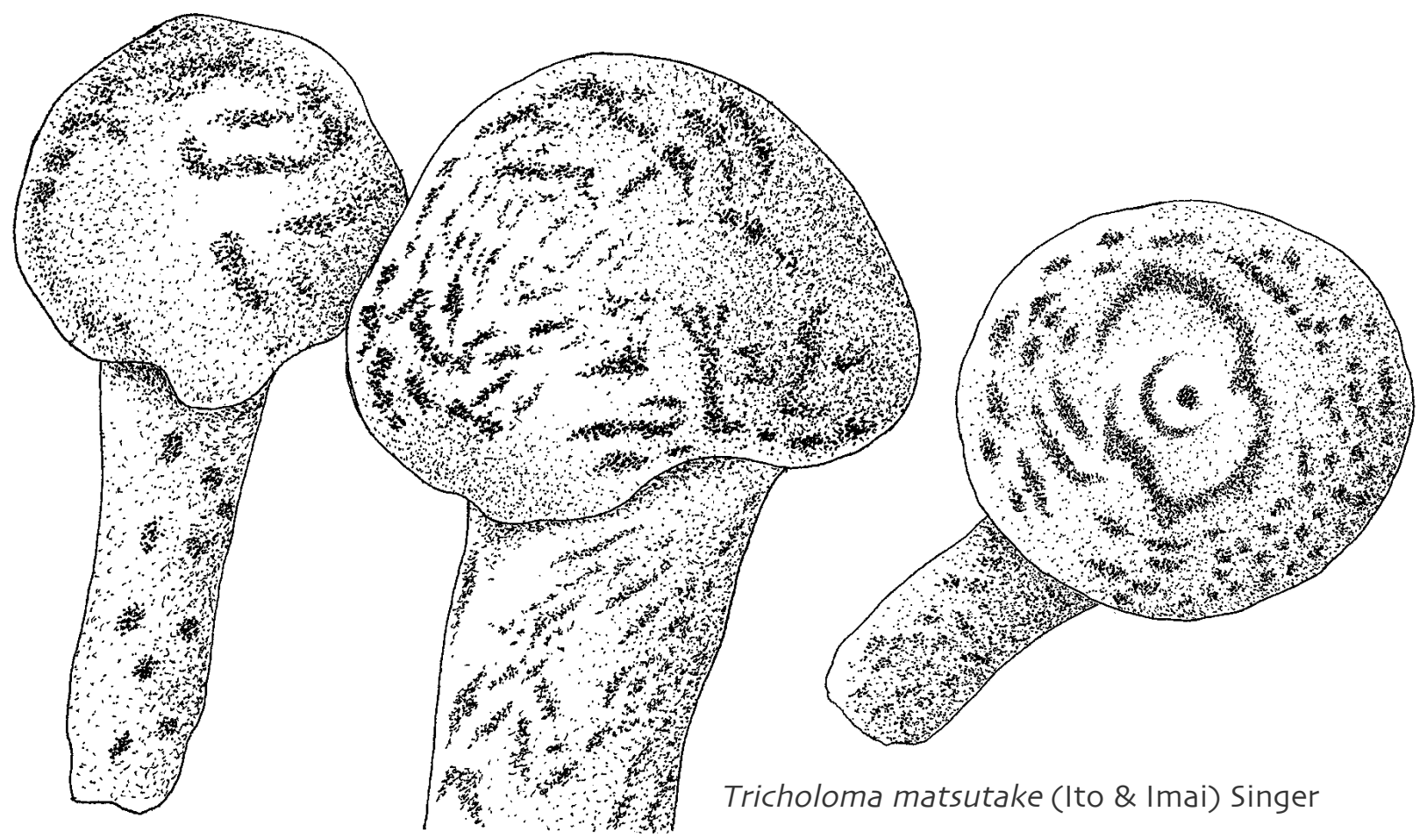

\title{
Song rong mushroom
}

\author{
Chinese case by Ying Long Chen
}




\section{Song rong: Good fortune and fertility from a fungus}

Considered an autumn delicacy, 'song rong' mushrooms (Tricholoma matsutake) have been used and revered by Chinese and Japanese people for more than a millennium. Of all the edible fungi in China, they are the most valuable, with a farm gate price of up to US\$ 370 per $\mathrm{kg}$ for the highest quality produce and a total national value of around US\$ 8 million. Often, the same day that mushrooms are collected from the forest floors of China, they are cooked and served in restaurants in Japan. About $95 \%$ of the collected song rong is sold fresh and exported to Japan, with Chinese mushroom industries buying the remainder and processing some of this into dried, salted and canned products.

Nutritious and believed to have medicinal properties, song rong has a delicious taste and lends a special flavour to a range of dishes. It is often served in a soup, along with green vegetables, cooked with rice or stewed with fish, vegetables, sauce and vinegar, imparting a strong odour and a characteristically rich taste.

Song rong symbolises fertility and by extension, represents

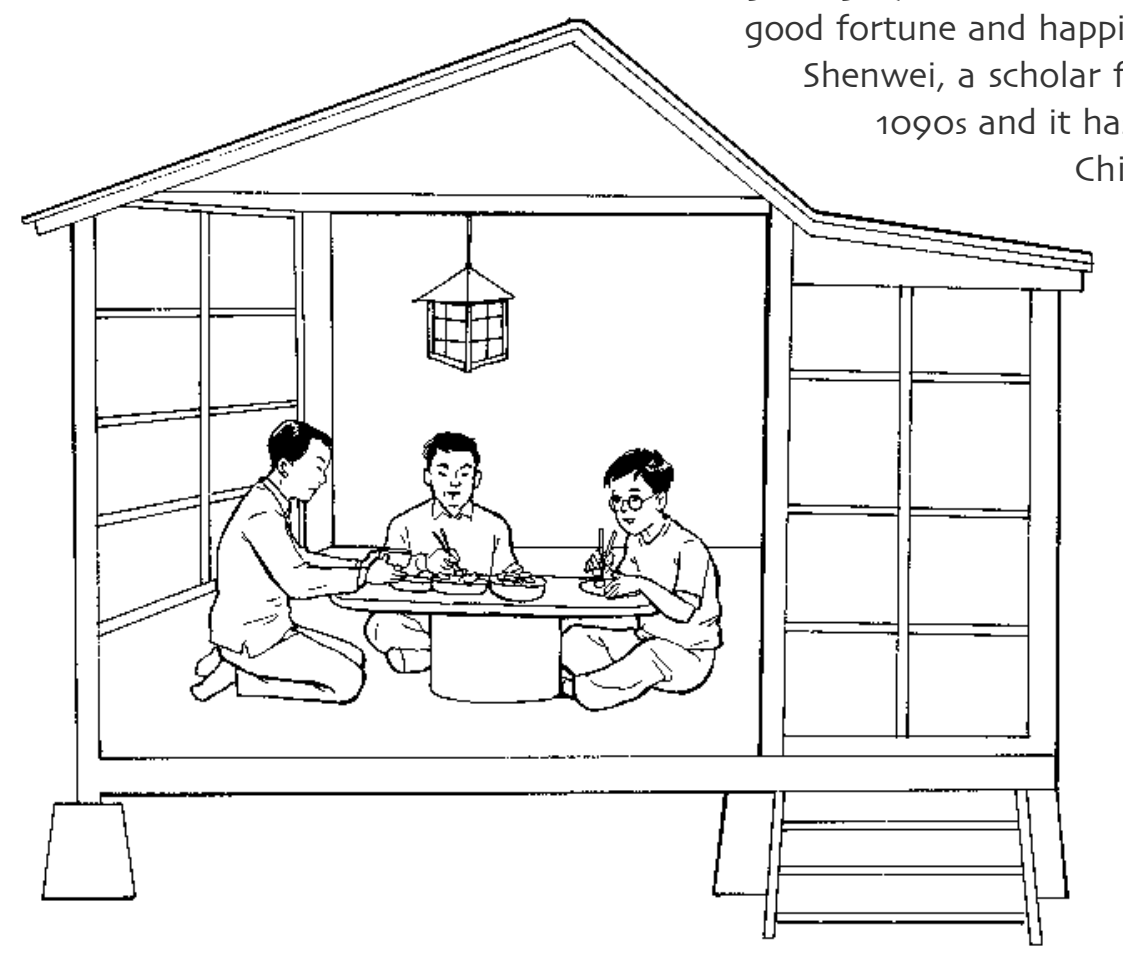

Fresh mushrooms are often delivered on the same day, from China's forest floors to Japan's restaurant tables. 


\section{From the forest floor to foreign markets}

Song rong is found in coniferous forests* in Japan, China and Korea, in areas of extremely restricted ecological habitat*, with the two main regions of commercial production being in the northeast and southwest of China. In Japan, this forest fungi and similar mushrooms growing in coniferous forests are called 'matsutake' (matsu = pine; take $=$ mushroom). This term relates to their association with the fine roots of certain trees, like pines. Such a 'symbiotic' relationship is of mutual benefit, with the mushroom obtaining sustenance from the plant roots and in exchange, facilitating the uptake of mineral nutrients from the soil into the host tree*.

The Zixi Mountain Area, a Chinese National Park containing four village settlements, is one of the typical sites producing song rong mushrooms. Here, the collection of this forest resource provides essential income for more than $90 \%$ of local families. Local farmers are allowed to collect mushrooms for free, while visiting mushroom collectors from other areas need to pay an entry fee to access the Park.

Due to the high demand and competition for supplies, even juvenile buttons are collected. After gathering the mushrooms, selection, clearing and sorting takes place and the harvesters are then paid according to the weight of the fresh produce. In the station market of the Zixi Forest Park, only around $50 \%$ of the song rong are sold in the best quality categories (Grades 1-3). About $35 \%$ of the harvest is made up of young buttons, sold out of grade and with a much lower market value.

Following harvest, the rapid transit of song rong is critical, as it can only be maintained fresh for a couple of days. Soon after collection, most of the mushrooms are bought by local traders, who transport them to Kunming, the capital city of the Yunnan Province. From here, the bulk of the produce is flown to Japan,

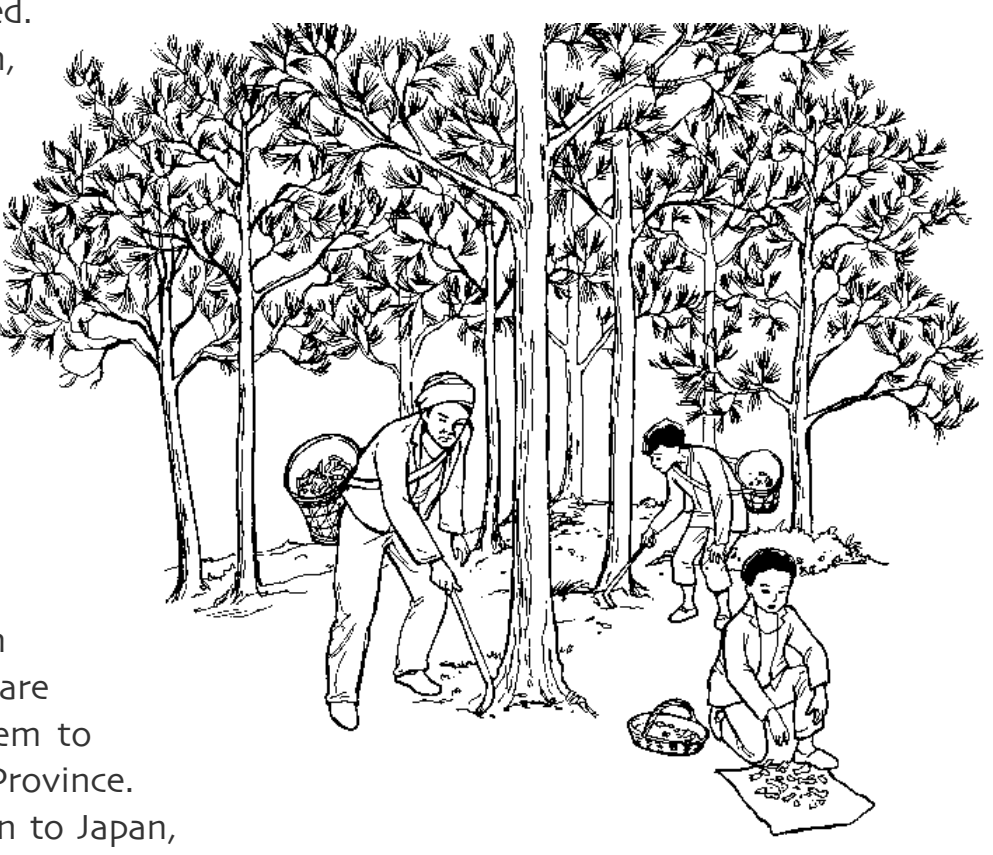
with a small portion remaining for local processing.

The mushrooms are collected with a curved blade on a short stick. Men, women and children walk around the forest, periodically disturbing the layer of leaf litter* on the forest floor, in search of song rong. 
The song rong that is dried, salted or canned in China needs to be treated while still fresh, for the sake of retaining flavour and a good price. Drying takes place immediately after harvesting, using solar energy or a heating system like a baking cabinet. Some mushrooms are canned while others are used to commercially produce song rong wine or cookies, although production is limited due to the shortage of fresh supplies.

\section{The challenges ahead}

Song rong is a best-selling, expensive mushroom in the Asian region and especially in Japan, where natural supplies have dramatically declined over the past 60 years, due to a combination of high demand and the over-exploitation of wild stocks. The regional demand has continued to increase though and as a result, so has the price. In turn, this has placed additional pressure on the remaining natural stocks, which have been unable to cope. Hence, the level of world production has now gone into
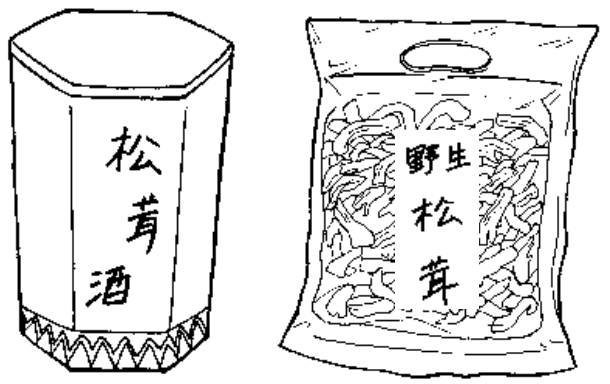
decline.

Over-harvesting and the collection of mushrooms in the early button stage have had adverse impacts upon prime song rong sites and on the capacity of this mushroom to regenerate. Site disturbance has also led to increased soil erosion and other changes in the ecological conditions that this fungus requires. Song rong is a valuable forest product with a proven commercial market but harvesters need to be aware of the detrimental impacts that the current collection practices are having.

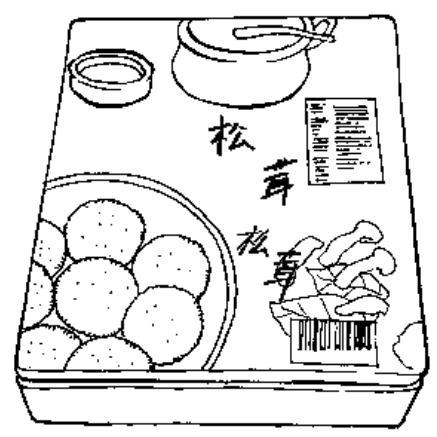

To foster more sustainable management*, research is required to develop industry standards and guidelines regarding the intensity and frequency of collection. Studies are also needed on the biology and ecology of this mushroom and its potential for domestication*. Song rong can be planted but little is known about the cultivation techniques for this particular mushroom. Knowledge about the farming of other expensive edible fungi, especially symbiotic species, like truffles, could assist in developing a cultivated song rong industry and a more secure future for this valuable forest fungi and the families who gather it. 


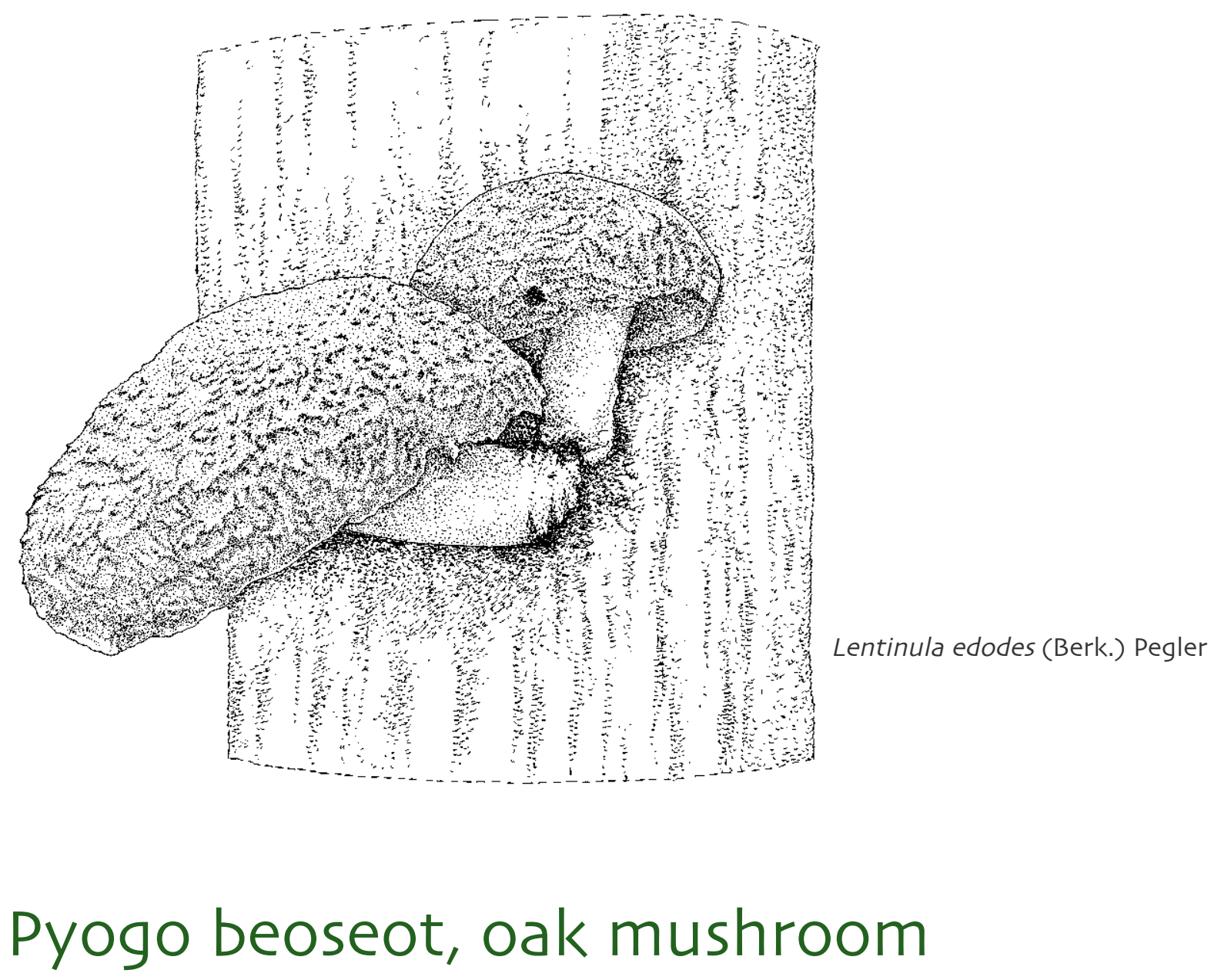

Korean case by Yeo-Chang Youn 


\section{Oak mushroom: From wild food to mass market}

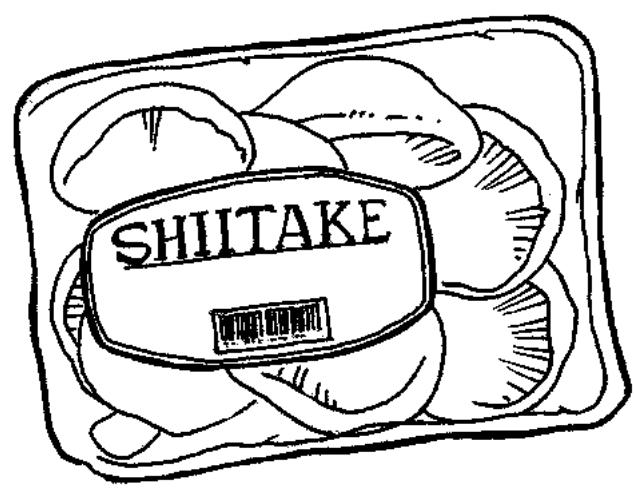

For centuries people living near forests have enjoyed natural delicacies unknown to city folk. The oak mushroom is one example, although in recent times this forest product has become popular in the cities too, where a growing market for it has developed. As the fruiting body of a fungus (Lentinula edodes), the oak mushroom grows on dead trees, particularly in oak forests - hence its name. But it can also be found on logs from other trees like beeches, maples and chestnuts. This mushroom is a non-timber product from the forests although it does rely on wood for its survival and growth.

Oak mushrooms grow naturally in many countries, ranging from Australia to Siberia and from Kazakhstan to Japan. They are known as 'pyogo beoseot' in Korea, 'shiitake' in Japan and 'xianggu' in China. Originally, this mushroom was only collected from the wild but China, which has used it for centuries as a food and in medicine, started to cultivate it on specially prepared logs. This practice soon extended to Korea and Japan, where the mushroom also has a long track record of use. Today, oak mushrooms have even been introduced into forest valleys in the United States of America and Europe - contributing to the "changing landscapes of foreign countries", as American agricultural professionals have described it.

The diet of forest people has long relied on nature's bounty, with mushrooms being collected for food as far back as people can remember. Today, as urban populations become more concerned about health and food safety, mushrooms are gaining in popularity, regarded as a natural and nutritious product, largely free from chemicals.

\section{Mushroom production}

In South Korea, pyogo beoseot has a history of cultivation stretching back more than 400 years. Recently, the government has been promoting further development of the industry, recognising it as an important source of income for rural communities, particularly as mushroom growing offers families $20 \%$ higher revenue, on average, than other crops. In 2000, there were 6,888 oak mushroom producers in South Korea, who collectively produced 17,531 tonnes of fresh produce. 
Korean mushroom growers first select suitable oak logs, measuring 6-14 cm in diameter, harvesting from trees in the winter after leaf fall (November-February). Traditionally, the cut logs are left in the forest to dry naturally for 1-2 months before being relocated to a shady site closer to the village. There, they are cut into smaller $1 \mathrm{~m}$ lengths to become 'bed logs' for seeding in early spring. Nowadays, electric drills are used to make the small holes into which mushroom spores are placed (inoculation). In the first year, the logs are seeded and treated with pesticides (unless the mushrooms are organically* grown), and regularly sprayed with water, to facilitate growth. In the second year, the mushrooms appear and these can then be collected over the course of the next five years. When cultivated in greenhouses the period of fruiting is shorter but production is more intensive.

The rising popularity of the humble oak mushroom has been a catalyst for the development of new varieties and improvements in production and processing technologies. The market has developed to the point where approximately $78 \%$ of the mushrooms are harvested from greenhouse cultivations. Many growers have built greenhouses, sometimes using sawdust bags rather than logs. Around $22 \%$ of the mushrooms are still grown under natural shade outdoors, with many smaller scale farmers continuing to grow them the traditional way, in addition to rice and other crops. As demand further increases, farmers are responding by growing more mushrooms. However, the price has decreased with the rapid expansion of supply from both domestic and overseas producers.

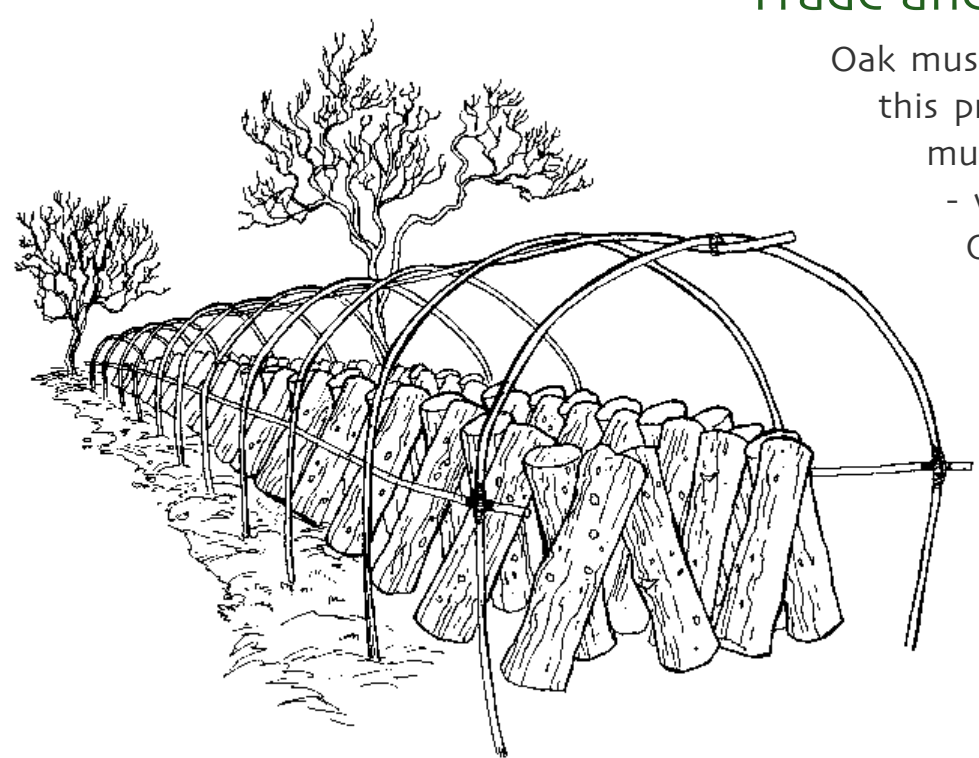

Oak mushrooms are being cultivated in greenhouses to meet the growing demand for this popular natural food.

\section{Trade and marketing} mushroom production in Korea is dried prior to sale - with the dried produce fetching a lower price. Oak mushroom farmers usually have their own driers, using petroleum as a source of energy but for small quantities, the mushrooms are sometimes simply dried in the sun. Some growers sell their mushrooms directly to merchants, who then market them to wholesalers or distribution centers. Other farmers have organised a co-operative for the collective sale and marketing of their products, dealing directly with distribution centres in large cities like Seoul. 
The production of oak mushrooms in South Korea has increased, attaining a value of around US\$ 137 million in 2001. However, the growing domestic supplies have still been unable to meet the average consumption per household (which in 2001, reached 117 $\mathrm{kg} /$ year). To make up for this shortfall, imported supplies (mainly dried, from China) have been on the rise, increasing from 329 tonnes in 1990 to 1,139 tonnes in 2000.

South Korea's love of oak mushrooms is leading to an increasing number of oak trees being harvested to obtain bed logs (with about $200,000 \mathrm{~m}^{3}$ of oak logs being used for mushroom production in 2000). In recent years, both forest owners and local and national government agencies have come to recognise the importance of growing oaks and making stand improvements, particularly as this timber is more profitable than that of conifers*. The boom in mushroom sales and cultivation could help to inspire the preservation of these valuable native trees. Conserving the oak trees that harbour these mushrooms can ensure that this delicious wild fungus continues to grace the dinner tables of homes and restaurants in Asia and beyond.

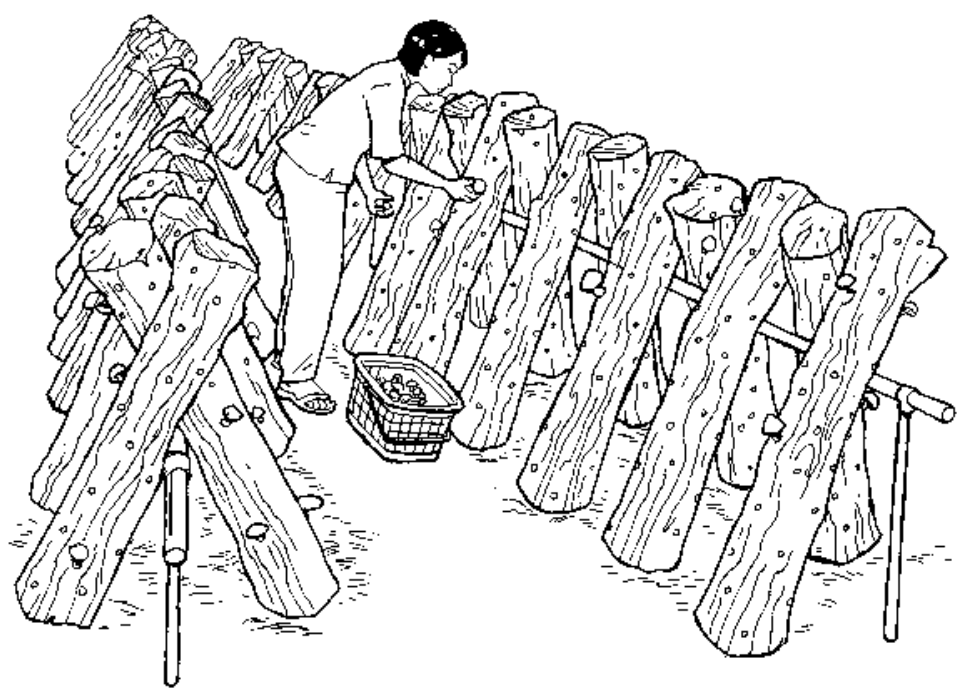

Mushroom growing relies on an individual family's own labour force, with the women playing an important role in inoculating, harvesting and drying the mushrooms. 


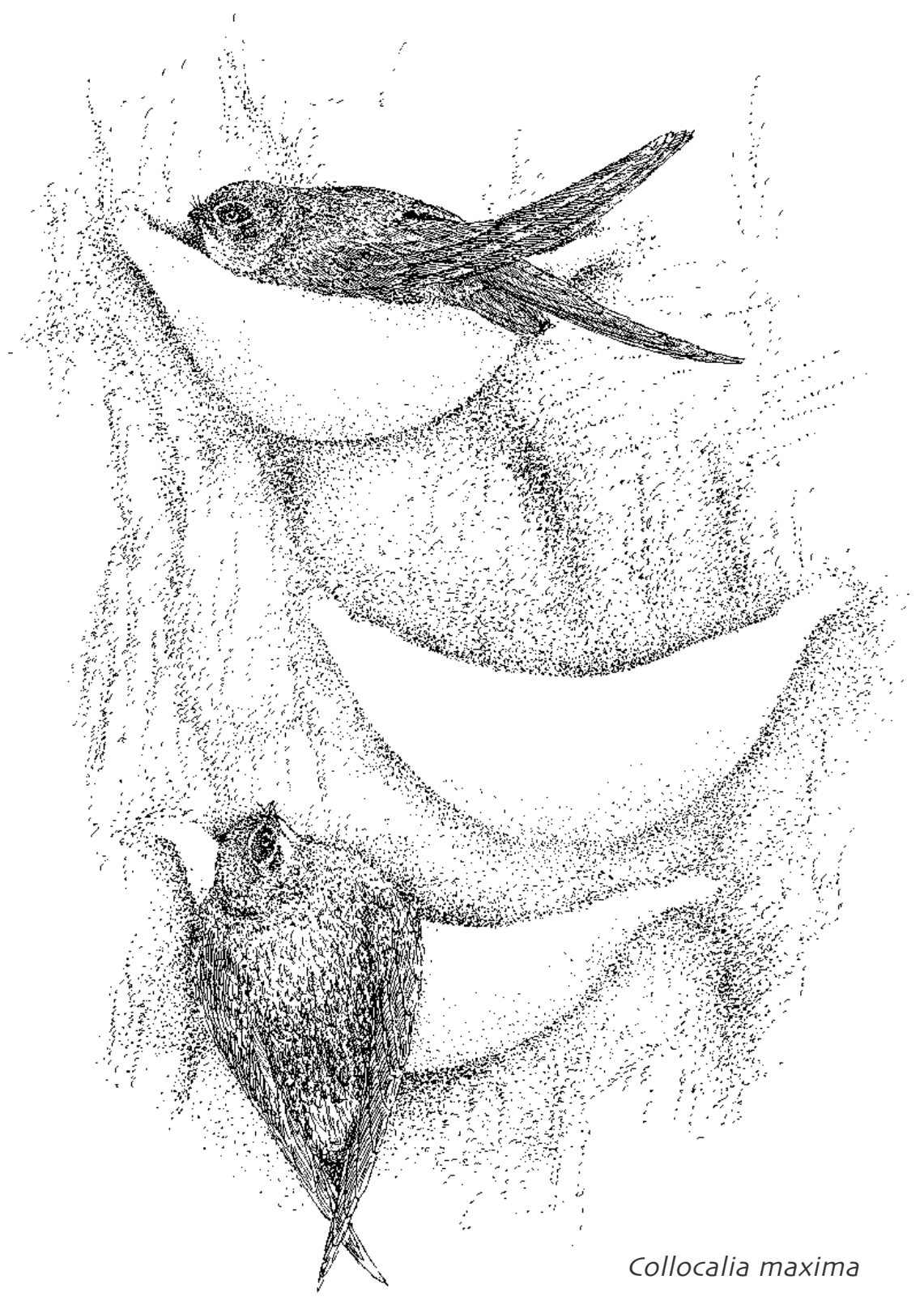

\section{Swiftlets, edible birds' nests}

Indonesian case by Marina Goloubinoff 


\title{
Edible birds' nests: Transforming saliva into gold
}

\author{
Have you ever had the chance to eat birds' nest soup - \\ one of the most famous dishes in Chinese gastronomy?
}

Imagine you are in Hong Kong and your Chinese friend invites you to a restaurant. On his advice, you agree to eat birds' nest soup but are a bit worried about what will end up swimming in your bowl. Your friend explains this soup is said to be very healthy and capable of increasing longevity, cleaning your lungs, curing your asthma and preventing osteoporosis! Pregnant women also eat it in the belief their babies will have smoother skin.

\section{What does it look like and how do you eat a bird's nest?}

It looks like rice vermicelli but with a different taste and texture. The creators of these edible nests are Asian swiftlets or walet birds (Collocalia spp.), which are found mostly in Indonesia (especially in Java, Kalimantan and Sumatra) as well as Malaysia, Thailand and the Philippines. A common misconception is that these birds are actually swallows and while the two may look similar, a fake Chinese proverb warns: "Don't swallow swallows' nests otherwise you may miss spring."

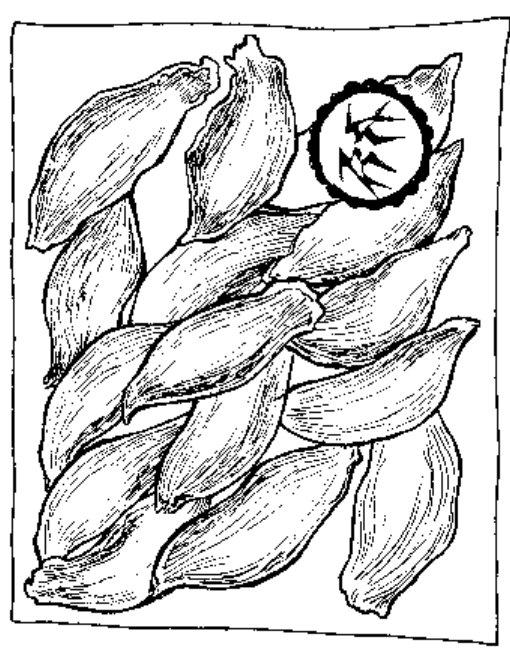

\section{What is so special about these nests?}

The birds make their nests with saliva! They fly about all day catching insects and on returning home at sunset, chat awhile with the neighbours before turning to the important task of nest building with their spouses. Some species gather twigs to create the underlying structure, sticking it all together with saliva. Others use saliva alone as the raw material, like C. fuciphaga, which produces the most expensive 'white nests'. In 1998, good quality ones were fetching US\$2,000 per $\mathrm{kg}$ in Indonesia and US\$ 3,000 in Hong Kong. 


\section{Why so expensive?}

These nests are a relatively rare commodity and quite difficult to obtain. In the past, only imperial families and the very rich could afford them. The swiftlets like living in forest caves, particularly limestone ones near the seashore but their tendency to nest deep within makes nest collection both difficult and dangerous. Harvesters enter the often steep and slippery caves, using ropes and bamboo ladders. This activity can be so hazardous that even skilled collectors have been known to fall over $30 \mathrm{~m}$ to their deaths.

In some places, local government (e.g. in Kebumen, Central Java) or concession companies (e.g. in Kalimantan) have erected permanent ladders and installed generators to facilitate cave harvesting. But a new danger has arisen - robbery! Many harvesters are even resorting to carrying guns or hiring soldiers to protect their bounty. In Indonesia, conflicts have occurred between communities, local government and concession companies over access to the caves and their edible treasures. Ownership laws and exploitation rights need to be clarified to help foster property security, reduce violence and provide incentives for sustainable management*.

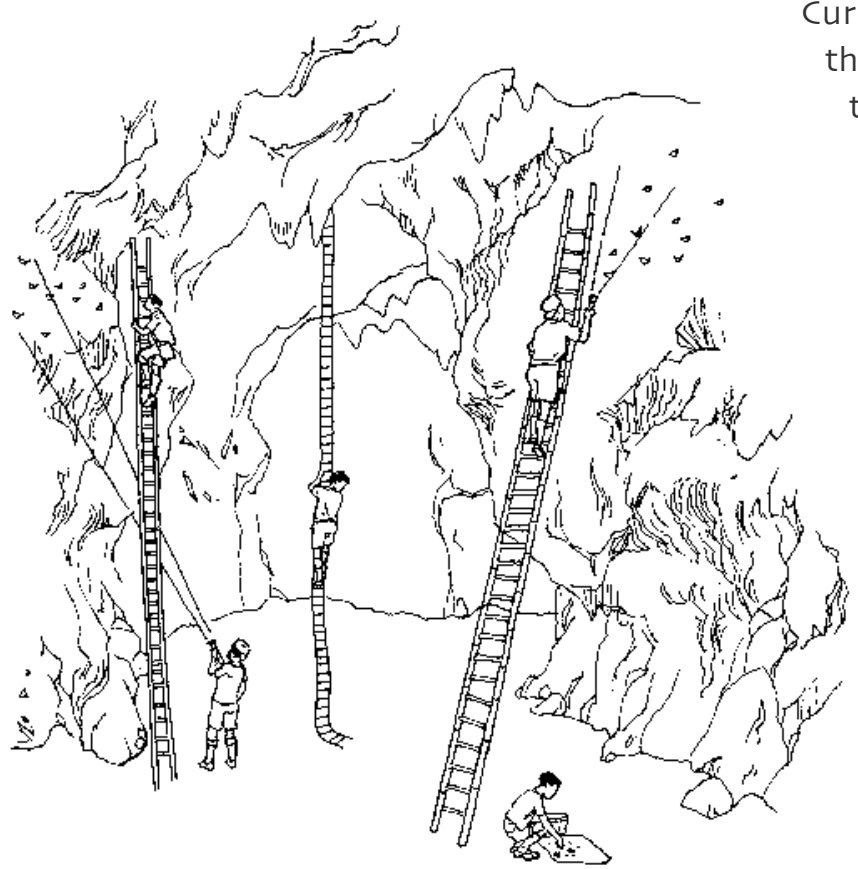

The biggest caves are located in Kalimantan, while the oldest record of cave exploitation is found in Karangbolong, Central Java, dating back to the seventeenth century.
Currently, over-exploitation and forest destruction threaten the cave dwelling swiftlets. In a bid to address this, people have developed specialist knowledge and artificial breeding programs, recreating cave-like conditions in houses - with darkness, and the right temperature and humidity. To attract birds, families use cassettes playing swiftlet nesting songs, fishy perfume and rotting fruits, encouraging them not just to enter but to stay and nest. Although, once inside it is not simply a matter of closing the doors and windows because the birds need to fly out every day.

These giant bird houses are a bit like five star hotels - offering the best service to ensure guests return and recommend the place to their friends. Today, there are literally thousands of these 'substitute caves', having first appeared on the northern coast of Java about 200 years ago. Traditionally, swiftlet keeping would happen 'by accident', with a few birds starting to nest in an abandoned building. The owner, with a little bird keeping advice, would then adapt the place accordingly.

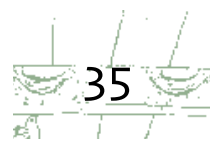


Economic changes in China in the early 1990s, with a growing number of wealthy businessmen wanting to enjoy luxury products, led to a significant increase in new bird houses. In Indonesia, swiftlet keeping is seen as a promising business opportunity, particularly amongst the urban middle class and bird houses can now be found in many parts of the archipelago (and in certain places in Malaysia and Thailand). Some businessmen, mostly ethnic Chinese, spend more than US\$ 10,000 on special buildings - even though there is no guarantee the birds will take up residence.

\section{Can you eat your soup without feeling guilty?}

You will probably get a C. fuciphaga nest from an artificial habitat* because that is the preference in Hong Kong, the main importer. China also buys the nests, with Indonesia being the biggest producer. Its official export estimate is several hundred tonnes but the real figure is likely to be far higher.

Breeding programmes are on the rise but it can't be said that all swiftlets can be saved in this way. For example, C. maxima, which makes 'black nests' (because of feathers that are later removed), has not yet been domesticated* and it is not sufficiently protected within the caves. Today, around half the nests on the market come from breeding programs. The one in your soup is probably OK. So, now that you know some of the natural history behind your dinner - Bon Appétit!

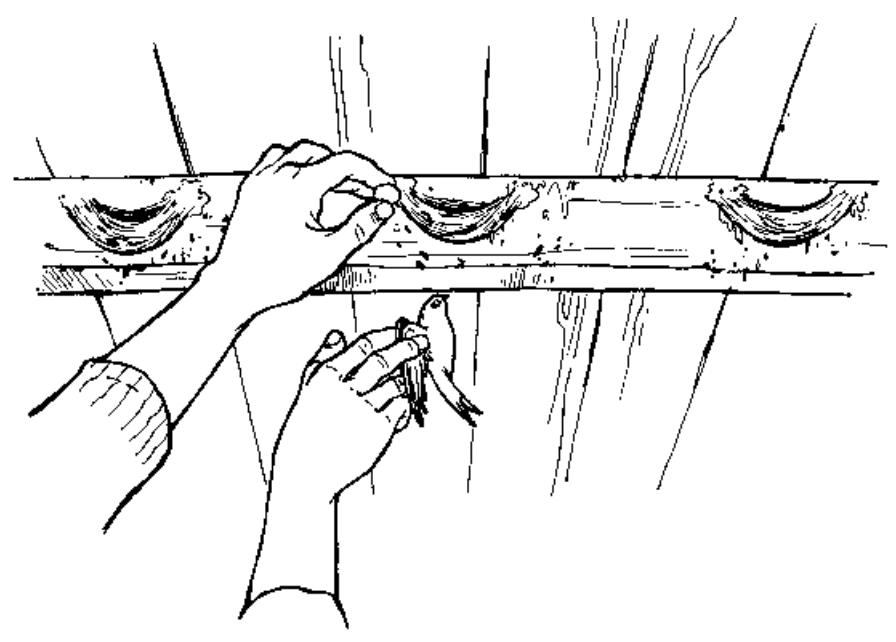

In Java, C. linchi (known locally as 'seriti') is often the first to colonise a house, adapting easily to new habitats. As its nests contain twigs, keepers substitute its eggs for those of the fussier 'walet' or C. fuciphaga-producer of quality, pure saliva nests. With seriti foster parents, the walet offspring and their descendants adapt much better to the simulated environment. 


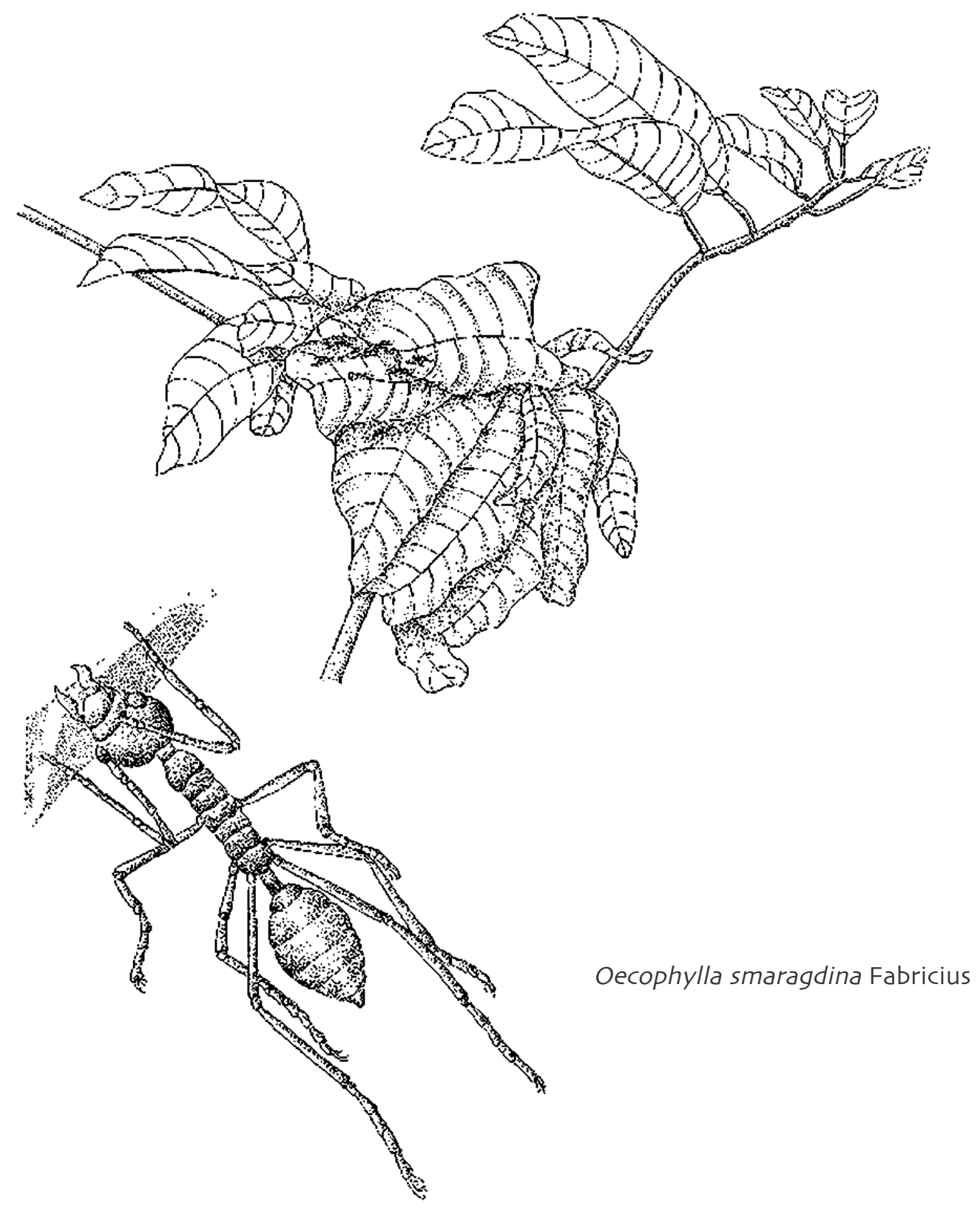

\section{Kroto, ant larvae and pupae}

Indonesian case by Nicolas Césard and Irdez Azhar 


\section{Singing praise for kroto: The bird food delicacy}

'Kroto' is the Javanese name given to a combination of larvae and pupae from the Asian weaver ant (mainly Oecophylla smaragdina). This mixture is well known to Indonesian bird lovers and local fishermen, with the ant larvae being popular as a fishing bait and also, as a dietary supplement to improve the performance of songbirds. Bird fanciers treat their favourite pets with the protein and vitamin rich kroto for the satisfaction of listening to their enhanced warbling or when preparing them to challenge other birds in singing competitions.

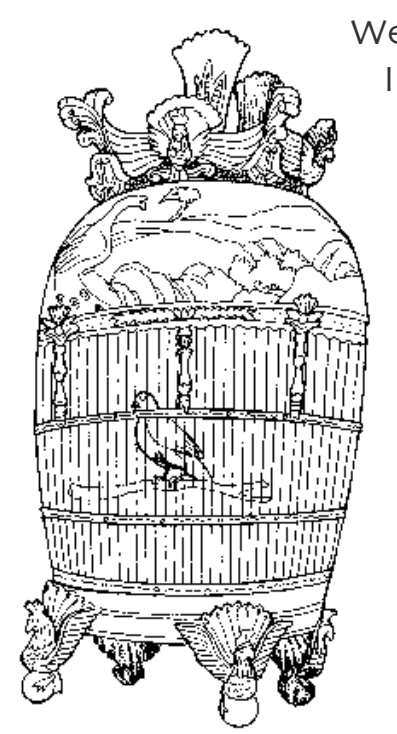

Throughout Java, caged birds sing beautiful songs, creating an atmosphere of peace and happiness within their owners' households. The breeding of songbirds also brings social recognition to the owners.

Weaver ants are found from India to Australia and throughout the Indonesian archipelago, within a wide range of habitats* including coastal areas, secondary forests* and plantations. They are well known for being aggressive predators and for building nests in trees. These ants can invade almost any type of tree but tend to prefer fruit trees, such as the jackfruit or mango. A given colony may occupy various nests in a single tree or even several trees. Located in one of the highest nests is the queen, whose eggs are distributed to the other colony sites nearby. Weaver ants' nests are among the most complex of ant nests, with the Oecophylla species using the well developed silk glands of their larvae to weave together a nest of living leaves - hence their name.

\section{Ant nest harvesting}

Throughout the year, kroto is harvested and sold on the islands of Java and Sumatra. Collecting kroto is a solitary job, which begins with the identification of host trees*. During the dry season, the resource is less abundant but during the wet season, the 'rice like' smaller larvae are more common, of a better quality and more highly valued. Because demand and competition for kroto has increased in recent years, some areas are being over-harvested and as a result collectors are finding fewer larvae. To fill their baskets they then work on a much shorter rotation of host trees, which in turn, affects the ability of the ant populations to recover. With less intense harvesting, the ants normally rebuild and recoup quite quickly. 


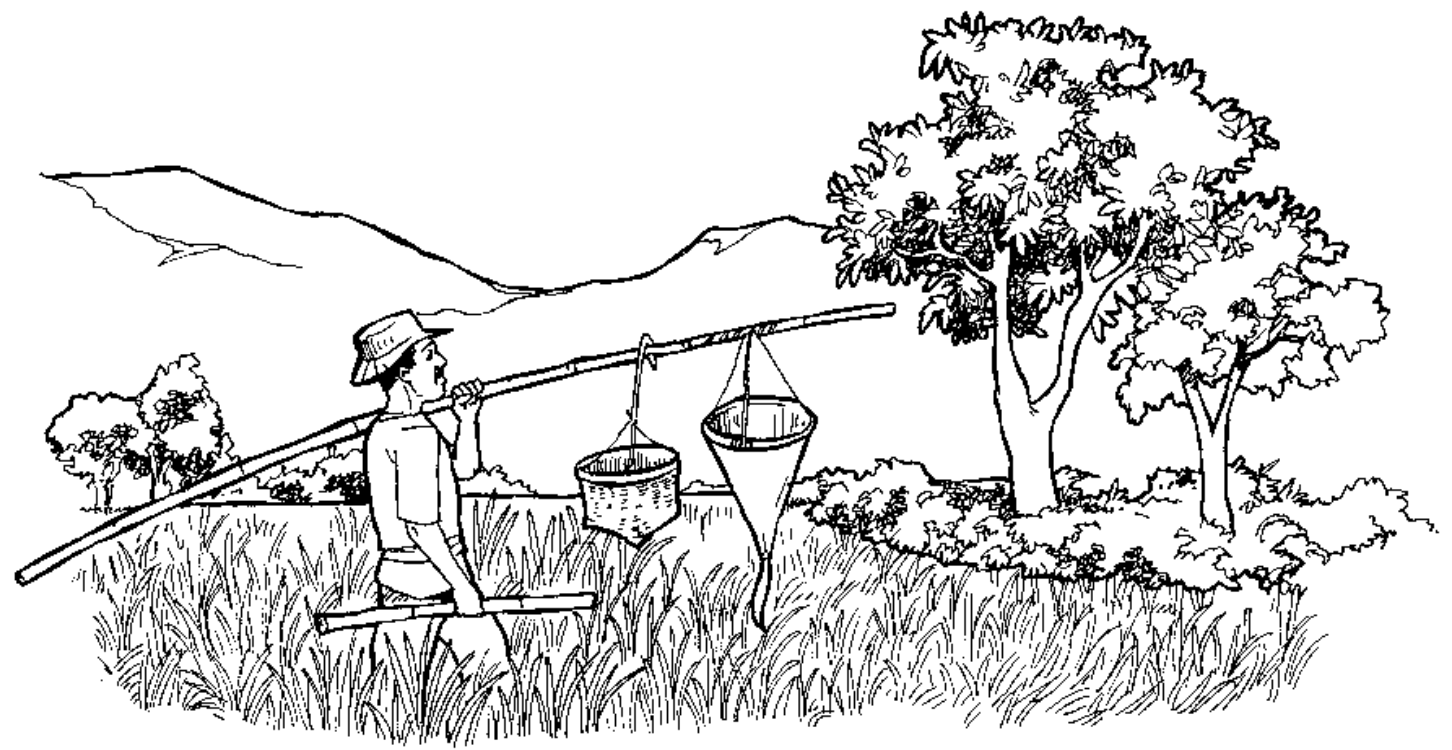

As the ants are very active during the day, collection tends to take place early in the morning, with a collector harvesting perhaps 6-8 trees within a 1 hectare area. A large nest of fresh leaves may contain 30-60 gm of larvae and during the high season (July-August), collectors may harvest up to $2 \mathrm{~kg}$ per person.

Nests that are too small, too high or otherwise difficult to access are likely to be left alone. However, collectors remember the locations for future expeditions, waiting a couple of weeks for the ants to change to more accessible sites or build new nests.

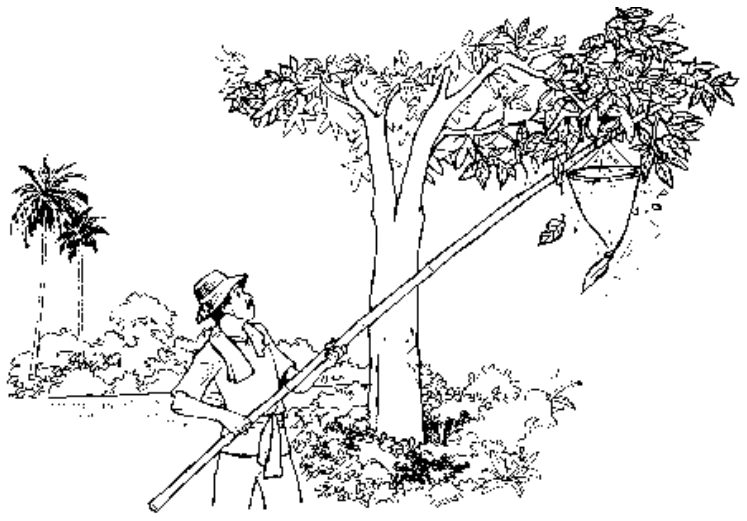

\section{Off to market}

Have you ever sat next to a passenger on a bus holding a mass of wriggling larvae?

As kroto can only be kept fresh for two days, traders often transport boxes into the city on a daily basis. Due to increasing demand and economic necessity, a local trader may take $10-30 \mathrm{~kg}$ a day to the markets. They also take some dried kroto, which is produced by collectors and can be kept for six months, but it sells at half the price of fresh supplies.

A bamboo stick more than $5 \mathrm{~m}$ long is used to pierce and burst open a nest, and the larvae are then shaken into a conic paddy bag hanging beneath the stick. Being careful not to be stung, the collector then repeats this process at several host trees. 


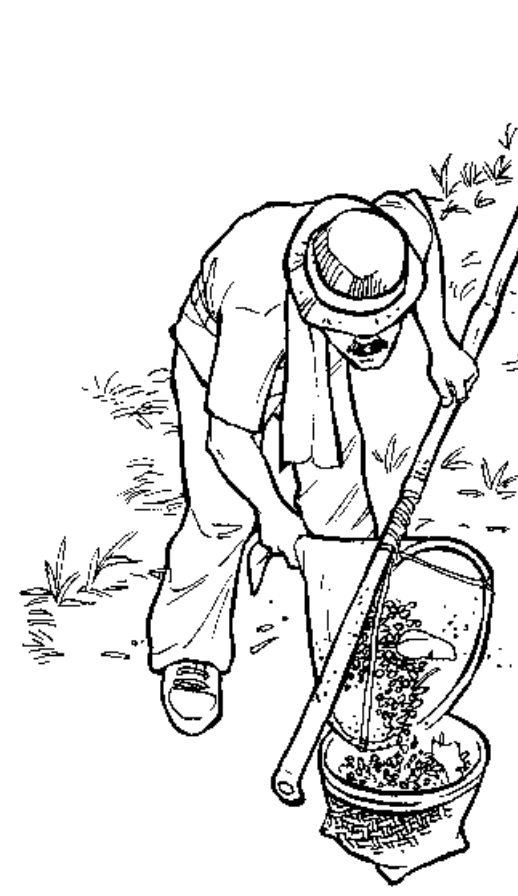

Up to $60 \%$ of the initial collection may be lost during transportation from the field to the house or during sorting. The fresh kroto requires little processing other than cleaning and grading.
The rapid deterioration of fresh produce and the need for immediate transport represent the biggest hurdles in marketing kroto. During the high season, traders pay collectors US\$ 1.20-1.40 per $\mathrm{kg}$ and then sell to merchants at US\$ 1.60-1.70 per $\mathrm{kg}$, leaving little profit after transport costs. The Jakarta markets sell around 100 $\mathrm{kg}$ of kroto a day at US\$3.50-5.00 per $\mathrm{kg}$, making the merchants the main beneficiaries in the kroto trade. To make more money, some collectors sell their daily harvests directly to small retailers, who are often willing to pay more for fresh kroto.

According to Muslim law, kroto might be regarded as a repulsive resource that should not be eaten either by people or animals and the money obtained from its sale is considered as 'dirty money'. However, for many collectors, kroto represents an important or principal source of income and is regarded as one of the few ways poor people can earn money from a free resource. Collectors use the money for subsistence needs (to buy food, clothes, school books, etc.) or to save for harder times. Farmers often collect the resource as well, as a way of earning some extra money in between the two rice harvesting seasons.

At the homes of local traders, who buy most of the harvest, collectors separate the remaining ants and debris from the larvae and pack the kroto into a $1 \mathrm{~kg}$ bamboo box.

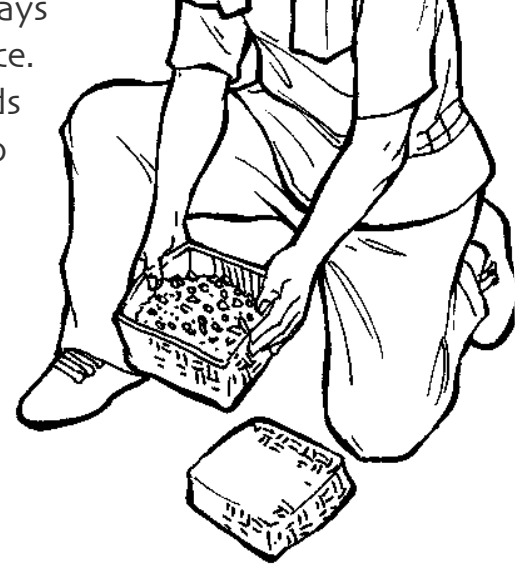




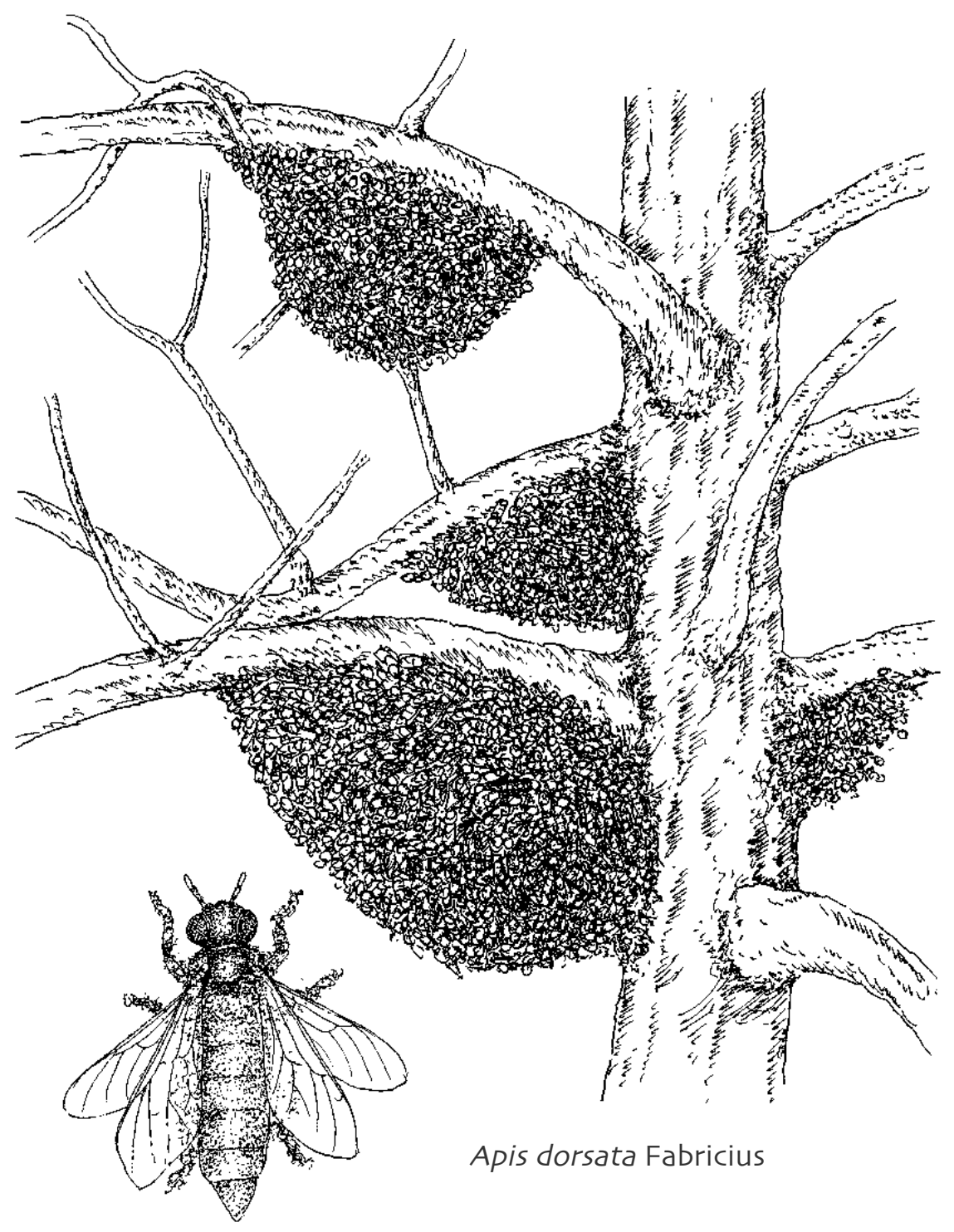

\section{Honey bee, honey and related products}

Philippine case by Jenne de Beer 


\section{Batak and the Bees: Wild honey in Palawan, the Philippines}

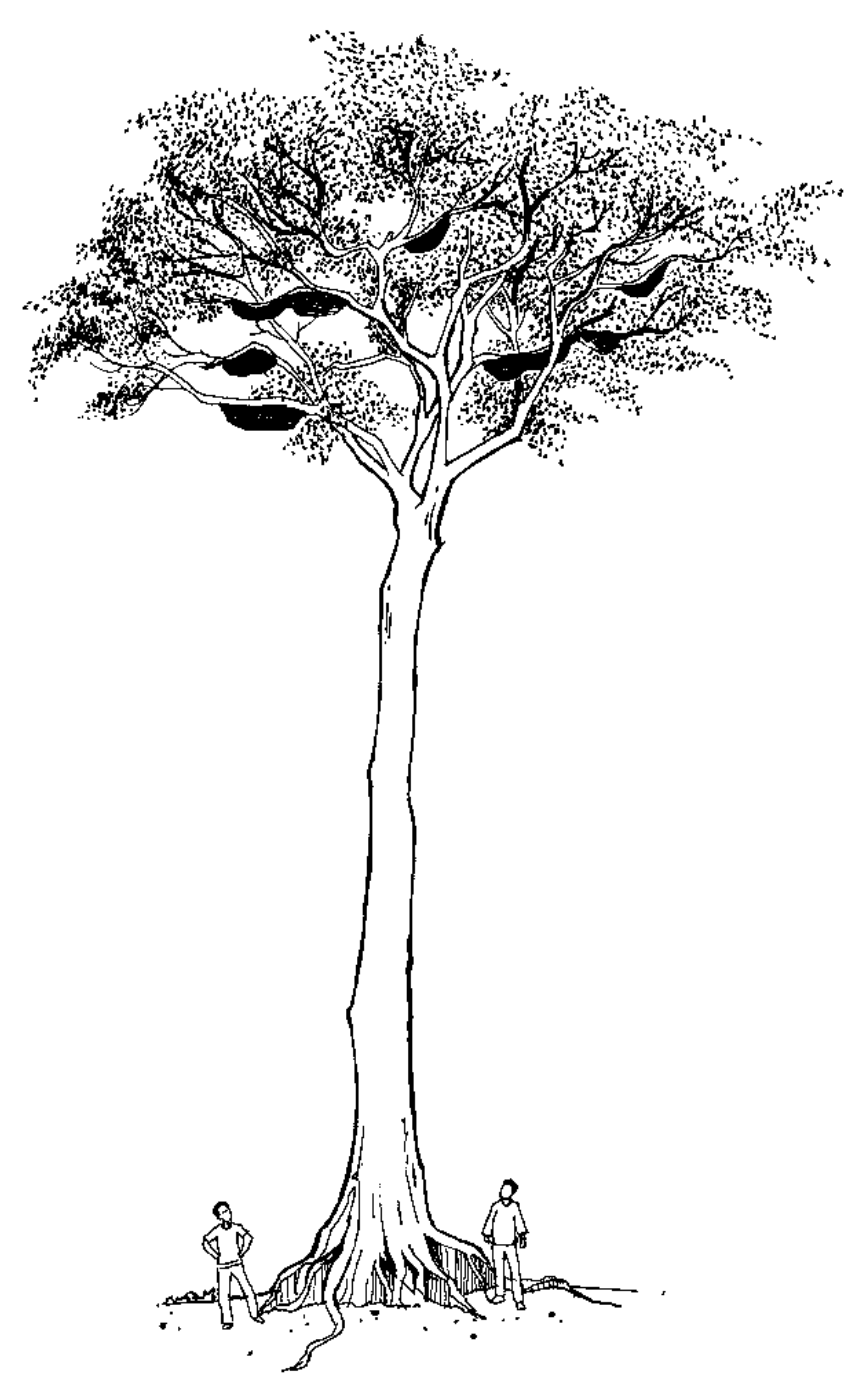

Apis dorsata bees enjoy nesting on 'koompassia' trees, where they feel safe from predators - except humans!
Mabuhay! Welcome to Palawan, the last frontier. For those who miss nature in Manila's traffic jams, Palawan is a paradise just a few hours flight away. This island, the fifth largest in the Philippines, is partially covered by one of the country's few remaining forests. Visitors to the island can return home with exciting memories, handmade rattan baskets and perhaps a bottle of the famous Palawan honey. But do they realise just how precious this dark liquid is? How it is harvested or how important it is for the local people?

\section{Bees in Batak culture}

Palawan honey comes from the wild and has a unique, strong and smoky taste - quite different to that of the mass produced honey from the European honeybee. It is made by 1-inch long Apis dorsata bees, also called 'giant bees' (or 'rock bees', as they like to nest on rocks or tall trees that are difficult to access). These bees occur in a large geographic range stretching from India to the Philippines and the harvest of their honey provides a good seasonal income for many forest people in Asia.

To learn more about Apis dorsata, it is best to speak to the Batak people, the smallest local ethnic group in Palawan (with only 400 Batak listed in the last census). The Batak are more dependent than other local groups on income from collecting honey as they have few other cash opportunities except for the sale of rattan, 'almaciga' resin and handicrafts. 
Bee hunting and honey harvesting lie at the heart of Batak culture. Once a year, the Batak perform their 'Lambay' ritual, in honour of the 'Master of the Bees' and his wife, the 'Goddess of the Rice'. According to the Batak, the Master of the Bees possesses human and animal features. During Lambay, plants, objects, colours, sounds and movements become tools to communicate with him. This ritual symbolically re-enacts all the steps involved in the human-bee relationship, from the arrival of the bees in the forest to the harvesting of honey. As part of the ceremony, the men perform a special dance, portraying the movement of the bees looking for nectar, and embodying the connection between people and bees.

\section{Harvesting}

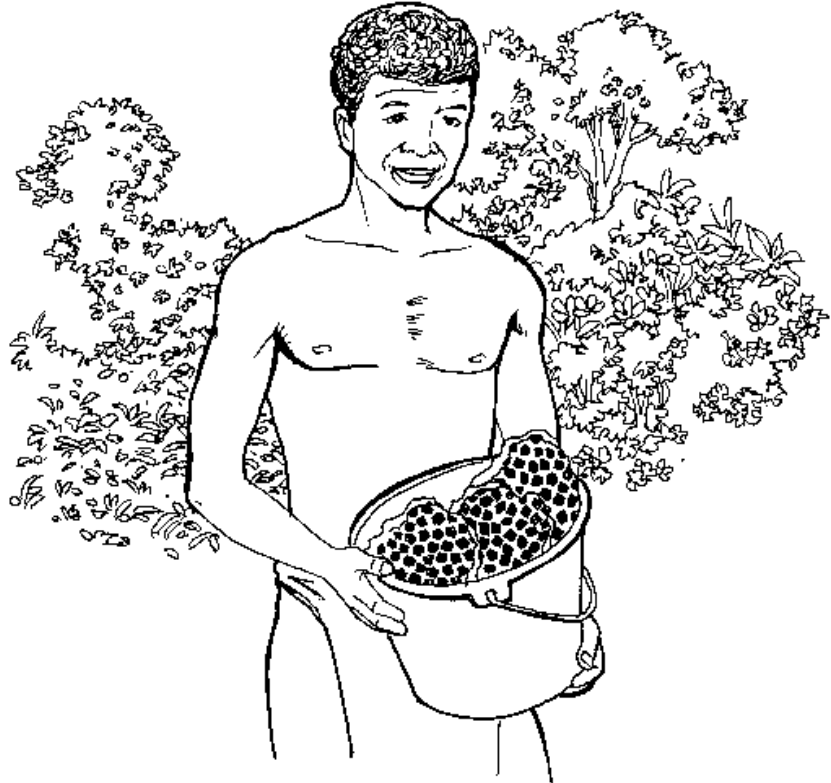

Upon recommendations from beekeeping specialists, local people are now using plastic containers to reduce the contamination that can affect the honey's quality.

Scientists still don't know much about the seasonal behaviour of $A$. dorsata. The Batak believe the insects live in another world until the Master of the Bees decides to scatter them throughout the forest. They then start to build their hives and collect nectar. Local specialists, often the shamans, know when the time is right for harvesting. Before collecting the honey, they pray and make offerings. They also carry special plants to reduce the insects' aggressiveness. Harvesting takes place at night because bees lose their sense of orientation in the dark and become less threatening. The Batak use a traditional method, which is not destructive, to drive the bees away. Collectors light torches containing a black resin that creates a lot of smoke. This disperses many of the bees but some kamikazes may still sacrifice themselves in attempts to protect their hive!

Imagine yourself surrounded by thousands of fighting soldiers in the dark, poised upon a narrow branch $40 \mathrm{~m}$ above the ground! Even the most experienced harvesters can feel queasy as they check the strength of their handmade wooden ladders. A hive is removed very carefully and placed into a basket. This is then lowered down with a rope and the process is repeated for the collection of more honey-comb. The heavy, honey-laden hives are then carried home. Some combs can reach $1.5 \mathrm{~m}^{2}$ in size and weigh around $20 \mathrm{~kg}$. The biggest 'koompassia' trees - which the bees tend to prefer - may host up to 100 colonies (holding perhaps 500 litres of the precious honey). 


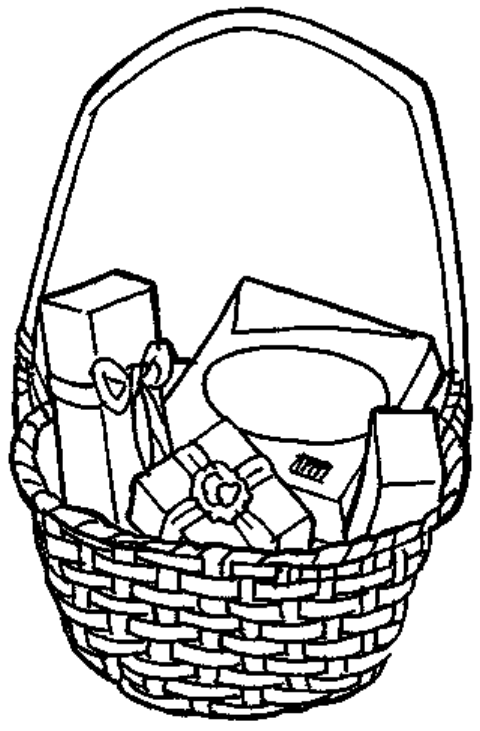

Wild Palawan honey is also used in skin care products, like soaps and beauty masks.

\section{Conserving a valuable resource}

For many years, local ethnic groups have faced serious competition from outsiders for the harvest of forest products like almaciga and rattan. This has not occurred with honey though, as its collection requires very specific skills. However, bee hives are threatened by other factors, such as forest fires and landscape changes.

The indigenous organisation NATRIPAL (United Tribes of Palawan), which is based on the island and includes the Batak as members, has been involved in an effort to improve the trade in forest honey for some years now. In the initial stages, the organisation sought valuable lessons from the experiences of others in the region. For example, it learnt from the Vietnamese how to improve the quality and pureness of honey. The Non-timber Forest Product (NTFP) Exchange Programme for South and Southeast Asia (of which NATRIPAL is a founding member) facilitated input from the Bee Research and Development Centre of Vietnam.

Activities were directed at:

1. Quality improvement through:

- Reducing moisture content to acceptable levels

- Implementing measures to attain product purity and prevent contamination

- Introducing grading and differentiated pricing according to quality

2. Developing attractive and recognisable packaging and labeling

3. Exploring and opening up niche markets.

As a result, NATRIPAL has made steady improvements in its marketing and in the 2003 season, sold 300 per cent more honey than the year before! It buys honey from harvesters for US\$ 6.25 for $20 \mathrm{~kg}$ and then sells it locally to tourists and others in metropolitan Manila via the Upland Marketing Foundation (UMFI).

Hopefully the Master of the Bees appreciates all this effort and will send more of his children down to the forest! 


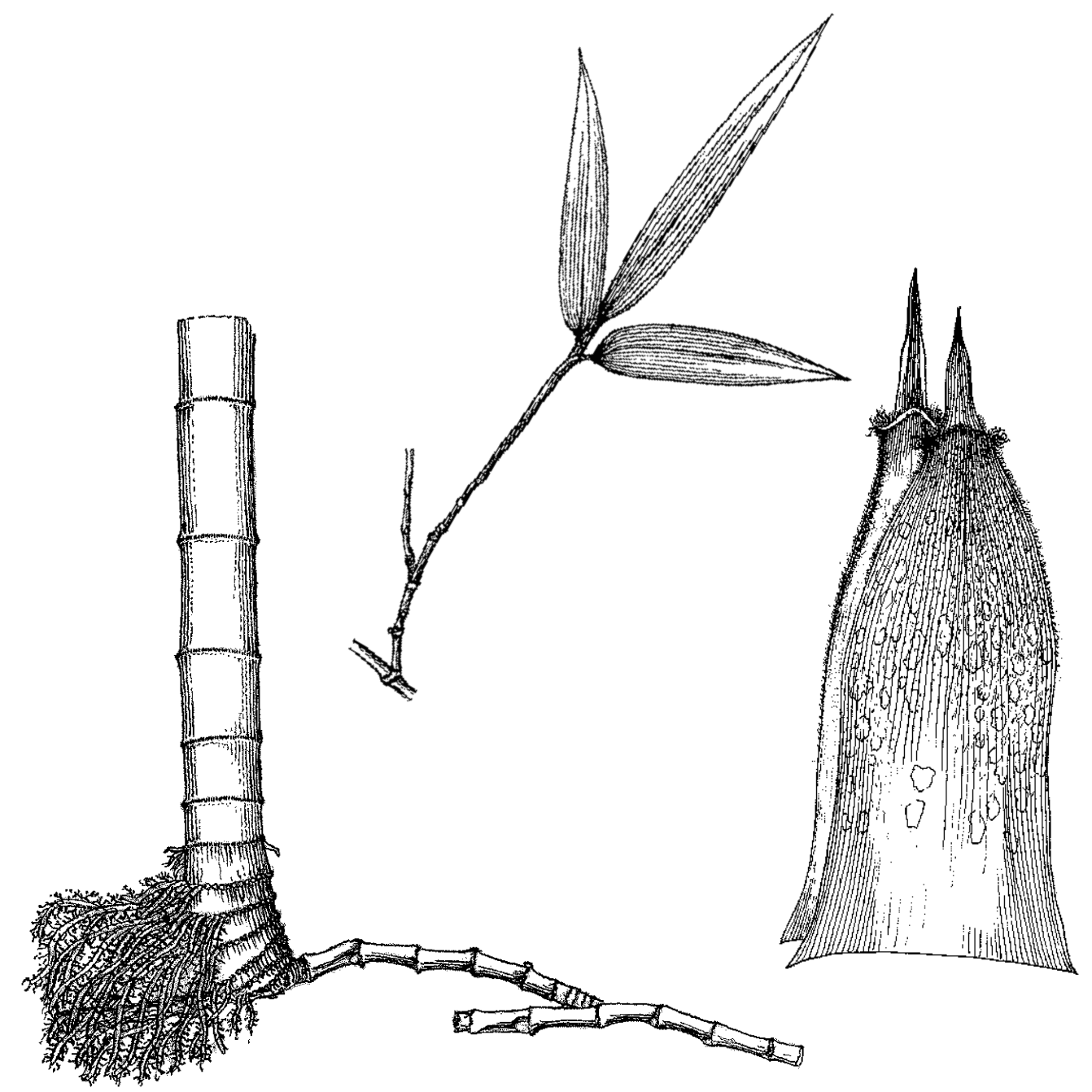

Phyllostachys heterocycla var. pubescens (Mazel ex J. Houz.) Ohwi

\section{Bamboo}

Chinese and Vietnamese case by Fu Maoyi and An Van Bay 


\section{Bamboo: Green gold in China and Vietnam}

Bamboo belongs to the grass family and is the world's largest plant in that family. There are more than 1,200 species of bamboo and most of them are found in Asia. This beautiful plant, with its strength and flexibility, has infinite uses and aesthetically, has long been a source of inspiration in Asian literature and the arts. Indeed, bamboo is a recurrent theme in poems, songs and paintings. According to one famous Chinese poem: "It is quite possible not to eat meat, but not to be without bamboo."

Shakuchachi - the traditional Japanese bamboo flute. Its four holes are sufficient to produce a complete range of sounds.

Bamboo is a natural part of life, from the cradle to the tomb. In China and Japan bamboo knives are used to cut the umbilical cord at birth and once deceased, the body of a dead person rests upon a tray made from bamboo. This plant is deeply rooted in people's daily lives, and their culture - which is even referred to as 'bamboo civilization' or 'bamboo culture', especially in South East Asian countries (like China, Korea, Vietnam and Japan).

Bamboo has countless uses. In 1853, when Japan still followed a strict policy of isolation, more than 5,000 Japanese soldiers waited on the shoreline of Edo Bay for American intruders, armed with spears, bows and muskets. The fierce samurai were clad in lacquered bamboo armour. Today, in rural areas, bamboo is used to dam paddy fields and to make all manner of items, from housing to animal shelters, fencing, ladders, birdcages and woven mats. It is also used to create tobacco pipes, picture frames, baskets and kitchen utensils, not to mention its important role as a fuel.

Drawing on a long history of use, bamboo has since become integrated into the modern technological world. Bamboo factories now produce many types of goods, from high quality paper to chopsticks, woven baskets, handicrafts, furniture, plywood and floorboards. Some of the newer bamboo-based products include soaps, water purifiers, pain relievers and lotions, which are now being introduced into Europe and the United States of America. Entrepreneurs refer to bamboo as 'green gold', recognising its increasing 
economic potential. China alone sells around US\$ 2.4 billion worth of bamboo products each year.

In Vietnam, the economic importance of bamboo is also growing. In addition to its everyday, local applications, bamboo is used to make handicrafts for export to Japan, Hong Kong, Taiwan, Europe and the United States of America. Edible bamboo shoots are also collected and sold to middlemen, who transport them to the city markets, while the non-edible, fibrous part of the harvest goes to a paper mill. The resultant low quality paper is exported to Taiwan as 'fake money' for burning during prayer. Indeed, 'green gold' has many

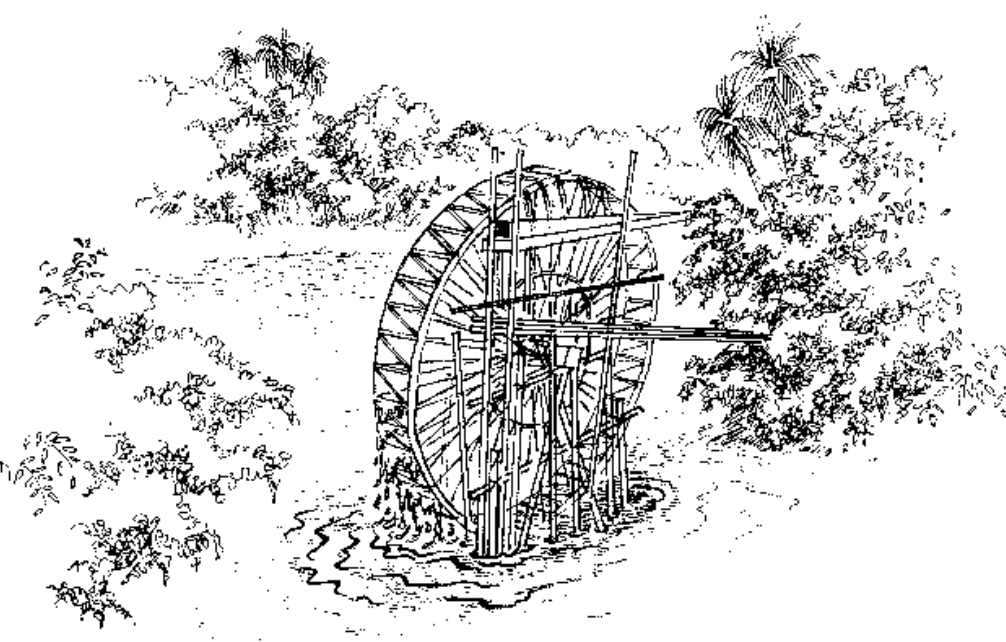

Bamboo water wheels are used in the irrigation of paddy fields. values, for many different people.

\section{Bamboo in China}

China is the richest bamboo producing country in the world, with over 500 bamboo species and 4.2 million hectares of bamboo plantations and natural stands. In the past, the manufacture of bamboo products was done by specialised artisans. However, during the past 20 years, the Chinese bamboo industry has opened to all sectors of society.

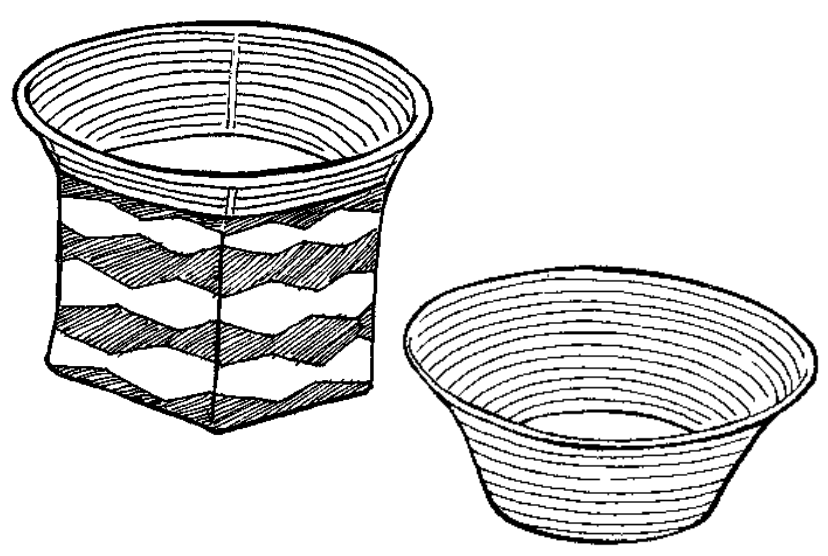

In Anji county, in the south of China, one of the country's biggest bamboo growing and processing regions, the industry's growth has been striking. Between 1980 and 1998, it expanded at a rate of about $35 \%$ each year. Here, the bamboo culms* and shoots provide a major source of income for farmers and many others working in the bamboo industry. Private investment and management rights have proven to be major catalysts. In 1998, there were 18,900 workers in the bamboo industry in Anji, creating a production value of US\$ 107 million (with exports accounting for almost half of this figure). The value of one bamboo culm is about 


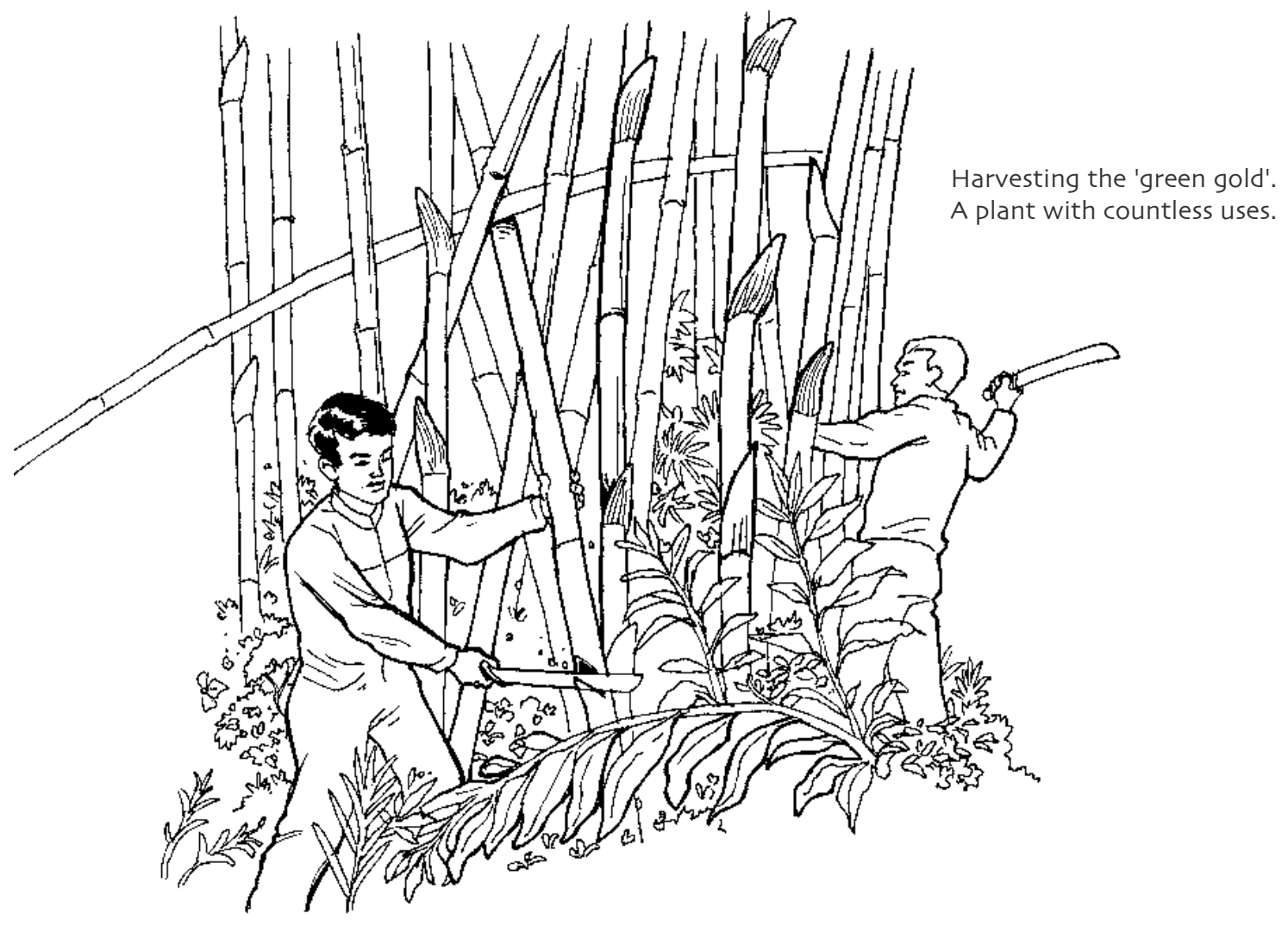

US\$ 0.90-1.00, while the value of the final bamboo products varies, from around US\$ 2 per culm for chopsticks or mats, up to US\$ 13 for certain value added handicrafts.

Over the years, rising bamboo production levels have called for increasing amounts of raw material. In Anji, bamboo is predominantly harvested from plantations, mainly growing a bamboo species locally known as 'maozhu' or 'moso bamboo' (Phyllostachys heterocycla). Like other bamboo plants, this species is fast growing and easily cultivated.

In Anji, moso bamboo has been grown for centuries and currently represents $60 \%$ of the forest area - a percentage that is rising due to the expansion of plantations. However, this intense cultivation uses large amounts of fertilisers and pesticides, with negative environmental effects. The use of chemicals and monocultures*, along with moso bamboo's tendency to rapidly and vigorously spread out, is threatening natural forest areas and local biodiversity*. On the other hand, bamboo plantations can also have some positive ecological effects, for example when established on eroded or degraded lands, and they can contribute to soil and water conservation. Today, an increasing level of attention is being paid to addressing the environmental damage associated with bamboo plantations and also, to conserving biodiversity*. 


\section{Bamboo in Vietnam}

Bamboo grows right across Vietnam and is one of the country's most important forest products, providing food, raw materials and shelter. In the Cho Don District of North Vietnam, one of the most important commercial bamboo species is Neouhouzeaua dullooa, locally called 'nua'. Up until 1980, bamboo was mainly used for the construction of houses and other domestic purposes. The volumes traded were initially limited, with the transport of bamboo largely being confined to the river systems. In recent years however, the poor road system has been improved and the demand for raw materials for paper and handicrafts has increased, stimulating further trade.

Many local farmers earn more than half of their cash income selling the bamboo culms and shoots. The dry season (August-February) is the preferred harvesting time for culms as high humidity during the rainy season increases the chances of insects damaging the cut culms. The collection of young bamboo shoots however, takes place during the wet season, an activity that mainly women carry out, earning themselves an important source of seasonal income.

The nua regenerates quickly after the mature culms are harvested, however the over-harvesting of new shoots can have an adverse impact. Ideally, only shoots growing close to mature culms should be harvested since these would have insufficient space to grow into straight, mature culms themselves. However, families in need of quick cash often have little choice but to harvest and sell as many shoots as possible. This results in less harvestable, mature culms - which

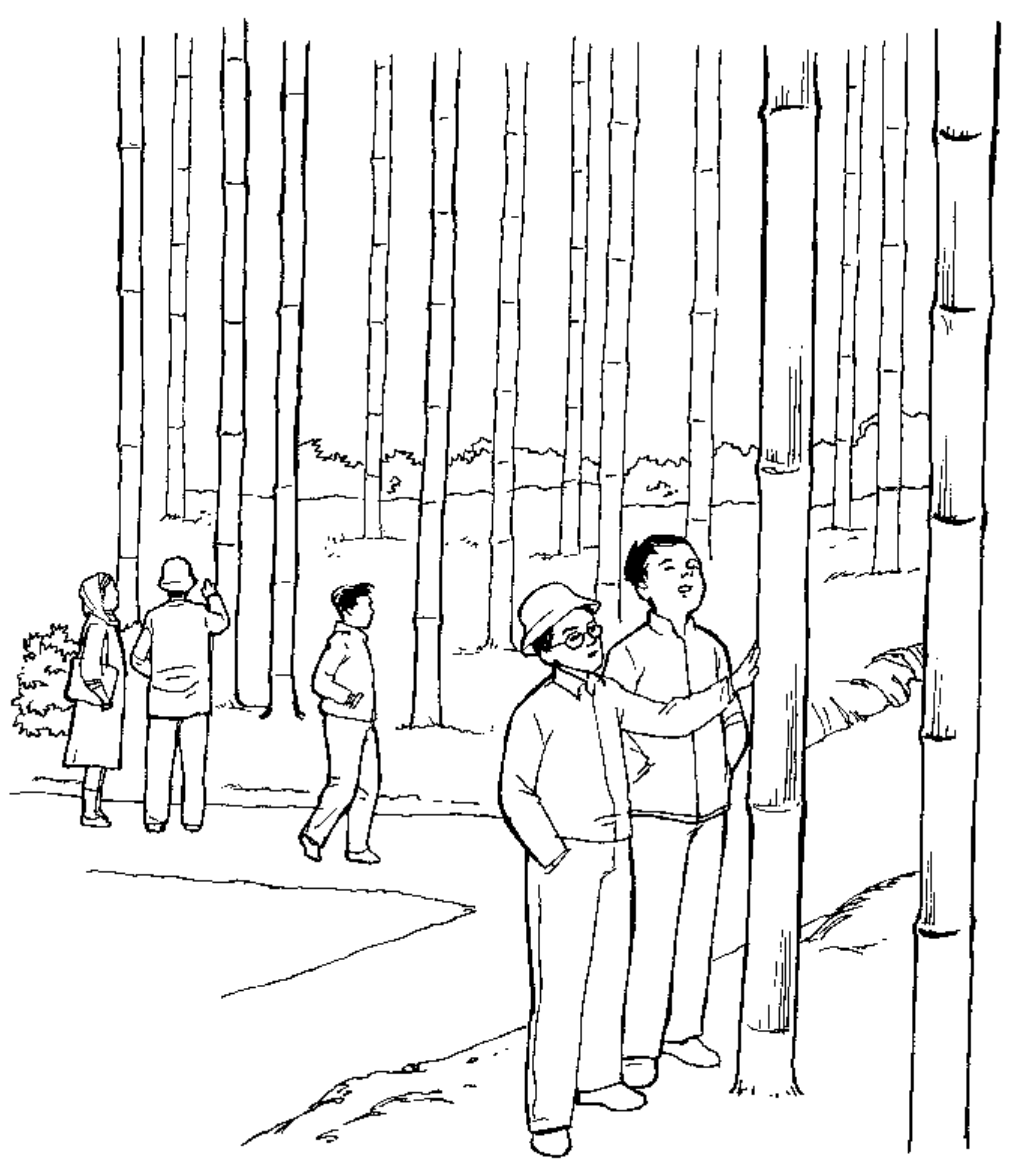

Bamboo plantations that stretch for kilometres attract the attention of hikers and tourists. The beautiful straight, green canes, growing as tall as $20 \mathrm{~m}$, have long been a source of inspiration for Asian poets and artists. In Anji, there is even a popular bamboo botanical garden and museum (established for both tourists and researchers). 
are ultimately, much more profitable. Whereas ten shoots fetch about US\$ 0.007 at the farm gate, the price of one culm is at least US\$ 0.03 .

Nua shoots are commonly used for food and are mostly consumed within the country. Bamboo culms on the other hand, are used to produce handicrafts, furniture and paper, much of which goes for export, increasingly to markets like Europe and the United States of America - earning valuable national income.

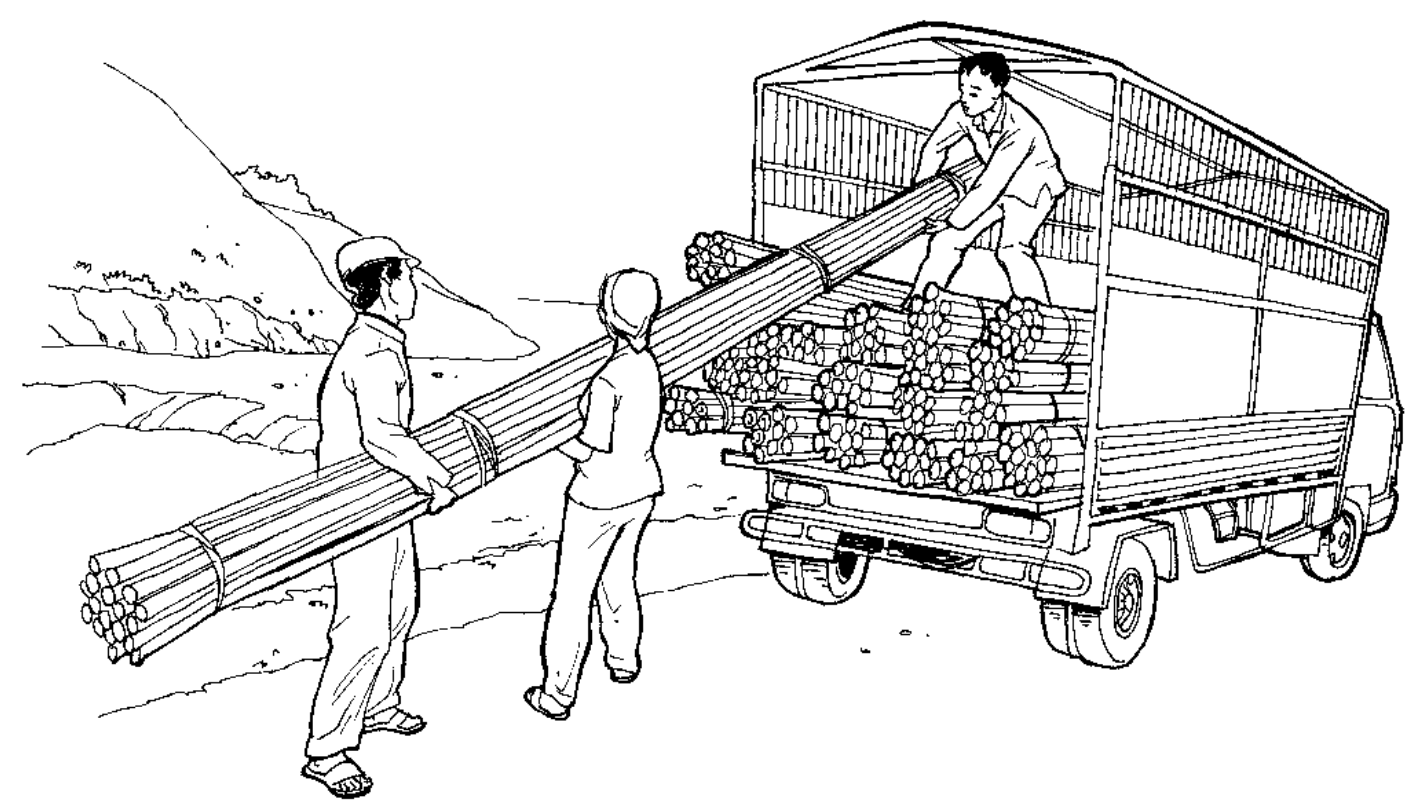

Traders usually buy bamboo from local households and transport it to a central storage area near a roadside or river. From there, middlemen organise its transfer by truck, to paper factories in other provinces or to villages where bamboo handicrafts are manufactured. 


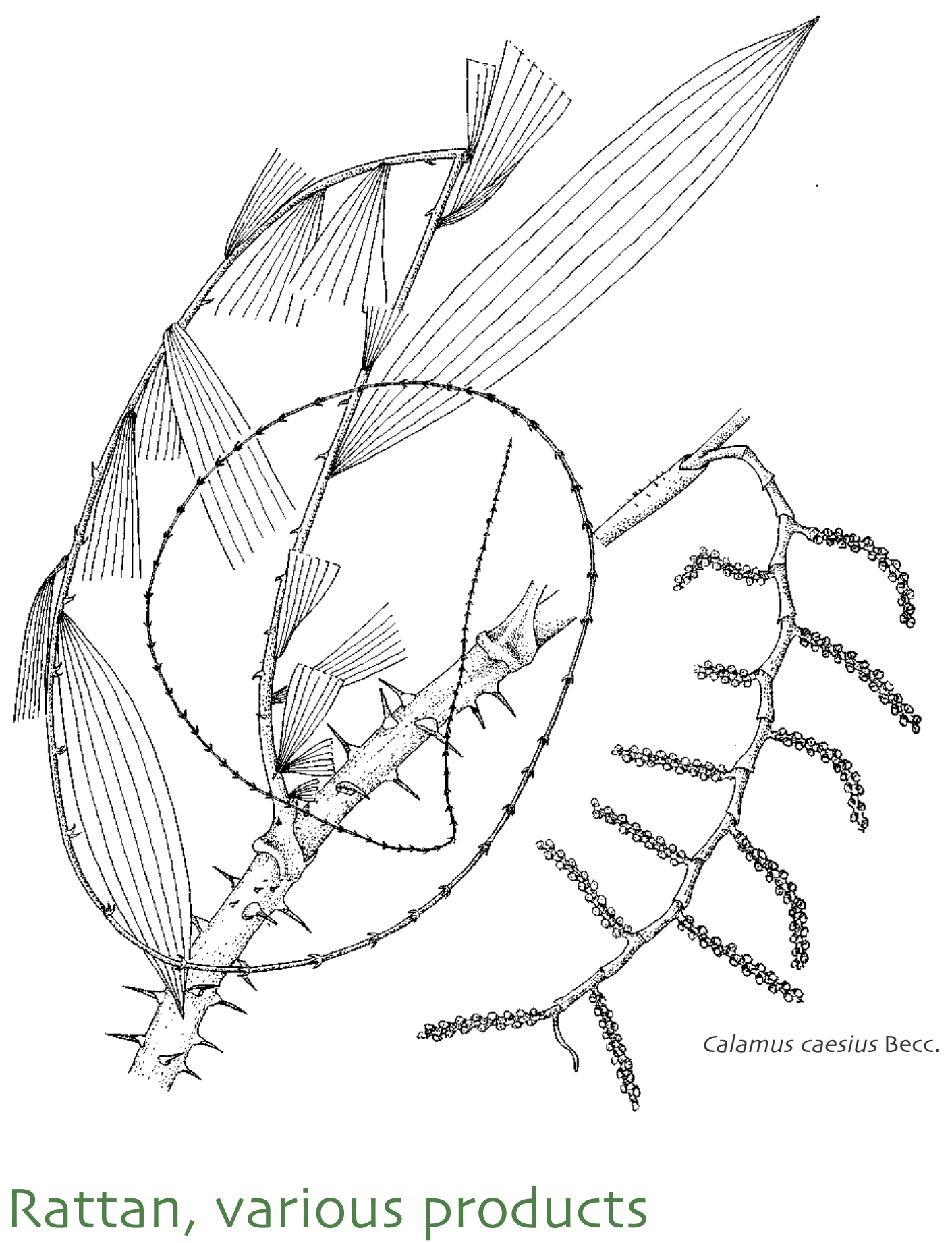

Indonesian and Philippine cases by Fadjar Pambudhi and Honorato G. Palis 


\title{
Rattan: The changing fortunes of a versatile forest plant
}

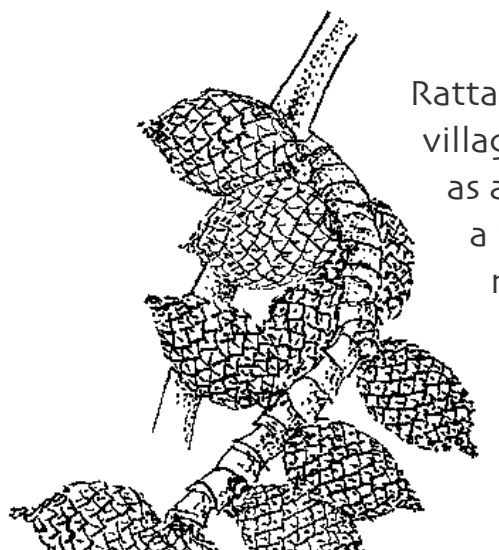

Rattan is an integral part of the life and culture of Asian people living in both villages and cities. In rural areas, rattan is cooked as a vegetable and served as a side dish and its strong, durable stems (or canes*) are used for making a whole range of things - from fences marking property lines to building materials, baskets, ropes and tools. Meanwhile, in Asian cities (and many other parts of the world), rattan furniture, mats and decorations can be found in countless homes, creating a fresh, relaxed look, with natural appeal. The plant itself however, is not so inviting!

Rattan, a spiky member of the palm family, climbs all over nearby plants and trees with single or multiple stems that can grow more than $100 \mathrm{~m}$ long. Like the leaves and whip-like branches, the stems are covered with spines, thorns, bristles or hairs. This makes rattan a difficult plant to harvest and it is not unusual for harvesters to get injured while trying to pull the tightly clinging rattan away from its support trees or when removing the thorny outer skin with a machete. However, the myriad uses of this forest product and its potential to generate income provide the motivation for overcoming the challenges of harvesting.
\end{abstract}

Indonesia and the Philippines are two of the key commercial rattan producers in Asia, earning important income from the harvesting and processing of rattan. Although market conditions and prices are constantly changing, rattan remains a fundamental resource, for both commercial and subsistence uses, especially for rural people.

\section{Rattan - its harvesting and processing}

There are around 650 species of rattan, exhibiting wide variation in growth form, size, ecology and commercial quality. In Palawan, the Philippines, rattan is extracted from old growth and residual forests, while in Kalimantan, Indonesia (where about 146 rattan species occur) canes are harvested mainly from the wild, with cultivated supplies from 'rattan gardens' accounting for around 15\% of the total production.

Given the nature of the plant, harvesting rattan canes is tough work. After they are carefully cut from the plant and scraped with a machete, the canes are carried back to a storage point and stacked vertically to dry. This can take from 3-14 days, depending largely

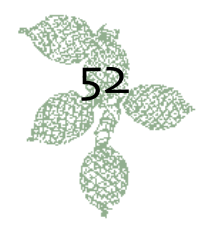




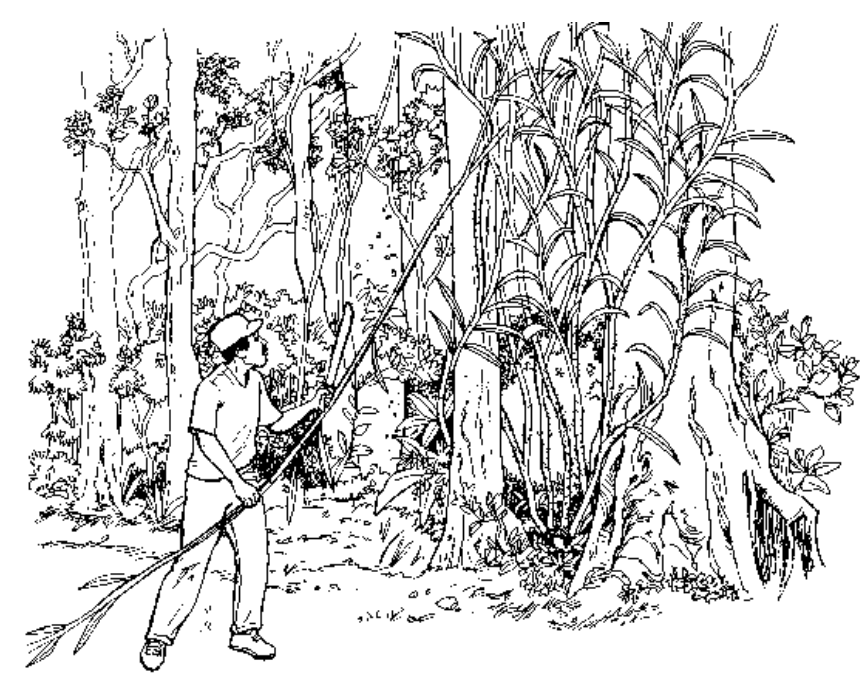

The spiky, clingy nature of rattan presents a challenge when harvesting. on the weather. Drying lessens the moisture content and reduces susceptibility to stain fungi and powder-post beetles, the two most common pests affecting stem quality. If the canes are to be stored for some time, they are also boiled in oil fumigated with sulphur.

In Indonesia the rattan is transported, by river or road, to market. In the Philippines, the dried rattan is often taken to a warehouse first for resizing and rebundling. Crooked stems are straightened with jigs and hand devices, while scraping is done with a machine, metal scraper or cut glass to create a smooth finish and uniform diameter. Much of the stock is then loaded into $6 \mathrm{~m}$ containers bound for Manila and further

processing - e.g. furniture manufacturers bend the rattan stems into desired shapes with heat from a blow torch or steam saturation. Commercially, the large canes are used in the construction of frameworks for furniture and other large items. The small canes (with diameters less than $18 \mathrm{~mm}$ ) are used in the production of mats and handicrafts, after the outer layer has been peeled off.

\section{Rattan in Indonesia - a long and complex history}

The history of the Indonesian rattan industry demonstrates how irregular and unstable the market conditions for some forest products can be. In Kalimantan, one of the main harvesting regions, rattan was indispensable as a binding material in traditional construction throughout the colonial period and even until the 1960s. This was at a time when iron was scarce and nails were a luxury item. During the 1970 s and 80s, rattan also became economically important, both locally and nationally. Calamus caesius (known locally as 'rotan sega') was used to produce a special handmade carpet (lampit') design originating in Kalimantan. Rattan was also sent to the Indonesian island of Java and to other countries in the region as raw material for their furniture-making and handicraft industries.

However, in 1988 the Indonesian government banned the export of raw and semiprocessed rattan in an effort to regulate sales, promote domestic processing and capture a greater share of rattan profits. Unfortunately, this policy was counter productive and both 

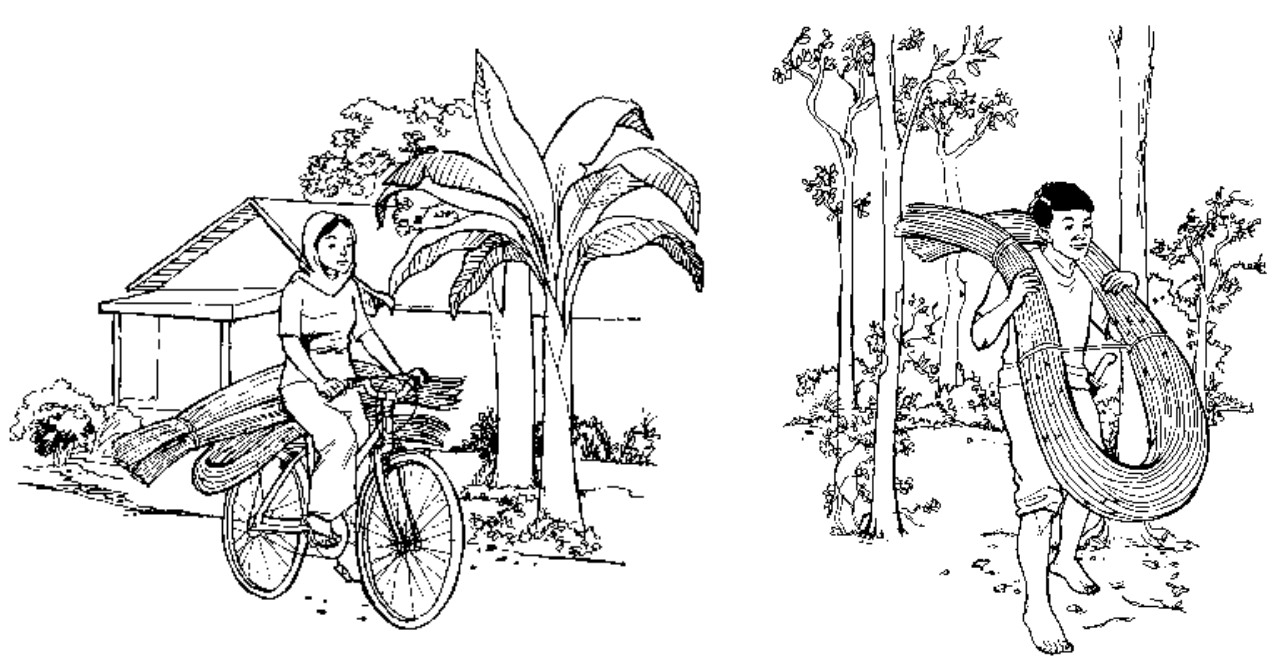

Rattan is an important resource for rural people in countries like Indonesia and the Philippines.

the value of lampit exports and the prices farmers received for their rattan declined. This downturn affected many people, especially harvesters, who were accustomed to ups and downs but understood little about the reasons behind the sudden price collapse. Over the next decade, as prices didn't improve, farmers increasingly looked for alternative sources of income, from products like oil palm.

During the ban however, the number of processing factories increased in 1989, from three to 42 units. These processors started to produce finished products and furniture - whereas the previous factories had produced mainly semi-finished products. While the overall volume of rattan products being produced has decreased, there is an indication that the value obtained for each unit of volume has increased.

In recent years, land reforms and fires have destroyed many rattan gardens and harvesting sites, and at the same time, demand has decreased. Rattan was once a forest product that, along with other products like resins and gums, provided a main source of income for local villages. It has since come to constitute a more marginal financial activity. However, despite the fluctuations in prices and markets, rattan continues to play an important role in the lives of many Indonesian people, especially the Dayak of Kalimantan.

\section{Rattan gardens}

Most rattans grow wild in the forest but in Kalimantan, several species are cultivated in rattan gardens, having become part of the traditional cycle of rice cultivation. The Dayak, who are experts in rattan cultivation, describe this plant as 'a gift from God'. No one quite knows how the Dayak came to cultivate rattan. Some documents date it back to the mid-

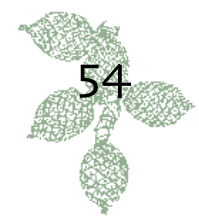


nineteenth century, when rattan started to be traded internationally. Elders recount that the Sultan of Kutai encouraged rattan cultivation and it was sometimes planted in swidden fields* close to dwelling places, mainly to meet a village's own needs.

Dayak farmers plant rattan seeds or seedlings, mainly Calamus caesius, in newly created agricultural fields (or 'ladang'). Their main agricultural crop is upland rice but food crops like maize, cassava and banana are also planted. The young rattan plants are protected in the ladang and when farmers shift to a new plot 1-2 years later, the rattan is left to grow up with the secondary forest* vegetation, creating a 'kebun rotan' or rattan garden. The growing rattan requires little attention - only 7-8 days in the first year plus small inputs of time for weeding and protecting the young plants. Once established, the rattan can then be harvested periodically, using simple technology, for some decades.

The rattan gardens are found as green signposts throughout the forest, marking former rice fields, and providing habitat* for many plants and animals. The gardens also define the land rights of families or individuals. Despite the existing low demand and prices, these rattan-enriched forest gardens continue to serve as 'bank accounts' which can be converted to cash for emergencies or for major investments, such as a child's education.

\section{Rattan in the Philippines}

As in Indonesia, rattan in the Philippines is an important component in rural people's daily lives. For the Batak, one of four remaining tribes on Palawan Island, rattan contributes to people's livelihoods and is one of the traditional materials used for building wooden houses. Many parts of the plant are useful - wild pigs eat the fleshy portion of the fruit (sarcotesta), the bud or inner portion of the stem, when roasted, serves as a good vegetable dish, while the freshly cut stem contains drinking water. The Batak obtain their main income from harvesting forest resources like rattan, honey and resin, while the weaving of baskets and mats provides additional income. Their most important commercial rattan species is Calamus merrilli, locally known as 'palasan', with harvesters receiving around US\$ 0.01 for a $1 \mathrm{~cm}$ diameter cane and up to US\$ 0.12 for a $2.5 \mathrm{~cm}$ diameter cane.

In some areas of the Philippines the fruits are more important than the rattan poles. For four months every year, people in the northern upland provinces collect the small, dark yellow rattan fruits for eating raw or preserving. The plants start to bear fruit in their seventh year and continue fruiting for decades. Once the plant becomes unproductive due to old age it is cut and used for making handicrafts.

In the Philippines, the levels of rattan harvesting have been increasing but this continual extraction has led to dwindling supplies, as in Indonesia. One of the main issues relates to the distance from villages to rattan harvesting sites and marketplaces - and the greater the distance, the higher the cost of transportation. In some cases, the selling prices hardly cover

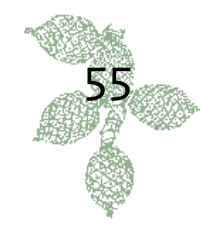


the cost of harvesting and transport. Other problems include the lack of appropriate postharvesting technologies and the high dependency of harvesters on brokers and traders, who sell the rattan and take a slice of any profits.
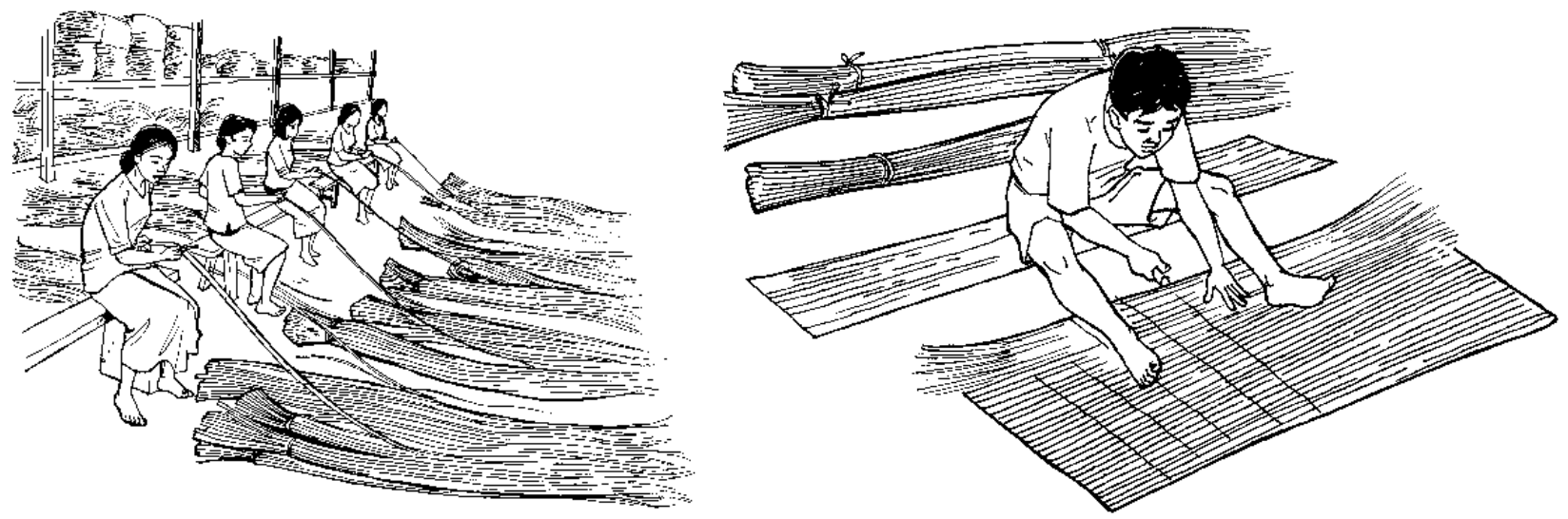

By 1987, the rattan mat industry in South Kalimantan was at its peak and employing more than 4,000 people. Rattan demand and prices reached unprecedented highs and to secure supplies, traders would offer villagers cash advances and consumer goods. This boom however, was to be short lived.

\section{Future paths for rattan}

In both Indonesia and the Philippines, the efforts of local people, the government and nongovernmental organisations have focused attention on supporting cultivated rattan, based on local management knowledge. In 1999, NATRIPAL (the United Tribes of Palawan) organised for indigenous people from Palawan to travel to Indonesia in order to meet with the Dayak of Kalimantan and learn about their traditional rattan planting techniques. In the process, knowledge and experiences about rattan management, harvesting and cultivation were exchanged between both groups.

Other joint efforts among rattan cultivators and harvesters in both countries include the organisation of workshops to estimate sustainable harvesting rates. This approach is based on local people, in collaboration with researchers, applying appropriate methods to collect information. Additional initiatives include exploring certification measures for traditional rattan gardens, and the labelling of forest products as originating from well managed sources. A variety of different strategies are being explored or implemented in order to foster sustainable management* practices and secure a long term future for this important forest product. 


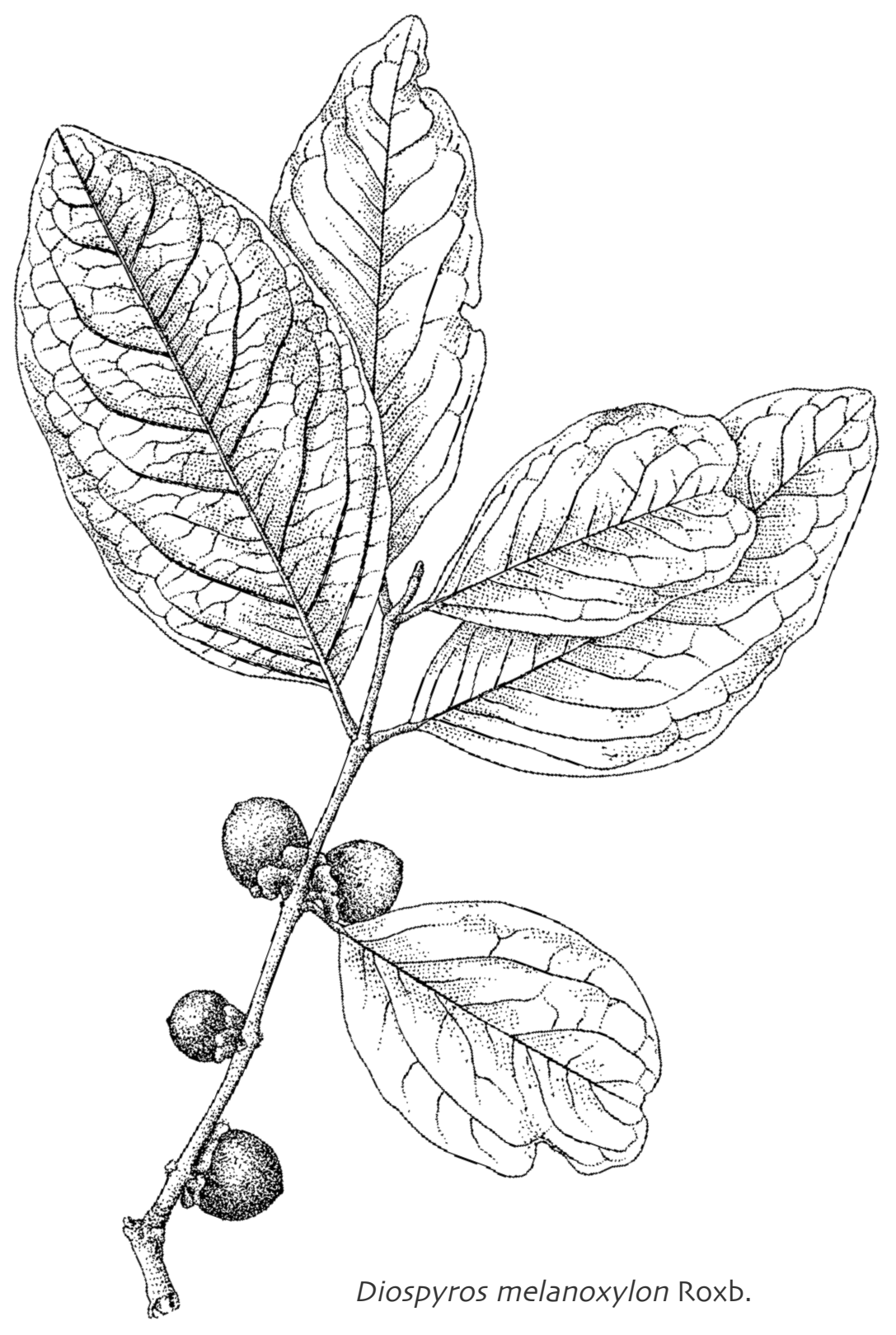

\section{Tendu, leaves for cigarettes}

Indian case by Arvind A. Boaz 


\section{Tendu: Distinctive aroma from India}

On the street corners of India and neighbouring Pakistan, Sri Lanka and Bangladesh, the distinctive aromatic blend of tendu leaves and tobacco wafts into the air. While most tendu cigarettes are consumed in India, smokers of 'beedis' can also be found as far afield as the Arab countries, the United States of America and Europe. For over half a century, tendu leaves have been used to wrap tobacco in the large scale manufacture of these tiny Indian cigarettes. The tendu leaves are popular due to their fine aroma, ease of rolling and smooth, continuous burning properties.

\section{State control and co-operatives}

Tendu leaf collection has become a seasonal way of life for many harvesters, with flow-on benefits for people involved in the transportation and storage of leaves and the rolling and trading of the cigarettes. In 1964, to improve conditions, the Government established state control over tendu collection and trade and in 1989, co-operatives were formed, with the collectors' families as members.

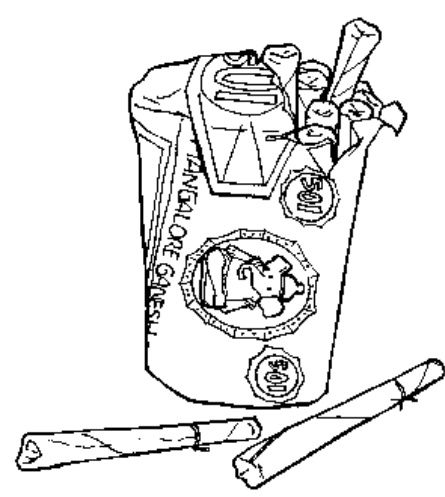

Tendu leaves are picked from a medium sized, native tree (Diospyros melanoxylon), found in abundance in Central India. Most of the harvest comes from trees growing naturally in open forests and waste lands, particularly in the states of Madhya Pradesh and Chhattisgarh. To obtain the best quality leaves, villagers prune the plants in spring (March) and then harvest the fresh growth from May to June, before the leaves turn leathery.

Tendu bark, fruits and leaves are also used in traditional medicine and the sweet, round summer fruits can be an important part of the diet for certain people and also, birds and mammals, which disperse the seeds as well. Pruning and intensive commercial collection of leaves however, can lead to a reduced fruit supply. Customary rules governing access and management of tendu leaves generally help prevent over-exploitation although competition in larger communities can lead to less respect for these guidelines. Fires to stimulate the growth of new root suckers can also have adverse effects on other forest trees and animals. Educating collectors about proper pruning and harvesting practices could lead to both better management and returns. 


\section{Income for many families, in different parts of India}

Throughout Central India, a large number of mainly poor families pick tendu leaves during the summer when little other work is available. Every year, the two Central Indian States of Madhya Pradesh and Chhattisgarh produce more than 4.5 million 'standard bags' (each containing 50,000 leaves). In 2002, the government purchase price was around US\$ 9.50 per standard bag. Filling three to four bags during the season, each family earns around US\$ 32 - a

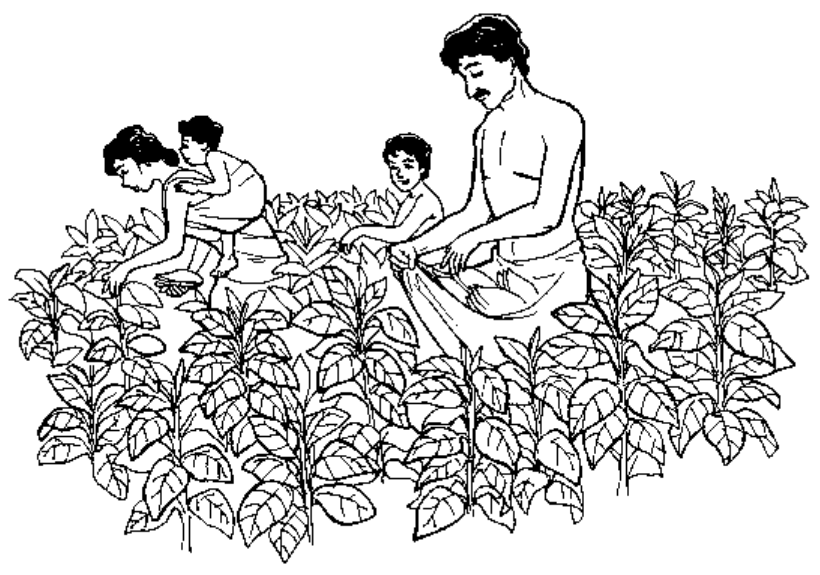
considerable proportion of their annual household income.

Do you have any idea how many steps are involved in just preparing the leaves to be rolled? First comes leaf collection. Collectors leave home at dawn during the hot summer months of harvesting and may walk long distances to reach the collection sites. Women do much of the collecting and processing. When they return home with their harvest of leaves, infected, immature, torn and small leaves are weeded out and the remaining ones are graded and tied into bundles of 50 . These are delivered later that day to a co-operative purchase centre, locally known as 'phad'.

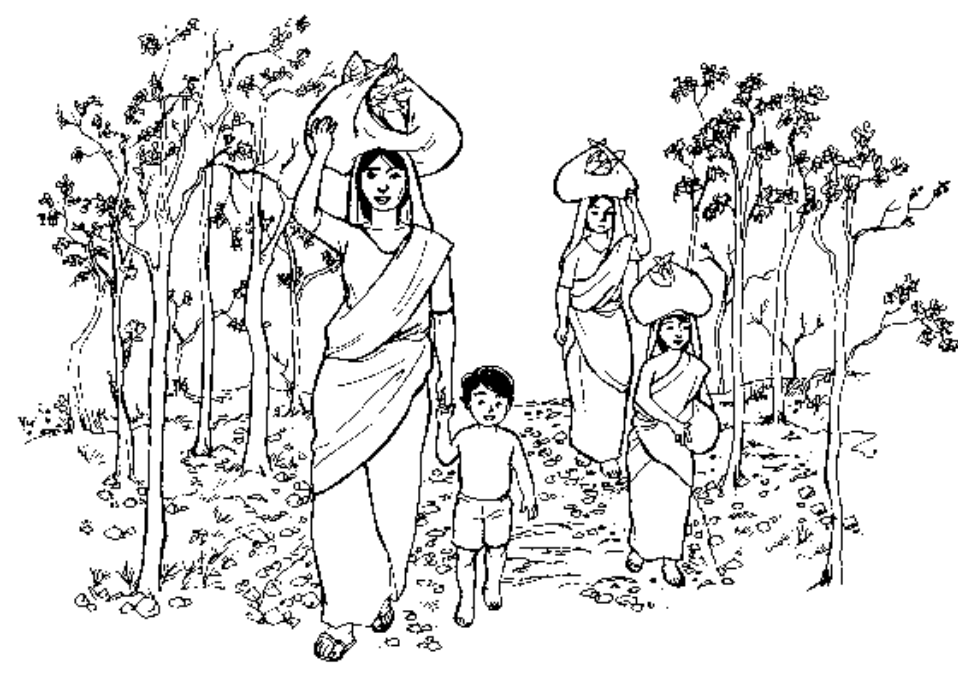

At the co-operative, the leaves are spread out in fields to air dry for about a week. Care with packing is extremely important at this stage as the leaves are easily damaged. To avoid cracking, they are watered and left to soften for some hours before being placed into jute bags. These are left to dry in the open for around two days and are then transported to storage centres.

Traders buy and distribute the tendu leaves, along with cotton thread and blended tobacco (mostly from Andhara Pradesh), to rural villagers for hand rolling. Operating all year round in the villagers' homes, this cottage industry involves the whole family, especially women. The beedis, which are round at the burning end and flat at the smoking end, are tied with cotton thread, the colour of which identifies the manufacturer. 
Manufacturers' agents collect the beedis and roast them over a charcoal fire, in specially designed factory chambers. This removes moisture and imparts a distinctive flavour. The tiny cigarettes are then tied into bundles of 25 and wrapped in labeled paper. The key to beedi making lies in the blending of the tobacco, which is treated as a trade secret.

\section{Trends}

Beedis are synonymous with India and their production benefits many rural families. They range in price from US\$ 0.05 - 0.12 a packet. The production of beedis brings together collectors, traders and processors, living in different regions and profiting in different ways. The tendu leaf trade is an excellent example of benefits that can arise from co-operation amongst harvesters. The co-operatives receive $100 \%$ of the net profit from the trade of leaves and by law, re-distribute this $50 \%$ as deferred wages to collectors, 30\% for village infrastructure and $20 \%$ for the sustainable development of forests where tendu grows. However, the benefits for villagers who roll the beedis are quite different, as the manufacturers

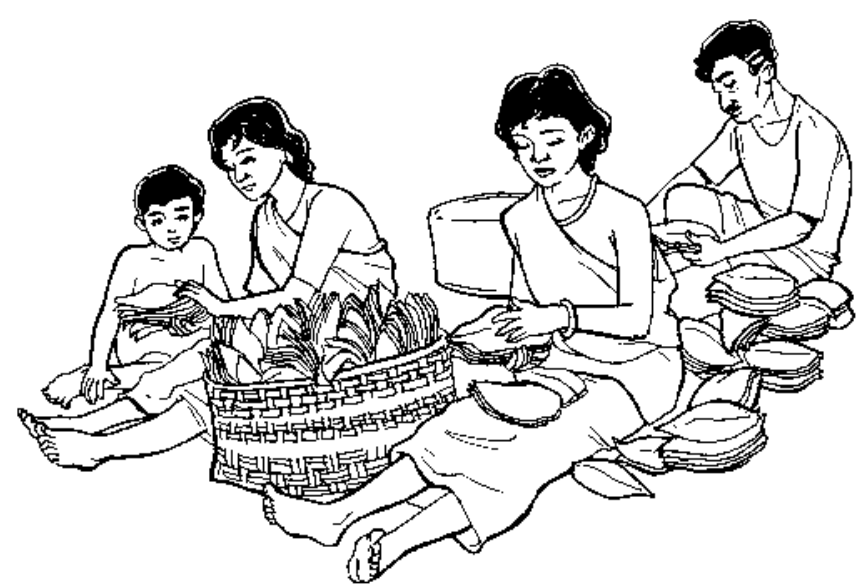

Collectors sort the harvested leaves at home with their families. pay them very low wages.

Due to the large scale income generating potential of tendu leaves, the Government has initiated several actions to promote the active participation of rural villagers, not only in collection but also in processing and storage. But there is a growing concern about the quality of the leaves as, since nationalisation, co-operatives have tended not to ensure quality during harvesting, processing or packing.

Over the past few years, demand for tendu leaves has stagnated as beedis have gradually been replaced with lower quality cigarettes and Gutkas (a chewable mixture of betul nut and tobacco). Nevertheless, the trade of tendu leaves, estimated in 2002 to be at a production level of around 10 million standard bags per year, and worth approximately US\$ 250 million, remains very important for India. 


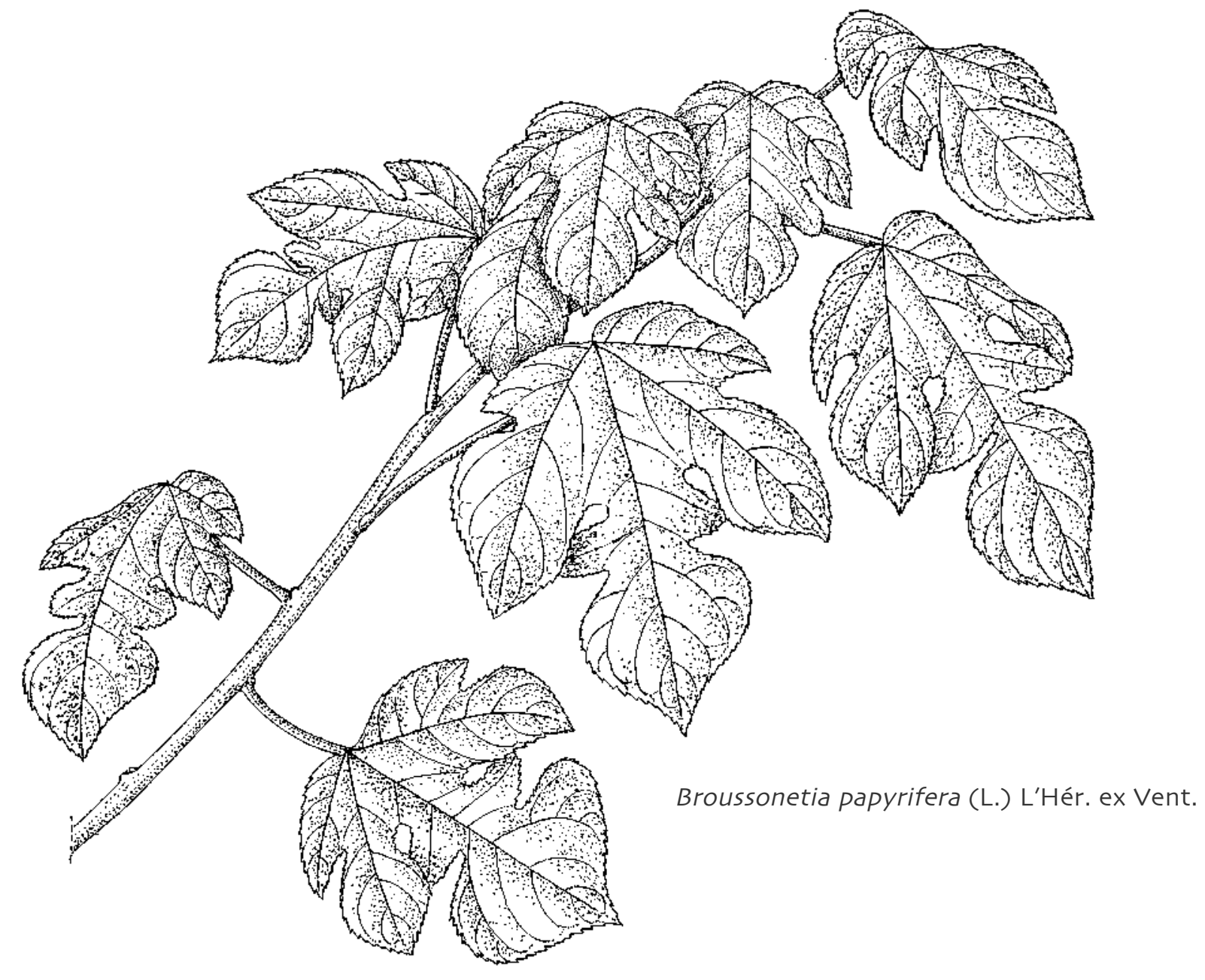

\section{Mulberry tree, bark for paper}

Lao case by Catherine Aubertin 


\section{Mulberry trees: Paper-making bark}

The bark from the 'paper mulberry' tree has a long history of use in Laos and a reputation as a good raw material for paper-making. Local villagers have used it to create cardboard decorations, shape triumphal arches and make a range of religious objects as well. Prior to the introduction of imported sisal or nylon ropes, farmers would also make string and ropes from the strong mulberry fibres. Nowadays, paper mulberry is a good example of the successful domestication* of a forest product. It is especially common in northern Laos,

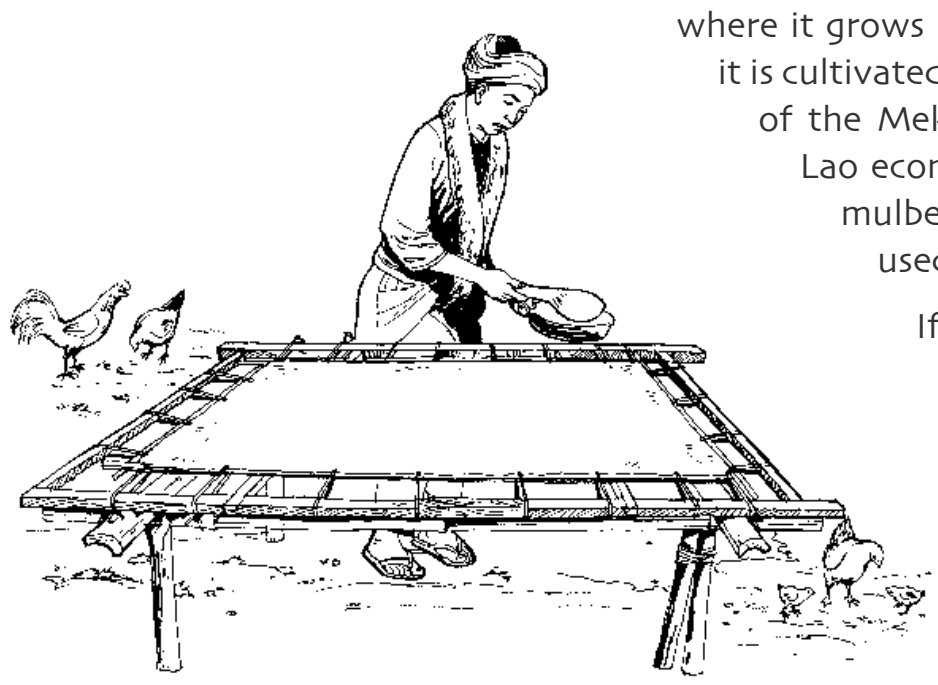

Yao people, from Vangvieng in Laos, still make paper by hand, for writing upon and for use in religious rituals. it grows naturally and also, in northwest Laos, where mulberry bark, especially in Thailand, where it is used for making high quality paper products.

If you ever receive a letter written on mulberry paper, hold it up to the light to reveal its transparency and distinctive, fine texture. This lovely writing paper may well have been produced in Thailand, South Korea or Japan, where mulberry bark is used to produce luxury stationary, banknotes, objects for religious worship and lanterns. However, it is highly likely that the raw material originated in Laos.

\section{Harvesting the bark}

Paper mulberry is a small, shrubby tree that grows rapidly, reaching its full height of around $3 \mathrm{~m}$ after only 6-12 months. It has very large leaves, a stem diameter of around $5 \mathrm{~cm}$, smooth grey bark and small red fruits, which are edible. Paper mulberry, which is known as 'posa' in Lao and 'salae' in Khamu, often spontaneously sprouts" after the slash and burn* of rice fields. Growing freely throughout the country, the Lao Ministry of Agriculture has labeled it a weed in spite of its significant value. In addition to its wild growth, farmers often plant root cuttings and some growers, especially those with larger plots of land, find it profitable to cultivate as a cash crop or to intersperse with other crops. 
Frequently found in plots where rice was cultivated 2-3 years earlier, paper mulberry serves a weed control function (while also providing a source of income) until the fields can be replanted. The branches of both natural and cultivated stocks are harvested when the trees are around 12 months old and then repeatedly, every 6-9 months (generally at the beginning and end of the dry season). However, if the trees are used in land speculation or to mark ownership, farmers may wait several years before harvesting. Collecting the bark destroys neither the plant, nor its environment - usually only 3-5 branches are harvested from each tree, allowing for rapid recuperation through the sprouting of new shoots. Bark from the trunk is also used when whole plants need to be removed, for example to clear land.

\section{Paper-making}

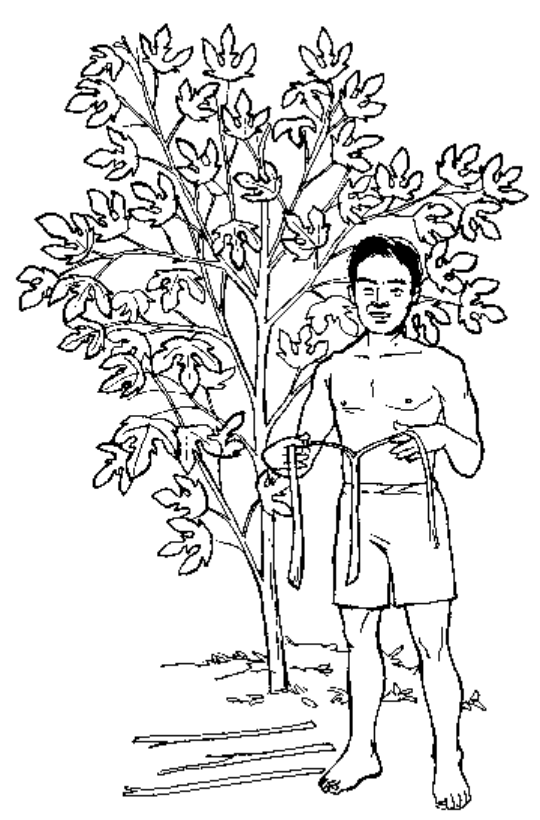

Farmers harvest the mulberry bark by stripping it from the cut branches.

The best quality mulberry paper is produced from the bark of branches that are 6-12 months old, with the highest grade bark (and paper) appearing as white as possible, without knots or fungal discoloration. Generally, the younger branches offer the best quality but older bark is also tradable. The bulk of the harvest is sold for processing in other countries, with a small amount being retained for paper manufacturing in Laos.

Both men and women are involved in planting and harvesting the bark. After stripping bark from the cut branches, the outer surface is discarded and the inner bark is hung out in the sun for a day to reduce the chances of mould contamination. The dry bark is then sold directly to a village trader, folded in two, into $1 \mathrm{~kg}$ bundles.

The first step in making paper involves washing the bark and separating out the fibres by hand, before grading and soaking them overnight. Caustic soda or ashes are then added and the resulting mixture is stirred and boiled for 6-8 hours to facilitate bleaching and thickening. The resulting fibre slurry is cooled in water for a day, with any lumps being cut and ground.

The damp pulp is poured into fine sieves of wire mesh within a simple frame. These are dried in the sun for a few hours, before the paper is separated from the

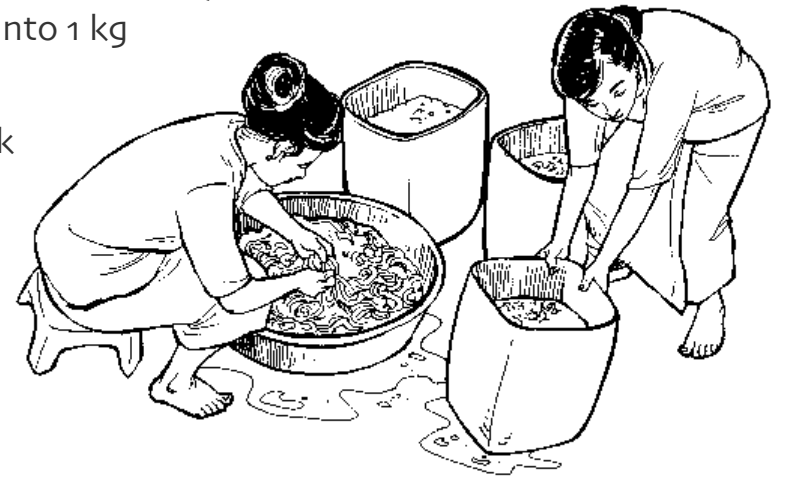

Women wash the bark fibres as the first step in the paper-making process. 


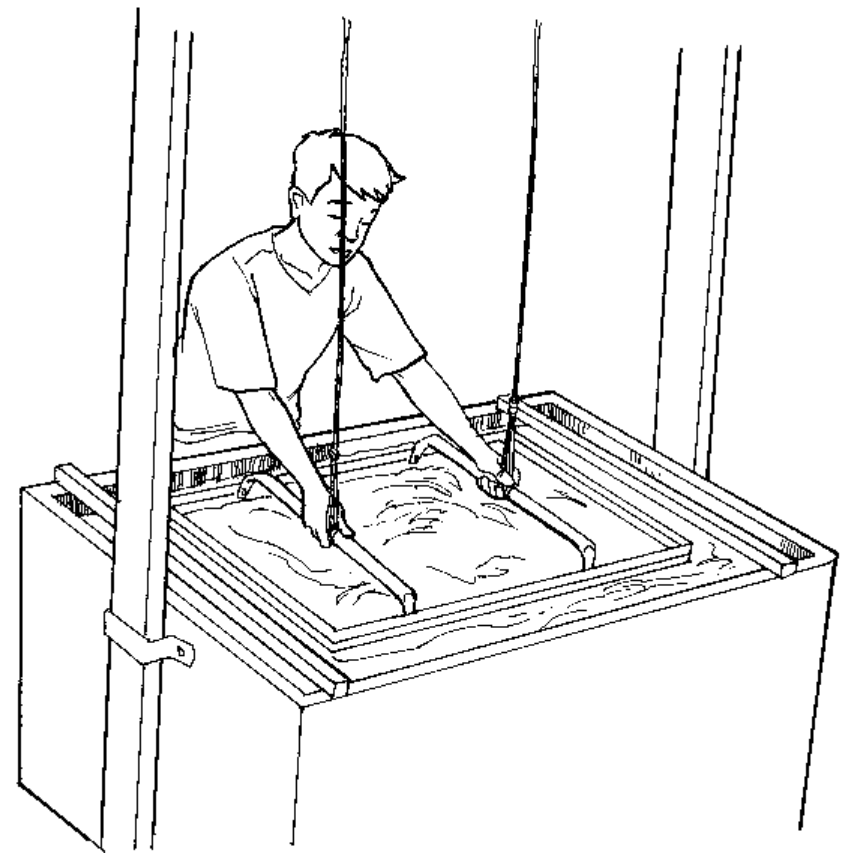

Fine sieves are used in the manufacture of mulberry bark paper. netting and pressed. The standard paper size is $60 \times 80 \mathrm{~cm}$, although various frames are used to create different sizes, with a group of seven people producing about 100 sheets per day.

\section{Trading the raw material}

Since the economic opening of Laos in 1989, farmers have profited from a growing export market for paper mulberry. It has a higher economic yield per hectare than rice but a lower return than for maize or kidney beans. In some provinces, families harvest an average $100 \mathrm{~kg}$ of bark per year. In 2000, this provided an annual income contribution of around US\$ 35, at US\$ 0.35 per $\mathrm{kg}$. In 1999, the total export figure, mainly destined for Thailand, was estimated to be around 500 tonnes (although this is believed to be an underestimation).

To ensure a good supply, Thai merchants often give Lao farmers cash up front for their bark harvest. Sourcing Lao bark (and semi-processed pulp) is an appealing option for Thailand's paper industry due to the lower land, labour and production costs in Laos. However, as most of the profit comes in the final processing stages, a shift from being a low value raw material supplier to value adding within Laos would increase returns for Lao people involved in the paper mulberry trade. Such a shift would however, require investment in a processing industry and appropriate training for Lao workers. 


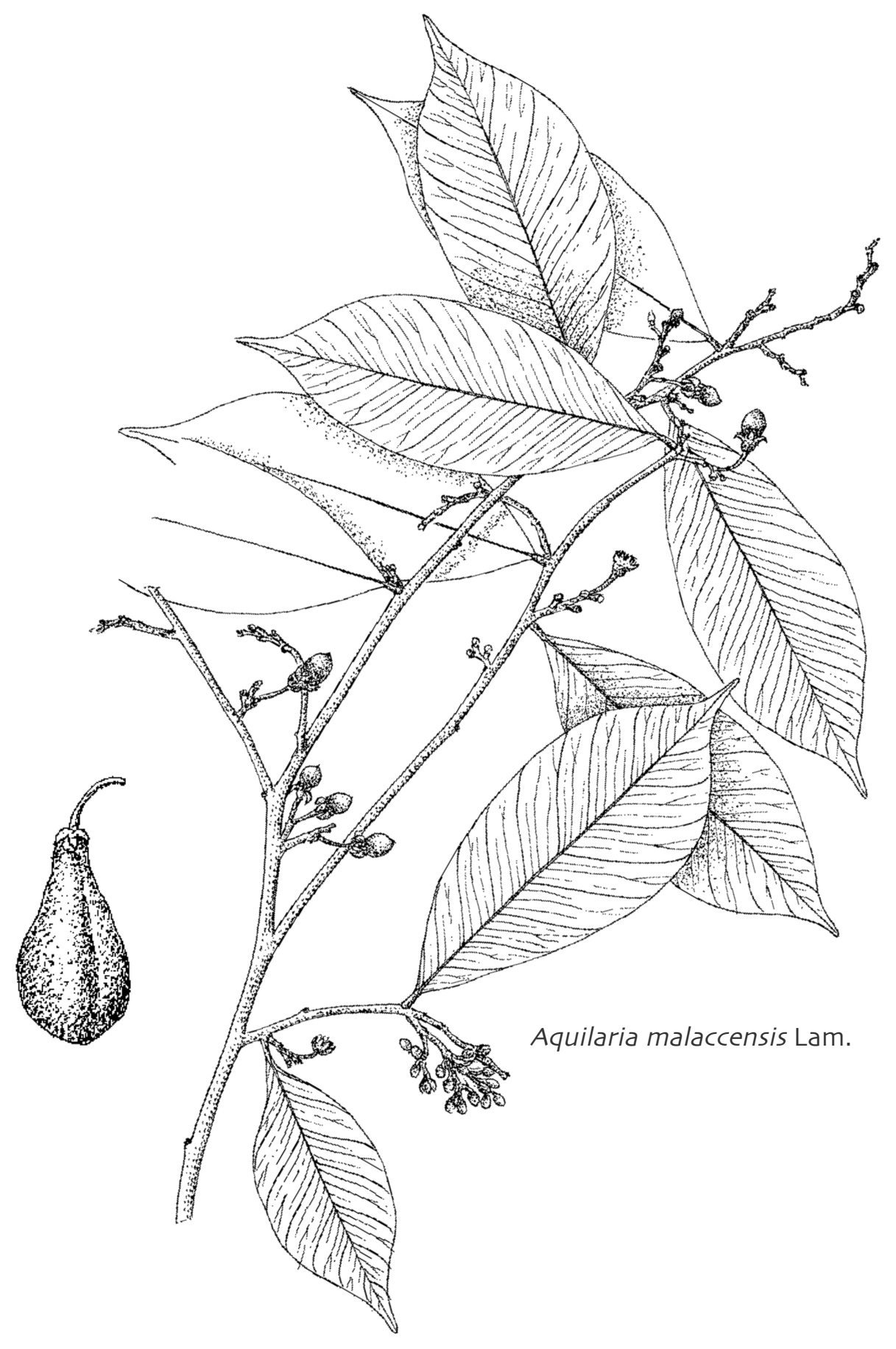

\section{Agarwood, fragrant wood}

Indonesian case by Marina Goloubinoff, Jenne de Beer and Esther Katz 


\section{Indonesian agarwood: Gamble in the forest}

Hata-san is the president of one of the most prestigious incense companies in Japan. When Kyoto was still the country's capital, his forefathers would delight the imperial court with sublime fragrances. Today, next to the workshop lie treasures from times past - unique pieces of 'agarwood'. These silent witnesses to forever vanished forests are not for sale. They are only used on rare occasions when connoisseurs gather for incense ceremonies.

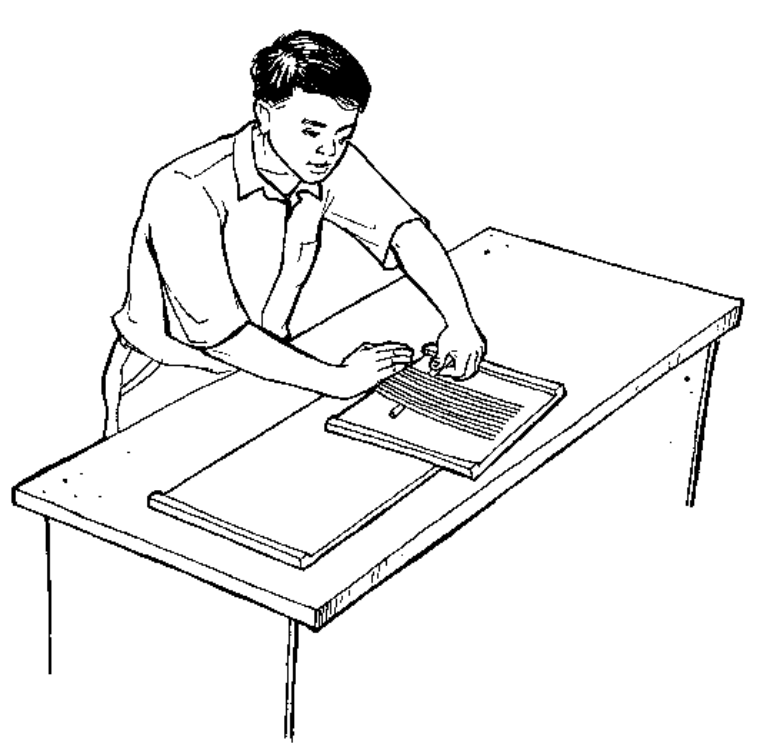

Prestigious incense companies still require the skills of good artisans (Kyoto).

\section{What is agarwood?}

Agarwood is a marvellous but pathological phenomenon. Traded as agarwood, it is commonly referred to as gaharu in Indonesia but is also known as eaglewood, aloes wood and agalocha. It forms as a reaction to fungal and/or bacterial attack and is found on certain species of Aquilaria a fast growing, evergreen* tree, that normally grows to $18-21 \mathrm{~m}$ but sometimes up to $40 \mathrm{~m}$ in height. Infected trees secrete a fragrant, protective oil into wounded areas (roots, branches or sections of the trunk), which gradually become harder and darker. Formerly, harvesters would cut only the infected parts in the hope that the tree would produce more of this resinous wood. However, because of market pressures, harvesters are now taking even poor quality agarwood, threatening the survival and sustainability* of these trees.

Aquilaria species that produce agarwood are found throughout Asia. For example, A. malaccensis, which is traded the most, can be found from India to Indonesia. These trees are relatively easy to grow and experimental plantations exist in most producing countries. However, fungal introduction (or inoculation) still poses a major problem, making it difficult to produce agarwood on a significant scale. This is why it is still harvested from the wild. 
Agarwood has been used to make high quality incense since antiquity. The Chinese describe its smell as "a sweet, deep but balanced fragrance" and continue to use it in religious and festive celebrations, as do Arabian, Indian and Japanese people. Agarwood is also part of many traditional pharmacopoeias, dating back to medieval times and Chinese doctors still prescribe it for colds and digestion problems. Oil extracted from agarwood is used in Arabic countries as a perfume as well. Unlike many industrial perfumes, it is suitable for hot climates as the longer you wear it, the better it smells! In spite of its unique qualities though, agarwood is rarely used in European perfumeries because of its cost, and good quality synthetic substitutes are yet to be created.

\section{The moving frontiers of agarwood}

The Indian sub-continent was the main source of agarwood for many centuries but as trees became scarce in the middle of the twentieth century, extraction intensified in Indochina. However, conflicts in that region during the 1960 s and 705 hindered collection. War destroyed part of the forests but paradoxically, since many trees were damaged by bombs, they started to produce agarwood. In some countries army factions and guerrillas took control of this lucrative business. Activities shifted to Malaysia and Indonesia, where agarwood had long been extracted but never intensively. Around this time, demand for agarwood in the oil rich Arabic nations started to increase.

Systematic prospecting and extraction commenced in Sumatra, Indonesia and then, in the mid-1980's, traders focussed on Borneo, even hiring helicopters to drop harvesters into remote rainforests. These agarwood supplies lasted about 10 years, until new sources were discovered in Irian Jaya. The latest 'El dorado' is Papua New Guinea - but for how long? Kalimantan and Sumatra still produce agarwood but it's harder to get nowadays and the general quality has declined.

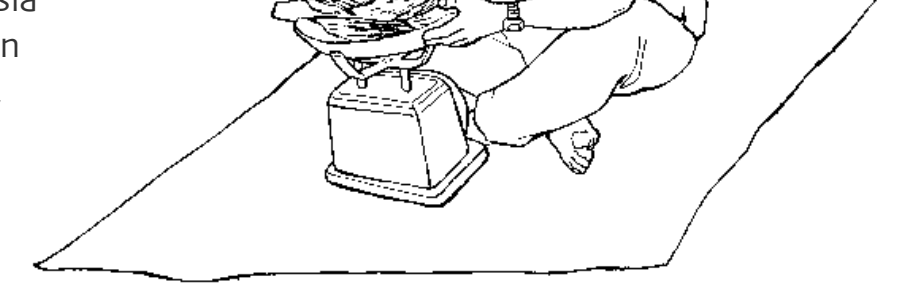

In the past, when the Punan of Kalimantan found an Aquilaria tree, they would mark it, check for agarwood and cut only the most fragrant, darkest parts. This traditional management would generally allow the tree to persist in the forest and continue growing. 


\section{Trade and markets}

In Indonesia, the agarwood trade involves many stakeholders, especially at the local level. You often find local middlemen exerting control over harvesters who are in debt to them and also exercising some bargaining power over bigger traders who need regular supplies. The agarwood passes through successive siftings and grading can be quite complicated, with intuitive judgement being more important than simple criteria (like origin, colour and density).

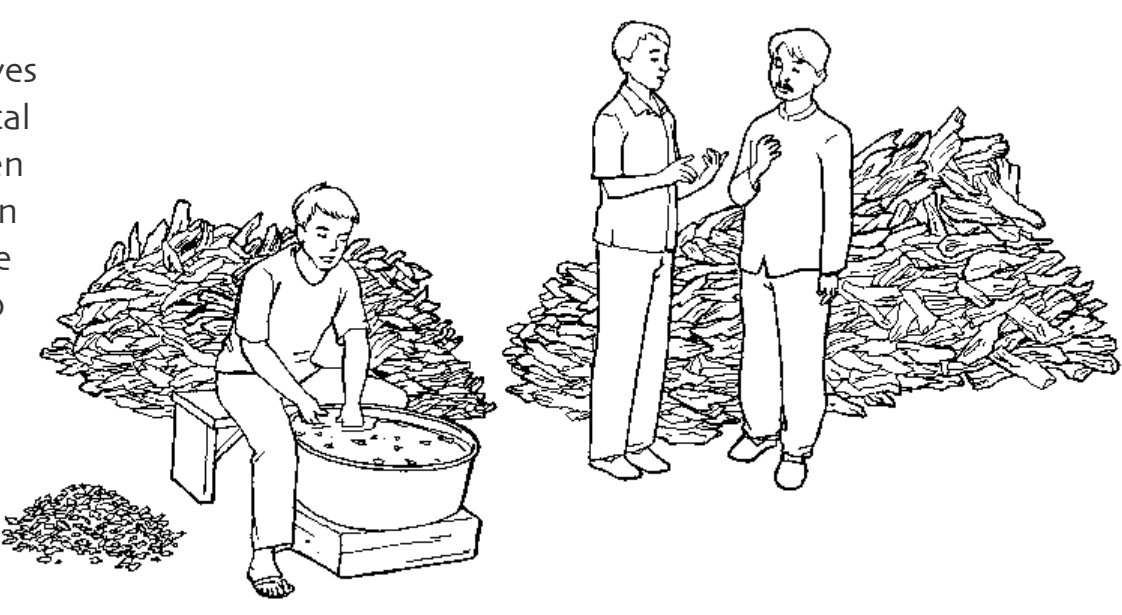

Buyers choose agarwood according to its end use and consumer tastes. Arabian people like high and medium grade agarwood from Malaysia or Kalimantan, while the Taiwanese prefer Sumatran agarwood for medicines and Irian chips for incense. Prices vary, depending on the origin and the relationship between demand and availability. High grade agarwood from Kalimantan for example, can fetch US\$ 400 per kg at a regional trader level. On reaching Singapore, the best pieces can cost US\$1,000 per $\mathrm{kg}$, while in Saudi Arabia, customers may pay around US\$3,000 per kg.

Acting upon CITES* (the Convention on International Trade in Endangered Species of Wild Fauna and Flora) recommendations, the Indonesian government established an export quota on $A$. malaccensis. However, it is currently unclear whether this measure is reaching its conservation goals.

\section{Dreaming of gaharu in Kalimantan}

Pak Ipo Dole had a dream - a pretty girl was smiling at him in the forest. His grandfather says it's a good omen for gaharu hunting. He hopes so! Last time, he and his cousins spent a week in the forest, finding only $4 \mathrm{~kg}$ of low grade agarwood. After paying their debt to the trader and buying clothes, almost nothing was left. Fifteen years ago, Pak Ipu Dole's uncles would stay three days in the forest and emerge with a bunch of fine black gaharu. He starts to daydream about finding good gaharu and going downstream to sell it for a better price. Imagine finding ten or more kilos! He'd love to get a long tail engine for his canoe, put a zinc roof on his house and be respected by his in-laws. His grandfather looks at him: "You'll find gaharu but be careful and don't go too far unprotected. You cannot be sure that all the guys you meet in the forest are friendly ..." 


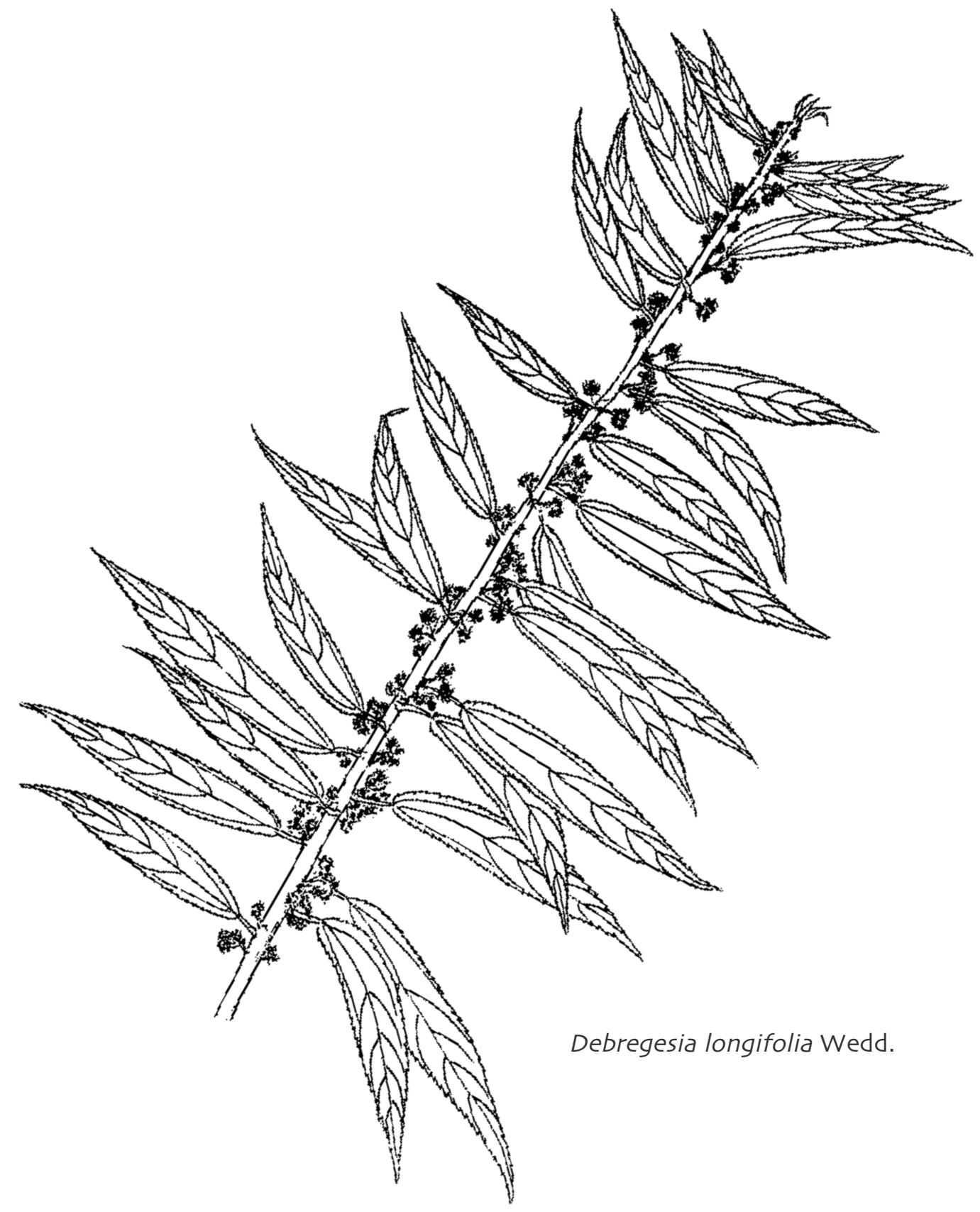

Tout tiang, bark glue for incense Lao case by Joost Foppes 


\section{Incense sticks: The bark that binds the scent}

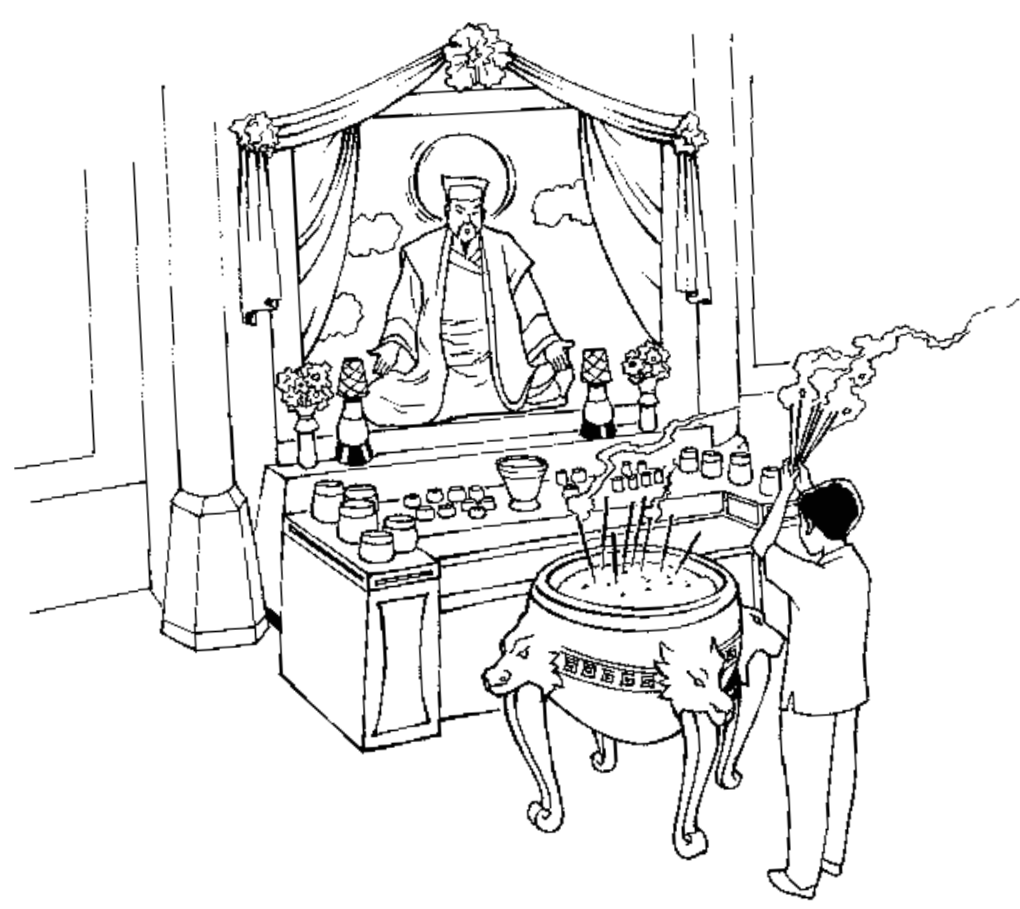

Every day, millions of people in Asia light incense sticks in their homes, temples and gardens, honouring their ancestors and local spirits or simply wishing for good luck and prosperity. Between December and April, the people of Ban Tat Mouan and many other villages in northern Laos, wander into the forests every day to collect the bark of a local shrub they call 'tout tiang'. They dry it in the sun and sell it to passing traders. The villagers know it goes to China and have heard it is used to make incense but are not quite sure how.

Have you ever wondered how incense is made? Fragrant substances are combined with sawdust and this mixture is then applied to tiny sticks with a special glue. Tout tiang produces just the right type of glue and as a result, has become very popular in the incense producing Yunnan Province of China. This story is all about a little known forest product which has found a foreign use and market. However, rising demand has led to its rapid depletion - presenting local people with the challenge of addressing declining supplies, while meeting demand and sustaining their families.

\section{Local harvesters}

Several thousand village communities collect tout tiang in the mountains of northern Laos, including the Ban Tat Mouan community. Here, situated in the Oudomxay Province, approximately 250 villagers live in upland and lowland areas, cultivating rice, raising buffalo, cattle and pigs and collecting a wide variety of forest products. The 38 local families use a forest area of around 3,800 hectares of hilly terrain in this sparsely populated region. 
Most of the families cannot produce enough rice to feed themselves all year round in this narrow river valley but the consumption and sale of numerous forest products compensates for this shortfall. The villagers estimate that they actually spend more time gathering forest products than farming and raising livestock. Hundreds of forest products are used daily and these goods also account for around $80 \%$ of the villagers' cash income. Among the nine main products sold, the most important is local cardamom (Amomum spp.), which supplies $50 \%$ of the average family income. Second is broom grass (Thysanolaema maxima) adding $7 \%$, while incense bark ranks third, contributing approximately $6 \%$. The first two products have been harvested for a long time without any visible effects on their availability. However, the same cannot be said of tout tiang.

\section{From collection to trade}

The name tout tiang is derived from the local Khamu language. It is also known as 'peuak meuak' in Lao and 'shui-mao-pi' in Chinese. The bark is harvested from a local plant belonging to the Urticaceae family (probably Boehmeria malabarica but possibly Debregesia longifolia - international botanists are yet to confirm the species). This small shrub likes a wet environment and occurs naturally around forest streams and in narrow bands along rivers. Locally, the plant is rarely used. However, the export trade for its bark has grown over the past seven years, coinciding with the opening of the Lao economy to the outside world. Tout tiang is sold to buyers from neighbouring China and in the year 2000 the total quantity exported was an estimated 685 tonnes of dry bark.

Commercial harvesting commenced around 1997 and since then, natural stands of tout tiang have been rapidly exhausted. According

The bark of tout tiang is harvested from the wild, dried in the sun and then sold in little bundles. No further processing takes place in Laos but in China, the bark is crushed and boiled to produce the incense making glue.

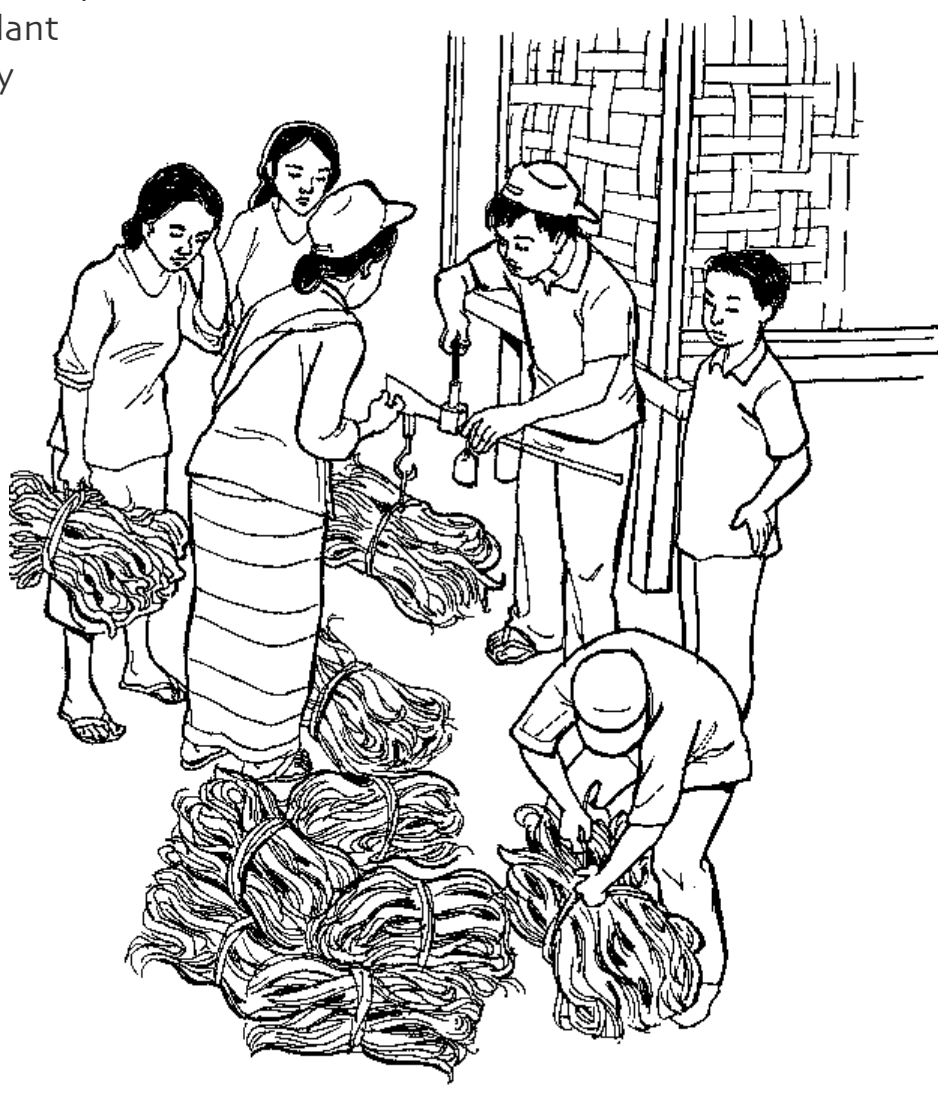


to the Tat Mouan villagers' own estimates, their production of dried bark fell from over five tonnes in 1997, to only half a tonne in the year 2000. Commercial harvesting has had a rapid and negative impact on natural stocks, calling for some innovative responses from local gatherers.

Together with researchers, the community experimented with ways to produce growing stock to replace the lost vegetation. They discovered the plant is easily propagated* from stem cuttings, taking about three years to grow to a harvestable size. A nursery was established and 5 hectares were planted as a first effort in 2001, with further plans to add 2-3 hectares each year. Neighbouring villages are also showing interest in following this example. When harvesting, if some above ground stems are left intact and plants are not uprooted, regeneration can occur, with new coppices* emerging from the underground roots of the parent clump (i.e. the originating cluster of plants).

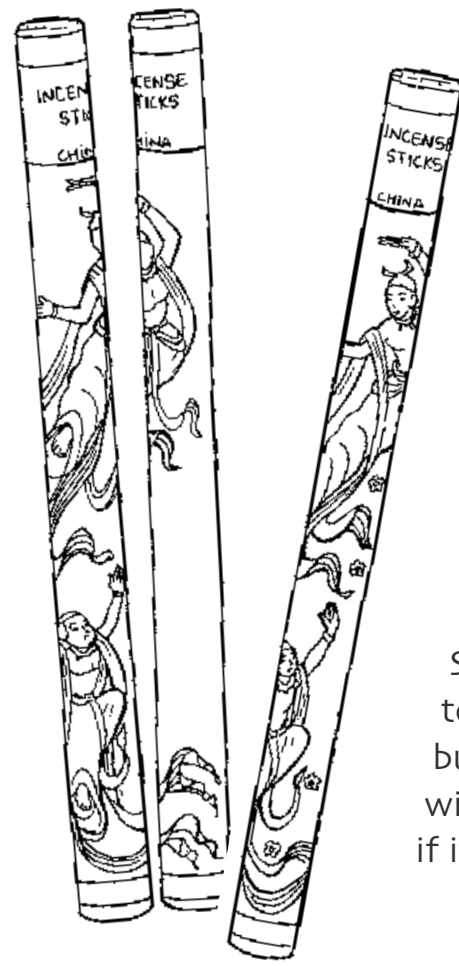

\section{The marketing chain}

Local Lao traders buy the bark from the forest collectors and in turn, sell the product to Chinese traders. Prices in the year 2000 varied from US\$ 0.28 per $\mathrm{kg}$ at the farm gate to US\$ 0.33 per $\mathrm{kg}$ at the Chinese border. This limited increase covers transport and taxation costs, leaving a profit of $7-8 \%$ for the Lao traders.

While the raw material is produced in Laos, all the processing and the sale of (and main profit from) the final product occurs in China. The Chinese border acts as a barrier leaving Lao traders in the dark about markets and processing - and thereby preventing them from getting better prices or adding value themselves. Families that harvest the bark might benefit from learning basic Chinese language and marketing skills.

So, what could improve equitable trade for both countries? Lao traders need to know how much an incense stick costs and how they are produced. Chinese buyers need to know that the scented sawdust on the incense sticks is glued with bark from a forest plant in Laos and that tout tiang could become scarce if it is not well managed and justly valued. 


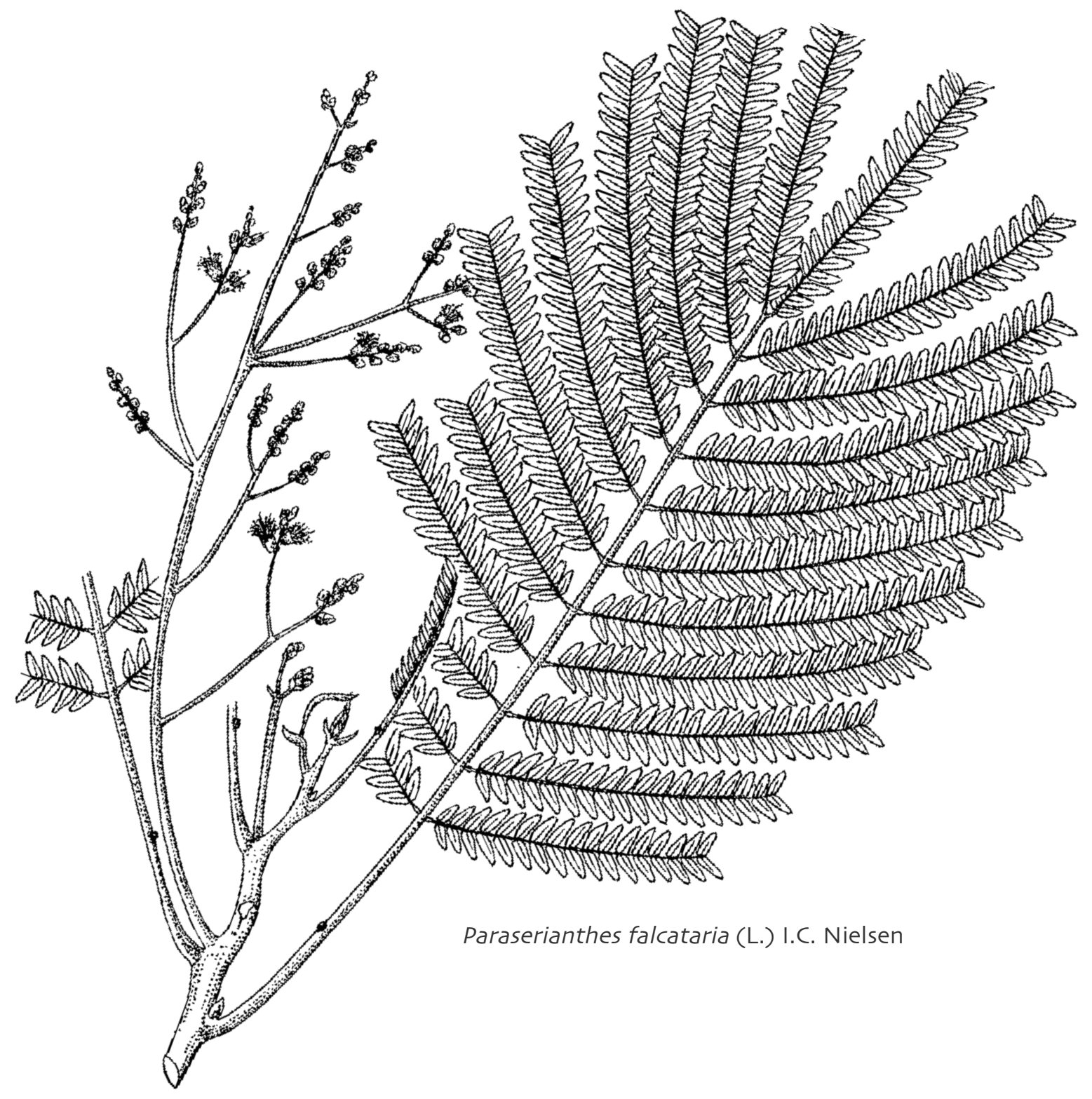

\section{Woodcarving}

Indonesian case by Pipin Permadi and Dede Rohadi 


\section{Woodcarving: More than just beaches in Bali}

Bali and woodcarving are intertwined - as you soon discover when visiting this small Indonesian island, east of Java. Carvers and the fruits of their labour can be found throughout this popular holiday isle, with artworks ranging from ornate gateways and village statues to traditional and popular carvings created for sale. Gianyar is the main centre of the Balinese woodcarving industry, with roughly $90 \%$ of producers located within this district.

\section{The growth of tourism and commercial woodcarving}

The Balinese have practiced woodcarving since at least the ninth century. The transformation of a community activity into a commercial enterprise began around 1935 and the industry has since continued to grow, along with the booming
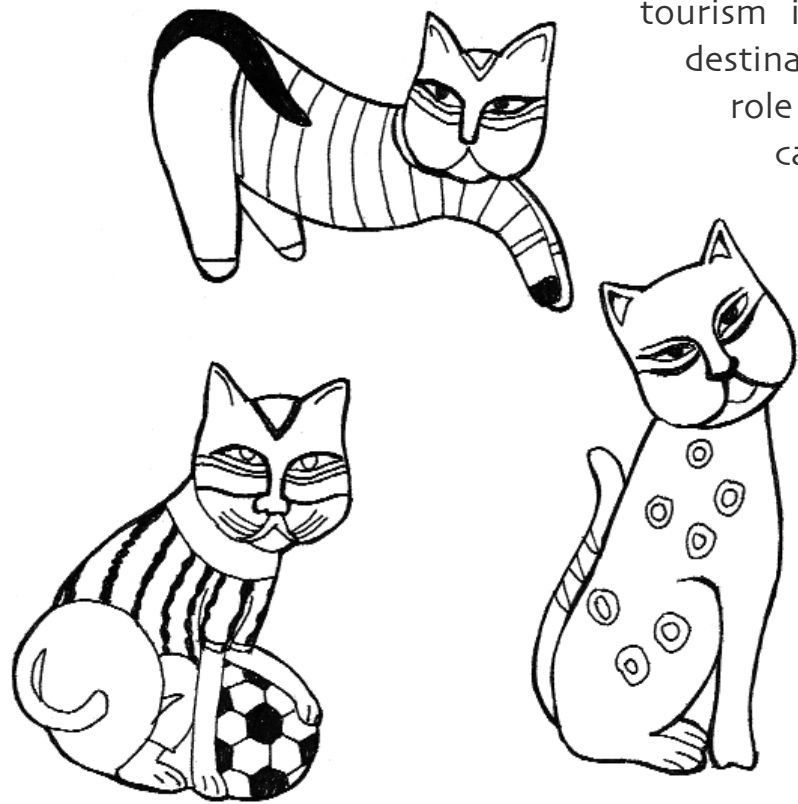

Have you ever come across small, colourful woodcarvings like these in Asian shops, handicraft stores or the popular markets of the world? Chances are they were created by the hands of Balinese carvers. tourism industry (which has seen Bali become the most poplar destination in Indonesia). In Bali, woodcarving plays an important role in both everyday life and the regional economy, with many carvers, tree growers and merchants deriving a considerable portion of their overall income from the supply of raw material and the production and trade of carvings. These handicrafts have proved popular locally and amongst tourists and have even triggered a successful export industry, which in 1998, was worth US\$ 99.5 million.

Initially, commercial carvings focused on images of mystical objects like Gods and Goddesses, drawing on traditional woodcarving practices. As more foreign visitors came to the island, the demand for carvings increased. In the mid-1970s, a woodcarving school and cooperatives were established and, influenced by western artists, a new trend developed in the industry - that of mass production. Locally known as 'pop art carving', these designs were much simpler in form than the earlier carvings and included less detail. High volumes were 


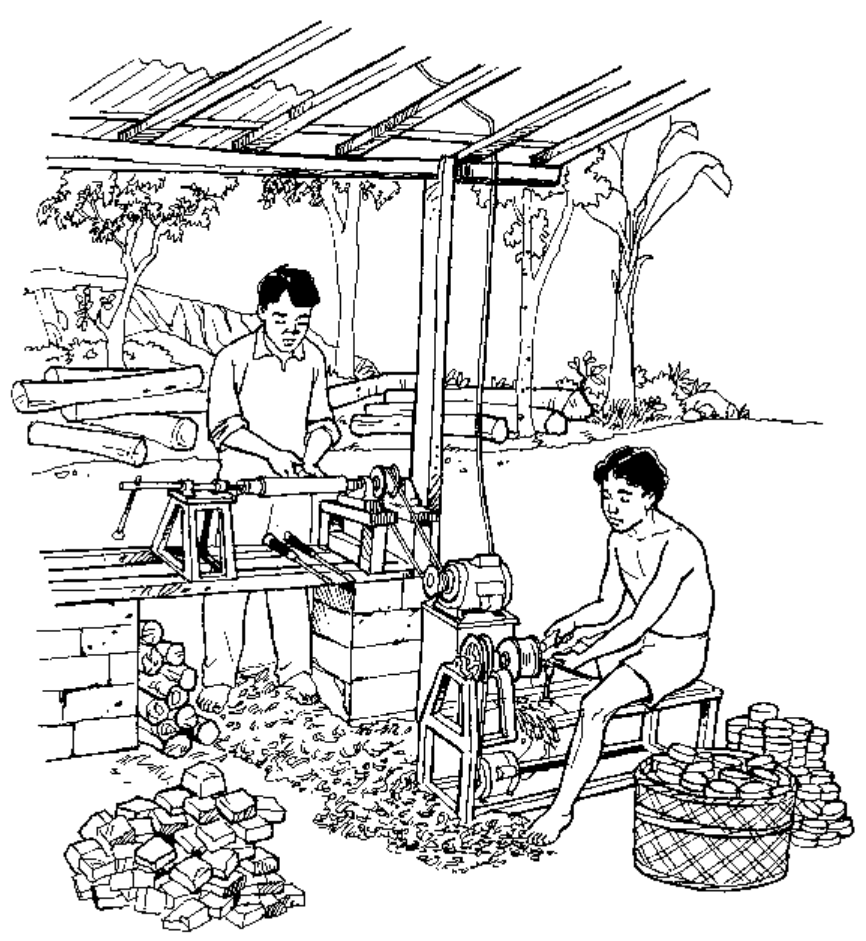

Machines are usually only used to give form to certain pieces of mass produced artwork. produced, with a high turnover of sales, particularly for objects like frogs, tigers and elephants, and for models of fruits like bananas and watermelons.

Over time, hundreds of diverse designs have appeared. Being fairly quick and easy to produce, pop art offers a quick economic return and has created work for a large number of minimally skilled carvers. For 1999, official figures indicate there were more than 23,000 Balinese woodcarvers (working in households, workshops and factories), with a combined wood consumption of $60,000 \mathrm{~m}^{3}$.

The amount of money that carvers earn varies, ranging from around US\$ 2 per day for work on semi-finished pop art, to around US\$ 7.50 per day for more skilled woodworking. Many women and children are also involved, usually with the final stages like sanding and painting. Their average income is around US\$ 0.80-1.00 per day for work

generally done at home during their leisure time. At the other end of the scale, a well known artist, taking about 6 months to complete a large, ornate statue, might charge as much as US\$ 9,000. In addition to the pop art, there has always been a market for fine quality Balinese woodcarvings, borne of imagination, creativity and traditional craftmanship.

\section{The raw material}

In the past, only a few species were used for carving, including 'sawo kecik' (Manilkara kauki) and 'nangka' or jackfruit (Artocarpus heterophylla). Wood from these trees has long been used for traditional and religious woodcarvings and even today, remains the preference when making ornaments for 'pura' (small private temples). With the rapid growth of the woodcarving industry, Bali's limited forest resources have been unable to meet the demand for raw material. Carvers have experimented with different types of wood, looking for alternatives to the preferred but less available species. Most of their wood is currently brought in from elsewhere, mainly from Java, with sandalwood and ebony being shipped in from places like the Timor islands and Sulawesi. Bali itself supplies only around $21 \%$ of the raw material, which is drawn largely from farms and private plantations - often growing 'belalu' (Paraserianthes falcataria), also known locally as 'sengon'. 


\section{Belalu - a new role in woodcarving}

Belalu provides the most widely used wood for mass production carving. This tree was first introduced into Bali through the Ministry of Forestry's land rehabilitation programme in the early 1980 s. The government had originally distributed $P$. falcataria seedlings to local people to plant in their home gardens, to improve soil fertility on marginal lands and provide fodder and fuelwood. By good fortune, wood from this fast growing tree was later found to be suitable for pop art carving as well. Its relatively cheap price compared to the slower growing species and its advantageous properties (being light and easy to work with and paint) quickly made it popular amongst the woodcarvers.

Threatened with over-exploitation, some of the slow growth native* species are becoming scarce due to the high demand for their wood, particularly for the better quality woodcarvings. Some research is currently underway into establishing trial plantations to develop these specialist sources of timber. For tree growers however, the quick growing species like belalu and the acacias (e.g. Acacia mangium) pose a more attractive investment option, with the woodcarving industry ready to pay good prices for logs. With a trunk diameter of $30-40 \mathrm{~cm}$, belalu nets the owner US\$ 40-50 per $\mathrm{m}^{3}$, depending on the distance

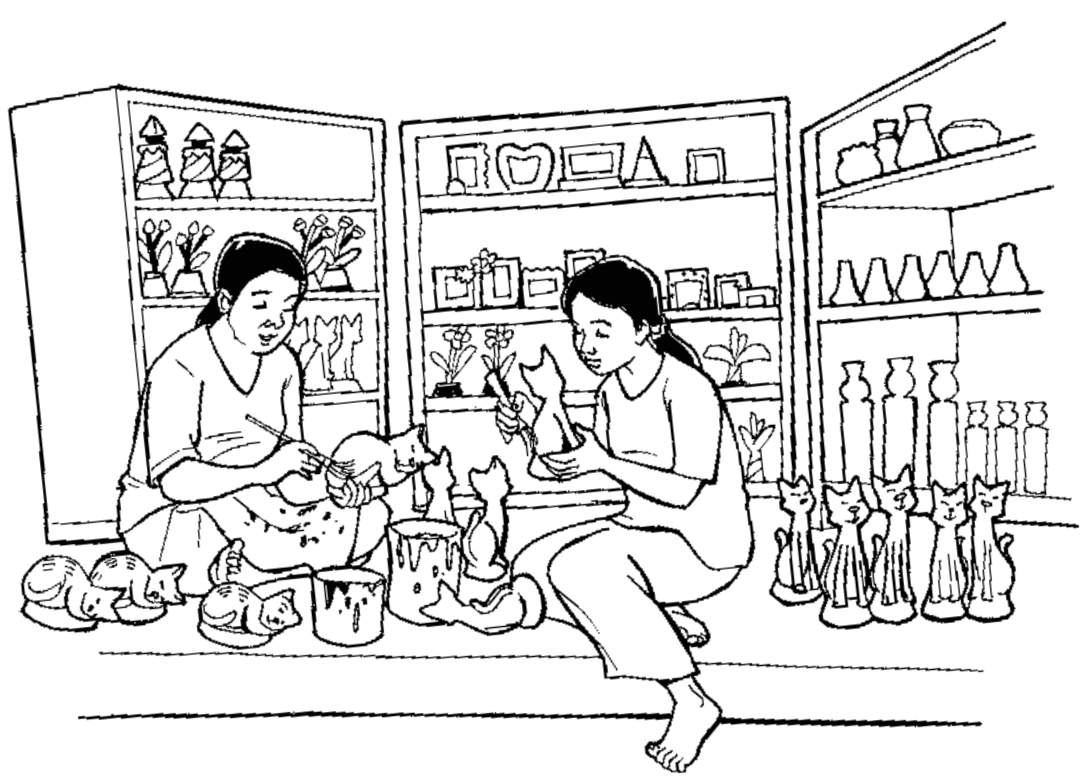

from the farm to the nearest accessible road (which in turn, determines the transport costs). These prices have provided an incentive for both small scale farmers and larger scale tree growers to increase their plantings around Gianyar and the surrounding districts. This arrangement is mutually beneficial for tree growers and the woodcarvers, who gain access to an increasing supply of suitable, good quality wood on their home island of Bali.

Most of the colourful cats found in handicraft stores worldwide are sanded and painted by women and children. 


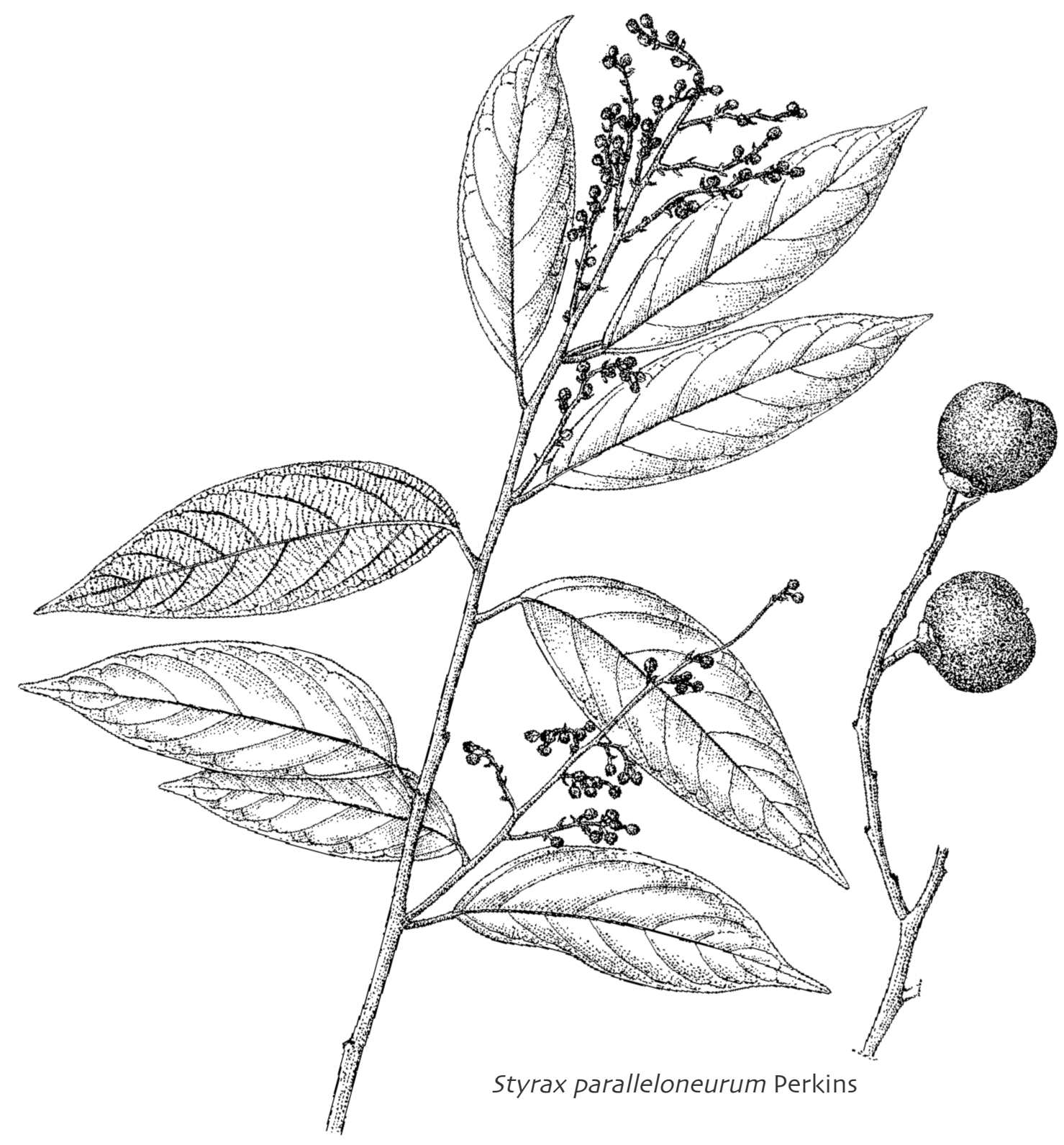

\section{Benzoin resin}

Indonesian case by Carmen García Fernández 


\section{Benzoin resin: Scent from the far east}

Benzoin is an ancient resin, which Middle Eastern traders once described as the 'frankincense of Sumatra'. For more than a thousand years it has been sold in markets around the world and as early as the ninth century it was being traded in China and used in traditional medicines and incense production. Arab traders introduced this fragrant resin into Europe, where it became a valuable commodity from the Far East, used by royal families and aristocrats. Nowadays, its distinctive scent is still enjoyed as benzoin incense is burned during celebrations and religious rituals.

So, where does this ancient resin come from? Most benzoin is harvested from Styrax paralleloneurum trees or 'haminjon toba' in Indonesia. Initially they grew wild but for more than 200 years, Batak farmers have cultivated them in forest gardens, in the stunning highlands of North Sumatra. For many decades, money from the benzoin trade has been invested in educating the Batak children, many of whom have become prominent figures in the political and economic life of Indonesia.

Farmers cultivate haminjon toba trees under the forest shade, taking great care to encourage their growth. They also plant other useful trees such as petai, mango and rambutan, while closer to the huts, bananas and chili plants can often be found. Some farmers also grow coffee, cinnamon and rubber but benzoin remains the most important product in these special gardens.

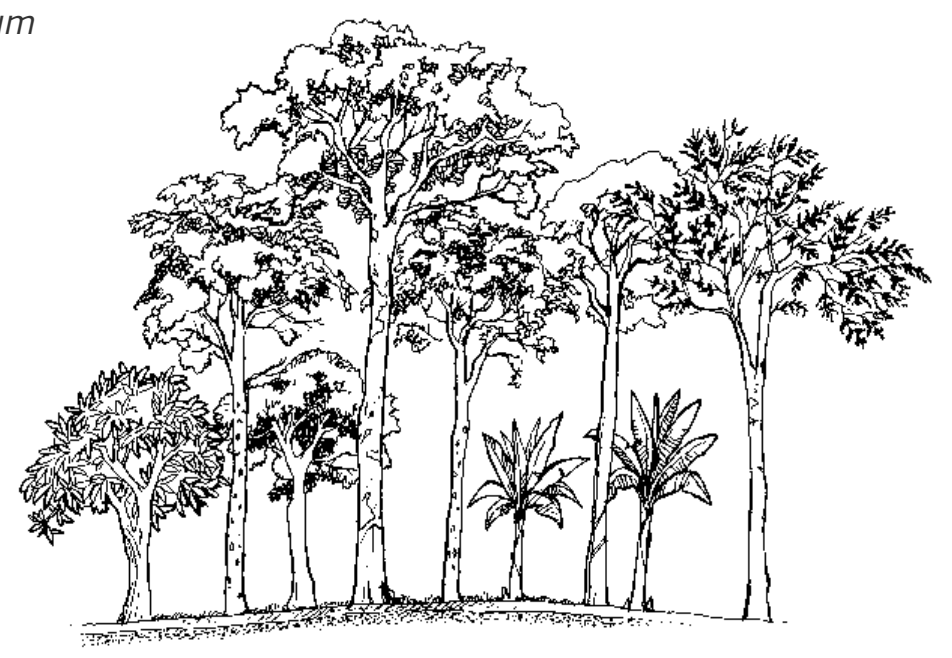

Cultivated trees for benzoin resin are grown in beautiful 'benzoin gardens'. The trees' numerous tapping scars are easily recognised when walking through these forested areas.

\section{Benzoin cultivation and tapping}

Benzoin plantation densities range from 100-500 trees per hectare, with the gardens including different species of Styrax but mainly S. paralleloneurum. Farmers favour its growth, establishing seeds or seedlings under the forest cover and eliminating competing species, progressively modifying forest composition in the process. Tapping usually begins

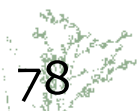


around the eighth year of growth, coinciding with the first flowering event and the trees may then be tapped for more than 60 years.

Benzoin farmers need to be strong and agile as they shimmy up the trees 5-6 m, carrying special tools to make the bark incisions. Tapping is done manually once a year. First, you have to clear competing vegetation using a machete. Then, with the 'guris', moss and lichens are scraped from the section of trunk you want to tap. Dead bark is removed from the previous year's tap wounds with the 'agat pasitahir', and a special knife, called 'agat panuktuk', is used to create 20-30 new $2-3 \mathrm{~cm}$ incisions. A farmer can prepare five to eight trees a day in this way and three months later they collect the first flow of resin (which yields the best quality). On average a farmer can collect $2-3 \mathrm{~kg}$ per day in a rattan basket or 'bakul'. The fresh resin is quite soft, like sticky toffee with a slight vanilla-like scent. The trees produce two to three flows a year, totaling around 200-500 gm per tree.

\section{The local setting and marketing}

In North Sumatra, benzoin production involves more than 100 villages and 18,000 families. Benzoin resin contributes on average US\$ $144-216$ or $30-45 \%$ of total annual household income. In every step of the trade chain, the benzoin is dried, cleaned and resorted or processed, adding value to the product. Those involved include farmers, village collectors, regional and inter-island traders, retailers and exporters. Women are not directly involved in resin collection although they sometimes trade the product and have an active role in managing the earnings.

The Indonesian market consumes three quarters of the total Sumatran benzoin production, while the remaining quarter is exported, mainly through singapore. Some of the best quality resin makes its way to the perfume and pharmaceutical industries of Europe but incense production represents the main usage both domestically and internationally.
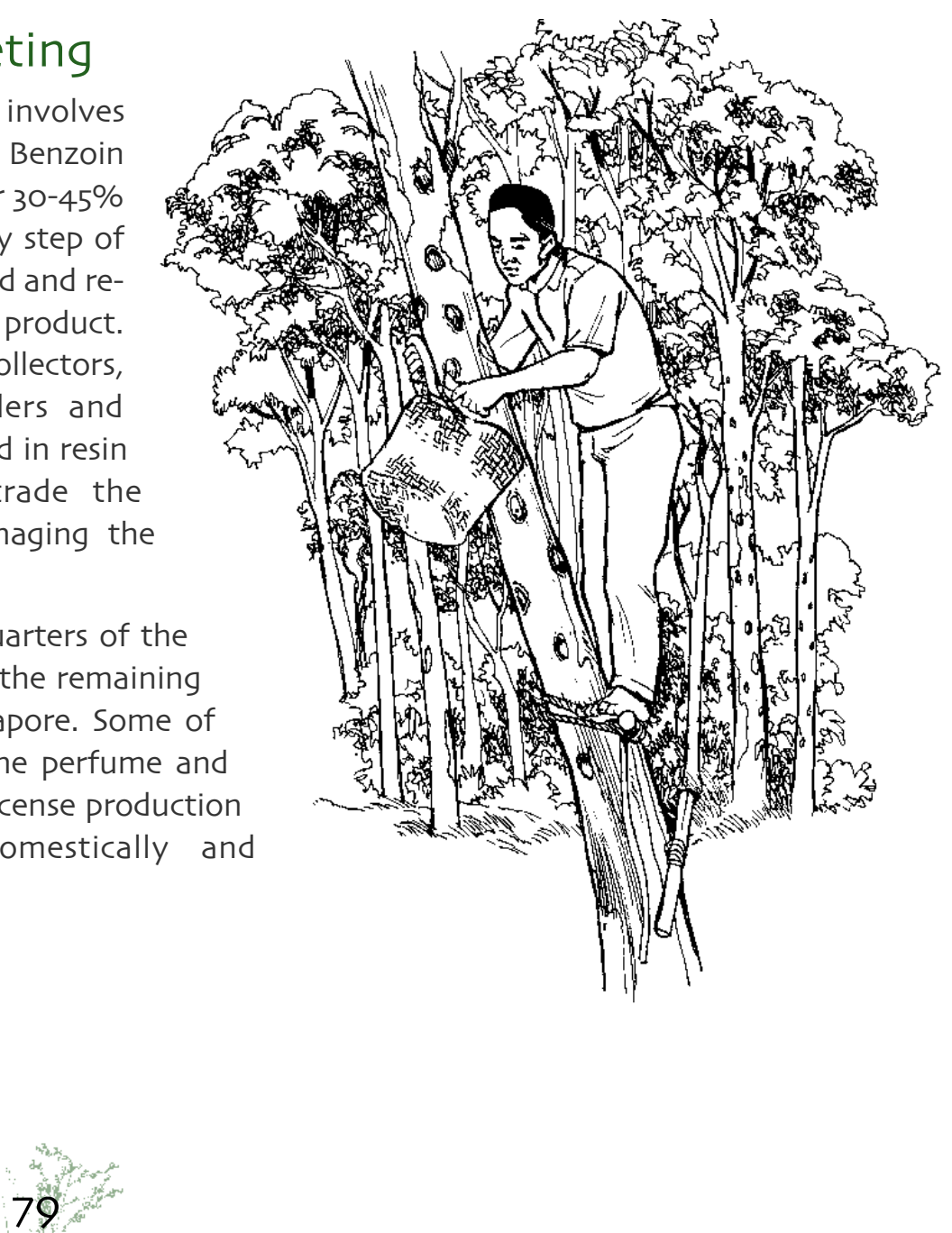
Benzoin incense is used in traditional ceremonies and rituals as a link to the spiritual world. This incense is rarely pure though, as resin factories mix the benzoin with damar resin and other ingredients to make incense blocks. These burn more slowly and reduce the final price. However, at some events, such as Chinese New Year celebrations or Javanese ceremonies commemorating important phases of the life cycle, high quality unadulterated benzoin is burned.

Benzoin resin is also added to the tobacco of traditional cigarettes called 'Klembak menyan' and it is used as a flavouring agent in the clove cigarette industry (an important national market producing 140 billion cigarettes in 1993). Pharmaceutical preparations use benzoin resin as an antiseptic and an expectorant tincture for bronchitis and laryngitis, while in China it remains an important component in traditional medicine.

From the Tapanuli Utara district in North Sumatra, the key growing area, around 4,000 tonnes of benzoin resin were traded in 1998, valued at US\$ 4.8 million. However, in spite of its economic uses and historical importance, a growing number of families are abandoning benzoin cultivation. Many younger people perceive it as old fashioned and are shifting to coffee, cinnamon and other cash crops, viewed as more 'modern' and lucrative. The future of the benzoin gardens and their resin depends on the modernisation of some of the resin's end uses and the maintenance of competitive prices, stable markets and land tenure security. Current trends indicate the trade is declining as a result of benzoin's replacement

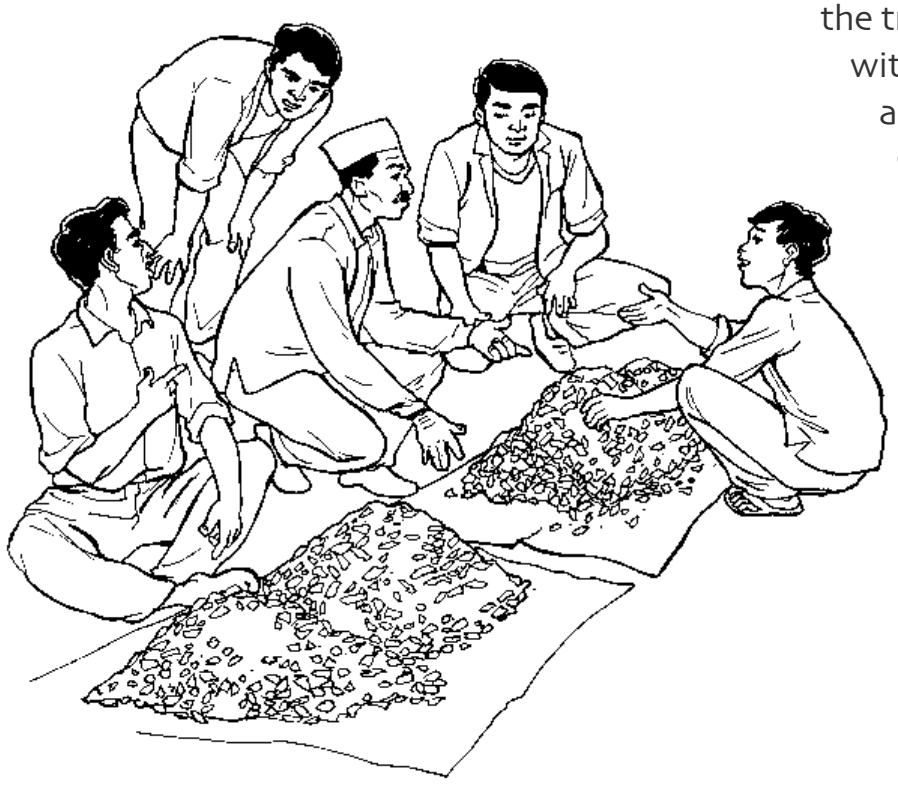

Buying and selling benzoin calls for time, patience and experience. Traders depend on their knowledge about resin to make a profit, determining the composition of the benzoin mixture and identifying which qualities are present. At the farmers' level, there are four qualities and up to 16 in the big regional markets. and farmers shifting towards other activities. Combining benzoin with more profitable crops, improving tapping techniques and exploring niche markets for sustainable, organic* commodities could signal the way forward in making the most of the existing marketplace. 


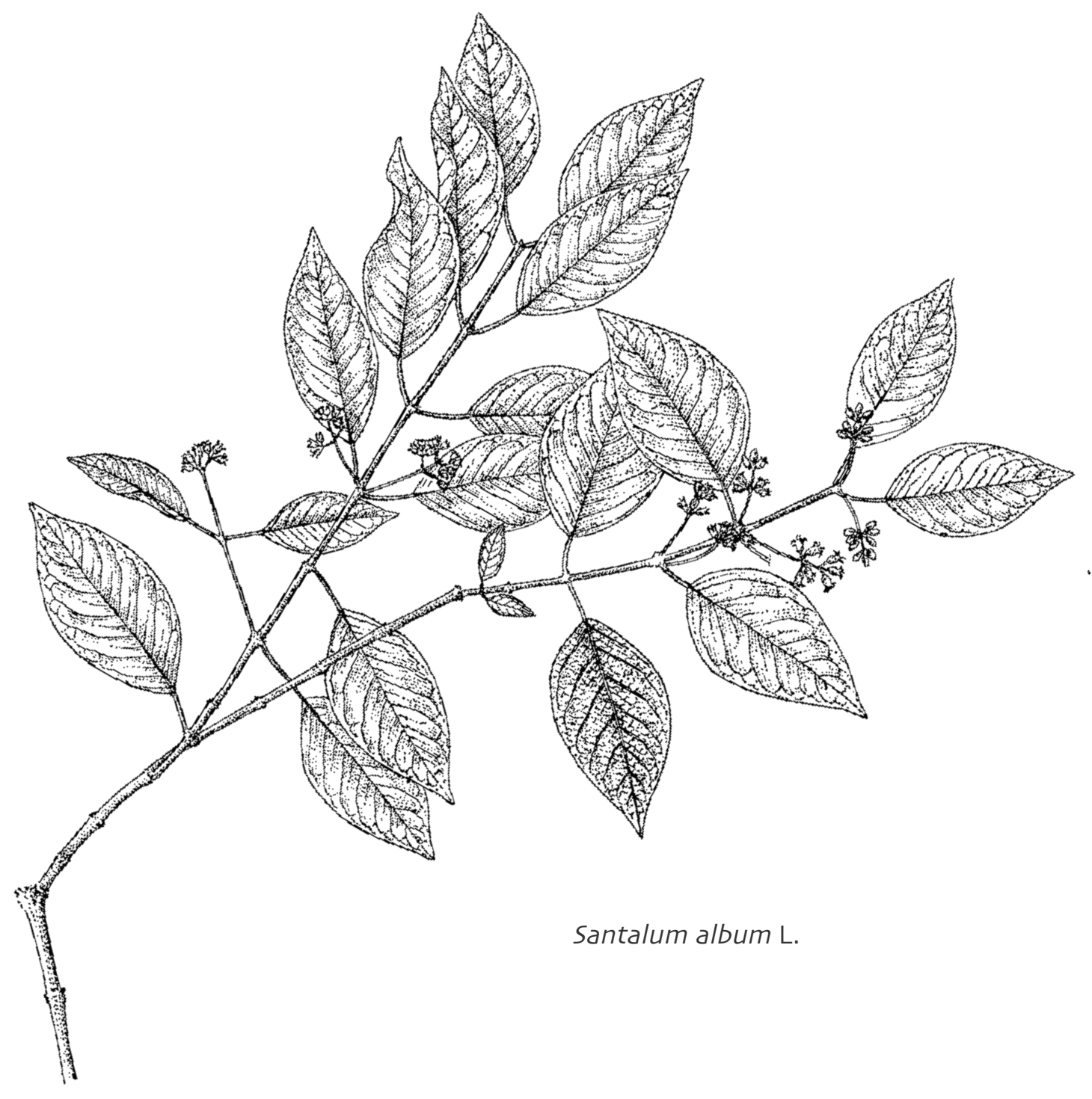

\section{Sandalwood, oil and handicrafts}

Indonesian case by Dede Rohadi and Retno Maryani 


\section{Sandalwood: A fragrant yet troubled history}

In Indonesia, sandalwood is known as 'cendana' but it is also called 'hau meni' or 'kayu wangi', meaning 'smell wood'. A less flattering name is 'hau lasi' or 'problematic tree' - a term relating to this tree being the centre of many conflicts involving the community, local rulers and government. People compete to possess the precious sandalwood trees for their own benefit, sometimes using illegal actions or even coercive force.

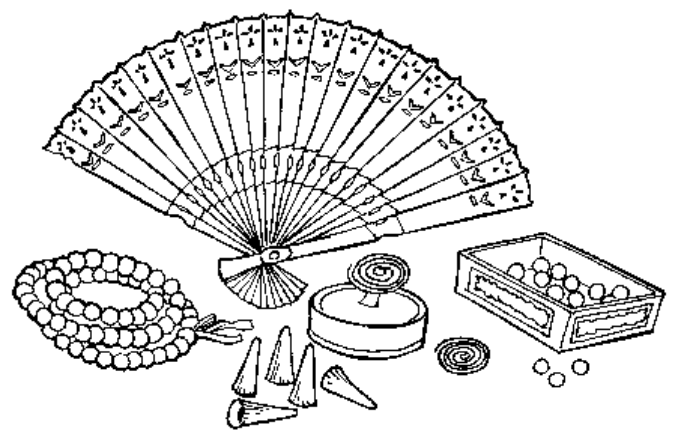

Sandalwood is used locally or on neighbouring islands (such as Bali), for woodcarving and the making of various handicrafts and incense.
Sandalwood is a well known woody species originating from Indonesia's Timor region. Its wood has a beautiful scent and in shops throughout Asia, passers by often stop to enjoy the fresh forest aroma of sandalwood fans, pens, beads and rosaries.

Sandalwood oil is also highly cherished, with a long history of use in perfumery and cosmetics and established markets in the United States of America, Singapore and Europe. Oil from the Timorese Santalum album is more sought after than that of other Santalum species because of its high santalol content. It is extracted from the heartwood* of stems, branches or roots from mature trees.

\section{A royal history}

The history of sandalwood in the East Nusa Tenggara province (which includes the Timorese islands) closely parallels the history of the province itself. Prior to the tenth century, Chinese traders were already marketing the wood commercially to Malaya and India. During the fifteenth century, sandalwood attracted western traders as well and may have been one of the stimuli for colonisation in Indonesia.

Historically, under traditional law, the ruling class appropriated the region's sandalwood trees and the king (radja') was said to own them all - regardless of whose land they grew upon. To control the sandalwood, the king would appoint a regional ruler (fetor' or 'uis pah') who in turn, would assign a local chief (adat') to administer rules governing sandalwood and oversee 
ritual harvesting ceremonies. The proceeds from the root would go to the radja, the stem to the fetor and the branches to the landowner.

During the era of Dutch control, the colonial government monopolised the sandalwood trade. Then, following independence in 1945, the regional government controlled the wood (and generated income) through a series of regulations governing its management. In recent decades, resource inventories have been conducted every five years to determine the annual cutting rate. Due to an alarming level of resource depletion, in 1997 sandalwood cutting was banned for five years to allow for regeneration. This followed a 'sweeping operation', which had collected 2,000 tonnes of illegally harvested sandalwood. The ban forced local oil and handicraft industries to obtain supplies (of around 4,000 tonnes a year) from elsewhere, including the black market and imports.

\section{Sandalwood trees}

Sandalwood is an evergreen* tree that grows 12-20 m high, with many irregular branches and an average trunk diameter of $25-40 \mathrm{~cm}$. It is usually found in small groups of 4-5 trees and is generally harvested for its wood after about 15 years. The province's stocks come from naturally regenerated trees, mostly from coppicing* but also from new seedling growth. Historically, there have been several attempts to establish plantations but without much success - although countries like India could provide a better example to follow. Forestry plans currently have sandalwood trees being planted out with other species like teak, candle nut and jack fruit and new trial plantations and experimental nurseries are being established.

Harvesting is normally carried out during the dry season (August-October). Ideally, the first cutting obtains heartwood from the stems and branches, while the roots are dug out two or three years later. Forestry staff or village labourers harvest state owned land, while farmers cut the trees on their land (with the government paying them a percentage of the royalties).

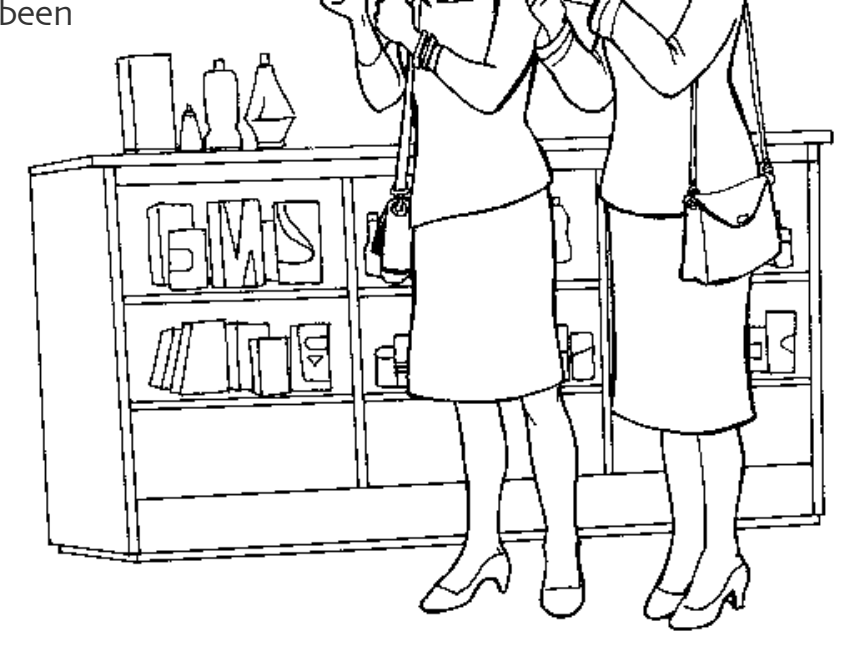

Fragrant sandalwood oil is popular around the world as an ingredient in perfumes and cosmetics (and is also used in traditional medicine). 
Standard practice has seen the government harvest and distribute the wood to processing industries in East Timor and Kupang (the province's capital, on Timor Island). Wood allocation is based on processing capacity and the availability of raw material, with payment in advance. The sandalwood oil industry consumes the most material and its sawdust by-product, along with that of the local handicraft industry, feeds another local production - incense making.

The price of sandalwood has fluctuated but just prior to the cutting ban in 1997, high quality wood fetched around US\$ 2.17 per $\mathrm{kg}$, with lower grade wood ranging from US\$ 0.06-1.84. The Ministry of Forestry decides on the royalties paid, which in 1997, were US\$ 0.04 per $\mathrm{kg}$ for wood and US\$ 0.13 for oil. Figures for sandalwood oil from 1983 to 1992, reveal an export volume ranging from 5.3-21.9 tonnes per year, with the price fluctuating between US\$ 75-152 per kg.

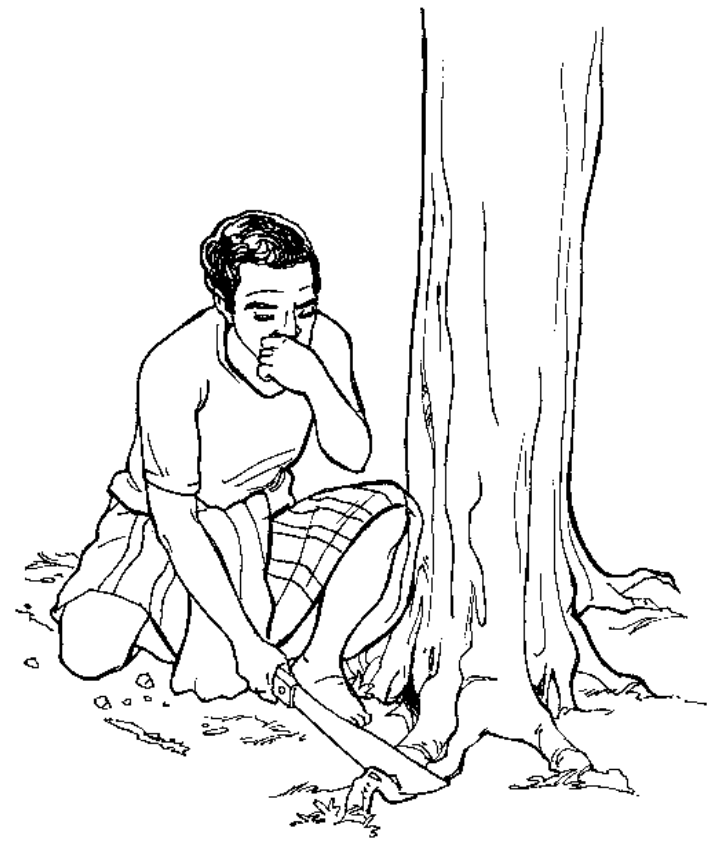

As higher quality oil can be extracted from sandalwood roots, harvesters often compete to dig them out, damaging the trees and jeopardising regrowth.

\section{Future direction}

A lack of incentives to maintain sandalwood trees and high rates of illegal cutting are largely responsible for the sharp decline in this resource, while frequent burning, shifting cultivation* and wild grazing have also led to a regeneration rate too low to replenish stocks. Government regulations intended to maintain resource sustainability have actually had the opposite effect - as the current situation shows. The result: a loss of raw material for local industries and also, one of the region's most important sources of income.

A recent Governor's decree states that management of sandalwood trees will now be regulated at the district level. However, this change has not yet motivated people to plant and maintain trees due to past experiences and the uncertainty of land and tree tenures. The future of sandalwood in Timor will depend on the effort that goes into planning for future supplies, developing plantations and encouraging people to foster natural regeneration. 


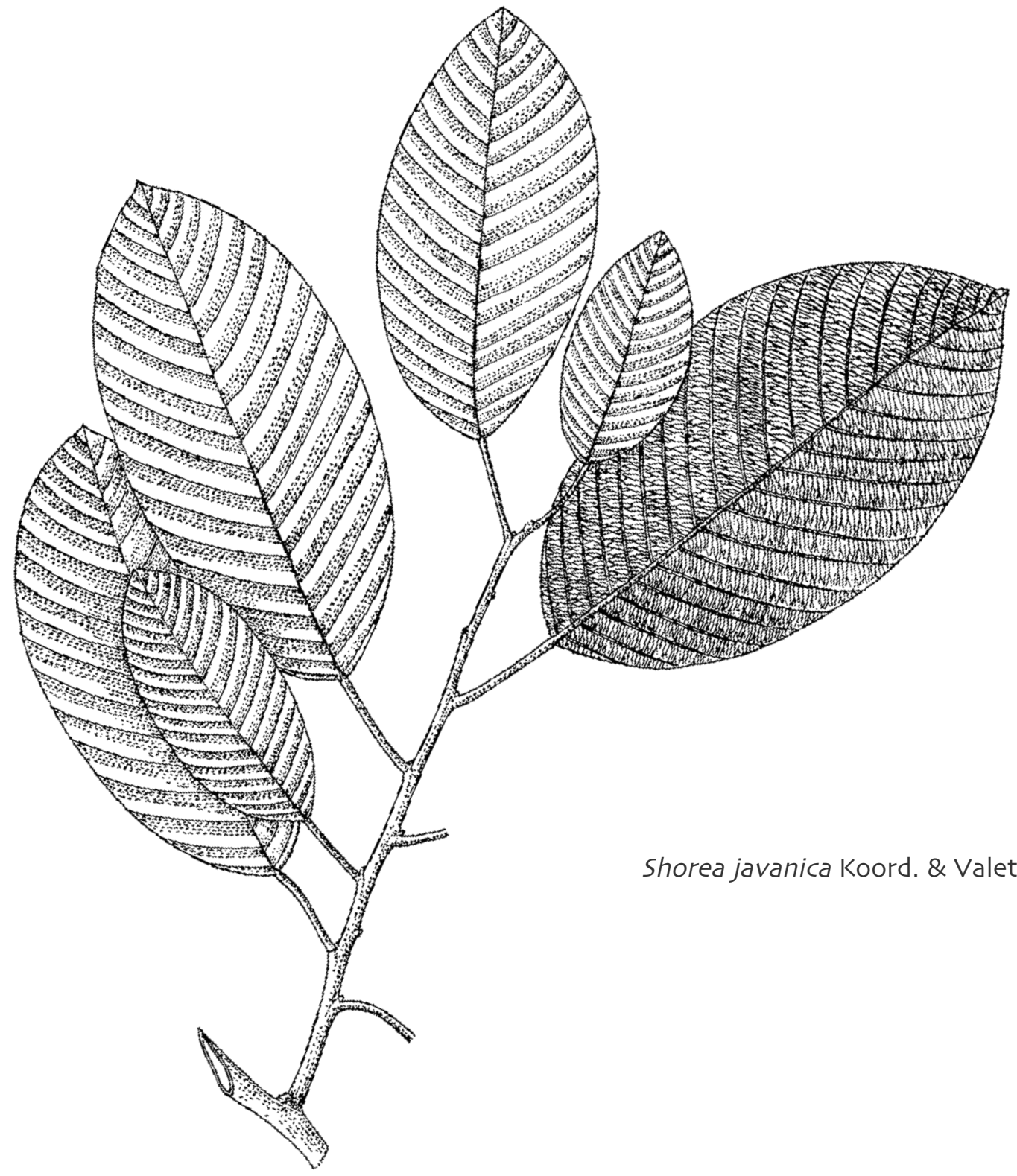

\section{Damar resin}

Indonesian case by Hubert de Foresta and Geneviève Michon 


\title{
Damar resin: From tree farms to torches, batik and varnish
}

\begin{abstract}
'Damar' is a generic Indonesian name for resins - sticky plant exudates produced by around 115 different types of forest trees. These resins vary in quality, with the clear yellowish 'damar mata kucing' (meaning 'cats eyes'), produced by Shorea javanica, considered as the best. Damar was initially used for lighting torches, making batik dyes and incense, and sealing seams in boats to render them watertight. Since the mid-eighteenth century, it has also been used in the paint, ink and varnish industries and more recently, as an additive in sodas.

Owners of 'damar gardens' as they are known, obtain benefits from the resins and also from the various fruit and timber species that are planted together, in a form of agroforestry". Local people say they can live well with 2 hectares of damar gardens and are considered quite rich if they have more.
\end{abstract}

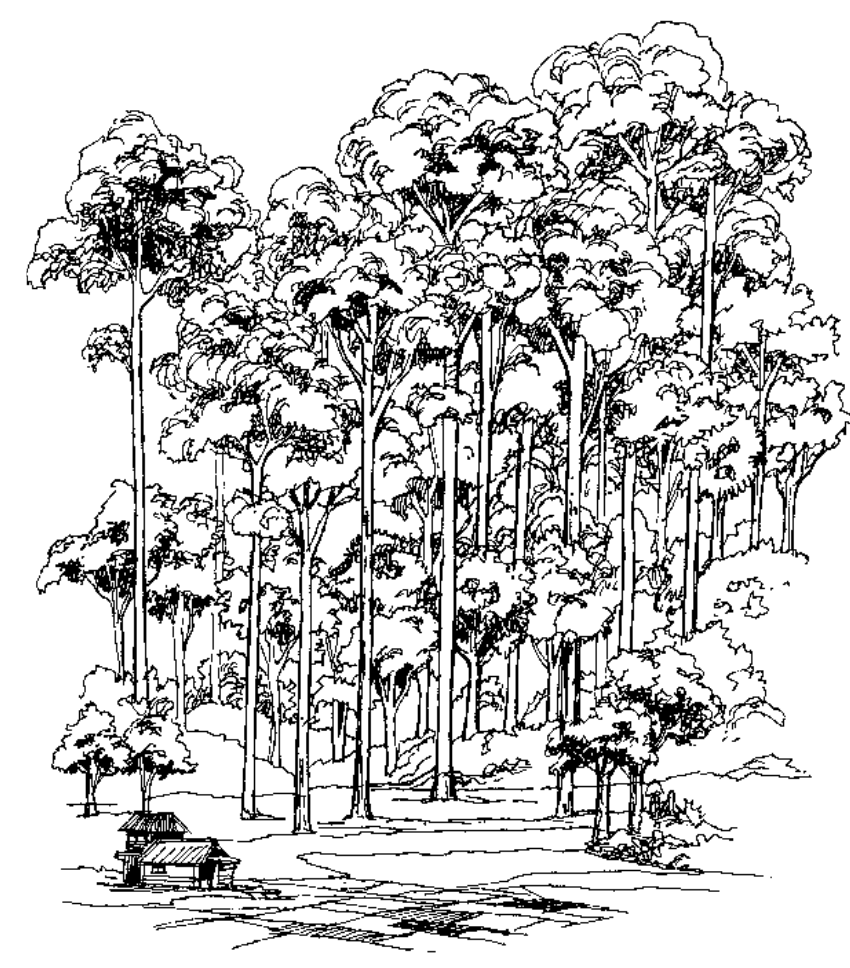

\section{Trading damar - past to present}

Damar resins have been traded between South East Asian islands as far back as 3000 BC and they were probably included in the first long distance exchanges with China in the third to fifth centuries. The first exports to Europe and America commenced around the 1830s. Nowadays, Indonesia is the only country in the world producing damar from planted trees, with Krui, in Lampung, the southern-most province of Sumatra, as the centre of production. This area produces about 10,000 tonnes of damar mata kucing each year, accounting for more than $80 \%$ of national damar production. The best grades are exported (about one third of production) and the remainder is used within Indonesia, mainly in the handmade batik industry and in incense production, where damar is mixed with benzoin resin.

S. javanica is a tall tree that can grow to $50 \mathrm{~m}$, with a $2 \mathrm{~m}$ diameter. It is native to lowland forests in Western Sumatra, where it is now found planted by villagers in dense stands, along with other useful trees. 
In the Krui area, as in many other places, damar trees would be tapped in the rainforest. By the end of the nineteenth century however, the area's damar resources were nearly exhausted. In response, some innovative farmers planted damar tree seedlings into their mixed coffee and pepper plantations, along with fruit trees. Their early success led to a long lasting wave of damar planting amongst local farmers - which has continued until the present day. In 1998, damar agroforests covered more than 50,000 hectares. For nearly three quarters of the area's 70 villages, damar agroforestry represents the main land use - providing $60-80 \%$ of household income.

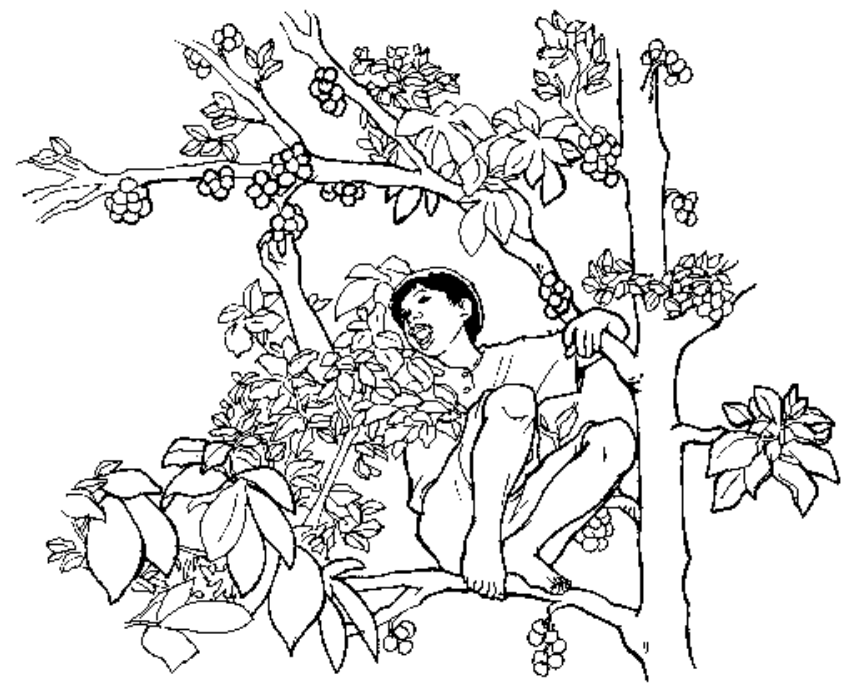

Within the damar gardens, everyone can enjoy harvesting and eating fruits, like duku (Lansium domesticum).

\section{Establishment of damar agroforests}

The establishment of damar agroforests involves three main production phases, with plantings continuing throughout the cycle to ensure replacement stock and permanence of the damar phase.

\section{The swidden* upland rice phase}

Damar tree seedlings are planted in the swidden along with upland rice and vegetables, and coffee, pepper vine and various fruit tree seedlings. For the first 1-2 years, production is centred on rice and vegetables.

\section{The coffee/pepper plantation phase}

In the third year, coffee production begins, lasting 10-15 years. Pepper begins producing around the fourth year and continues for another 8-12 years. Certain early producing fruit trees, like jackfruit and rambutan, also bear fruit after 3-4 years, while late producing species, like duku and mangosteen, start to fruit after 10-15 years.

\section{The damar agroforest phase}

Damar trees reach a tappable size after 15-20 years. This marks the beginning of the damar garden phase, in which resin becomes the main commercial product, along with fruits.

In the Sumatran agroforests, damar, fruit and timber trees all provide important sources of family income.

Resin: Damar trees are generally tapped once a month. The resin is sold directly to small scale traders in local warehouses in the agroforest area itself or to medium scale traders in the 
village. These traders carry out initial grading before transporting the resin to larger scale operators in Krui or Bandar Lampung, the province's capital. There, the damar is graded once again before being sent to Javanese factories, large scale traders in Singapore or directly to overseas companies. For producers, damar collection provides regular income to comfortably cover daily expenses.

Fruits: In the Krui area, fruit trees bear significant yields about once every 2-3 years (e.g. duku, ketupak and durian). A few species fruit every year (e.g. jengkol and tangkil) or even all year round (e.g. petai). As the transportation network has considerably improved over the past decade, the commercialisation of fruits from the agroforests has become increasingly important economically for damar producers. Durian and duku fruiting seasons can triple a family's annual income!

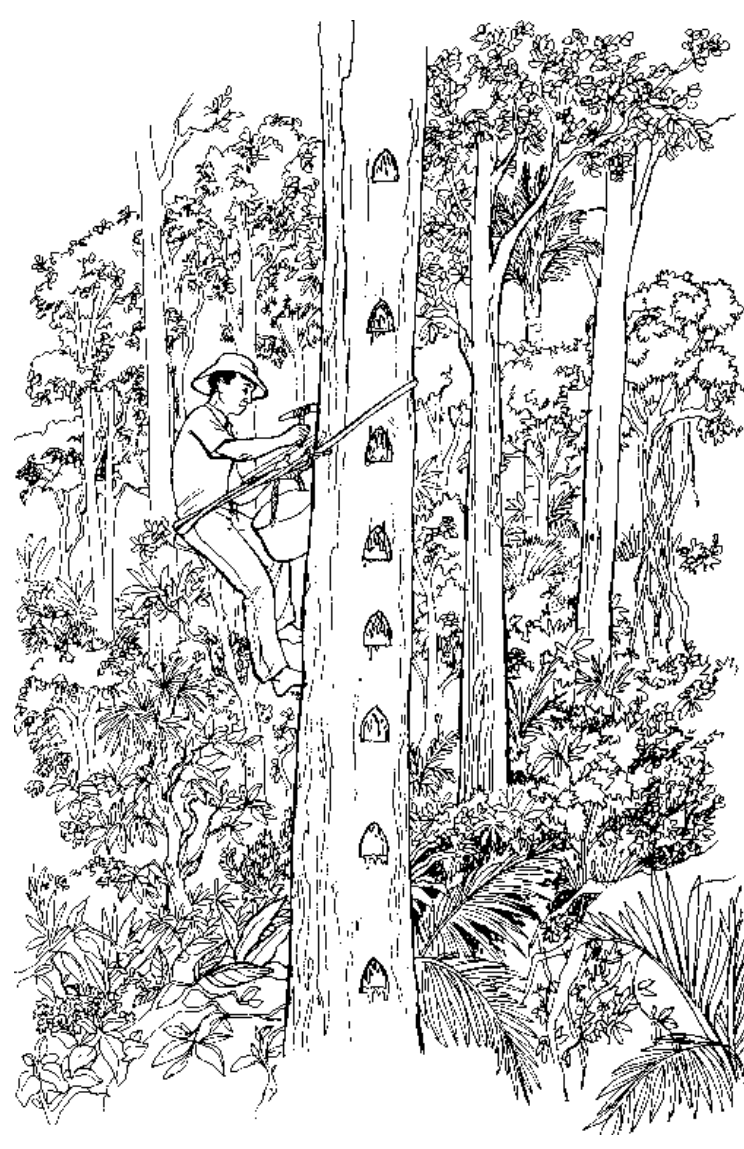

Tapping damar - skilled farmers climb the tall trees and break up the glassy, hard resin with a special hammer, collecting the damar into a rattan basket.
Timber: Since the early 1990s, with the availability of chainsaws, timber harvesting in and around damar agroforests has grown in importance. This additional economic activity is run and well controlled by local communities. 'On the spot' processing occurs for naturally fallen trees, trees reserved or planted for their timber or unproductive damar and fruit trees. For trees that need to be felled, chainsaw operators have developed 'directional felling' techniques, since they have to pay the damar agroforest unit owner significant fines if they damage or destroy other trees. Timber harvesting does not yet generally represent a major contribution to the damar producers' annual income, however it may help pay for exceptional expenses, such as medical costs or wedding ceremonies.

\section{No wonder damar is a success story}

The damar agroforest systems have existed for over 100 years. They have adapted to changes in the economic value of associated products, such as fruits and more recently, timber, and have also survived a number of economic crises. Over time, they have become an integral part of the culture of the Krui area's inhabitants. Through integrating damar trees into their cultivation system, farmers not only domesticated" the species and multiplied the damar resource, they re-created a rich and complex forest ecosystem* - one that fits their economic, social, environmental and cultural needs and can be passed on to future generations. 


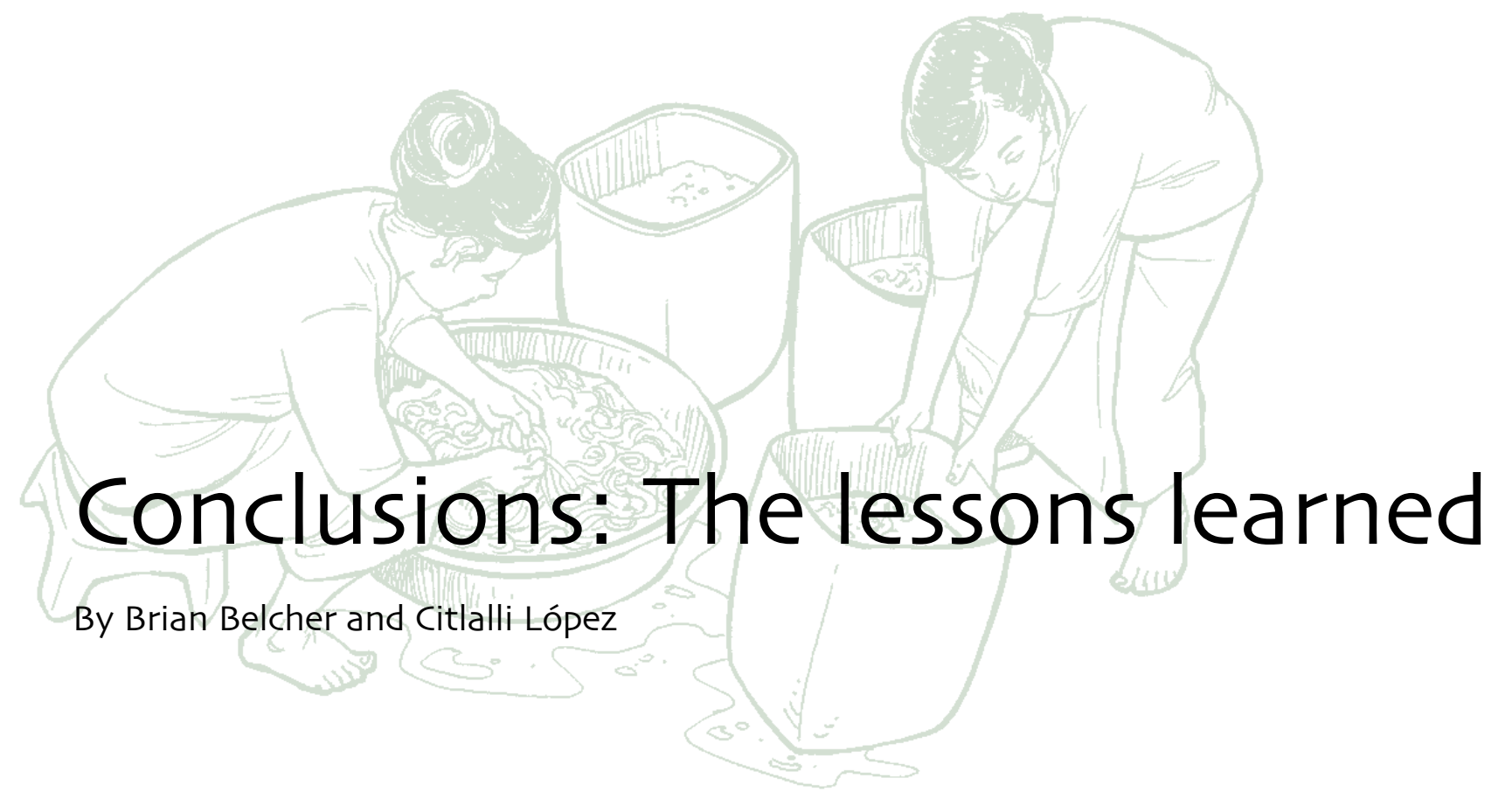

The cases within this volume demonstrate a great deal of variability, as well as some striking similarities. As such, they are valuable for what they teach us both individually and collectively. By comparing and contrasting different cases we can gain a greater understanding about the characteristics of small scale natural resource management, the broader socio-economic context and also, policy and investment interventions that may lead to successful outcomes or failures. This final chapter discusses some of the key issues and lessons learned about the value of forest resources, their sourcing and management, demand and supply, and fair and sustainable trade.

\section{The value of forest resources for rural families}

Rural livelihoods, especially in developing countries, are characterised by diversity. Households rely on the direct use of agricultural and forest goods as well as many different sources of cash income, generated from the sale of produce or wage labour. Three categories of households involved with non-timber forest products (NTFPs) can be identified according to the degree of household income earned in cash and the proportion generated by the trade of NTFPs.

- Households primarily relying on subsistence sources (direct use) of forest goods

- Households in which the commercial NTFP provides a supplementary source of income

- Households that earn most of their income in cash, from the sale of a forest product 
Subsistence uses

(food, medicine,

raw materials for

domestic and

agricultural

utensils, building

materials, etc)

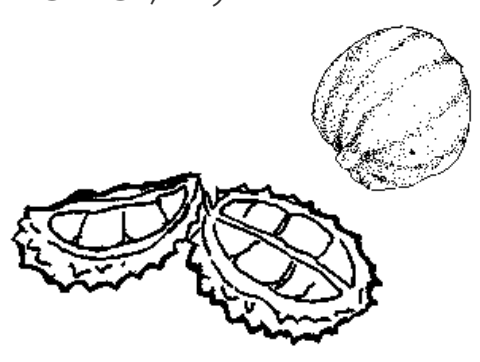

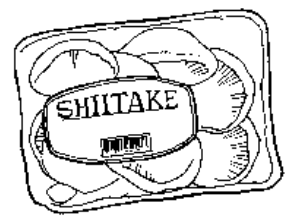

Commercial uses (exotic food, medicinals, raw material for handicrafts, components of industrial

products, etc)

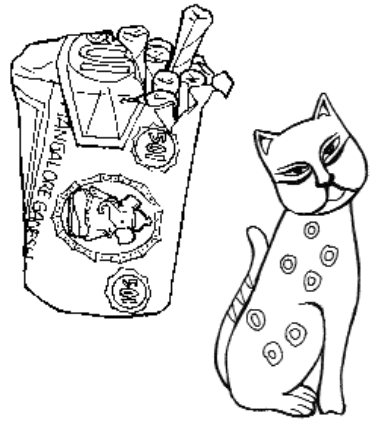

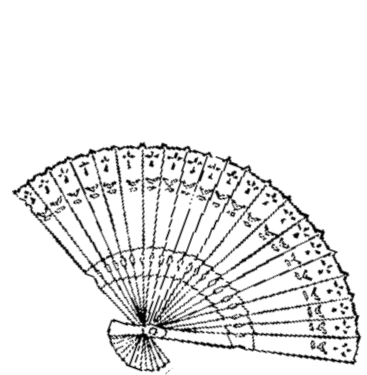

Forest products are used both to meet subsistence needs and to generate income

The latter group of more specialised producers tends to deal with products that have large, often international markets, and those involved generally manage their NTFPs relatively intensively. Some of the more long-lived species, such as durian and trees that produce damar resin, may even be used as a form of savings, insurance or collateral for loans. Commercial value however, is not the only reason families conserve and manage forest resources. For instance, certain trees or managed gardens (e.g. of rattan, or Styrax trees - from which benzoin resin is obtained) may be used to signal land ownership. Many products also have value as sources of medicine, and/or for ritual purposes, such as lapsi trees in Nepal and honey bees in the Philippines.

\section{From where do our forest products come?}

Some products, such as tout tiang bark and song rong mushrooms, are collected from wild sources within forests. Other products are managed more or less intensively, and some are truly domesticated* and cultivated beyond their natural range of distribution. Over centuries, farmers have patiently experimented, planting valuable species close to their settlements, on farms or in agroforestry* systems, home gardens and back yards. Some species are grown with agricultural crops, either at the same time or in successive plantings on the same land. Others are grown in combination with other useful woody and herbaceous* species. Farmers sometimes combine so many species that their plots start to resemble tracts of forest, taking on many of the same functions - including providing habitat for a variety of other plants and animals. In some cases, producers adopt much more intensive approaches, growing products in monoculture* plantations, as is the 
case for durian in Thailand, or in greenhouses, as for the oak mushroom in Korea (and more recently in the United States of America and some European countries).

To satisfy consumer tastes and supply larger quantities of products for burgeoning markets, farmers have also modified the characteristics of certain species. For example, by selecting or breeding to change the size, flavour or colour of the product, improve consistency or shift the fruiting period. Production is also enhanced by applying specific management practices, such as pruning to encourage the sprouting of young tendu leaves, which are used in the production of beedi cigarettes in India, or through improving the early identification of female lapsi trees - the ones that fruit - in Nepal.

The management options open to producers range along a continuum from low to high intensity. Valuable species may be:

- Collected from wild populations, with no management

- Encouraged, protected and otherwise managed in natural forests

- Managed along with other useful forest species (e.g. rattan, damar producing trees in Indonesia)

- Tolerated (allowed to grow naturally and not weeded out) in agricultural lands

- Cultivated in agricultural lands in combination with other cultivars* (e.g. lapsi tress in Nepal, cardamom in Laos)

- Managed in small plantations (e.g. paper mulberry in Laos)

- Grown in large monoculture plantations (e.g. bamboo in China)

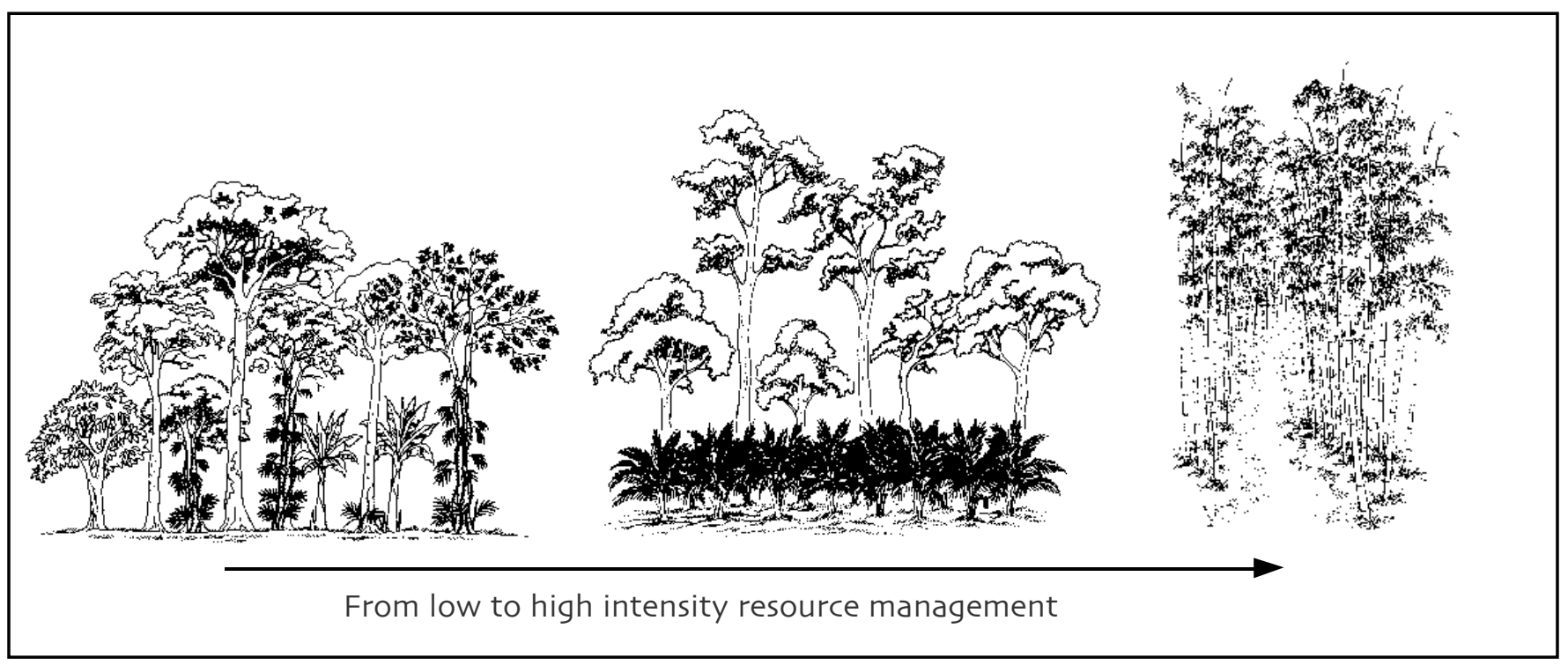




\section{Harvesting, transporting and trading forest resources}

For many rural families, the harvesting of forest resources is a seasonal activity which fits in around other work demands. The gathering of kroto larvae for example, is secondary to rice farming activities. For those with time to invest in collecting, forest resources are available at low cost - a characteristic which is of particular importance to the poor. As seasonal products, most of the resources covered in this volume provide important supplementary income to add to agricultural or other income sources. In many cases, the income generated from the sale of forest products is used for important expenditures such as school fees or medical treatment. For products producing a higher share of household income, as is the case for woodcarving in Bali and swiftlets nests in Indonesia, collectors tend to invest a greater proportion of their time.

After harvesting, the resources have to be transported to their point of sale or processing. As with the old real estate motto, location is everything! The distance to markets, the availability of roads and rivers, and the means of transport all influence whether and how producers market their produce. The harvesters' families or other local processors immediately process some forest products - especially those that are prone to spoiling, and bulky or heavy products with a low value. Processing increases their durability and concentrates value. A great number of women are involved in the processing phase, obtaining important income for their families.

Products are moved to market individually on producers' backs, atop bicycles or motorcycles, or using available public transport. Sometimes forest products go directly from harvester to consumer, which can work well if the buyers want small volumes. But for many products this approach can disadvantage the sellers, who may be forced to accept low prices on a "take it or leave it" basis, particularly if they are far from home. More commonly, marketing is organised by intermediaries who purchase the product from harvesters and transport it to trading centres, larger traders or processors. Although 'middlemen' are often seen as rural robbers, traders frequently provide important services that are otherwise unavailable - like transport and marketing, loans against future production, and the provision of essential goods and information to remote villagers. As in the cases of cardamom, benzoin and agarwood, traders can also be important repositories of detailed knowledge regarding specific forest products. They often work hard to earn a modest profit while carrying a considerable share of risk - prices may fall by the time the product reaches market, a proportion of the shipment may spoil or the whole lot may be confiscated by forest guards.

\section{What happens when demand and supply change?}

Demand has increased for many of the products outlined in these cases, although there are also examples of remarkable volatility. Uppage fruit in India demonstrates a boom-bust cycle, with the boom caused by a dietary fad in the United States of America, and the bust occurring when scientific evidence showed that the product was not as effective a weight loss agent as first believed. Indonesian rattan also experienced a boom, with increasing export demand at a time when other rattan producers were running short of raw material, and then a bust caused by misguided policy. 
Demand is typically greater in international markets. Some products, such as cardamom, tout tiang bark and swiftlets birds' nests, have historically been traded outside their production areas. Trade in mulberry paper, song rong mushrooms and durian have also extended beyond local and country borders. An increase in the size and wealth of such international markets can lead to a rise in product demand. The individual cases show that when this occurs, changes take place in terms of harvesting, processing and marketing practices.

Increased demand stimulates producers to pursue various strategies to increase production. With wild resources, harvesters first intensify their collection practices. Especially when there is "open access" to forest (i.e. the unrestricted use of resources, with no effective property rights) and different harvesters compete for the same resources, there is a tendency for harvesting methods to become ever more destructive - such as felling trees to access the bark or fruit, as in the uppage and sandalwood cases. However, this limits the species' ability to reproduce, resulting in reduced future supplies. Similarly, immature specimens may be gathered, even when they do not attain the best market price (e.g. song rong mushrooms in China, agarwood in Indonesia). When resources become extremely depleted in a given area, harvesters may begin traveling long distances to more remote locations in search of new supplies.

Traditional rules often provide guidance over access rights and help to protect resources. However, in situations of conflicting claims (e.g. between the State and communities) or as demand and prices for forest products increase, traditional rules can break down. To address the issue of over-

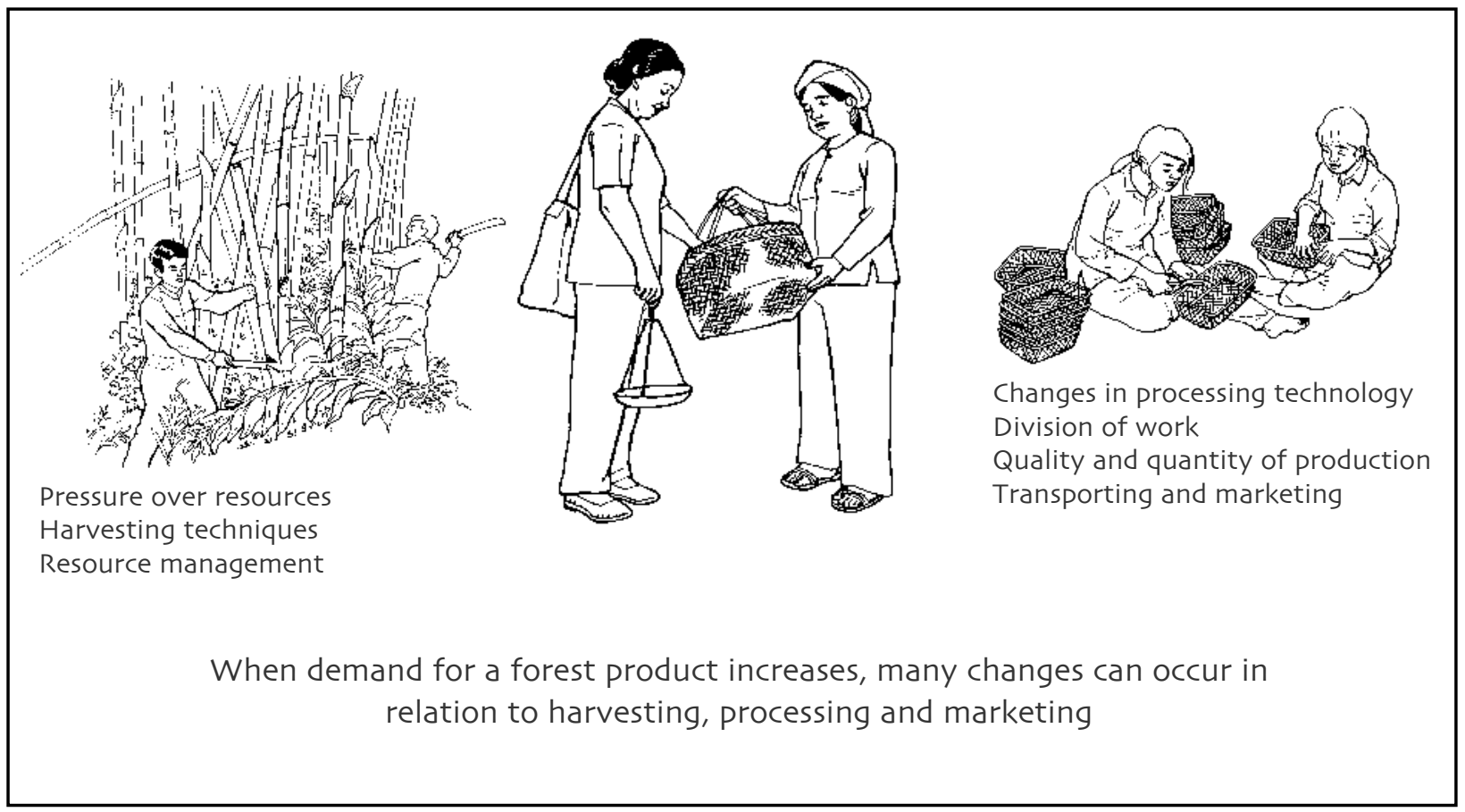


exploitation and ensure a continued supply, farmers may intensify the management of valuable species. Together, a number of factors favour the process of domestication: significant demand, high market prices, secure tenure and appropriate ecological conditions.

Increased demand often leads to the specialisation of tasks. Sometimes this involves the abandonment of traditional manufacturing methods in order to produce larger quantities - and this can result in lower quality end products and lower market prices (as in the case of woodcarving in Bali). Some processors and even some countries may specialise in only one or certain steps of the manufacturing chain. For example, Laos supplies the raw material for hand made mulberry paper, while the processing of the bark fibres takes place in Thailand.

Contrary to what most consumers would imagine, growing demand for forest goods does not always result in improved incomes for rural collectors, processors or traders. In fact, sometimes conditions for the rural poor may even worsen. Increasing demand and more profitable commercialisation can:

- Diminish the supply of and access to forest products for families who depend on forest goods for their own use or for sale

- Result in diminished resource access for small farmers who lack control or ownership over land and/or resources, shifting access to more powerful individuals or groups who have land rights and capital to invest

- Favour domestication efforts which involve not the original forest-based producers but a new set of producers with greater access to agricultural land and planting technologies

\section{Fair and sustainable trade of forest goods}

Due to the complexity and potentially negative impacts for small producers, plans to enhance commercialisation or intensify the production of forest goods need to bear in mind the wide range of potential impacts. Forest products are often sourced unsustainably, or their value is inequitably shared among the many people involved in their collection, processing and trade. To work towards ecological sustainability and socio-economically just trade, international and national organisations have established several initiatives over the last two decades - including certification and the formulation of forest conservation policies.

Certification is a procedure whereby a written assurance is given that a product, process or service conforms with certain standards. For instance, several non-timber forest products, such as Brazil nuts and palm hearts, have been certified in Brazil and Mexico. However, very few harvesters overall have access to the financial resources or organisational framework necessary to pursue certification. Programmes for certification have mainly been developed for timber and agricultural products but four main categories are relevant to forest products as well, and consumers may encounter these kinds of labels when making purchases: 
- Environmental - e.g. the Forest Stewardship Council (FSC) promotes ecological sustainability as well as socially responsible forestry

- Health - e.g. the International Federation of Organic Agriculture (IFOAM) focuses on the avoidance of exposure to, and contamination by, chemical pesticides and fertilisers

- Social - e.g. the Fairtrade Labelling Organisations International (FLO) aims to ensure that there is a fair and equitable distribution of benefits to producers

- Quality - e.g. the International Organization for Standarization (ISO) and Good Manufacturing Practices (GMP) formulate international product standards and encourage quality assurance

In addition to efforts by non-governmental organisations such as those outlined above, many countries have formulated national policies for the conservation of biological diversity, including forest resources. The United Nations Convention on Biological Diversity (CBD), adopted in 1992, affirms that States have sovereign rights over their own biological resources, and provides a broad legal framework to structure access and benefit-sharing agreements. Since the management and use of many commercial forest products is based on indigenous knowledge, such agreements have been particularly relevant for the conservation of genetic forest resources and the protection of intellectual property rights.

\section{Building the knowledge base}

As the various case studies illustrate, it is critical that forest goods are recognised and valued not only for their short term economic benefits, but also for their cultural richness and the sustenance that they offer to tens of millions of rural and urban families worldwide. For centuries, non-timber forest products have played vital subsistence roles and this continues to be the case in developing countries. A range of products with commercial potential, as we have seen, also provide important sources of family income for those with few other choices, as well as for those with access to capital or land and the initiative to further market or commercialise a particular product. The ability of a given resource to continue meeting both subsistence and commercial needs however, largely depends upon sustainable* harvesting and management practices. Access to information to assist with things like resource management, equitable access, income sharing, product development and marketing can be an important part of this process and can help to ensure a longer term future for both the forest products and the people who depend upon income generated from their collection, processing and trade.

Research, such as that carried out in the course of compiling this volume, helps us to better understand and appreciate the importance and roles of forest products, and some of the factors that lead to positive or negative outcomes for resources and forest people. It is hoped that the lessons learned will add to the growing knowledge base about forest products and that this information can contribute to government and development policies, a general raising of awareness amongst consumers and also importantly, that it can filter back to the communities involved in the commercialisation of forest products, enhancing the traditional knowledge and skill base. Such information can better equip communities to improve their livelihoods in an environmentally sustainable manner - tapping into the riches of the forest in ways that can meet both short term and longer term subsistence, commercial, cultural and conservation needs. 


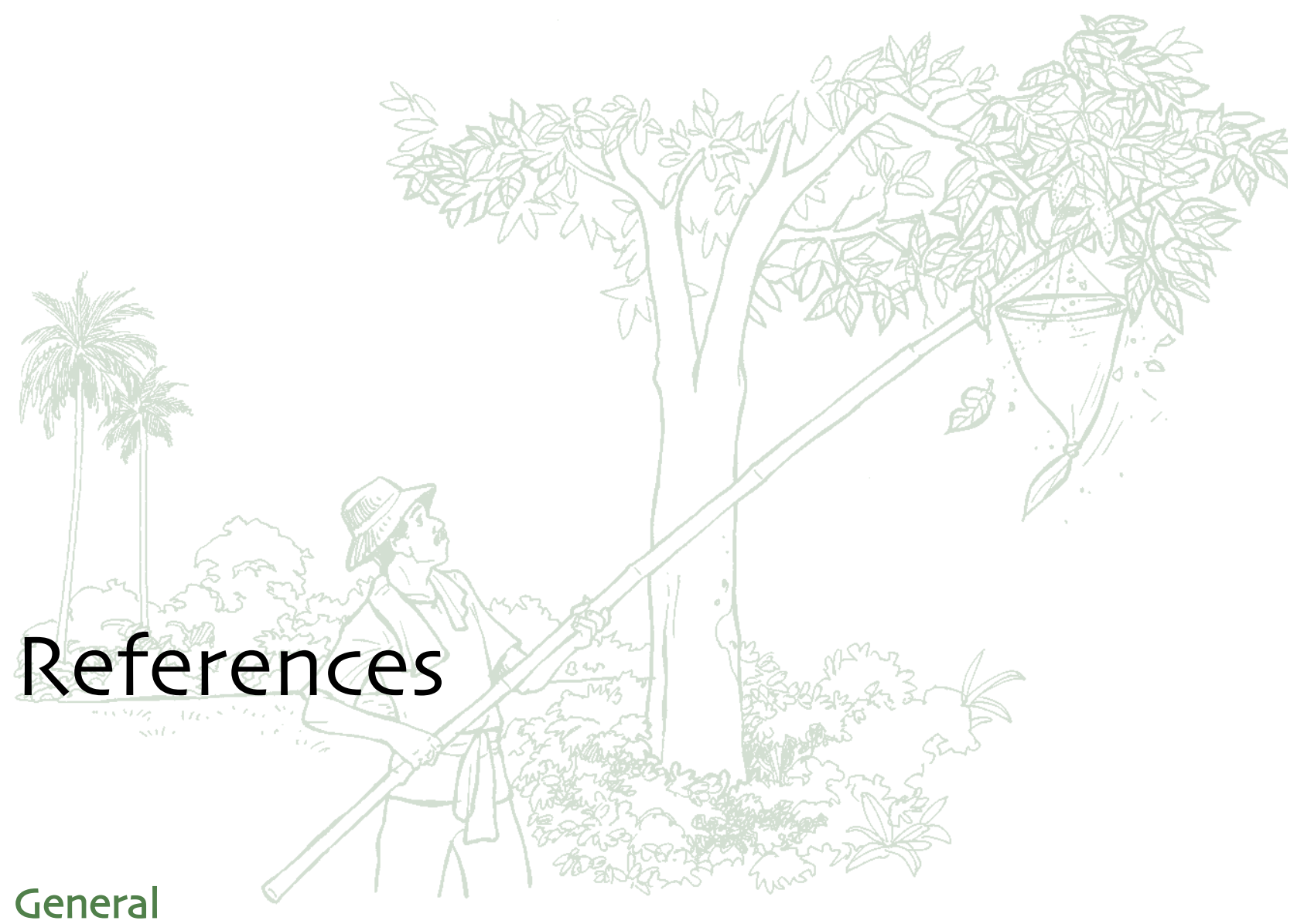

Belcher, B.M. and Schreckenberg, K. 2003. NTFP Commercialization: A Reality Check. Paper presented to the World Forestry Congress Side Event "Strengthening Global Partnerships to Advance Sustainable Development of Non-Wood Forest Products". Quebec City, Canada, 20 September 2003.

Belcher, B.M., Ruiz-Pérez, M. and Achdiawan, R. 2003. Global Patterns and Trends in NTFP Development. Paper presented to the international conference "Rural Livelihoods, Forests and Biodiversity". Bonn, Germany, 19-23 May 2003.

De Beer, J. (ed.) 1996 The Economic value of non-timber forest products in Southeast Asia. Netherlands Committee for the World Conservation Union (IUCN).

García-Fernández, C. 2001 Sistemas tradicionales de gestión del bosque tropical en Indonesia: Ecología y prácticas silviculturales. Facultad de Biologia, Universidad Complutense de Madrid, Madrid, Spain. 215p.

Mittelman, A.J., Lai, C.K., Byron, N., Michon, G. and Katz, E. 1997 Non-wood forest products outlook study for Asia and the Pacific: Towards 2010. FAO Asia-Pacific Forestry Sector Outlook Study. Working Paper Series, Working paper No. APFSOS/WP/28. Food and Agriculture Organization of the United Nations, Forest Policy and Planning Division, Rome/Regional Office for Asia and the Pacific, Bangkok, Thailand. 
Non-Timber Forest Products Research Centre 1999 Survey NTFP utilization in Bac Kan Province. Non-Timber Forest Products Research Centre, Hanoi.

NTFP.org Bulletin of the NTFP Exchange Programme in Southeast Asia. Voices from the Forest. www.ntfp.org/voices/voices6/contents6.html (May 2003).

Ruiz-Pérez, M. and Byron, N. (eds.) 1999 A methodology to analyze divergent case studies of nontimber forest products and their development potential. Forest Science 45(1): 1-14.

Wollenberg, E. and Ingles, A. 1998 Incomes from the forest - Methods for the development and conservation of forest products for local communities. Center for International Forestry Research, Bogor, Indonesia. 227p.

\section{Fruits/Seeds}

Aubertin, C. (forthcoming) Cardamom (Amomum spp.) in the Lao People's Democratic Republic: The hazardous future of an agroforest system product. In: Kusters, K. and Belcher, B. (eds.) Forthcoming 2004. Forest products, livelihoods and conservation: Case-studies of NTFP systems. Volume 3 - Asia. Center for International Forestry Research, Bogor, Indonesia.

Aubertin, C. (ed.), 1998 Actes du colloque 'Agroforesterie et produits forestiers', Institut de recherche pour le Développement (IRD), Uni. of Lao PDR Faculty of Agriculture and Forestry (FAF), Comitéde Coopération avec Laos (CCL). Ban Itou, province de Champassak, 121p.

Dury, S., Vilcosqui, L. and Mary, F. 1996 Durian trees (Durio zibethinus Murr.) in Javanese homegardens: Their importance in informal financial systems. Agroforestry Systems 33: 215-230.

Foppes, J. and Ketphanh, S. 1998 The use of non-timber forest products in Lao PDR. Paper presented at the workshop on Protected Area Management, Xishaungbanna, 3-8 November 1997. In: Actes du colloque 'Agroforesterie et produits forestiers', Institut de recherche pour le Développement (IRD), Uni. of Lao PDR Faculty of Agriculture and Forestry (FAF), Comitéde Coopération avec Laos (CCL). Ban Itou province de Champassak, 121p.

Gautam, K.H. (forthcoming) Lapsi (Choerospondias axillaris) emerging as a commercial non-timber forest product in the hills of Nepal. In: Kusters, K. and Belcher, B. (eds.) Forthcoming 2004. Forest products, livelihoods and conservation: Case-studies of NTFP systems. Volume 3 - Asia. Center for International Forestry Research, Bogor, Indonesia.

Gautam, K.H. 1997 The sweet and sour tale of lapsi - Domesticating and commercialising Choerospondias axillaris. Agroforestry Today 9(3): 13-16. 
Jackson, J.K. 1994 Manual of afforestation in Nepal. Forest Research and Survey Centre, Kathmandu.

Mitra, R. 1987 Spices in India: Their medicinal importance and therapeutic uses. Vivekananda Kendra Patrika. 16(1): 10-30.

Nair, T.K.R. and Kutty, M.G. (forthcoming) Cardamom (Elettaria cardamomum) in Kerala, India. In: Kusters, K. and Belcher, B. (eds.) Forthcoming 2004. Forest products, livelihoods and conservation: Casestudies of NTFP systems. Volume 3 - Asia. Center for International Forestry Research, Bogor, Indonesia.

Napier, I. and Robins, M. 1991 Forest seed and nursery practices in Nepal. Forestry Research Project Kathmandu. 139p.

Rai, N.D. (forthcoming) The socio-economic and ecological impact of Garcinia gummi-gutta fruit harvest in the Western Ghats, India. In: Kusters, K. and Belcher, B. (eds.) Forthcoming 2004. Forest products, livelihoods and conservation: Case-studies of NTFP systems. Volume 3 - Asia. Center for International Forestry Research, Bogor, Indonesia.

Spices Board 1997 Cardamom - Package of practices. Ministry of Commerce, Government of India, Cochin, India.

Spices Board 1996 Agmark Grade Specifications for Spices. Ministry of Commerce, Government of India, Cochin, India.

Vilcosqui, L. 1997 Le durian: Roi des fruits en Asie du Sud-Est. Fruits 52: 47-57.

\section{Mushrooms}

Chen, Y.L. (forthcoming) Song Rong (Tricholoma matsutake), a valuable forest mushroom from China: Consumption, development and sustainability. In: Kusters, K. and Belcher, B. (eds.) Forthcoming 2004. Forest products, livelihoods and conservation: Case-studies of NTFP systems. Volume 3 - Asia. Center for International Forestry Research, Bogor, Indonesia.

Chen, Y.L. 2002a Conservation and development of forest mushrooms: A case study on song rong (Tricholoma matsutake) from China. Chinese Forestry Science and Technology 1(2): 6-16.

Chen, Y.L. 2002b Cultivation techniques for European truffles (Tuber spp.). Edible Fungi of China 21(3): 7-9.

Chen, Y.L. 2000 Wild edible fungi for industry in China. Green Times 497: 2. 
Huang, N.L. 1993 Encyclopaedia of edible fungi of China. China Agriculture Publishing House, Beijing.

Ogawa, M. and Ito, I. 1989 Is it possible to cultivate Matsutake? Sou Shin Press, Tokyo.

Wang, Y., Hall, I.R. and Evans, L.A. 1997 Ectomycorrhizal fungi with edible fruiting bodies. Tricholoma matsutake and related fungi. Economic Botany 51(3): 311-327.

Youn, Y-C. (forthcoming) The Production of oak mushrooms (Lentinula edodes) as a source of farmers' income in the Republic of Korea: The Case of Cheongyang-Gun. In: Kusters, K. and Belcher, B. (eds.) Forthcoming 2004. Forest products, livelihoods and conservation: Case-studies of NTFP systems. Volume 3 - Asia. Centre for International Forestry Research, Bogor, Indonesia.

\section{Birds/Insects}

Césard, N. (forthcoming) Harvesting and commercialisation of kroto (Oecophylla smaragdina) in the Malingping area, West Java, Indonesia. In: Kusters, K. and Belcher, B. (eds.) Forthcoming 2004. Forest products, livelihoods and conservation: Case-studies of NTFP systems. Volume 3 - Asia. Center for International Forestry Research, Bogor, Indonesia.

De Jung, W. 2000 Micro-differences in local resource management: The case of honey in West Kalimantan, Indonesia. Human Ecology 28(4): 631-640.

Lau, A.S.M. and Melville, D.S. 1994 International trade in swiftlet nests with special reference to Hong Kong. Traffic International report (wildlife trade monitoring network), UK, 35P.

Mardiastuti, A. 1999 Breeding biology of the edible-nest swiftlets in Java. Media Konservasi I/2: 37-43.

Novelino, D. 1999 The ominous switch: From indigenous forest management to conservation - the case of the Batak on Palawan Island, Philippines. In: Colchester, M. and Erni, C. (eds.) Indigenous Peoples and Protected Areas in South and Southeast Asia, Document No. 97, International Working Group for Indigenous Affairs (IWGIA), Copenhagen.

\section{Shoots/Culms/Stems}

Belcher, B.M, Ndan Imang, R. and Achdiawan, R. In press. Rattan, rubber or oil palm: Cultural and financial considerations for farmers in Kalimantan. Journal of Economic Botany.

Belcher, B.M. 2001 Rattan cultivation and livelihoods: The changing scenario in Kalimantan. Unasylva 205(52): 27-34. 
de Jong, W., Rohadi, D., Belcher, B., Mustikasari, R. and Levang, P. 2003 The political ecology of forest products in Indonesia: A history of changing adversaries. In: Tuck-Po, L., de Jong, W. and Abe, K. (eds.) The political ecology of forests in Southeast Asia. Kyoto University Press.

Feaw, T.C., 1992 The history of rattan cultivation. Malayan Forest Record No. 35, P 51-55.

Godoy, R.A. 1990 The economics of traditional rattan cultivation. Agroforestry System 12: 163-172.

Haury, D. and Saragih, B. 1996 Processing and marketing rattan. Ministry of Forestry in Cooperation with Deutsche Gesellschaft für Technische Zusammenarbeit (GTZ). Fraser Sustainable Forest Management Plan (SFMP) Document No. 6a.

Maoyi, F. and Jianghua, X. (forthcoming) Bamboo production and marketing in Anji County, China. In: Kusters, K. and Belcher, B. (eds.) Forthcoming 2004. Forest products, livelihoods and conservation: Case-studies of NTFP systems. Volume 3 - Asia. Centre for International Forestry Research, Bogor, Indonesia.

Maoyi, F. and Jianghua, X. 2000 Cultivation and utilisation of bamboo. The Research Institute of Subtropical Forestry. China Forestry Publishing House, Beijing.

Mayer, J., 1989 Rattan cultivation, family economy and land use: A case from Pasir, East Kalimantan. German Forestry Group (GFG) Report No. 13, P. 39-53.

Palis, H.G. (forthcoming) Rattan (Calamus spp.) extraction in the Philippines: The case of Manggapin and Kalakwasan watersheds, Palawan. In: Kusters, K. and Belcher, B. (eds.) Forthcoming 2004. Forest products, livelihoods and conservation: Case-studies of NTFP systems. Volume 3 - Asia. Center for International Forestry Research, Bogor, Indonesia.

Pambudhi, F., Belcher, B., Levang, P. and Dewi, S. (forthcoming) Rattan (Calamus spp.) gardens of Kalimantan: Resilience and evolution in a managed non-timber forest product system. In: Kusters, K. and Belcher, B. (eds.) Forthcoming 2004. Forest products, livelihoods and conservation: Casestudies of NTFP systems. Volume 3 - Asia. Center for International Forestry Research, Bogor, Indonesia.

Peluso, N.L. 1992 The rattan trade in East Kalimantan, Indonesia. In: Nepstad, D.C., and Schartzman, S. (eds.) Non timber products from tropical forest: Evaluation of a conservation and development strategy. Vol. 9, Advances in economic botany, The New York Botanical Gardens, Bronx, New York. p. 115-127.

Price, M. and Butt, N. (eds.) 2000 Forests in Sustainable Mountain Development. Mountain Regions \& Conservation Programme, Environmental Change Institute, University of Oxford, UK, 624P. 
Qisheng, Z. and Weishan, S. 1997 Chinese bamboo handicrafts. China Forestry Publishing House, Beijing, 124P.

Ruiz-Pérez, M., Belcher, B.M., Maoyi, F. and Yang, X. 2003 Forestry, poverty and rural development: Perspectives from the bamboo sub-sector. In: Hyde, W.F., Belcher, B.M. and Xu, J. (eds.) China's forests: Global lessons from market reforms, p. 151-176. Resources for the Future Press.

Ruiz-Pérez, M., Maoyi, F., Belcher, B. and Xiaosheng, Y. 2000 Case study: The potential of bamboo resources in mountainous China. Forests in sustainable mountain development: a state of knowledge report for 2000. International Union of Forest Research Organizations (IUFRO) Research Series No. 5. CABI Publishing, Wallingford, 318p.

Ruiz-Pérez, M., Maoyi, F., Xiaosheng, Y. and Belcher, B. 2001 Bamboo forestry in China: Toward environmentally friendly expansion. Forestry 99(7): 14-20.

Ruiz-Pérez, M., Maogong, Z., Belcher, B.M., Chen, X., Maoyi, F. and Jinzhong, X. 1999 The role of bamboo in rural development: The case of Anji County, Zhejiang, China. World Development. 27(1): 101-114.

Sadikin N.P. and Nyongka, F. 2001 Rattan for life. The rattan cultivation practices of the Dayak Benuaq of Kalimantan, Indonesia: An information manual. SHK Kaltim, NTFP-Exchange Programme, Studio Driya Media-Bandung.

\section{Leaves/Wood/Bark}

Aubertin, C. (forthcoming) Paper mulberry, Broussonetia papyrifera, in the Lao People's Democratic Republic: A successful example of forest product domestication. In: Kusters, K. and Belcher, B. (eds.) Forthcoming 2004. Forest products, livelihoods and conservation: Case-studies of NTFP systems. Volume 3 - Asia. Center for International Forestry Research, Bogor, Indonesia.

Aubertin, C. 2002 Les produits forestiers non ligneux: Un outil de la rhetorique du developpement durable. Natures, Sciences Societes 10(2): 39-46.

Barden, A., Anak, N.A., Mulliken, T. and Song, M. 2000 The heart of the matter: Agarwood use and trade and CITES implementation for Aquilaria malaccensis. Traffic International report (wildlife trade monitoring network), UK. [online: www.traffic.org/news/agarwood.pdf]

Boaz, A. (forthcoming) Case study of tendu leaves (Diospyros melanoxylon) in Harda District, Madhya Pradesh, India. In: Kusters, K. and Belcher, B. (eds.) Forthcoming 2004. Forest products, livelihoods and conservation: Case-studies of NTFP systems. Volume 3 - Asia. Center for International Forestry Research, Bogor, Indonesia. 
Boaz, O. 2002 Role of NTFP in tribal economy in Madhya Pradesh with particular reference to Harda district. Ph.D. Thesis, Barkatullah University, Bhopal, India.

Coppen, J.J.W. 1995 Gums, resins and latexes of plant origin. Non Wood Forest Products (6). Food and Agriculture Organization of the United Nations, Rome.

Foppes, J., Sengsavanh, V., Victor, M., Soydara, V. and Ketphanh, S. (forthcoming) The marketing of tout tiang, a non-timber forest product from the northern provinces of Lao PDR. In: Kusters, K. and Belcher, B. (eds.) Forthcoming 2004. Forest products, livelihoods and conservation: Case-studies of NTFP systems. Volume 3 - Asia. Center for International Forestry Research, Bogor, Indonesia.

Gupta, T. and Guleria, A. 1982 NWFP in India, Oxford \& IBH Co., New Delhi, India.

Mandang 1982 Wood species for wood carving in Bali. Paper to Consultancy Meeting on Ebony. 2930 September 1982. Lembaga Penelitian Hasil Hutan, Bogor, Indonesia.

Rohadi, D., Permadi, P. and Hidayat, S. (forthcoming) The development of the woodcarving industry and the cultivation of Paraserianthes falcataria in Bali, Indonesia. In: Kusters, K. and Belcher, B. (eds.) Forthcoming 2004. Forest products, livelihoods and conservation: Case-studies of NTFP systems. Volume 3 - Asia. Center for International Forestry Research, Bogor, Indonesia.

Soehartono, T. 2002 The gaharu trade in Indonesia: Is it sustainable? Economic Botany 56(3): 271-284.

Wollenberg, E. 2003 Boundary keeping and access to gaharu among Kenyah forest users. Environment and Planning 35(6): 1007-1023.

Yamada, I. 1996 Aloeswood forest and the maritime world. Journal of Southeast Asian Studies 33: 181.

\section{Resin/Oil}

de Foresta, H., Michon, G., Kusworo, A. and Levang, P. (forthcoming) Damar agroforests in Sumatra, Indonesia: Domestication of a forest ecosystem through domestication of dipterocarps for resin production. In: Kusters, K. and Belcher, B. (eds.) Forthcoming 2004. Forest products, livelihoods and conservation: Case-studies of NTFP systems. Volume 3 - Asia. Center for International Forestry Research, Bogor, Indonesia.

García-Fernández, C. (forthcoming) Benzoin, a resin produced by Styrax trees in North Sumatra Province, Indonesia. In: Kusters, K. and Belcher, B. (eds.) Forthcoming 2004. Forest products, livelihoods and conservation: Case-studies of NTFP systems. Volume 3 - Asia. Center for International Forestry Research, Bogor, Indonesia. 
García-Fernández, C., Casado, M.A. and Ruiz-Pérez, M. 2003 Benzoin gardens in North Sumatra, Indonesia: Effects of management on tree diversity. Conservation Biology 17: 829-836.

Goloubinoff, M. 1998 Senteurs de miel et d'encens: Le benjoin a Java. In: Guillot, C. (ed.) Histoire de barus: Le site de Lobu Tua. Etudes de documents. Cahier d'Archipel, Paris, p. 265-80.

Hoesen, D.S.H. 2000 Styrax L. Plants producing exudates. In: Boer, E. and Ella, A. (eds.) Plant resources of South-East Asia (PROSEA). No. 18, Backhuys Publishers, Leiden, Netherlands, p. 112-119.

Katz, E., García-Fernández, C. and Goloubinoff, M. 2002 Sumatra benzoin. In: Shanley, P., Pierce, A.R., Laird, S. and Guillén, A. (eds.), Tapping the Green Market. Center for International Forestry Research (CIFOR) and Earthscan, London.

Michon, G., de Foresta, H., Kusworo, A. and Levang, P. 2000 The damar agro-forests of Krum, Indonesia: Justice for forest farmers. In: Zerner, C. (ed.) People, plants and justice. The politics of nature conservation, p. 159-203. Columbia University Press.

Rohadi, D., Maryani, R., Widyana, M. and Azhar, I. (forthcoming) A Case study of the productionto-consumption system of sandalwood (Santalum album) in South Central Timor, Indonesia. In: Kusters, K. and Belcher, B. (eds.) Forthcoming 2004. Forest products, livelihoods and conservation: Case-studies of NTFP systems. Volume 3 - Asia. Center for International Forestry Research, Bogor, Indonesia.

Rohadi, D., Maryani, R., Belcher, B., Ruiz-Pérez, M. and Widyana, M. 2000 Can sandalwood in East Nusa Tenggara survive? Lessons from the policy impact on resource sustainability. Sandalwood Research Newsletter 10: 3-6. 


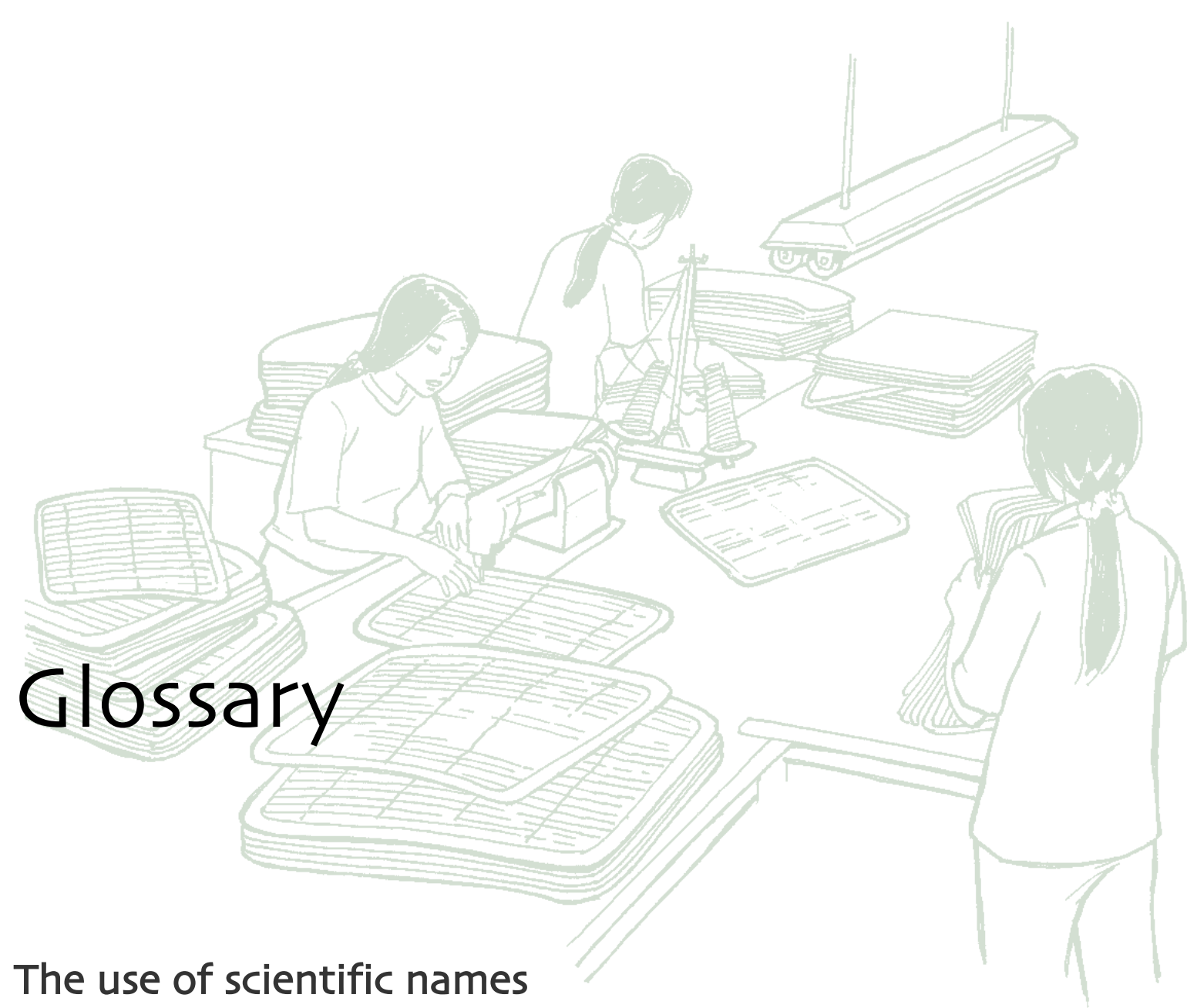

At the start of each case in this volume, you will have noticed the scientific names of the different forest plants (and animals) that are profiled. Biological classification helps us to understand the natural world and structure our knowledge. It enables people to identify and record species, providing a universal language of communication and serving as an important tool in nature conservation.

Each different species has a scientific name, which is a Latin binomial (or two-part name). This consists of a genus, followed by a species name and the name or initials of the person (or people) that published the first scientific description of that species (e.g. Shorea javanica Koord. \& Valet.). When it comes to naming plants, the system of 'botanical nomenclature' is used to distinguish and identify different types of plants. There are a number of reasons for this:

\section{Universal Recognition}

A plant can be identified in any country around the world using its botanical name-overcoming the barrier of different languages. 


\section{Relationships}

Plant relationships can easily be determined by examining the botanical classification.

\section{Identification}

Common names are problematic and vary between districts. For instance, the name 'durian' could refer to any of the 28 species of Durio. A botanical name points to one specific type of plant.

\section{Origins}

The origins of the plant can be established by looking at the name. For example, indicating if it is a hybrid (i.e. the offspring of two different plant species or varieties).

\section{Genus}

Genus names are always written in italics and begin with a capital letter (e.g. Durio). They may be derived from the name of a famous botanist or classical Latin names relating to the relevant plant. Alternatively, they may be Latinised forms of more common names, drawing on languages like French or English.

\section{Species}

This level consists of a general epithet (genus name) and a specific epithet (species name) (e.g. Durio zibethinus). The species name distinguishes exactly which plant is being referred to within a given genus. Species names are always written in italics, using lower case letters, and are usually descriptive. For example, they may provide clues to a plant's origins (e.g. Shorea javanica = from Java), describe the plant (e.g. Tricholoma matsutake. In Japanese, the word 'matsutake' comes from matsu = pine and take = mushroom and in this case, describes a mushroom that grows in coniferous forests*), or signify that a particular plant is named after someone (if the species name has the suffix -i or -ii. e.g. clarkei = after (larke).

\section{Subspecies}

Sometimes within a species there is significant variation but not enough to assign another species. In this instance, the classification 'subspecies' is used. Subspecies names are always written in italics, using lower case letters, and like species names, are often descriptive (e.g. Shorea macroptera ssp. baillonii).

\section{Varietas (Variety)}

Sometimes within a species (or subspecies) there is moderate variation, requiring the more subtle classification of 'varietas' or 'variety'. Varietas names are always written entirely in lower case italics and again, are often descriptive (e.g. Phyllostachys heterocycla var. pubescens). 
Agroforestry - Diverse farming systems whereby trees are integrated with crops to increase production and also, social and environmental benefits.

Annual Plant - A plant in which the life cycle is completed in a single growing season or year from germination.

Biodiversity - Biological diversity. The variety of life in all its forms, levels and combinations including ecosystem diversity, species diversity, and genetic diversity.

Canes - The long, hollow or pithy, jointed stems of certain plants like rattan, bamboo and sugar cane.

Canopy - The upper layer of tree crown in a forest, providing a cover of filtered light for understorey trees and plants.

CITES - The Convention on International Trade in Endangered Species of Wild Fauna and Flora. This international agreement between Governments aims to ensure that international trade in wild animals and plants does not threaten their survival. CITES works by subjecting international trade in specimens of selected species to certain controls. Authorisation through a licensing system is required for species covered by the Convention. These species are listed in three Appendices according to the degree of protection needed.

Cloned - Genetically identical organisms. In plant propagation, cloned plants may be reproduced asexually from the buds or cuttings of a particular plant with desirable qualities, resulting in offspring that are genetically identical to the 'parent' plant.

Commercialisation - The process by which a product is made more profitable or is developed further for the purpose of sale.

Coniferous Forests/Conifers - Forests composed mainly of evergreen, cone bearing trees (such as pine, fir, spruce or larch trees - know as 'conifers').

Coppices/Coppicing - Shoots arising from woody stumps or the underground roots of parent plants.

Culms - Stalks or stems of grasses and sedges (such as bamboo).

Cultivar - A variety of plant that has been produced only under cultivation.

Disturbed Forest - Forest altered by natural or human activities. 
Domesticated/Domestication - The process by which formerly wild plants or animals are retained or integrated into farmland systems or home gardens, sometimes involving selective breeding over many generations to improve desirable characteristics for human benefit.

Ecosystem - A community of living organisms interacting with each other and the physical environment in which they live.

Evergreen - Trees and shrubs that retain living leaves throughout the year. The leaves of the past season are not shed until the new foliage has been completely formed. This contrasts with deciduous plants, which lose their leaves during a certain season.

Fallow - Formerly planted land that is left uncultivated or unseeded for one or more seasons.

Genetic - Relating to the genetic code: the arrangement of chromosomes, genes and deoxyribonucleic acid (or DNA) found within living cells. This code carries the hereditary material of living organisms and is passed on from parents to offspring.

Genus - A group of closely related species that have many characteristics in common.

Gunny Sacks - Sacks commonly made out of coarse jute or hemp cloth.

Habitat - The environment of an organism or species; the place where it is usually found living.

Heartwood - Non-living and commonly dark coloured wood within the centre of a tree, in which no water or nutrients are transported. The heartwood is surrounded by sapwood (the outer part of the stem or trunk where water and nutrient transport takes place).

Herbaceous - Non woody plants; herb-like.

Host Tree - A tree from which a parasite (or other organism, like a fungus or insect) obtains nutrition and/or lives on. Or, a tree which another plant uses for structural support (e.g. as in the case of rattan).

Litter - The rich and fertile layer of organic matter lining the forest floor, containing mainly decomposing leaves and wood, along with other biological debris and micro-organisms.

Monoculture - The use of land for growing only one type of crop.

Native - Originating in or characterising a particular region or country, indigenous to the area. 
Organic/Organically Grown - Grown using natural methods and produced without the aid of chemicals (artificial fertilisers, pesticides, etc).

Perennial Plant - A plant in which the life cycle spans more than 2 years.

Primary Forest - Mature, old growth forest.

Propagate - The process of breeding or assisting plants, animals, etc to naturally reproduce from parent stock. Or, the process of growing new plants from seed or cuttings.

Rhizome - A thick horizontal stem, usually growing underground, which sends out shoots above ground and roots below.

Secondary Forest - Forest regrowth following significant disturbance of the original vegetation. The new growth often differs in forest structure and species composition compared to primary forests.

Shifting Cultivation - A cyclical agricultural system, involving the clearing of land, usually with the assistance of fire, followed by alternating periods of cultivation and fallow. This term does not mean that the people themselves are 'shifting' or 'semi-nomadic' - most shifting cultivators live in relatively permanent settlements.

Slash and burn - A method of clearing and preparing land, common amongst shifting cultivators, which involves cutting and burning the existing vegetation.

Sustainability/Sustainable Harvesting or Management - The gathering of plants or plant products in a way that does not jeopardise the reproductive capacity or regenerative potential of a particular species within a given area.

Swidden Fields - Fields that have previously been set on fire to clear and prepare them for cultivation as part of an agricultural system known as 'shifting cultivation'.

Understorey Layer - Plants growing under the canopy of forest trees. 


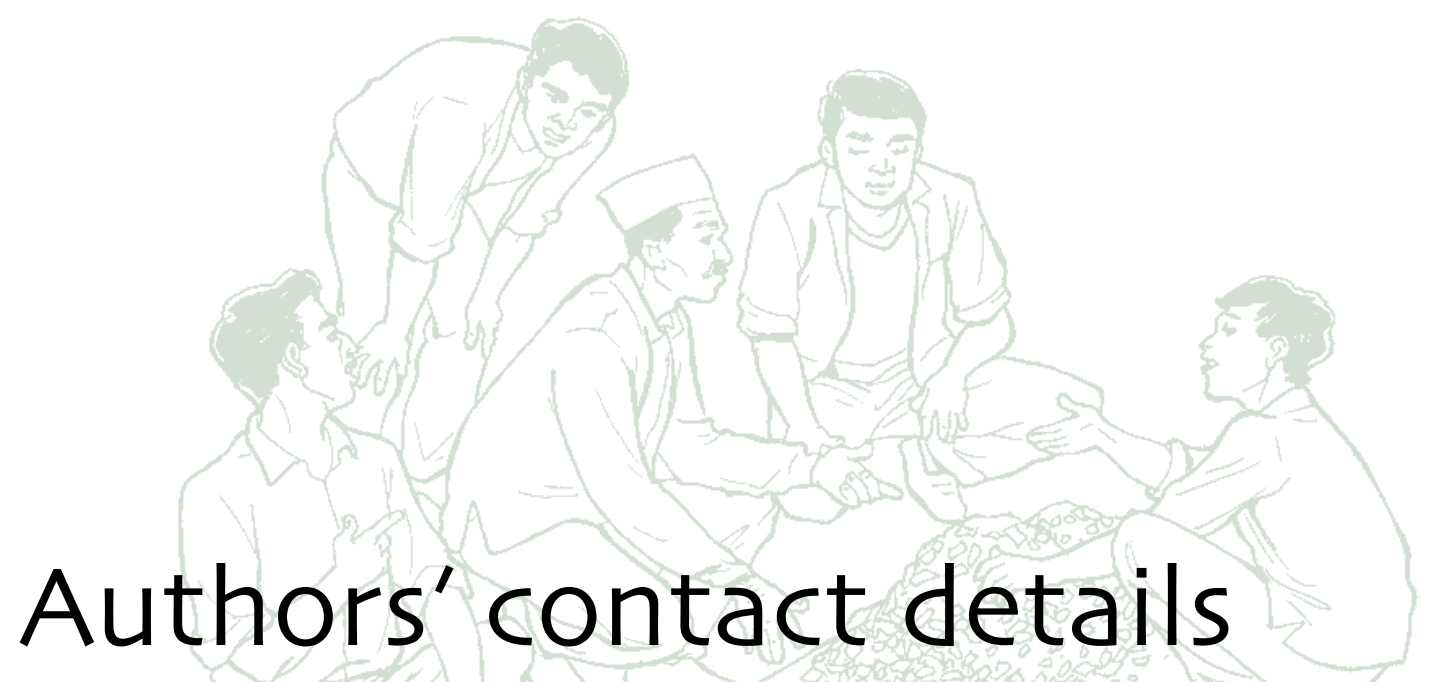

\section{An Van Bay}

Non-Timber Forest Product Research Centre

No 9 Chuong Duong Do, Hoan kiem district

Hanoi, Vietnam

bay1135@hn.vnn.vn

Arvind A. Boaz

Chhattisgarh Forest Development Corporation

D-252-253, Sector-5, Devendra Nagar

Raipur (Chhattisgarh) India - 492004

Draboaz@sancharnet.in

\section{Brian Belcher}

Center for International Forestry Research

Jalan CIFOR, Situ Gede, Sindang Barang

Bogor Barat 16680 - Indonesia

b.belcher@cgiar.org 


\section{Carmen García Fernández}

Escritorio do CIFOR

Embrapa-CPATU

Trav. Enéas Pinheiro S/N

66.905-780 Belem, Para, Brazil

c.garcia@cgiar.org

\section{Catherine Aubertin}

Centre IRD d'Orléans

Institut de Recherche pour le Développement

Technoparc, 5 rue du Carbone

45072 Orleans cédex 2, France

Catherine.Aubertin@orleans.ird.fr

\section{Citlalli López}

Center for International Forestry Research

Jalan CIFOR, Situ Gede, Sindang Barang

Bogor Barat 16680 - Indonesia

ci.lopez@cgiar.org

\section{Dede Rohadi}

Forestry Research Institute of Sulawesi, Jalan Perintis Kemerdekaan Km. 16.5

Makassar, Indonesia

drohadi@indo.net.id

\section{Esther Katz}

Centre IRD d'Orléans

Institut de Recherche pour le Développement

Technoparc, 5 rue du Carbone

45072 Orleans cédex 2, France

Esther.Katz@orleans.ird.fr

\section{Fadjar Pambudhi}

Center for Social Forestry, Universitas Mulawarman

Gd. Pasca Sarjana Magister Kehutanan-Kampus

Gn. Kelua. Jl. Ki Hajar Deantara 7

Samarinda, Kalimantan Timur 75123, Indonesia

csf@samarinda.org 


\section{Fu Maoyi}

Research Institute of Subtropical Forestry, Chinese Academy of Forestry 73\# Daqiao RD, Fuyang 311400,

Zhejiang, P. R. China.

fmy@fy.hz.zj.cn

\section{Geneviève Michon}

IRD Institut de Recherche pour le Développement

Current address:

Centre ENGREF (Ecole Nationale du Génie Rural, des Eaux et des Forêts) Montpellier, 648, Rue Jean-Franşois Breton

BP. 44494 34093, Montpellier, Cedex o5 France genevieve.michon@mpl.ird.fr

\section{Honorato G. Palis}

Ecosystem Research Development Bureau (ERDB),

Laguna 4031, The Philippines

hgpalis@lgn.pworld.net.ph

\section{Hubert de Foresta}

IRD Institut de Recherche pour le Développement Current address:

Centre ENGREF (Ecole Nationale du Génie Rural, des Eaux et des Forêts) Montpellier, 648, Rue Jean-Fransois Breton

BP. 44494

34093, Montpellier, Cedex 05 France

foresta@engref.fr

\section{*Irdez Azhar}

World Wildlife Fund, Wallacea Bali

Jalan Hayam Wuruk 179

Denpasar 80235, Bali, Indonesia

* Affiliated with the Center for International Forestry Research at the time of the study

iazhar@wallacea.wwf.or.id or irdez2001@yahoo.com 
Jenne de Beer

NTFP Exchange Programme South \& Southeast Asia (EP)

c/O UMFI

18 Marunong Street

Barangay Central

Diliman

Quezon City 100, The Philippines

mularia@hotmail.com

\section{Joost Foppes}

SNV-Forest Research Center

P.O. Box 345

Vientiane, Lao PDR

jfoppes@loxinfo.co.th

Krishna H. Gautam

Nepal Forest Service

Currently: JSPS Postdoctoral Fellow

Graduate School of Environmental Earth Science

Hokkaido University

Sapporo, 060-0810, Japan

khgautam@ees.hokudai.ac.jp

\section{Govindan Kutty}

Sylva cons

T.M. 16/417, Aiswarya

Kuttimakkool Road

Tellicherry, Kerala India

cnn_gkutty@sancharnet.in

g_kutty@hotmail.com

\section{Made Widyana}

Forestry Research Institute of Bali and Nusa Tenggara Jalan Untung Suropati No. 7

P.O. Box 67

Kupang, Indonesia

bpkk@kupang.wasantara.net.id 
Marina Goloubinoff

Rumpung Bambu

Jalan Bhayangkara I no 20

RT 5/III Sindang Barang

Bogor Barat 16003

Bogor, Indonesia

mgoloubinoff@hotmail.com

Nicolas Césard

IRD-Indonésie

Wisma Anugraha

Jalan Taman 32 B, Jakarta 12730

Indonesia

ncesard@wanadoo.fr

\section{*Nitin Rai}

1743, 9th Cross, 17th Main

J.P. Nagar II Phase

Bangalore 560078, India

*Affiliated with the Department of Biology,

Pennsylvania State University (USA) at the time of the study

nitinrai@vsnl.com

\section{Patricia Shanley}

Center for International Forestry Research

Jalan CIFOR, Situ Gede, Sindang Barang

Bogor Barat 16680 - Indonesia

p.shanley@cgiar.org

\section{Pipin Permadi}

Forest Products Research and Development Center Jalan Gunung Batu No. 5,

Bogor, Indonesia

permadi@indo.net.id

\section{Renni Samsoedin Hoshi}

Lowar Noda 102, 3 Crome 4-35, Noda-cho

Fukushima-shi, Fukushima-ken, 960-8055

Japan 


\section{Retno Maryani}

Center for Social and Economic Research on Forestry Jalan. Gunung Batu No. 5

P.O. Box. 16610

Bogor, Indonesia

retnomaryani@hotmail.com

T.K. Raghavan Nair

Sylva cons

Vijaya Bhavan

Olai, Kollam-691009

Kerala, India

sylvacon@vsnl.com

\section{Yeo-Chang Youn}

Seoul National University

School of Forest Resources

Silim-dong San 56-1, Gwanak-ku, 151-742

Seoul, South Korea

Fax: $+82-2-873-3560$

youn@snu.ac.kr

\section{Ying Long Chen}

School of Biological Sciences and Biotechnology

Murdoch University

South St., WA 6150 Australia

y.chen@murdoch.edu.au 


\title{
Source material used for the illustrations
}

\author{
Front cover \\ Garcinia gummi-gutta, based on a photo by Nitin Rai \\ Boy with durian, based on a photo by Geneviève Michon \\ Page v \\ Based on a photo by Krishna H. Gautam \\ Page vi \\ Page viii \\ Page $x$ \\ Page 5 \\ Page 6 \\ Page 7 \\ Page 9 \\ Page 11 \\ Page 12 \\ Page 13 \\ Page 14 \\ Page 15 \\ Page 16 \\ Page 17 \\ Page 18 \\ Page 19 \\ Page 21 \\ Page 23 \\ Page 24 \\ Page 25 \\ Page 27 \\ Page 28 \\ Page 29 \\ Agathis dammara, drawn from a botanical specimen, Bogor Herbarium \\ Based on a photo by M. Govindan Kutty \\ Based on a photo by Geneviève Michon \\ Garcinia gummi-gutta, based on a photo by Nitin Rai \\ Based on a photo by Sujan Chattergee from the birds of Kolkata website \\ (http://www.kolkatabirds.com/mammals/giantsquirrelmaxima28.jpg) \\ Right and left: Based on photos by Nitin Rai \\ Choerospondias axillaris, drawn from botanical specimen, Bogor Herbarium \\ Based on a photo by Krishna H. Gautam \\ Based on a photo by Krishna H. Gautam \\ Elettaria cardamomum, drawn from a botanical specimen, Bogor Herbarium \\ Based on a photo by $M$. Govindan Kutty \\ Right and left: Based on photos by T.K. Raghavan Nair \\ Based on a photo by $M$. Govindan Kutty \\ Amomum villosum, based on photos by Catherine Aubertin and Joost Foppes \\ Based on a photo by Joost Foppes \\ Based on a photo by Joost Foppes \\ Durio zibethinus, drawn from a living sample \\ Based on a photo by Geneviève Michon \\ Based on a photo by Nicolas Césard \\ Tricholoma matsutake, based on photos by Ying Long Chen \\ Based on photos by Ying Long Chen \\ Right and left: Based on photos by Ying Long Chen \\ Lentinula edodes, based on a Hidden Forest Designs photo from the Hidden Forest (Forest \\ Fungi) website (http://www.hiddenforest.co.nz/fungi/index.htm) \\ Page 31 \\ Page 32 \\ Page 33 \\ Page 36 \\ Based on a photo by Yeo-Chang Youn \\ Based on a photo by Yeo-Chang Youn \\ Collocalia maxima, based on photos by Marina Goloubinoff \\ Based on sketches by Marina Goloubinoff \\ Page 37 \\ Page 39 \\ Page 40 \\ Page 41 \\ Page 42 \\ Oecophylla smaragdina, based on photos by Nicolas Césard \\ Top and bottom: Based on photos by Nicolas Césard \\ Right and left: Based on photos by Nicolas Césard \\ Apis dorsata, based on photos by Ravi Prabhu \\ Based on photos by Yani Saloh
}


Page 45

Page 48

Page 50

Page 51

Page 52

Page 54

Page 56

Page 57

Page 59

Page 60

Page 61

Page 62

Page 63

Page 64

Page 65

Page 66

Page 67

Page 69

Page 71

Page 73

Page 75

Page 76

Page 77

Page 78

Page 79

Page 80

Page 81

Page 84

Page 85

Page 86

Page 87

Page 88

Page 89

Page 90

Page 91

Page 93

Page 93

Page 104

Page 109

Back cover
Phyllostachys heterocycla, based on a botanical illustration in Reforestation technology of main Chinese tree species published by the Chinese Forestry Publishing House in Beijing, Jan. 1981

Based on a photo by Koen Kusters

Based on a photo by Koen Kusters

Calamus caesius, drawn from a botanical specimen, Bogor Herbarium

Calamus caesius, drawn from a botanical specimen, Bogor Herbarium

Right and left: Based on photos by Brian Belcher

Right and left: Based on photos by Geneviève Michon

Diospyros melanoxylon, drawn from a botanical specimen, Bogor Herbarium

Right and left: Based on photos by Arvind A. Boaz

Based on photos by Arvind A. Boaz

Broussonetia papyrifera, based on a photo by Catherine Aubertin

Based on a photo from the Forcap Project

Top and bottom: Based on photos by Catherine Aubertin

Based on a photo by Catherine Aubertin

Aquilaria malaccensis, drawn from a botanical specimen, Bogor Herbarium

Based on a video by Marina Goloubinoff

Based on a photo by Christophe Khun

Debregsia longifolia, drawn from a botanical specimen, Bogor Herbarium

Based on a photo by Joost Foppes

Paraserianthes falcataria, drawn from a botanical specimen, Bogor Herbarium

Based on photos by Pipin Permadi

Based on photos by Pipin Permadi

Styrax paralleloneurum, drawn from a botanical specimen, Bogor Herbarium

Based on sketches by Carmen García Fernadez

Based on photos by Geneviève Michon

Based on photos by Marina Goloubinoff

Santalum album, drawn from a botanical specimen, Bogor Herbarium

Based on photos by Brian Belcher

Shorea javanica, drawn from a botanical specimen, Bogor Herbarium

Based on photos by Geneviève Michon

Based on a photo by Hubert de Foresta

Based on photos by Hubert de Foresta

Based on a photo by Catherine Aubertin

Durio zibethinus, drawn from a living sample

Garcinia gummi-gutta, based on a photo by Nitin Rai

Based on photos by M. Govindan Kutty

Based on photos by Koen Kusters

Based on a photo by Nicolas Césard

Based on photos by Brian Belcher

Based on photos by Marina Goloubinoff

Agathis dammara, drawn from a botanical specimen, Bogor Herbarium 
The Center for International Forestry Research (CIFOR) was established in 1993 as part of the Consultative Group on International Agricultural Research (CGIAR) in response to global concerns about the social, environmental and economic consequences of forest loss and degradation. CIFOR research produces knowledge and methods needed to improve the well-being of forestdependent people and to help tropical countries manage their forests wisely for sustained benefits. This research is done in more than two dozen countries, in partnership with numerous partners. Since it was founded, CIFOR has also played a central role in influencing global and national forestry policies.

\section{Donors}

The Center for International Forestry Research (CIFOR) receives its major funding from governments, international development organizations, private foundations and regional organizations. In 2002, CIFOR received financial support from the African Timber Organization, Aracruz Celul ose SA - Brazil, Asian Development Bank, Australia, Belgium, Brazil, Canada, China, Conservation International Foundation, Denmark, European Commission, Finland, Food and Agriculture Organization of the United Nations (FAO), Ford Foundation, France, German Agency for Technical Cooperation (GTZ), German Federal Ministry for Economic Cooperation and Development (BMZ), Indonesia, International Development Research Centre (IDRC), International Tropical Timber Organization (ITTO), J apan, Korea, MacArthur Foundation, Netherlands, Norway, Peruvian Institute for Natural Renewable Resources (INRENA), Philippines, PI Environmental Consulting, Secretariat of the Convention on Biological Diversity, Sweden, Switzerland, The Overbrook Foundation, Tropical Forest Foundation, USA, United Kingdom, United Nations Environment Programme, United States Forest Service, United States National Oceanic and Atmospheric Administration, World Bank, World Conservation Union (IUCN), World Resources Institute and World Wide Fund for Nature (WWF). 


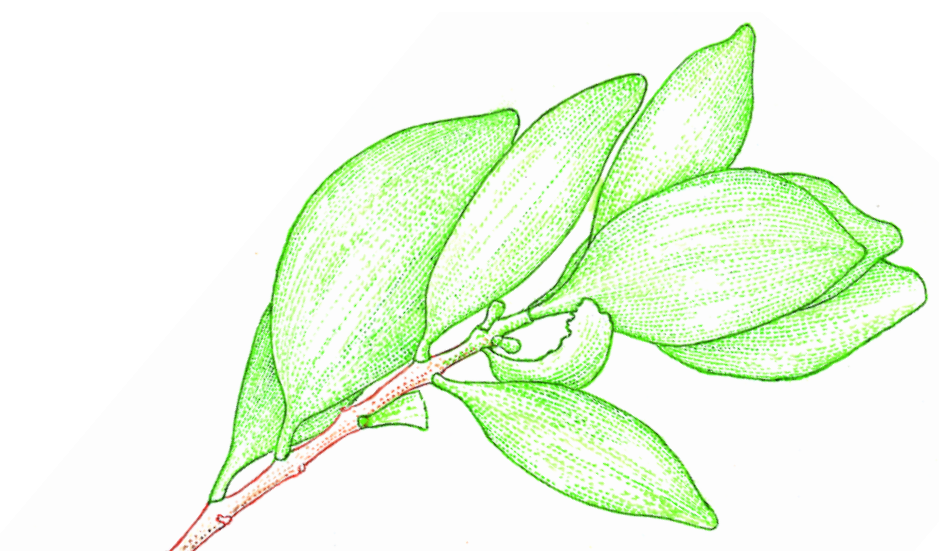

The richness of Asia's forests is reflected in the manifold products that are part of our daily lives. This publication, apart from being entertaining to read, may help you as a demanding consumer, to make more informed choices while shopping around next time.

Jenne de Beer

NTFP Exchange Programme South and Southeast Asia
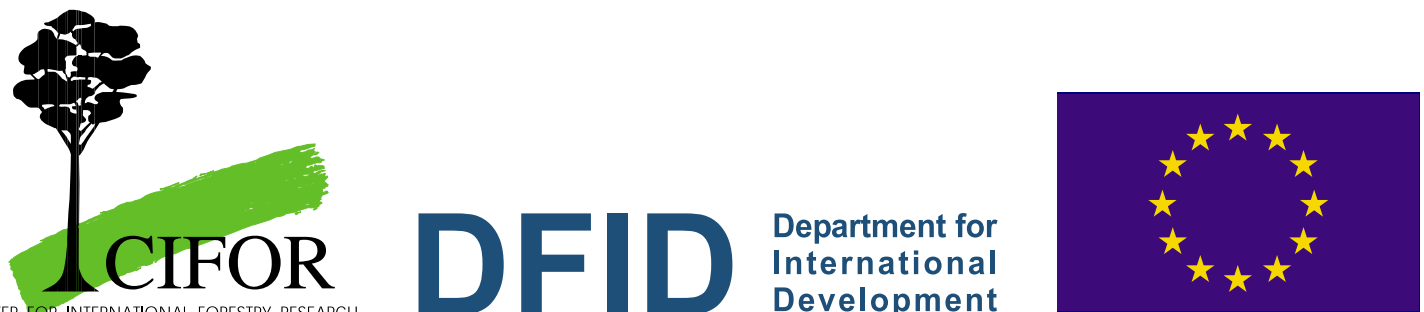